\title{
From the National to the Global: The Transformation of the Royal Bank of Canada, 1864-2014
}

\section{by}

Joel Zackary Garrod

A thesis submitted to the Faculty of Graduate and Postdoctoral Affairs in partial fulfillment of the requirements for the degree of

\author{
Doctor of Philosophy \\ in
}

Sociology

Carleton University

Ottawa, Ontario

(C) 2018, Joel Zackary Garrod 


\begin{abstract}
Many scholars today treat globalization as a new form of imperialism, in which the global political economy remains constituted by competing national capitals and their respective nation-states. This view is shared by many Canadian political economists who, carrying on a longstanding debate, continue to argue that Canada should be understood as either a secondary imperialist power or a dependency of the American empire. In this dissertation, I argue that contemporary theories of imperialism and dependency neglect a number of qualitative changes to the global political economy over the last 40 years that challenge the conceptual framework on which they are based. Through a comparativehistorical analysis of the changing assemblages of territory, authority, and rights that have sustained the Royal Bank of Canada's activities from 1864 to 2014, I argue that we should instead treat globalization as a novel epoch constituted by a centrifugal organizing dynamic that is moving the rights of capital and the authority over those rights to the transnational level. I claim that this process is transforming the nation-state from a capability to grow and develop national capitals into a capability for globalizing capitals as a result of new rights that restrict the ability of the nation-state to legislate against corporate interests. The dissertation concludes by reflecting on what this means for the future of Canadian liberal democracy and the struggle against global capitalism.
\end{abstract}




\section{Acknowledgements}

I am tempted to begin this section like Bruce Curtis and talk about the various experiences I've had while writing this dissertation rather than a long list of thanks. But I can't do that. There are too many wonderful people that contributed to this dissertation in one way or another simply by being themselves and I would be remiss not to mention them. To start, I'd like to thank Bruce himself, who shaped an unruly gang of doctoral students into scholars. Few of us would be where we are today without being challenged by his questions on epistemology and ontology—questions that I sometimes reflect on when I can't sleep at night; it doesn't help. I'd also like to thank Alexis Shotwell and Aaron Doyle for their efforts to teach me about teaching; it is rare to find scholars who care about teaching as much as they do and it is inspiring to see them work. A huge thanks must go out to Kara Brisson-Boivin, Mathieu Charbonneau, and the late Blake MacMillan. Their friendship, compassion, and understanding made all the difference; I treasure the time we spent together. I must also offer an immense thanks to my committee members Laura Macdonald and Janet Siltanen. Their comments on earlier drafts were incredibly helpful and they played a big role in shaping my ideas into a dissertation; furthermore, their kindness throughout the process was an inspiring model of how to be in the world. I also want to thank my examiners Randall Germain and Stephen McBride for their comments on my dissertation. A big thanks to Paula Whissell for all her help in navigating my various administrative hurdles. Perhaps the biggest thanks should go to my supervisor, Wallace Clement. At the most difficult moments of this dissertation, Wally provided exactly the right amount of support, patience, and kindness. Besides his uncan- 
ny ability to understand a research project, Wally provided a fantastic model of professionalism complete with warmth, humour, and encouragement. Canadian sociology will be at a significant loss when he retires. A big thanks must also go out to Saara Mortensen and all of my friends in Vancouver, Toronto, and wherever else they roam; without your friendship the darkest moments of this dissertation would have been far darker. Lastly, I would like to thank my parents for all their love and support over the years; if they gave out parenting awards they would surely be recipients in the category of fostering creativity, curiosity, and individuality. I love you both. And finally, as per the usual way of doing these things, while all these various people affected this dissertation in some form or another, I take all responsibility for any errors or misrepresentations. 


\section{Table of Contents}

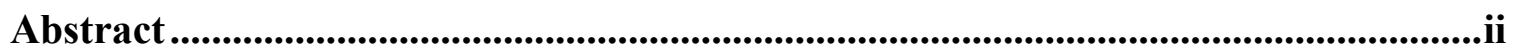

Acknowledgements..........................................................................................................ii

Table of Contents ..........................................................................................................................v

A Brief Timeline for the Royal Bank of Canada ..............................................................viii

List of Acronyms .........................................................................................................................

List of Tables and Figures............................................................................................................xiii

1. Introduction

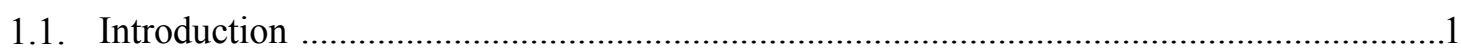

1.2. The Canadian Experience ……………………………………………………….

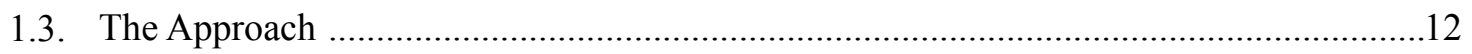

1.4. A Brief Note On Sources .......................................................................................18

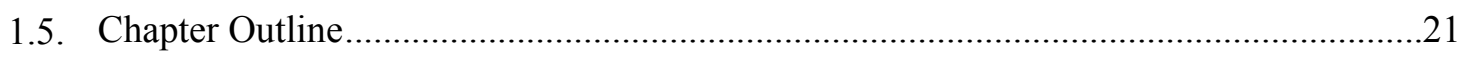

2. Some Canadian Reflections on Globalization and Financialization ..........................25

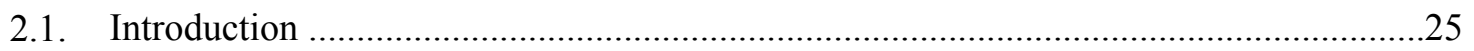

2.2. Theories of Imperialism and Dependency ……………………………………….....28

2.3. Debates in Canadian Political Economy ……………………………………………......44

2.4. New Developments in the Global Political Economy ……………………...................54

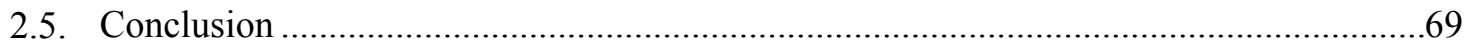

3. Property and Periodization: Thinking of Historical Property Regimes as Assemblages of Territory, Authority, Rights .................................................................................72

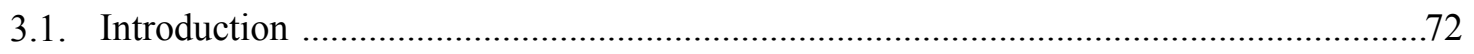

3.2. The Neglect of Banking in Critical Political Economy ……………………………........74

3.3. Historical Property Regimes as Assemblages of Territory, Authority, Rights....................84

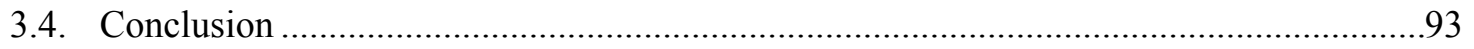




\section{Making National Capital: The Origin of the Royal Bank of Canada, 1864-1939.96}

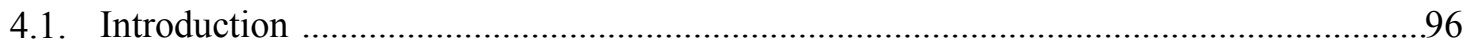

4.2. Pre-Confederation Banking and The Merchants Bank .................................................98

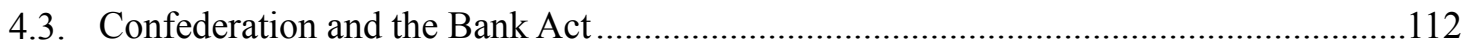

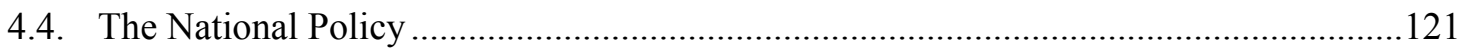

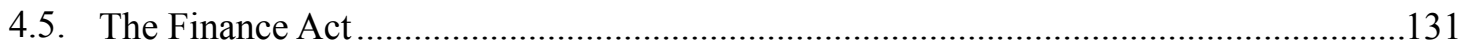

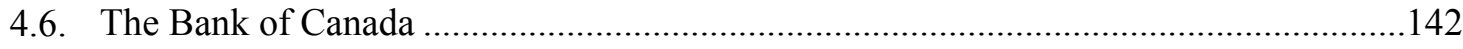

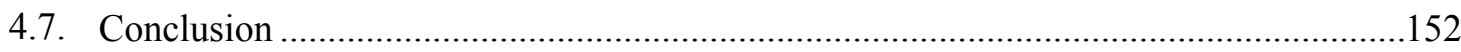

\section{The Expansion of National Capital: The Growth of the Royal Bank of Canada,}

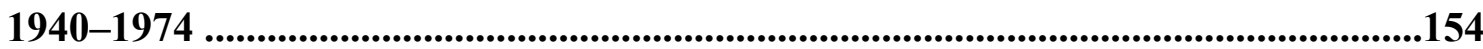

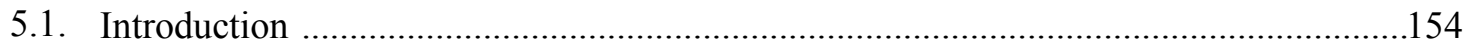

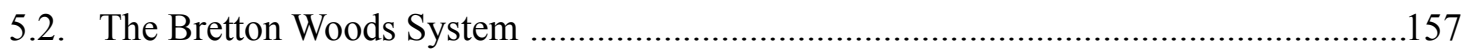

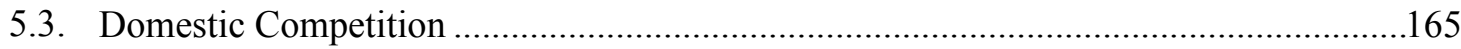

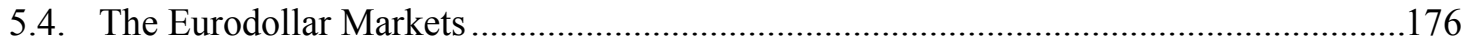

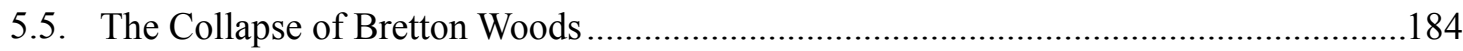

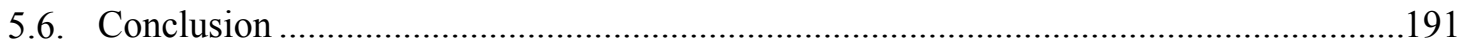

6. Making Global Capital: RBC in the Digital Age, 1975-2014 ..............................193

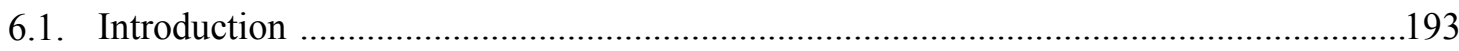

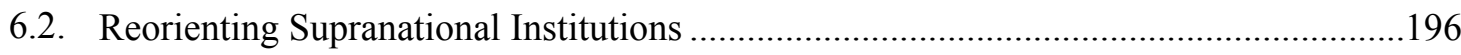

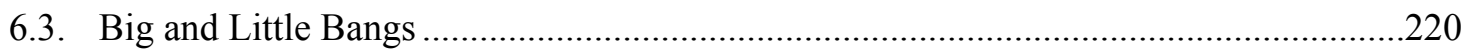

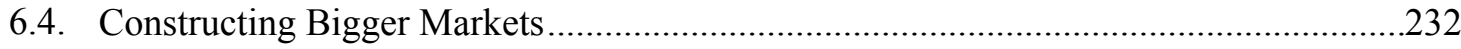

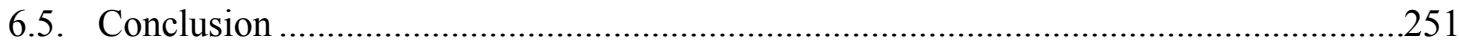

7. Emergent Trends and Implications ..............................................................................254

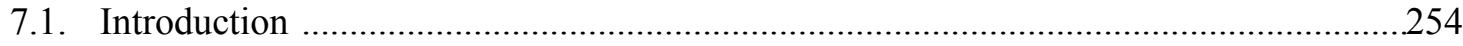

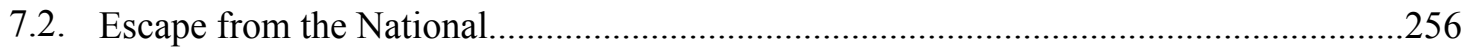

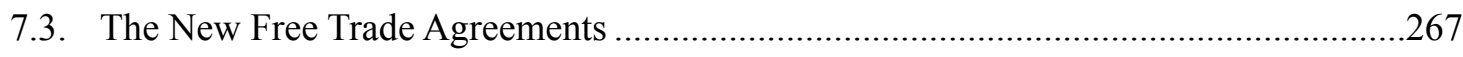

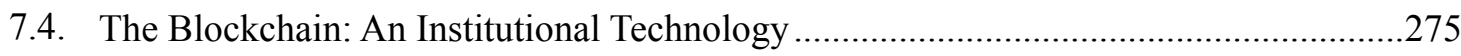




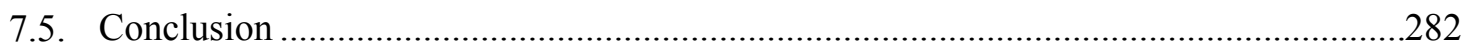

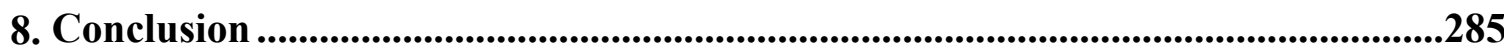

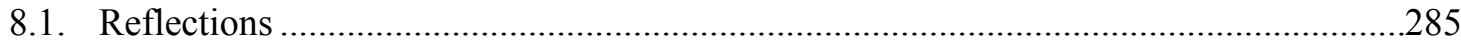

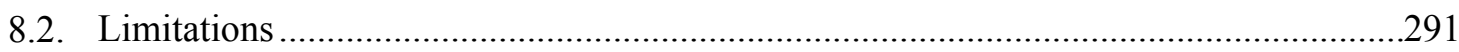

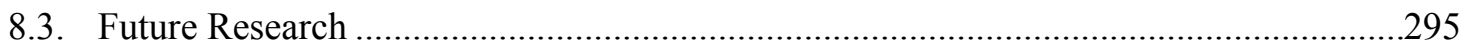

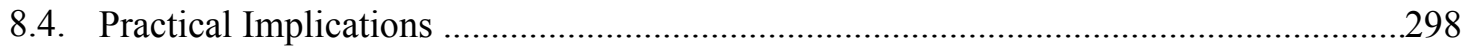

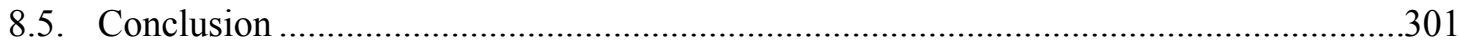

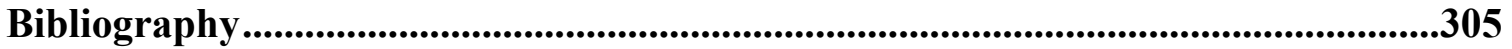




\section{A Brief Timeline for the Royal Bank of Canada}

- 1864: Merchants Bank founded in Halifax.

- 1867: Confederation

- 1869: Changed name to Merchants Bank of Halifax. Incorporated under federal charter.

- 1870: Branch opened in Pictou.

- 1871: Bank Act passed. Branches opened in Bridgewater, Truro, Weymouth, Antigonish, Lunenburg.

- 1872: Branch opened in Sydney.

- 1873: Branches opened in Maitland, Charlottetown.

- 1874: Branch opened in Summerside.

- 1877: Branch opened in Souris.

- 1879: National Policy.

- 1881: Branch opened in Port Hawkesbury.

- 1882: Opened first international branch in Bermuda. Also opened branches in Baddeck, Guysborough, Sackville, Richibucto, Bathurst, Kingston, Dorchester.

- 1883: Branch opened in Newcastle.

- 1885: Branch opened in Paspebiac.

- 1886: Branch opened in Moncton, St. Pierre and Miquelon.

- 1887: Branches opened in Fredericton, Woodstock, Montreal.

- 1889: Bermuda branch sold.

- 1891: Canadian Parliament granted Canadian Bankers Association the right to block charters for new banks.

- 1895: Branch opened in Newfoundland.

- 1899: Branches opened in Cuba and New York.

- 1901: Changed name to Royal Bank of Canada.

- 1907: Branch opened in Puerto Rico. Moved head office from Halifax to Montreal.

- 1910: Branches opened in London, Winnipeg, and Trinidad. Acquired Union Bank of Halifax.

- 1911: Branches opened in Jamaica and Barbados.

- 1912: Branches opened in Dominican Republic and Belize. Absorbed the Traders Bank of Canada to improve position in Ontario.

- 1913: Branches opened in Grenada and Guyana.

- 1914: Finance Act

- 1915: Branches opened in Antigua, Dominica, St. Kitts, Costa Rica.

- 1916: Branch opened in Venezuela.

- 1917: Branches opened Nevis, Montserrat, and Tobago. Absorbed Quebec Bank.

- 1918: Branch opened in Spain. Absorbed Northern Crown Bank to give it a better position in Manitoba and Saskatchewan.

- 1919: Branches opened in Paris, Russia, Haiti, Guadeloupe, Martinique, Argentina, Brazil, Uruguay.

- 1920: Branches opened in St. Lucia, Columbia. 
- 1925: Purchased Bank of Central and South America. Opened branch in Peru.

- 1929: Branch opened in Panama. Black Tuesday.

- 1934: Bank of Canada created. Bank of Montreal ceases to be the government's bank.

- 1938: Bank of Canada nationalized.

- 1940: Royal has 65 operating units in 15 countries outside Canada.

- 1944: Bretton Woods agreement signed.

- 1949: Bank of Canada became sole issuer of currency.

- 1954: Entered into correspondent relationship with Bank of China.

- 1957: Eurodollar markets created.

- 1958: Branch opened in Hong Kong.

- 1959: Branch opened in St. Vincent.

- 1960: Royal left Cuba.

- 1961: Royal installed first computer.

- 1964: Branch opened in Cayman Islands.

- 1966: Branch opened in Lebanon.

- 1967: Revision to Bank Act disallowed any single investor from owning more than $10 \%$.

- 1969: Branch opened in West Germany.

- 1970: Orion Bank Ltd. formed in London. Branches opened in Japan and Australia. Now has 125 operating units in 30 countries outside Canada.

- 1972: Royal Bank of Canada in Trinidad sold 51\% of its equity to local nationals on a five-year payment scheme, becoming Royal Bank of Trinidad and Tobago.

- 1973: Forced to incorporate operations in Jamaica, becoming Royal Bank (Jamaica). Bretton Woods system collapsed.

- 1974: Branches opened in independent Africa, the Philippines, and Dubai. Basel Committee on Banking Supervision formed (initially the Committee of Banking Regulations and Supervisory Practices).

- 1975: Branch opened in Singapore.

- 1978: Branch opened in South Korea.

- 1979: Branches opened in Mexico and Egypt. Gains first retail banking operation in England.

- 1980: Has more than 200 operating units in 45 countries outside Canada. Acquires Banco de San Juan in Puerto Rico.

- 1981: Branches opened in Thailand and China.

- 1983: Branch opened in Taiwan.

- 1984: Left Guyana.

- 1985: Started to withdraw from most of the Caribbean.

- 1986: Branch opened in India. England's Big Bang.

- 1987: Canada's Little Bang.

- 1989: Canada-United States Free Trade Agreement went into effect.

- 1990: Has more than 125 operating units in 32 countries outside Canada.

- 1993: Sold banks in Puerto Rico and Brazil. Merged operations with Royal Trust. 
- 1994: Royal Trust opened office in Bermuda. North American Free Trade Agreement went into effect.

- 1995: Branch opened in Chile.

- 1996: Integrated trading units. Now operates out of 20 locations including London, New York, Montreal, and Toronto.

- 1998: RBC Dominion Securities opened in a number of Caribbean locations. Royal Bank of Canada acquired First Network Bank in Atlanta; the first pure internet bank. Attempted to merge with Bank of Montreal; rejected by Minister of Finance.

- 1999: Major restructuring; closed offices in Asia and Latin America. Acquired firms in Channel Islands.

- 2000: Has more than 300 offices in over 30 countries outside Canada. Reoriented strategy around North America. Became one of the largest trust companies in Channel Islands. Acquired Dain Rauscher Wessels, a U.S. brokerage and investment banking firm.

- 2001: Acquired Centura Bank in North Carolina as well as firms in Australia.

- 2002: Branch opened in Brunei.

- 2004: Global private banking offices opened in Spain and Turkey.

- 2005: Became member of Australian Stock Exchange. Acquired a number of British financial firms.

- 2006: Created institutional investment joint venture with Dexia.

- 2008: Acquired Royal Bank of Trinidad and Tobago; this creates one of the largest banking networks in the Caribbean with a presence in 18 countries and territories. Opened wealth management offices in India and Chile.

- 2009: Acquired Mourant Private Wealth, with operations in Jersey, Dubai, and Cayman Islands.

- 2010: Acquired London-based Bluebay Asset Management.

- 2012: Acquired Latin American, Caribbean, and African private banking business Coutts (wealth division of Royal Bank of Scotland). Completed acquisition of Dexia's $50 \%$ stake in their joint venture.

- 2013: Completed acquisition of Canadian subsidiary of Ally Bank.

- 2014: Entered into merger agreement to acquire City National Corporation. 


\section{List of Acronyms}

BATS: Better Alternative Trading System

BCBS: Basel Committee on Banking Supervision

BCC: Business Council of Canada

BCE: Bell Canada Enterprises

BCNI: Business Council on National Issues

BIS: Bank of International Settlements

BIT: Bilateral Investment Treaties

BMO: Bank of Montreal

BOC: Bank of Canada

CDIA: Canadian Direct Investment Abroad

CETA: Comprehensive Economic and Trade Agreement

CIBC: Canadian Imperial Bank of Commerce

CMHC: Canada Mortgage and Housing Corporation

CPR: Canadian Pacific Railway

CSCE: Conference on Security and Cooperation in Europe

CUFTA: Canada-United States Free Trade Agreement

DAO: Decentralized Autonomous Organization

ECLAC: Economic Commission for Latin America and the Caribbean

EU: European Union

FDI: Foreign Direct Investment

FECB: Financial Exchange Control Board

FSB: Financial Stability Board

G7: Group of Seven

G10: Group of Ten

G20: Group of Twenty

GATT: General Agreement on Trade and Tariffs

GATS: General Agreement on Trade in Services

HFT: High-Frequency Trading

IBC: International Business Company

ICSID: International Centre for Settlement of Investment Disputes

IEX: Investors Exchange

IIA: International Investment Agreement

IIROC: Investment Industry Regulatory Organization of Canada

IMF: International Monetary Fund

ING: Internationale Nederlanden Group

ISDS: Investor-State Dispute Settlement

KIO: Kuwait Investment Office

KWS: Keynesian Welfare State

LDC: Less Developed Country

M\&A: Mergers and Acquisitions

MBNA: Maryland Bank of North America 
MNC: Multinational Corporation

NAFTA: North American Free Trade Agreement

NCPE: New Canadian Political Economy

NDP: New Democratic Party

OECD: Organization for Economic Co-operation and Development

OMERS: Ontario Municipal Employees Retirement System

OTF: Ontario Teachers' Federation

P2P: Peer-to-Peer

PACER: Pacific Agreement on Closer Economic Relations

RBC: Royal Bank of Canada

RCEP: Regional Comprehensive Economic Partnership

REG NMS: Regulation National Market System

RHOSP: Registered Home Ownership Savings Plan

RRSP: Registered Retirement Savings Plan

SEC: Securities and Exchange Commission

TAR: Territory, Authority, Rights

TiSA: Trade in Services Agreement

TCC: Transnational Capitalist Class

TD: Toronto-Dominion Bank

THOR: Tactical Hybrid Order Router

TNC: Transnational Corporation

TNS: Transnational State Apparatus

TPP: Trans-Pacific Partnership

TSX: Toronto Stock Exchange

TFW: Temporary Foreign Worker

TFWP: Temporary Foreign Worker Program

UNCTAD: United Nations Conference on Trade and Development

WB: World Bank

WTO: World Trade Organization 


\section{List of Tables and Figures}

Figure 1: Known Investor-State Dispute Settlement Cases 68

Table 1: Number of Branches, $1909 \quad 130$

Table 2: The Royal's Growing Branch Network in 1918

Table 3: Total Assets of Canada’s Chartered Banks, 1930

Table 4: Bank Absorptions in Canada, 1867-1928 151

Table 5: Branches of Canadian Chartered Banks in Canada, $1950 \quad 169$

Table 6: Branches of Canadian Chartered Banks Outside Canada, $1967 \quad$ 183-184

Table 7: Global Ranking of Canadian Banks, 1970-2000 191

Figure 2: Bank of Canada Holdings of Government Debt vs Total Debt Outstanding at

$\begin{array}{ll}\text { Government of Canada } & 200\end{array}$

Figure 3: Canada's Debt in Inflation-Adjusted Dollars 1961-2010 202

Table 8: Royal Bank of Canada, Annual Statistics, 1974-1985 220

Table 9: North America’s 10 Largest Banks in 1991

Table 10: Canada’s Biggest Companies By 2007 Revenue 251

Figure 4: Existing International Investment Agreements and New Bilateral Relationships

Created, for Six Megaregional Agreements $\quad 270$

Figure 5: Trends in International Investment Agreements Signed, 1983-2013 275

Table 11: World's Largest 25 Banks, 2015

Figure 6: Part of Me is Going to Miss Liberal Democracy 304 


\section{Introduction}

The ideas which are expressed here ... are extremely simple and should be obvious. The difficulty lies, not in the new ideas, but in escaping from the old ones, which ramify, for those brought up as most of us have been, into every corner of our minds.

—John Maynard Keynes, 1936.

When we leave normal times and deal with periods of rapid social change (whether revolutionary or retrogressive), we are bound to expect even greater dislocations between the changing socioeconomic base and the politicalideological superstructure. It is virtually a defining characteristic of such periods that all social relations become upset, volatile, fluid. Formulas that worked 'as a rule' in stable times now become more variable approximations; it is necessary to go behind the formulas to keep close watch on the concrete patterns of change.

—Hal Draper, Social Activist and Author, 1977.

\subsection{Introduction}

In this dissertation I examine the changing assemblages of territory, authority, and rights (TAR) that have sustained the Royal Bank of Canada's activities from 1864 to 2014. The purpose of doing so is to examine the different ways in which these elements have been arranged over time so as to better understand the implications of our current epoch, 'globalization.' To put it simply, this dissertation is an attempt to understand where we have been, where we are, and where we are going. The need to understand where we are and where we are going stems from a personal desire to know how to best struggle against global capitalism. While many continue to see the nation-state as the primary site of social and political struggle, I argue in this dissertation that this 'location' or 'level' is no longer an adequate site of resistance. I make this argument on the basis that our current period is characterized by a centrifugal organizing dynamic that is moving the rights 
of capital and the authority over those rights to the transnational level. I claim that this movement is an epochal-level reorganization of the global political economy representing the construction of a global system of rights for capital that lies beyond the grasp of national politics. By restricting the ability of the nation-state to be used as a vehicle to legislate against the interests of capital, this movement reduces not only the efficacy and meaning of liberal democracy, but the extent to which the nation-state can be used for successful social reform. To illustrate this reality, it might be best to begin with some recent history.

In the aftermath of the 2008 financial crisis, almost all commentators agreed that something had to be done. The solutions varied, of course. As always, the Marxists argued that reform was not enough; that the real solution was no less than the total nationalization of the banks (Ackerman, 2012; Lapavitsas, 2013; Teles, 2016). In their view, this would turn "the financial institutions that are the life-blood of global capitalism into public utilities that would facilitate, within each state, the democratization of decisions that govern investment and employment" (Panitch \& Gindin, 2012, p. 340). In stark contrast, the Neo-Keynesians argued that the problem was not so much the power of large financial firms, but the fact that they all received huge bailouts that subsequently committed national governments to a number of various 'austerity' measures to reduce state debt. "What the world needs now," wrote American economist Paul Krugman (2012), "is for governments to step up their spending to get us out of this depression” (p. 39). Alternatively, in his now famous, Capital in the Twenty-First Century, French economist Thomas Piketty (2014) claimed that the real solution to rising inequality was a progressive annual 
tax on capital; in his view, this "would make it possible to avoid an endless inegalitarian spiral while preserving competition and incentives for new instances of primitive accumulation" (p. 399).

While these solutions were interesting in their own right, they were especially fascinating because, regardless of the commentator, they were all declared fundamentally unworkable. The Marxists noted, for instance, that any nationalization of the banks would have to rely on the "revival of a progressive economic nationalism" that has all but been "ruled out by the absence of anything like a national bourgeoisie for popular classes to ally with" (Panitch \& Gindin, 2012, p. 340). Similarly, in the same breath that he suggested a progressive tax on capital, Piketty (2014) warned his readers that such a tax would be difficult to achieve since it would entail "a high level of international cooperation and regional political integration" that is not currently "within the reach of the nation-states in which earlier social compromises were hammered out" (p. 399). Joseph Stiglitz (2008), the American economist who famously commented in late 2008, "we are all Keyensians now" (para. 1) put the matter plainly: "this global crisis requires a global response, but, unfortunately, responsibility for responding remains at the national level" (Stiglitz, 2009, para. 2).

That so many scholars could, on the one hand, point to the problem, while, on the other, noting why their solution wouldn't work, seemed to suggest that there were larger, more structural issues at play; that the global political economy had changed to such a degree that, for one reason or another, those past solutions (which might have worked, if only the conditions were ripe!) were no longer tenable. Part of the problem thus has to do 
with globalization; or, more accurately, the depth and extent of change that globalization represents. As it stands, however, there is very little consensus as to the meaning of the term, with it being defined in a variety of ways: as an "increasing number of social processes that are indifferent to national boundaries (Beck, 2000, p. 80); the "capacity to work as a unit on a planetary scale in real time or chosen time" (Castells, 2000, p. 10); the "intensification of worldwide social relations which link distant localities in such a way that local happenings are shaped by events occurring many miles away and vice versa" (Giddens, 1990, p. 64); the "widening, deepening and speeding up of worldwide interconnectedness in all aspects of contemporary social life" (Held et al., 1999, p. 2); "the compression of the world as a whole" (Robertson, 1995, p. 40); "circumstances where territorial space is substantially transcended" (Scholte, 1999, p. 12); and "the rapid developing and ever-densening network of interconnections and interdependencies that characterize modern life" (Tomlinson, 1999, p. 2). ${ }^{1}$ Suffice it to say that globalization is an essentially contested concept (Gray, 1977).

Insofar that scholars agree that globalization represents some measure of change to the global political economy by virtue of the increased interconnectivity of economic activities, the depth and extent of this change is hotly debated. One influential school of thought in studies of the world economy, for instance, argues that economic globalization is overstated or even illusory, claiming that our current period is merely a quantitative intensification of historical tendencies; that since earlier periods of capitalism were also characterized by relatively open systems of trade and commerce that globalization is sim-

1 This list of definitions was produced by Fuchs (2010). For more, see Coleman and Sajed (2013). 
ply more of the same (e.g., Boyer \& Drache, 1996; Glyn \& Sutcliffe, 1992; Gordon, 1988; Helleiner, 1997; Hirst \& Thompson, 1996/2015; Kapstein, 1994; Weiss, 1997; Wood, 1999). The Marxist geographer David Harvey (2000) argues, for example, that "something akin to 'globalization' has a long presence within the history of capitalism" (p. 54). Similarly, the economist William Tabb (2009) writes that "the most significant features of what is called globalization have always been part of capitalist development, even if the forms are different in different periods (including our own)" (p. 1). Analogous statements can be found when scholars make references to “today's globalization" (Panitch, 1994, p. 63) or "the recent bout of globalization" (Harvey, 2009, p. 98).

Whether borrowed from Marx's (1894/1991a) claim that "the world market itself forms the basis for this [capitalist] mode of production" (p. 451) or Immanuel Wallerstein's (2010) conception of a capitalist world-system, this school of thought believes that globalization is not so much a stage, period, or phase of capitalism, but rather, a periodic expression of capital's inherent need to expand. "They may call it globalization," Ellen Meiksins Wood (1998) writes, "but it is really just capitalism" (p. 8). In viewing the phenomenon as the resurgence of a pre-existing tendency of capitalism itself, these scholars do not see globalization as challenging the system of territorial nation-states that makes up the global political economy; as they frequently point out, nation-states are not only the "authors and enforcers" (Panitch \& Gindin, 2005, p. 101) of globalization, but "global capitalism is more than ever a global system of national states" (Wood, 2002a, p. 25). As such, many who take the view that globalization is not a new phenomenon tend to treat our current period as a return to the conditions of the earlier stage of imperialism and fi- 
nancialization that characterized the period spanning the late 19th and early 20 centuries (e.g., Bromley, 2003; Callinicos, 2009; Foster, 2003; Harvey, 2003a; Norfield, 2016; Panitch \& Gindin, 2012; Smith, 2016a; Wood, 2003).

It is certainly not surprising that so many scholars see our current period as similar to the first wave of financial ascendancy that characterized the late 19th and early 20th centuries. As Lapavitsas (2013) notes, multinational corporations dominate global economic activity; global banks play a leading role in international finance; capital exports have grown substantially; a certain type of political and military imperialism has reasserted itself, led by the U.S. but facing powerful challenges from other powers (p. 44).

There are important differences, however. Our present period is not characterized by "exclusive trading zones associated with territorial empires, and banks are not dominant over non-financial enterprises" (p. 56) despite the ubiquity of financialization today—a term that, like globalization, has no clear definition.

These differences have led a growing number of scholars to argue that globalization is not merely the resurgence of a pre-existing tendency, but an entirely new epoch within the history of world capitalism (e.g., Demirović, 2011; Hardt \& Negri, 2000; Harris, 2005; Liodakis, 2010; Robinson, 2004, 2014; Sklair, 2001; Sklair \& Robbins, 2002). This school of thought, often referred to as the global capitalism school, claims that globalization is leading to the development of new transnational class and state forms that are absorbing elements of power, control, and authority that have long been institutionalized at the national level. They argue that these changes necessitate an entirely new way of 
thinking about the expansion of capital that breaks with the nation-state centrism of these existing theories of globalization. Where, in the previous national epoch, capitalists might have turned to their own nation-states to pursue their class interests, this school of thought maintains that in our current epoch—globalization- the transnational fraction of the capitalist class is attempting "to convert the entire world into a single unified field for global accumulation" (Robinson, 2014, p. 7). They argue that as a result of this process, the class relations of global capitalism are now "so deeply internalized within every nation-state that the classical image of imperialism as a relation of external domination is outdated" (Robinson, 2007, p. 23). The real phenomenon that requires explaining according to them is thus "the contradiction between the descending form of capitalism organized around the nation-state system and an arising form of accumulation organized in the transnational world order" (Harris, 2005, p. 329).

At the root of the disagreement between these two sides is whether globalization has displaced the nationality of capital and nation-states as the key units of the global political economy. For the Marxists more specifically, the key indicator that should tell us the answer is typically the status of capital itself: if capital is proven to be national, then globalization should be understood as a new form of imperialism; if capital is proven to be transnational, then we need to rethink the relationship between capital and the nationstate system; or, at least, that's how the argument has been framed so far. The overall effect has been a mass of work going back and forth, attempting to point out that production, class, accumulation, among other stand-ins for capital, are more or less national, 
more or less global. So far, neither side has been able to overcome the basic antagonism between continuity or change that sits at the heart of the globalization debate.

\subsection{The Canadian Experience}

These debates about the configuration of the global political economy today necessarily have implications for the countries that compose it. In my home country of Canada, the changing nature of the global political economy was made clear in the lead up to the 2015 federal election. After the New Democratic Party (NDP) - Canada's formerly socialist, now kind-of social democratic party — was publicly criticized for telling voters that they would balance the budget, run no deficits, and were no danger to Canada's credit rating, Janice Mackinnon, the former NDP finance minister for Saskatchewan, admitted that it was not so much that the NDP did not want to tax the rich, but that this act was no longer possible:

The idea of taxing the rich is a critical 1960s NDP idea. What we had to come to grips with is, in a late 20th, early 21 st century economy, you can't do it ... It's a global economy, it's a competitive economy. We'd all love to tax the rich on the left, but on the ground, it no longer works (as cited in Hall, 2015, para. 17-19).

Indeed, as sociologist Alain Deneault (2011) notes, capital today does not simply move around the world with relative ease, but it does so through an offshore network of tax havens that work to hide vast sums of money from national governments. One certainly does not need an advanced degree in economics to understand why Canada's largest bank, the Royal Bank of Canada, registered 378 shell companies with Mossack Fonseca, 
a Panama-based law firm that was recently discovered to be hiding trillions from national governments around the world (Kiladze \& Marotte, 2016).

That capital can so easily escape the reach of the nation-state, however, requires some level of explanation. As a significant part of globalization, the escape of capital from national-level regulations effectively undermines nation-state sovereignty by not only restricting the available policy options available to national governments, but by forcing them to borrow vast sums (typically from financial institutions) to make up for lost tax revenue. Furthermore, the investor-state dispute mechanisms found in many biand multilateral trade agreements grant corporations the right to sue governments for policies that work to restrict their ability to accumulate capital (Clarkson \& Wood, 2010; McBride, 2011). Taken together, these changes not only pervert the competitive party system at the heart of liberal democracy, making it "into a sham of competition between political parties with more or less the same agenda" (Teeple, 2007, p. 141) but seem to raise larger questions about the constitution and novelty of our age itself.

Despite these changes, many Canadian scholars continue to view Canada within a conceptual framework of competing national capitals and states. Over the last decade, there has been a revival of a longstanding debate as to whether Canada should be understood as a rich dependency, subordinate to its imperial masters, or as an imperialist power whose development has more or less tracked that of other advanced capitalist countries (e.g., Albo \& Klassen, 2013; Carroll, 2012; Burgess, 2000, 2002; Deneault \& Sacher, 2012; Gordon, 2010; Hurtig, 2003; Ikeda, 2004; Kellogg, 2005, 2009, 2015; Klassen, 2008, 2009, 2014; McQuaig, 2007; Seccareccia, 2007; Stanford, 2008, 2014; Watkins, 
2007). While I review this debate in greater detail in chapter two, for now we need simply note that the two sides rest their claims on the status of Canada's dominant capital. The dependency interpretation views Canada's dependency as resulting from the country's longstanding domination by foreign capital, mainly British and American (e.g., Drache, 1977; Levitt, 1970; Lumsden, 1970; Naylor, 1975/1997; Teeple, 1972). They argue that the country's underdevelopment (as compared to the United States) is the result of a historically dominant mercantile-financial ruling class whose interest in short-term gains has ended up orienting the economy toward resource extraction and branch-plant manufacturing, and thus, low productivity and technological imports. Canada is therefore seen as a vanishing country (Hurtig, 2003) that is sleepwalking into the U.S. empire as a result of a ruling class who press "for policies — both domestic and foreign - that please the U.S. elite" (McQuaig, 2007, p. 59). The solution, these scholars claim, is to be found in policies pushing for greater economic self-reliance, which would allow Canada to realize its own destiny.

In contrast, the imperialist interpretation takes issue with the idea that Canada continues to be dominated by foreign capital. Continuing the argument begun by earlier critics of the dependency approach (e.g., Carroll, 1986; Kaufman, 1985; Moore \& Wells, 1975; McNally, 1981; Niosi, 1985; Resnick, 1982; Veltmeyer, 1987) scholars arguing the contemporary version of the imperialist interpretation argue that a substantial majority of assets and revenues within Canada are owned and controlled by Canadian capitalists and that this represents "a long-term tendency, well entrenched now for more than 30 years" (Kellogg, 2005, p. 36). Their central piece of evidence is the fact that Canada now 
exports more capital than it imports, thus giving it "the classic profile of an imperialist power" (p. 48). For Jerome Klassen (2014) and William Carroll (2012) this makes Canada part of a collective imperialism of advanced capitalist states that manage the global economy and maintain the hierarchy between the core and the periphery. In other words, as Klassen (2014) notes, they believe that "the concept of empire, or imperialism, best explains Canada's role in the world economy and the nation-state system today" (p. 30).

The main problem, as I see it, is that capital is not a 'thing,' but rather, a social relationship. While it is certainly fine to refer to large corporations as 'capitals' (as I do in this dissertation) it is important to recall that what we are referring to is an agglomeration of capital centralized within a particular form of property: the corporation. Pointing to the national-ness or global-ness of a corporation tells us little about why or how the shape and structure of the global political economy is changing; nor, why there are so few strategies to deal with the immense power of capital today. While it may be true that Canada's capitalist class has retaken the majority of assets in the domestic market, this does not necessarily mean that Canada is, by definition, now an imperialist power. As many scholars point out, this shift can just as easily be explained as the result of changing patterns of American investment (e.g., Baragar \& Seccareccia, 2008; Soederberg, 2000; Sweeny, 1997). To put it simply, there may be something else going on. My intention is therefore not to simply continue the debate over Canada's 'place' or 'location' within the global political economy, but to instead ask whether Canadian capitalism can still be captured in the basic terms of this debate? In other words: can many of the novel changes 
associated with globalization be captured under the conceptual framework of imperialism and dependency? And, if not, how might we attempt to understand what is going on?

\subsection{The Approach}

To answer these questions, my dissertation provides a comparative-historical case study of the Royal Bank of Canada from 1864 to 2014. The attempt, here, is to limit the theoretical scope of globalization and its concrete application in the sphere of empirical research through a close case study that can explore how the terrain of action on which capitalist activity takes place has changed over time. To do this, I combine Karl Marx's many insights into property with the conceptual framework created by the sociologist Saskia Sassen (2006) in Territory, Authority, Rights. The main idea is that all human communities (or social formations or units) are defined by their respective property relations; it is important to note, here, that I am not referring to property as 'things,' but rather, as the historically-specific social relations that govern the relative allocation of rights to 'things.' Viewed as such, property is not merely ownership, but that which links the economic, political, and legal institutions of any given society, giving it its specific 'shape' and dynamic. The constitution of any property regime is not the outcome of some efficient process, but rather, a continuous and contestable social and political struggle in which organized groups try to affect the outcome (Fligstein, 2002, p. 33). In this sense, state building is the process by which certain groups are able to get political institutions to make rules that benefit their interests. 
Since any property regime implies a territory over which rights apply, as well as an authority to enforce them, I use Sassen's (2006) framework to conceptualize property regimes as assemblages of territory, authority, and rights (TAR). In doing so, I am able to avoid comparing the national and the global as complex wholes and instead treat them as different property regimes whose capabilities (defined as institutionalizations of TAR) eventually reach tipping points that lead them to 'jump tracks' and support an altogether new organizing logic. Tipping points, here, refer to events, defined "by their significance as markers of transition" (Abrams, 1982, p. 195). As Sewell (1996) defines them, they are "sequences of occurrences that result in transformations of structures" (p. 843). An organizing logic is defined as the prevailing organizational formation in which capabilities become institutionalized. In this sense, we can identify three sorts of property regimes: the centrifugal scalings of the medieval, which consists of several encompassing normative orders; the centripetal scaling of the modern nation-state, constituted by one master normativity; and the centrifugal scalings of the global that, according to Sassen (2006), "disaggregate that master normativity into multiple partial normative orders, thereby leaving open the question as to its sustainability" (p. 10).

The focus, here, is macroscopic, rooted in the idea that "there are foundational differences between the world scale of several earlier phases of the world economy and today's global economy" (p. 14). The purpose of using such an approach is to better identify those things that might be labelled as national, such as the nation-state, but now support a global organizing dynamic. While the organizing logic of the national and global epochs of capitalism are each constituted by states and world political economies, they 
are each aligned differently and with different outcomes. The emphasis, here, is thus on getting away from the view, so common in the debates over globalization, "that the sum of a given set of parts inevitably produces the same key assemblage" (p. 15). As Sassen (2006) notes, this can only be done by demonstrating how "key capabilities developed in an earlier phase can become foundational to a subsequent phase but only as part of a new organizational logic that in fact also foundationally repositions those capabilities" (p. 15).

For our purposes, this means focusing on the nation-state as a capability for the development of capital. Where other approaches point to the nation-state as evidence that globalization is nothing new, my argument in this dissertation is that specific elements of TAR are shifting in ways that are significantly transforming the role and 'shape' of the nation-state in different ways than in decades past. In particular, I highlight the movement of the rights of capital and the authority over those rights to the transnational level over the last 40 years as an epochal-level shift that is transforming the nation-state from a capability to develop and grow local capitals into a capability for globalizing capitals.

To explore these changes, I trace the transformation of the Royal Bank of Canada over time to investigate how these different organizing logics have effected the bank's abilities and capacities; in other words, what it has been allowed to do at particular times and the implications of the right to do so. There are two reasons in particular why I chose to examine the history of a Canadian bank. The first is that banking is an ancient economic activity; as such, an analysis of its history can provide us with a means of distinguishing between the earlier national economy centred on international trade and capital flows governed by nation-states and today's global economy, which, as Sassen (2014a) notes, is 
"centred on powerful firms using national governments to make private global space for their operations" (p. 2). While both periods involve various forms of outward expansion and primitive accumulation (that is, the often brutal transformation of non-commodities into commodities) the earlier period involved a capitalist core dominating a non-capitalist periphery (see, e.g., Wood, 2003). Today, however, "it is the very advanced sectors of the economy that are appropriating the resources of what was till recently the 'advanced' capitalist economy" (Sassen, 2014a, p. 2). As Sassen (2014a) notes, no sector illustrates this quite "as well and as dramatically as high finance, the most complex and also most predatory advanced sector" (p. 2). Indeed, what used to be the study of boring bankers who followed the 3-6-3 rule- "take in deposits at 3\%, lend the money at $6 \%$, and be on the golf course by 3PM" (Carruthers \& Kim, 2011, p. 240) - has since become the study of an incredibly dynamic, complex, interdependent, and ultimately unstable, sector of the global economy by virtue of the breakdown of the traditional barriers dividing banks, trust companies, investment dealers, and insurance companies in the $1980 \mathrm{~s}$; in other words, the transformation of banking into finance. As a result, the global financial system is now "the cutting edge of global class relations insofar as property/ownership relations are structured on a global scale through the circuits of financial capital" (Robinson, 2014, p. 140). Despite a significant literature on the sociology of banking and finance, however, there is almost no historical research that investigates how the property relations that govern banking have changed over time, nor the implications (see, e.g., Carruthers \& Kim, 2011; Keister, 2002; Samman et al., 2015). In other words, much of this research tends to take for granted the actual institutional configurations and social relationships 
that have made capitalist banking possible over time. By focusing on the transformation of a small regional bank-cum-transnational financial institution I argue that we can better understand the constitution of our age. Indeed, the economist Richard Grossman (2010) suggests that: "identifying the forces that historically have been responsible for banking evolution may provide some insight into understanding those at work today" (p. 2).

The second reason for examining the evolution of banking is that all theories of Canadian dependency and imperialism base at least some part of their claim on the strength of Canada's small, but incredibly powerful, banking sector. Where dependency theorists see the strength of the chartered banks as an indicator of the country's over-reliance on commerce relative to productive manufacturing activities, imperialist theorists see it as a sign of Canada's advanced industrial status. Early banking functions were provided by Montreal merchants as credit channels from Britain and, "as early as 1792, private banks led by merchants in Montreal began to petition for chartered status" (Clement, 1975, p. 53). Resulting from the specific character of early British merchant capitalism, these early banks specialized in the staples trade (e.g., fish, fur, wheat) and did not often provide loans to industrial ventures. As a means of enriching the 'gentlemanly capitalists' who owned them (a concept explained in chapter four) the early banks were all aligned with the dominant power interests in their respective provinces:

The Bank of Montreal was controlled by the Chateau Clique and was the official government bank; the Bank of Commerce and Bank of Upper Canada were the Family Compact's response to the Bank of Montreal; the Halifax Banking Company (later Bank of Nova Scotia) was the Maritime's answer (p. 53). 
Unlike the American banking system, which developed as a number of smaller unit banks as a result of the earlier push toward free banking (see, e.g., Dwyer, 1996), Canada's banks have always been large and oriented toward the financing of international trade. As political economist R.T. Naylor (1975/1997) notes, this is because:

The Canadian banking system, like virtually all of the country's economic institutions, was a truncated import from a more advanced economy, specifically from England. What is important is not the nationality of the bankers per se, (who were largely Scots) nor the legal niceties attached to early charters (which were largely American-derived), but the actual functioning of the banks. And in this respect the Canadian banking system was a colonial variant of London joint stock commercial banking (p. 66).

As a colonial variant of English commercial banking, Canada's early banks were thus some of the country's first transnational enterprises, providing retail and commercial linkages between both core and peripheral states. In the 19th century, for instance, branches in New York and London were created to provide profitable links to the Canadian resource market, while branches in the West Indies and Latin America provided commercial banking services to facilitate trade with the United States (Marchildon \& McDowall, 1992). As Neil Quigley (1989) notes, Canada's banks "were pioneers in the combination of domestic retail operations with international branch banking and the finance of trade between foreign countries" (p. 837). Given that many of these practices continue today on a much larger scale, it follows that an examination of the evolution of Canadian banking should provide us with significant insights into what is different about 
our current epoch and why capital seems so impossibly powerful today. Indeed, as John Chant (1979) pointed out much earlier: "any examination of "major concentrations of corporate power' in Canada would be incomplete without a close scrutiny of the role of the chartered banks" (p. 191). As the largest bank in Canada since 1925, there is thus no better bank to examine than the Royal Bank of Canada.

\subsection{A Brief Note On Sources}

It is important to provide a brief note on the sources used in this dissertation. The astute reader will observe that I rely heavily on Duncan McDowall's (1993) official history of the Royal Bank of Canada, Quick to the Frontier. I do so because there is so little publicly available information on the Royal Bank of Canada. Scholars as diverse as Alain Deneault (2015), P.J. Hudson (2010) and James Darroch (1994) have all noted this difficulty in their own attempts to shine some light on the activities of the Royal and this dissertation is no different. The Royal's archives are private and my own attempt to get access to them was unsuccessful. In personal correspondence with Hudson, I was pointed back toward McDowall's book. While I have done my best to accompany my use of that text with corporate documents, newspaper articles, and the findings of official reports and commissions, there is no doubt a wealth of material that remains hidden to public eyes.

Despite this general lack of information, I still feel that it is important to highlight the activities of such a powerful financial institution. As scholar-activist Susan George notes, while those with "wealth and power are in a better position to hide their activities and are therefore more difficult to study, any knowledge about them will be valuable to 
movements for social justice ... Better a sociology of the Pentagon or the Houston country club than of single mothers or L.A. gangs" (as cited in Robinson, 2014, p. 215). While I have done my best to examine the information at hand, I should note that this dissertation is not an attempt to uncover a secret history of the bank, but rather, that which can be plainly seen in their own corporate documents and the business press. I do not need to make my argument on the basis of such material and would — very much, in fact—argue the opposite; that much of today's epochal-level change is happening right before our very eyes. The constant fascination with that which is secret (something oft-suggested to me by my colleagues during the making of this dissertation) reminds me of an earlier quote by Jane Jenson (1989) who, in promoting a regulation approach to the study of Canada, argued that by the application of useful categories, "there is no need to force Canadian history, to find a single wartime public opinion poll or an entry in Mackenzie King's diary the evidence for class mobilization which resulted in a postwar settlement" (p. 88). In similar fashion, this dissertation takes the position that the conceptual and analytical framework used reduces the need to uncover such secret activities, as helpful as they may or may not be. In other words, what I attempt to provide in this dissertation is a new method of interpreting those events that can plainly be seen by anyone.

I should note, however, that during the research process there were a variety of sources examined that were not cited in the main text for various reasons. For the reader interested in such sources, I will include them here. Some of the more significant works include those on Canadian finance and banking (e.g., Armstrong, 1967; Armstrong \& Nelles, 1988; Binhammer, 1968/1988; Brennan, 2015; Buckley, 1974; Cameron et al., 
1991; Carr et al., 1995; Creighton, 1933; Crow \& Fischer, 2002; Daniel, 2002; Denison, 1967; Deneault, 2013; Eckardt, 1914; Freedman, 1998; Iacobucci et al., 2006; Jamieson, 1953; McIvor, 1958; Neufeld, 1958; Paterson, 1976; Patterson, 1932; Taylor, 1911); those on the history of the Royal Bank of Canada (e.g., Heron, 1969; Ince, 1970); and primary sources from the Royal Bank itself, such as the bank's Monthly Letter from 1943 to 2008, their Newsletter and Interim Report from 1976 to 1983, and their annual reports from 1966 to 2014. I also examined every single mention of the Royal Bank of Canada in the following newspapers: The Globe and Mail from 1844 to 2014; the Financial Times from 1888 to 2014; and the New York Times from 1851 to 2014.

Another note is required on naming conventions. Like many old corporations, the name of the Royal Bank of Canada has changed over time. It began as the Merchants Bank before turning into the Merchants Bank of Halifax. It was then changed to the Royal Bank of Canada before finally turning into simply RBC (or, depending on the unit, the suitably redundant RBC Royal Bank). In the text, I refer to whatever name the bank is during the time I am referring to it. I do note, however, when a name change has taken place as they are almost always significant to the changing contexts in which the bank has found itself.

Lastly, after much deliberation, I have decided to remove a number of 'scare quotes' around the terms national and global throughout the text. These quotes were initially used to signify that I was referring to something that was nominally national or global (or commonly referred to as such) but was not necessarily supporting national or global processes. In the end, however, I felt that this was too confusing for the reader and 
only ended up complicating matters. That said, this dissertation is an attempt to get us to stop thinking about the national and global as different scales, and rather, to think of them as different configurations as territory, authority, and rights; as such, the reader is warned in advance that my use of these terms is not simply indicative of the scale of operation.

\subsection{Chapter Outline}

The dissertation proceeds as follows. In the second chapter ("Some Canadian Reflections on Globalization and Financialization"), I provide an overview of the classical and contemporary theories of imperialism and dependency and reflect on their use in the Canadian context and their continuing relevance to the study of globalization. I focus on two changes associated with globalization that challenge the framework on which those theories are based: (1) the collapse of the Bretton Woods System in the 1970s, the emergence of new rights for financial institutions in the 1980s, and the effect of those rights on the ambiguity of the nationality of capital today; and (2) the wider movement of the rights of capital and the authority over those rights to the transnational level. I conclude by arguing that these changes necessitate some level of conceptual recoding if we are to grasp the character and nature of our present global epoch.

In the third chapter ("Property and Periodization: Thinking of Historical Property Regimes as Assemblages of Territory, Authority, Rights"), I present an alternative approach to globalization. After first highlighting the neglect of banking in Marxist political economy and some of the problems with using the mode of production to periodize, I use the work of Saskia Sassen to suggest that we start thinking of the national and the global 
as different assemblages of territory, authority, and rights. I conclude by noting how thinking in such a way can help us better register how the property relations of capitalism are changing and with what implications.

The fourth and fifth chapters explore the history of the Royal Bank of Canada and can be understood as an attempt to see how what we refer to as national capital was constructed. In the fourth chapter ("Making National Capital: The Origin of the Royal Bank of Canada, 1864-1939") I argue that the late 19th and early 20th century can be distinguished from our own by virtue of the creation of a national system of property relations; that is, by a centripetal organizing dynamic of TAR toward the national level. I identify four shifts in TAR - Confederation and the Bank Act, the National Policy, the Finance Act, and the Bank of Canada - to represent this drawing in as it relates to the chartered banks. I claim that the overall effect of this organizing logic was to provide the chartered banks with the capability to grow via both expansion and protection. As such, I conclude that we should understand this period of capitalism as the making of what is commonly called national capital.

In the fifth chapter ("The Expansion of National Capital: The Growth of the Royal Bank of Canada, 1940-1974") I continue this exploration of the history of the bank from 1940 to 1974 . I argue that this period represents the interregnum between the national and global epochs of capitalism. I make this argument on the basis that the period begins with a continuation of the centripetal organizing logic that characterized the earlier period of capitalism; that is, a continued drawing in of TAR to the national level. Despite increasing levels of global economic activity, the rights of capital and the authority over those 
rights remained primarily at the level of the nation-state, giving governments a number of options to regulate and control capital flows. I identify the Bretton Woods system as one indicator of this intensification. The relative success of this system in protecting national capitals would have the subsequent effect, however, of increasing competition among domestic financial institutions, leading many banks to escape national regulatory control via the Eurodollar markets, whose foreign currency flows would eventually overwhelm the Bretton Woods system. I conclude by arguing that the collapse of Bretton Woods represents the tipping point into our present global epoch by unleashing the power of financial capital.

The sixth chapter ("Making Global Capital: RBC in the Digital Age, 1975-2014") represents an attempt to understand where we are by continuing the exploration of the bank's history from 1975 to 2014. I highlight an emerging centrifugal dynamic of TAR that stands in stark contrast to the organizing logic of the national epoch of capitalism. I argue that this emerging logic gives us a small glimpse into a much larger transformation: the construction of a truly global system of rights for capital outside the grasp of national politics. I identify three shifts in TAR - the movement of authority over banking to supranational institutions, financial deregulation, and so-called free trade agreements - to represent this centrifugal dynamic as it relates to the chartered banks. I claim that the overall effect of this organizing logic is to provide globalizing capitals (including what were formerly national capitals) with the capability to grow and expand by restricting the power of the nation-state to legislate against anything that might impact the accumulation 
of capital. As such, I conclude that we should understand our present period as a new historical epoch that consists of the making of global capital.

The seventh chapter ("Emergent Trends and Implications") is an attempt to understand where we are going by extending my analysis of the Royal Bank of Canada into the future to explore some emergent shifts in TAR and their potential implications. In particular, I focus on new forms of escape from the nation-state, such as dark pools and temporary foreign worker programs (TWFP); new free trade agreements, such as the Comprehensive Economic and Trade Agreement (CETA), the currently stalled Trans-Pacific Partnership (TPP) and the Trade in Services Agreement (TiSA); and new so-called 'institutional technologies,' such as the blockchain. I argue that while the full effect of these shifts in TAR is still unknown, they all contribute to the development of a global property regime in which the nation-state is increasingly limited as to what actions it can take against corporate interests. I conclude by highlighting some positive aspects of these developments that could potentially provide the institutional basis for a more sustainable, post-capitalist future.

In the final chapter ("Conclusion"), I conclude the dissertation by reflecting on the research process, the limitations of my dissertation, areas for future research, and the practical implications of my research. I finish by reflecting on the importance of property for social analysis. 


\section{Some Canadian Reflections on Globalization and Financialization}

It will be my thesis in these few remarks to say that not only does capital have no nationality but, indeed, it may be supra-national as it flows between countries. However, it certainly becomes an integral part of the nation once it comes to rest, which is to say, once it has been invested in the host country.

-Robert W. Bonner, Q.C., Executive VicePresident, MacMillan Bloedel Limited, 1970.

\subsection{Introduction}

The first theories of imperialism were an attempt to explain the wave of financial ascendency that spanned the last quarter of the 19th century until the interwar years. As Lapavitsas (2013) notes, over that period, "giant monopolistic corporations [referred to as monopoly capital] emerged as the dominant units of production, often organized as cartels operating in exclusive trading zones" (p. 44). As well, capital exports increased and international financial markets grew larger and more powerful, with the help of "monopolistic banks that dominated global finance" (p. 44). As British supremacy in the spheres of production and commerce came under challenge from Germany and the United States, militarism and colonialism reigned among the leading capitalist powers as they attempted to divide the world among them.

Given that our current period has many similarities to the first, it is not surprising to find many scholars treating globalization as a new form of imperialism (e.g., Bromley, 2003; Callinicos, 2009; Foster, 2003; Harvey, 2003a; Norfield, 2016; Panitch \& Gindin, 2012; Smith, 2016a; Wood, 2003). Lapavitsas (2013) notes, for instance, that:

multinational corporations dominate global economic activity; global banks play a leading role in international finance; capital exports have grown substantially; a 
certain type of political and military imperialism has reasserted itself, led by the U.S. but facing powerful challenges from other powers (p. 44).

But there are important differences too. Our present period is not characterized by "exclusive trading zones associated with territorial empires, and banks are not dominant over non-financial enterprises" (p. 56) despite the depth and extent of financialization today. These differences have led another group, often referred to as the global capitalism school, to argue that globalization is not merely a resurgence of imperialism, but rather, an entirely novel epoch within the history of world capitalism (e.g., Demirović, 2011; Hardt \& Negri, 2000; Harris, 2005; Liodakis, 2010; Robinson, 2004, 2014; Sklair, 2001; Sklair \& Robbins, 2002).

These debates are of particular importance in Canada, where political economists, sociologists, and political scientists have long struggled to explain Canada's 'location' within the global political economy. As I noted in the introduction, all parties to this debate base at least some part of their claim on the strength of Canada's small, but incredibly powerful, banking sector. Where dependency theorists see the chartered banks as being partly responsible for the country's truncated development by virtue of their sectoral orientation toward the staples trade (e.g., Drache, 1977; Levitt, 1970; Lumsden, 1970; Naylor, 1975/1997; Teeple, 1972), imperialist theorists see the power of the banks as representing what Rudolph Hilferding (1910/1981) referred to as 'finance capital,' the amalgamation of financial and industrial capital, and thus, the country's independent status (e.g., Carroll, 1986; Kaufman, 1985; Moore \& Wells, 1975; McNally, 1981; Niosi, 1985; Resnick, 1982; Veltmeyer, 1987). 
On both sides, the major claims rest on the question of who owns Canada's productive capital. If foreign interests own Canada's productive capital (as a result of the mercantile-financial character of Canada's ruling class) then Canada can be understood to be a dependent social formation. If Canadian capitalists own Canada's productive capital in the form of finance capital, however, then Canada (according to imperialist theorists) can more accurately be typified as a secondary imperialist power. Revived recently in the context of globalization and financialization, these debates continue to 'place' Canada on the basis of whether Canadian or foreign capital rules the domestic market (e.g., Albo \& Klassen, 2013; Carroll, 2012; Burgess, 2000, 2002; Deneault \& Sacher, 2011; Gordon, 2011; Hurtig, 2003; Ikeda, 2004; Kellogg, 2005, 2009, 2015; Klassen, 2008, 2009, 2014; McQuaig, 2007; Seccareccia, 2007; Stanford, 2008, 2014; Watkins, 2007).

At no point in this debate, however, has there been any inquiry into whether globalization and financialization have fundamentally transformed the basic units on which these theories are based. For all of their various positions and the changing historical conditions on which they rely, all theories of imperialism and dependency put forward a vision of the global political economy as constituted by rival national capitals and their respective nation-states. In this chapter, I highlight two qualitative changes to the property relations of capitalism that problematize this framework: (1) new rights granted to financial institutions in the 1980 s that have subsequently made it essentially impossible to identify the nationality of capital, significantly challenging theories whose claims are based on such evidence; and (2) new rights for corporations at the transnational level that restrict the nation-state from crafting policies that limit the accumulation of capital by 
foreign entities, troubling the idea, inherent to such theories, that nation-states act on behalf of their national capitals. As such, I argue that some level of conceptual recoding is necessary to grasp the character and nature of our emerging global epoch, as well as Canada's experiences with globalization.

The chapter proceeds as follows. After first reviewing the various theories of imperialism and dependency as they have transformed over the 20th century, I focus more specifically on the ways in which these theories have been applied to the analysis of Canadian development. I then explore how the deregulation of finance in the 1980s has worked to blur the lines of corporate nationality and how so-called free trade agreements force nation-states to act on behalf of foreign capitals. I argue that these novel political and economic developments problematize the extent to which our current period can be captured through the conceptual framework of imperialism and dependency. I conclude by suggesting that if we want to better understand the qualitatively novel aspects of our current epoch, we need a new conceptual framework that will allow us to move from the macro-sociological level of the global political economy back down to the specific activities of Canadian firms, such as the chartered banks. Doing so, I claim, will allow us to comprehend just how much the terrain of action on which capitalist activity unfolds has changed over time, as well as the implications.

\subsection{Theories of Imperialism and Dependency}

The economist John Weeks (1991) notes that: "of all the concepts in Marxist theory imperialism is perhaps the one used most eclectically and with the greatest disregard 
for the theoretical basis upon which it rests" (p. 252). As Brewer (1980/2002) points out: "Marx did not use the word 'imperialism,' nor is there anything in his work that corresponds at all exactly to the concepts of imperialism advanced by later Marxist writers" ( $p$. 25). Originally used by such writers to refer to the process of capital accumulation on a world scale in the era of monopoly capitalism, the concept has since become "synonymous with the oppression and 'exploitation' of weak and impoverished countries by powerful ones" (Weeks, 1991, p. 252). Indeed, as political scientists Shimshon Bichler and Jonathan Nitzan (2012) note, the concept of imperialism, like financialism, has "changed more or less beyond recognition" (p. 43). As such, it is necessary to provide a brief review of the various theories of imperialism and dependency before reflecting on their use in the Canadian context and their relevance to the study of globalization. To do this, I draw heavily on two reviews of this literature produced by Bichler and Nitzan (2006, 2012). ${ }^{2}$

The classical theories of imperialism were an attempt to explain the phenomenon of colonialism and the emergence of war among the capitalist powers in the late 19th and early 20th centuries. The earliest was produced by British left liberal John A. Hobson (1902/2005) who viewed imperialism as a regrettable, but ultimately rational, policy program pursued by advanced nation-states as a result of overproduction by capitalist enter-

2 I draw heavily on these reviews because they do an excellent job of demonstrating both the ways in which the various theories are constructed, as well as the ways in which they have transformed over time. Outside of the primary literature itself, I also consulted reviews by Brewer (1980/2002), Kay (1989), So (1990), and Robinson $(2007,2011)$. 
prises in the face of a limited domestic market. ${ }^{3}$ This idea was expanded upon by later Marxist writers such as Rudolph Hilferding (1910/1981), Rosa Luxemburg (1913/2003), Karl Kautsky (1914/1970), Vladimir Lenin (1917/1999), and Nikolai Bukharin (1917/1929), who saw imperialism as the inevitable outcome of a new stage in capitalism in which capital had become concentrated in huge national financial-industrial combines dominated by bankers, and referred to as finance capital. The basic argument was that the 20th century marked the turning point from "the old capitalism to the new, from the domination of capital in general to the domination of finance capital" (Lenin, 1917/1999, p. $57)$.

As Bichler and Nitzan (2012) note, despite their differences, the classical theorists all agreed that this transformation of capitalism had two significant implications. The first was that the concentration and "centralization of capital in the hands of the large financiers made the distribution of income" (p. 44) within states far more unequal. As inequality grew, the purchasing power of domestic workers was restricted "relative to the productive potential of the system" (p. 44), leading to the creation of surplus capital "that could not be invested profitably in the home market" (p. 44). This subsequently forced capitalists abroad to find new, mainly "pre-capitalist regions" (p. 44) for investments. The second was that as capital centralized, it transformed the the nation-state away from "the night-watchman government of the laissez-faire epoch" (p. 44), toward a strong version

3 It is important to note that Hobson did not view imperialism as an inevitable characteristic of advanced capitalist nation-states. As a social democrat, he saw imperialism as a policy decision, meaning that it could be replaced by benevolent policies aimed at developing the domestic market through increased wages and social benefits. This is in contrast to Marxist writers, who saw imperialism as part and parcel of the growth and expansion of capital. 
active in international affairs (p. 44). The idea was that the "oligarchy of 'finance capital' - a coalition of large bankers, leading industrialists, war mongers and speculators" (p. 44) - that now dominated the state, required a strong version that could "crack down on domestic opposition and embark on foreign military adventures" (p. 44). As Hilferding (1910/1981) put it: "all capitalists with interests in foreign countries call for a strong state whose authority will protect their interests even in the most remote corners of the globe" (p. 322). And since the type of financialized economy engendered by centralization requires pre-capitalist colonies to reinvest surplus capital, the classical Marxist theorists argued that the nation-state was increasingly pushed into an international imperialist struggle to obtain more colonies. The main reason for this was explained by Hilferding (1910/1981) who argued that export capital felt most comfortable when its own state was "in complete control of the new territory, for capital exports from other countries are then excluded, it enjoys a privileged position, and its profits are more or less guaranteed by the state" (p. 322). Lenin (1917/1999) put it similarly a few years later writing that the process of centralization consists of "the strengthening of state power within each of the 'advanced' capitalist countries and its use to further the interests of finance capitalists of its own country on the world market" (p. 13). As Bichler and Nitzan (2012) note, this was the emergence of "the nexus between imperialism and financialism" (p. 44); in other words, the theoretical link between the rise of financialization and the export of capital, which subsequently "encourages an imperialist policy" (Hilferding, 1910/1981, p. 322). The conceptual framework as set out in the classical Marxist theories of imperialism is thus one in which the global political economy is "divided by different 
ruling classes, whose power is represented by the state of each country" (Weeks, 1991, p. 253).

As Bichler and Nitzan (2012) note, new political and economic realities led later theorists to transform the theory of imperialism (p. 44). Since the socialization of banking characteristic of Hilferding's Germany (and on which finance capital is based) did not happen in other countries, both the theory of imperialism, as well as its basic categories, were altered to match with the new circumstances of the day. ${ }^{4}$ As Bichler and Nitzan (2012) argue, by the end of the Second World War, the military and economic pre-eminence of the United States alongside the emergence of a nominally socialist rival in the Soviet Union had the effect of reducing inter-capitalist conflict between the core powers, which changed the character of international conflict substantially (p. 45). Inter-capitalist wars were thus replaced by "a Cold War between the former imperial powers and the United States on the one hand and the Soviet bloc on the other" (p. 45). Expensive forms of direct colonial control also "gave way to decolonization, while tax-collecting navies were replaced by the more sophisticated tools of foreign aid and foreign direct investment" (p. 45). In many capitalist countries, the nation-state was also transformed into

4 As Lapavitsas (2013) notes, the concept of finance capital is problematic because Hilferding generalized his analysis of Germany's system of industrial banks. In most countries, however, this sort of merger between financial and industrial capital did not occur. While the concept can be used to describe some of the organic and institutional links between industrial and financial capital, Lapavitsas (2013) concludes that "finance capital does not capture the complexity and range of relations between industrial and banking capital in the course of the twentieth century" (p. 60). A similar point has been made by Harris (1991) who notes that "the power of the banks within the capitalist system is not primarily the consequence of their direct involvement in and control of industry even though that involvement does exist. It arises from the structural power that their (and other) financial capital exerts in the foreign exchange and money markets, determining interest and exchange rates that influence the whole economy. It also arises from the discretionary power private banks have acquired to move credit on an international scale, but this credit is financial capital not bank capital tied to industry; it was exemplified in the 1970s by the international banking system becoming the principal source of credit for some third world and socialist governments, a position that gives them great power but does not constitute finance capital" (pp. 202-203). 
some variation of "a large welfare-warfare state whose 'interventionist' ideologies and counter-cyclical policies managed to reduce instability and boost domestic growth" (p. 45).

Although these various transformation represented changed conditions from the "finance-driven imperialism" (Bichler \& Nitzan, 2012, p. 45) of the earlier theories, later Marxist writers simply opted to redefine the term. Bichler and Nitzan (2012) argue that this "revised link was articulated most fully by the Monopoly Capital school associated with the New York journal Monthly Review" (p. 45; e.g., Kalecki, 1971; Steind1, 1952; Baran, 1957/1962; Baran \& Sweezy, 1966; Magdoff, 1969; Sweezy \& Magdoff, 1972). The Monopoly Capital school argued that capitalism remained "haunted by a lack of profitable investment outlets" (Bichler \& Nitzan, 2012, p. 45) and that, as a result of the "shift from competition to oligopoly" (p. 45) that Marx's labour theory of value and surplus value "had become more or less irrelevant to capitalist pricing" (p. 45). The Monopoly Capital school argued that in an oligopoly, technical change and efficiency gains predominate, "making commodities cheaper and cheaper to produce" (p. 45). ${ }^{5}$ As a result of the lack of market discipline, however-which, "forces firms to pass on their lower costs to consumers" (p. 45) - the reduction in the cost of production does not translate into falling prices, but rather, increases the income share of capitalists (p. 45). ${ }^{6}$ As Bichler and Nitzan (2012) note, the Monopoly Capital school thus saw this transition as reversing

5 The argument is "not that monopolies slow down technical change in the long run, but that they will introduce new techniques less wastefully and thus with less investment" (Brewer, 1980/2002, p. 140).

6 Brewer (1980/2002) makes a similar observation of the Monopoly Capital school's position, noting that under monopolistic conditions, a firm "will not expand output because it would have to cut prices to sell more, reducing its profits" (p. 139). 
the underlying trajectory of capitalism (the tendency for the rate of profit to fall due to mechanization and competition), thereby causing the surplus to rise (pp. 45-46).

Where the classical Marxist theorists of imperialism saw the solution to rising surplus (from the perspective of the capitalist) in external terms-exporting surplus goods and capital to be "invested in pre-capitalist colonies" (Bichler \& Nitzan, 2012, p. 46) — the Monopoly Capital school argued that it could also be "wasted at home" (p. 46). ${ }^{7}$

Bichler and Nitzan (2012) note that while this waste came in a variety of forms such as mass consumption and planned obsolescence, the most significant were spending on the military and financial sectors due to "their seemingly limitless size" (p. 47). ${ }^{8}$ Since any surplus could simply be pumped back into these two sectors, the Monopoly Capital school claimed that they were able to "suck in large chunks of the excess surplus without generating any excess surplus of their own" (p. 47). Now unencumbered by inter-capitalist wars, American multinational corporations (MNCs) were thus able to use the United States' strengthened military and financial sectors to secure an "international division of labour, free access to strategic raw materials and political regimes that are ideologically

7 Brewer (1980/2002) provides a concise summary of Baran's theory of monopoly: "Monopoly, he argued, leads to restriction of output and investment, and hence to low growth (in all parts of the world). In advanced countries output is high, and high monopoly profits depress workers' consumption, so there is a chronic shortage of demand (this is almost identical to Hobson's argument). In underdeveloped countries the 'surplus' is partly absorbed by the luxury spending of the ruling class, but much of it is transferred to the advanced countries (as profits), where it contributes to the problem of absorbing the rising surplus. Monopoly thus transforms capitalism from a force for development into a cause of stagnation, both in advanced and in underdeveloped countries. In underdeveloped countries, however, there was no competitive stage, so they are 'frozen' at a low level of production and income" (pp. 2122).

8 Brewer (1980/2002) provides a similar interpretation: "state spending absorbs large chunks of the potential surplus in various wasteful ways, notably through military spending . . Military spending, with related forms of expenditure, such as spying, military aid to allies, and so on, emerges as one of the few forms of state spending which can absorb the surplus without harming the interests of any powerful fraction of the ruling class. Military spending is, in Baran's analysis, intimately tied up with imperialism" (p. 147). 
open for business" (p. 47), thereby enabling the United States to dominate and exploit "to one extent or another all the countries and territories of the so-called "free world"" (Baran \& Sweezy, 1966, p. 365). Massive spending on these expanded sectors was therefore not only a means of absorbing surplus, but of securing "a more sophisticated and effective neo-imperial order that no longer needs colonial territories but is every bit as expansionary, exploitative and violent as its crude imperial predecessor" (Bichler \& Nitzan, 2012, pp. 47-48). As Sweezy and Magdoff (1972) put it: "the most extravagant and unparalleled use of financial power for control over other parts of the world is that exercised by the United States since the Second World War" (p. 228).

The postwar expansion of American MNCs around the world, alongside increasing American military and diplomatic interventions in Latin America and the Caribbean, led other Marxist authors to focus more explicitly on the imperial core's continual subjugation of the periphery. These dependency theories emerged as a critique of liberal modernization theories, which argued that "Third World countries should follow a path [of 
development] similar to that of the advanced capitalist countries" (Kay, 1989, p. 7). ${ }^{9}$ Taking the language of 'core' and 'periphery' (or metropolis and satellite, among other variations) from Latin American structuralism and combining it with the Monopoly Capital school's earlier insight that the periphery's initial underdevelopment was the result of Western European colonialism, ${ }^{10}$ the dependency theorists argued that the underdevelopment of postcolonial countries would continue insofar as capitalism, and the unequal system of exchange on which it was based, remained in place (Amin, 1974; Cardoso and Faletto, 1979; Emmanuel, 1972; Frank, 1966, 1967). This idea was quickly expanded into a theory of 'world-systems' by the development sociologist Immanuel Wallerstein

9 Dependency theories emerged out of the structuralist development theories produced by the United Nations' Economic Commission for Latin America and the Caribbean (ECLAC); in particular, the work of Raúl Prebisch (1950), Hans Singer (1950), and Celso Furtado (1961, 1967), although the latter had left ECLAC by the time his major works were created (Kay, 1989, p. 28). The structuralist argument is essentially one of unequal exchange; in other words, that primary commodity-exporting countries (i.e., the periphery) typically end up suffering from deteriorating terms of exchange with wealthy, manufactured goods-exporting nations (i.e., the core). This unequal relationship thus cancels out the benefits of comparative advantage and perpetuates the underdevelopment of peripheral countries. To create the conditions for national development, the structuralists "proposed to replace the externally propelled development path inherited from the colonial period with an inward-directed development strategy on the basis of an import-substituting industrialization process. To bring about, or accelerate, such a shift structuralists called for a far greater role for government in development. The structuralist scenario implied a developmentalist state which actively intervened in the economy and the market through planning. protective tariffs for industry, price controls, state investment, joint ventures with foreign capital, the establishment of regional common markets, and so on" (p. 21). Marxist dependency theorists are critical of structuralism for not advocating for "the nationalization of major foreign-owned primary commodity-producing and commodity-exporting companies" (p. 21). They are also critical of orthodox Marxism, for its view that capitalism leads to convergence. As Marx and Engels (1848/1978a) write in The Communist Manifesto: "National differences and antagonisms between peoples are daily more and more vanishing, owing to the development of the bourgeoisie, to freedom of commerce, to the world market, to uniformity in the mode of production and in the conditions of life corresponding thereto" (p. 488). Marx (1867/1978a) also writes in the "Preface to the First German Edition" of the first volume of Capital that: "the country that is more developed industrially only shows, to the less developed, the image of its own future" (p. 296).

10 Baran (1957/1962) notes, for example, that: "Western European visitors rapidly determined to extract the largest possible gains from the host countries, and to take their loot home. Thus they engaged in outright plunder or in plunder thinly veiled as trade, seizing and removing tremendous wealth from the places of their penetrations. 'In the cruel rapacity of its exploitation colonial policy in the 17th and 18th centuries differed little from the methods by which in earlier centuries Crusaders and the armed merchants of Italian cities had robbed the Byzantine territories of the Levant.' And 'the treasures captured outside Europe by undisguised looting, enslavement and murder flowed back to the mother-country and transformed themselves into capital"” (p. 274). 
(1974/2011). Influenced by the Annales school's long term approach to the study of history (e.g., Braudel, 1949/1995, 1979/1992a, 1979/1992b, 1979/1992c), world-systems theory attempted to map the hierarchy of political relationships alongside the global "division of labour, and flow of commodities and surplus between the peripheral countries at the bottom, the semi-peripheral satellites in the middle and the financial core at the apex” (Bichler \& Nitzan, 2012, p. 49). Despite significant differences from the earlier theories of imperialism, these updated theories retained a view of the global political economy as constituted by rival nation-states 'acting' on behalf of 'their' national capitals. ${ }^{11}$ In attempting to take into account many of the changes occurring in the world economy, however, such as the rise of the East Asian economies, the crisis of socialism (i.e., the Sino-Soviet split, the failure of the Cultural Revolution, and the opening of socialist states to capitalist investment), and the crisis of North American capitalism (i.e., the Vietnam War, Watergate, the oil embargo, rising inflation [Bichler \& Nitzan, 2012, p.

11 Immanuel Wallerstein (2004) makes this clear this when he writes that: "states are by definition rivals, bearing responsibility to different sets of rival firms" (p. 56). As Robinson (2011) notes, Wallerstein often goes further by referring "to states, and even to the world-system, as if they were conscious macro agents" (p. 737). Where the earlier Marxist theories of imperialism emphasized "the centrality of exploitation in production, dependency and World-Systems analysts shifted the focus to trade and unequal exchange ... [and thus] conflict between states and geographical regions" (Bichler \& Nitzan, 2012, p. 49). As Robinson (2011) notes, this is because dependency and world-systems theories define capitalism, following Weber, "as a market or exchange relation whereas Marx defined ... [it] as a relation of production" (p. 734; see also, Brenner, 1977). As a result of the focus on exchange relations, there is an explicit lack of theorizing in these approaches as to the ways in which changes to property, class, and class conflict at the national level relate to the larger, world capitalist system. As Theda Skocpol (1994) notes in a popular critique: "To be sure, markets and patterns of trade are bound to be part of the picture, but it seems unlikely that they can be understood in their origin, functioning, or effects except with reference to changes in class and political structures. The alternative picture of world capitalism that is likely to emerge from historical analyses pursued along these lines will probably pertain to intersecting structures (e.g., class structures, trade networks, state structures, and geopolitical systems) involving varying and autonomous logics and different, though overlapping, historical times, rather than a single, all-encompassing system that comes into being in one stage and then remains constant in its essential patterns until capitalism as a whole meets its demise" (p. 67). Teeple (2000) similarly points out that these approaches end up reifying the "international capitalist trading system, giving it an autonomous reality separate from the historically developing national capitals that have constituted its parts" (p. 172). 
50; So, 1990, pp. 46-49]), world-systems theory quickly became a theory of hegemonic decline.

Despite variations on this theme (Arrighi, 1994/2010; Wallerstein, 1984), theories of hegemonic decline all share a common template in which "the maturation of the hegemonic power-be it Holland in the seventeenth century, Britain in the nineteenth century or the United States presently — coincides with the 'over-accumulation' of capital" (Bichler \& Nitzan, 2012, p. 50). The growth of the financial sector-"marked by soaring capital flows, a rise in market speculation and a general inflation of debt and equity values" (p. 51) - is thus portrayed by these theories as an attempt by the leading hegemon to prevent its decline. ${ }^{12}$ But since the financial sector also ends up hollowing out the productive capabilities of the hegemon, it "causes productive investment to flow elsewhere and eventually sets in motion the immanent process of hegemonic transition" (p. 51). ${ }^{13}$ As Bichler and Nitzan (2012) point out, despite the universal narrative, the inspiration for these theories is "drawn from the apparent 'financialized decline'

12 As Bichler and Nitzan (2012) note, in returning to the classic Marxist distinction between industrial activity as productive (i.e., something that generates surplus value) and commercial and financial activity as unproductive (i.e., something that does not generate surplus value, but rather, siphons it off from other circuits), theories of hegemonic decline began to argue that while financialization might "help the imperial core absorb its rising surplus" (p. 50), it does so at its own peril: "it hollows out the core's industrial sector, it undermines its productive vitality, and, eventually, it limits its military capability" (p. 50). In such theories, the financial sector continues to expand until it eventually explodes, taking the reigning hegemon down with it (p. 50).

13 These theories take their influence from Braudel (1979/1992c), who writes that "every capitalist development of this order seems, by reaching a stage of financial expansion, to have in some sense announced its maturity: it was a sign of autumn" (p. 246). Arrighi (1994/2010), for instance, writes: "Throughout the capitalist era financial expansions have signalled the transition from one regime of accumulation on a world scale to another. They are integral aspects of the recurrent destruction of 'old' regimes and the simultaneous creation of 'new' ones" (p. xii). Furthermore, like other theories of imperialism, he makes clear that this takes place within a framework of competing national states: "interstate competition has been a critical component of each and every phase of financial expansion and a major factor in the formation of those blocs of government and business organizations that have led the capitalist world-economy through its successive phases of material expansion" (p. 13). 
of U.S. hegemony" (p. 51; see, e.g., Arrighi, 1994/2010; Arrighi \& Silver, 1999). These theories argue that the United States has been increasingly 'depleted' since the 1970s as a result of increased military spending alongside "rising debt and bloated financial intermediation" (Bichler \& Nitzan, 2012, p. 51). As such, they argue that the United States "has imposed its own model of 'financialization' on the rest of the world, hoping to scoop the resulting expansion of liquidity" (p. 51). Whether replicating the model in their own countries, or financing it by purchasing American assets, all nation-states, according to theories of hegemonic decline, "have been pulled into an unprecedented global whirlpool of capital flow" (p. 51).

These theories of hegemonic decline have more recently been accompanied by theories of new imperialism which attempt to explain the Iraq War and other recent conflicts by arguing that globalization represents a new stage of inter-imperialist rivalry (Arrighi, 2005; Foster, 2003; Callinicos, 2009; Desai, 2013; Harvey, 2003a; Wood, 2003). In their review of this body of literature, Nitzan and Bichler (2006) note, for instance, that Ellen Meiksins Wood (2002b) treats globalizations as "the economic imperialism of capital" (p. 25) with the United States playing the role of hegemon: "global capital's ultimate coercive power" (p. 26). Unlike the old style imperialism, which was constituted by formal colonies, Wood (2002b) claims that globalization "depends more than ever on a system of multiple states" (p. 24; Bichler \& Nitzan, 2012, p. 7; Wood, 2002a). And since many nation-states are not well integrated into the global capitalist system, there remains a need for the imperial power (the United States) to engage in constant "displays of military force" (p. 25) in order "to demonstrate US hegemony" (p. 26) over unruly states at- 
tempting to "oppose the will of imperial capital" (p. 24). Nitzan and Bichler (2006) also highlight the work of David Harvey (2003b), who believes that the United States "lost its superiority in production after 1970 and may well now be losing financial dominance, leaving it with military might alone" (pp. 82-83). They note that Harvey's major claim is that globalization is a 'spatio-temporal fix' for the overaccumulation of capital amongst the core powers (Nitzan \& Bichler, 2006, p. 10). ${ }^{14}$ The Iraq War, amongst other conflicts in the Middle East, are portrayed by Harvey (2003b) as an American attempt to "control oil supplies as a means to counter the power shifts threatened within the global economy" (pp. 80-81). While the United States retains military dominance, theories of new imperialism see it as quickly losing its financial position at the top of the pyramid as a result of the rise of China.

Others disagree that globalization represents the decline of American hegemony (Gowan, 1999; Panitch \& Gindin, 2005, 2012). Leo Panitch \& Sam Gindin (2012), for instance, argue that free trade and imperialism are not contradictory, as the classical theories suggested, but rather, constitute a form of informal empire that relies heavily on state intervention; in particular, on the capacities of the dominant state to maintain and reproduce their imperial position. They use the example of the transformation of export capital after 1945 to demonstrate how the American state increasingly took responsibility (albeit, begrudgingly, in many cases) for creating the political and juridical conditions for the global extension and reproduction of capitalism, including: constructing international in-

14 As Nitzan and Bichler (2006) note, this term was "invented to describe geographical expansion into previously noncapitalist areas and forms of reproduction on the one hand, and long-term, mainly infrastructural investments on the other" (p. 10). 
stitutions in their own image; providing capital to competitor states on the basis of equal treatment to all capitals; the incorporation of foreign capitalists into the American empire; the many legal changes that made today's global financial system possible; and the continuing management of an unstable global economic system. Against the view that the 2008 financial crisis signalled the decline of American hegemony, Panitch and Gindin (2012) argue that it was instead a case of America sharing its problems with the world, itself evidence of the depth and extent of America's informal empire. ${ }^{15}$

Still others are not convinced that the global political economy consists solely of competition between national capitals and nation-states at all. Following from Kautsky's (1914/1970) theory of ultra-imperialism, theorists of collective imperialism argue that globalization is characterized more by cooperation by the leading capitalist powers than by competition (e.g., Bromley, 2003; Cammack, 2003; Carroll, 2012, 2013; Willoughby, 1995). They do not deny the significance of competition, but argue that the only way in which capitalists are able to maintain global hegemony is by colluding, rather than competing: "in an ultra-imperialist world, each gains by co-operating with the other, even if the sharing of the gains is uneven" (Bromley, 2003, p. 26). While theories of collective imperialism still see the United States as having a directive role within the hierarchy of capitalist powers, they argue that there are collective benefits that flow to those nationstates who partake in forms of imperial coordination.

Despite their many differences, these contemporary theories of imperialism and dependency all tend to share the view that globalization represents some form of return to

15 For a close critique of this interpretation, see Garrod (2015). 
the conditions of the earlier stage of imperialism and financialization that characterized the late 19th and early 20th centuries. As Porter (2005) notes: "this is not surprising, since the globalization of finance is a key aspect of globalization, and indeed is often taken to be the quintessential case or driving force of globalization" (p. 13). Like their classical counterparts, the contemporary theorists continue to see the global political economy as made up of competing nation-states that act on behalf of their national capitals. This is why they often prefer the label MNC as opposed to TNC (e.g., Anievas, 2008, p. 196; Panitch \& Gindin, 2012, p. 112) and are skeptical of claims that nation-states are being transformed or transcended by transnational capital. They frequently argue that nationstates are not victims of globalization, but rather, "its authors and enforcers" (Panitch \& Gindin, 2005, p. 101) and that "global capitalism is more than ever a global system of national states" (Wood, 2002a, p. 25). They all believe that globalization is not so much a stage, period, or phase, but rather, something that is inherent to the expansionary logic of capital itself. Tabb (2009) writes, for instance, that: "the most significant features of what is called globalization have always been part of capitalist development, even if the forms are different in different periods (including our own)" (p. 1). In the view of these modern theorists, since the earlier stage of imperialism was also characterized by financialization, globalization is simply more of the same; in other words, the most recent version of a pre-existing tendency.

The main problem, however, is that in none of these theories is there any attempt to discuss how states (or types of state) are made and transformed over time. For all their various positions and the changing historical conditions on which they rely, they all put 
forward a relatively similar vision of the global political economy as constituted by rival national capitals and their respective nation-states. In other words, they all assume the existence of an immutable, territorial state system in which rival states exist (and have always existed) in unequal relationships with other states. Nowhere do they ask: What is a state? How are they made? How are they changing? As sociologist William Robinson (2007) notes, the failure to ask these types of questions forces theories of imperialism and dependency into a rather sticky situation (as, for example, when they try to explain free trade as a form of imperialism):

If one starts with the theoretical assumption that the world is made up of independent, territorial-based nation-states and that this particular institutionalpolitical form is something immanent to the modern world ... then the changing world of the 21 st century must be explained by theoretical fiat in these terms (p. 16).

That they must explain the changing world of the 21 st century in this way is because to them the 21 st century is not changing - at least, not all that much. To these theorists, globalization is merely an ongoing and evolving feature of capitalism that begins from earlier networks of commerce and trade. Wallerstein (2000) provides an example when he writes: "globalization is a misleading concept, since what is described as globalization has been happening for 500 years" (p. 251). If globalization is nothing new then, by definition, it cannot be transforming the global political economy. These issues tend to be compounded when these theories are used to explain the 'place' and actions of specific nation-states. Theories of imperialism and dependency, for instance, are still one of the 
most popular ways of explaining Canada's 'location' in the world economy, and thus, the various actions of the Canadian state. As I demonstrate below, however, globalization involves a number of qualitative shifts that trouble this conceptual framework. Before discussing these shifts, let us first review the various ways in which these theories have been applied to Canadian development.

\subsection{Debates in Canadian Political Economy}

In the previous section I demonstrated that the classical theories of imperialism established a conceptual framework of rival national capitals and nation-states that has since been carried on and modified through the end of the 20th century via theories of imperialism, dependency, and world-systems, radical international relations theory, and studies of American intervention, among others. These theories have been very influential in Canada, where scholars have long struggled to explain the country's 'location' within this framework. ${ }^{16}$ "The first question which any political economist has to answer," writes Paul Kellogg (2009), is "whether Canada is part of the world system which benefits from the domination of other economies, or is an economy which suffers from domination" (p. 88).

Disagreements over the answer to this question have been ongoing since Mel Watkins (1963/1984) first published the "Staples Theory of Economic Growth.” Reviving

16 The literature covered in this section is explicitly confined to the debate over Canada's 'location' in the global political economy. There is other research, however, that explores Canadian development more closely on the basis of the relationship between internal and external factors (e.g., Brodie, 1990; Jenson, 1989, 1991). While useful and insightful, this research falls outside of the main debates and is thus left out of a more comprehensive treatment. In the future, I plan to engage with this work more directly, but for now the reader can begin with Smardon's $(2010,2011)$ worthwhile critique of the regulation school's periodization schema. 
Harold Innis' (1930/1999, 1940/1978) staples theory of development, the publication of Watkins' article and the results of his 1968 report on foreign ownership in Canadian industry ("The Watkins Report") spurred on the creation of a new generation of Canadian political economists in the 1970s: the New Canadian Political Economy (NCPE). Made up of Kari Levitt (1970), R.T. Naylor (1972), and Daniel Drache (1977), among others, they combined some of the insights of the staples tradition with particular aspects of Marxist theory to argue that Canada's relative underdevelopment (as compared to the United States) could be explained by historically high level of foreign direct investment (FDI) and an export-led growth strategy. Called simply dependency theories in Canada, they all shared the view that Canada's reliance on the export of staples and branch-plant manufacturing was the result of a historically dominant mercantile-financial ruling class whose interests ran counter to the development of local industry. They argued that this had led to an economy characterized by low productivity and technological imports, in which U.S. firms received most of the benefits. As British portfolio capital gave way to American direct investment in manufacturing after the First World War, they argued that Canada should be understood, at best, as an underdeveloped country on the periphery of the American empire. They claimed that the solutions to these problems were to be found in government policies focusing on "greater economic self-reliance" (Laxer, 1983, p. 192).

Arguably the most dominant interpretation within Canadian political economy, dependency theory still has many supporters. Watkins (2007) and Stanford (2008, 2014), for instance, have recently argued that Canada's increasing reliance on the export of pe- 
troleum products constitutes a new staples trap that could lead to increasing levels of deindustrialization and foreign takeovers, if not total global collapse:

Bitumen is what economic historians have come to call a superstaple, with an impact bordering on the monocultural. For the New World, the dark side of cotton and sugar was slavery, with horrifying global consequences. For bitumen it is extreme climate change and its catastrophic consequences for the wellness of the world and of all of its species (Watkins, 2014, p. 128).

Mel Hurtig (2003) has also written that Canada is a vanishing country that is sleepwalking into the American empire. Others similarly claim that Canada is a weak power "in a core-periphery relationship with the United States (Seccareccia, 2007, p. 236); that "longstanding structural problems, such as excessive resource dependency and the underdevelopment of a sophisticated 'knowledge-based' economy, remain very much with us" (Jackson, 2007, p. 211); that Canada is a "'hinterland-maquiladora type,' where staples exports are complimented by foreign-controlled manufacturing exports" (Ikeda, 2004, p. 278); and that all of this is still the result of a comprador capitalist class who "press for policies—-both domestic and foreign — that please the U.S. elite" (McQuaig, 2007, p. 59). ${ }^{17}$ From the perspective of Canada's dependency theorists, the country's experiences with globalization have been nothing but increasing dependence on the United States and further incorporation into the American empire.

Despite the dominance of dependency theory in Canadian political economy, the interpretation has been widely critiqued. Moore and Wells (1975), for instance, critiqued

17 This list comes from Klassen (2009). 
dependency approaches for neglecting the wider development of the world economy. Through a comparative analysis of advanced capitalist countries, they argued that Canada was no longer dependent, but becoming an imperialist power in its own right. Resnick (1982) made a similar argument, noting that by the 1980s the Canadian economy had matured. With Canadian ownership increasing as a share of the domestic economy, he argued that Canadian capital was no longer dependent, but "becoming a significant participant in the international capitalist economy" (p. 15). Other studies by Michael Kaufman (1985) and Jorge Niosi (1985) came to a similar conclusion: Canadian capitalists had regained the majority of assets in the domestic market and were rapidly expanding abroad. Furthermore, some historians began to dispute the claim that Canada's dependency resulted from the historical dominance of mercantile-financial capitalists over industrial capitalists. As they noted, more often than naught, these were the same people (Drummond, 1987; Macdonald, 1975; Richardson, 1982).

These empirical and historical critiques of dependency theory were complimented by a series of theoretical critiques from more orthodox Marxist scholars. David McNally (1981), for instance, argued that staples theory was a form of commodity fetishism that implicitly shifted the analytical focus away from the social relations of production and toward the exchange and circulation of commodities. Ray Schmidt (1981) similarly asserted that the NCPE relied on "a revision of bourgeois historiography with the addition of concepts adopted from dependency theory" (p. 87). He argued that this combination shifted the focus of analysis to the "behavioural characteristics of the dominant fraction of Canadian capital," thus limiting the "ability to formulate a class analysis" (p. 87). Leo 
Panitch (1981) critiqued the state theory of dependency theories, contending that the Canadian state was not simply a tool of domestic financial capitalists, but rather, had a more complex role that entailed maintaining the "social conditions for economic growth and the reproduction of classes in a way consistent with the dynamics of the capitalist economy" (p. 24). Finally, William Carroll $(1982,1985,1986)$ argued that dependency theorists had misjudged the relationship between industrial and financial capital. Through an analysis of corporate interlocks he argued that Canada was no longer dominated by domestic financiers whose interests ran counter to the development of industry, but rather, by an indigenous bloc of finance capital consisting of the directors of the banks, insurance companies, and large manufacturers. As such, Carroll (1985) argued that Canada could more accurately be described as a "middle-range imperialist power in an era of thoroughly internationalized monopoly capitalism" (p. 45).

Today there are an increasing number of scholars who take this latter position (e.g., Albo \& Klassen, 2013; Carroll, 2012; Burgess, 2000, 2002; Deneault \& Sacher, 2011; Gordon, 2010; Kellogg, 2005, 2009, 2015; Klassen, 2008, 2009, 2014). William Burgess (2002), for instance, writes that "the largest and presumably most powerful concentrations of capital remain in Canada hands," and therefore, that dependency theorists have "missed one of the most characteristic features of Canadian capitalism - the extent of indigenous monopoly" (p. 142). Paul Kellogg (2005) similarly finds it hard to reconcile the image of Canada the neocolony "with Canada the active participant in the G8 and the WTO" (p. 32). As he points out, a substantial majority of assets and revenues within Canada are owned and controlled by Canadian capitalists and that this represents "a long- 
term tendency, well entrenched now for more than 30 years" (p. 36). Jerome Klassen (2009) argues that in terms of economic structure and technological imports: "Canada still ranks as a secondary power" (p. 175). For all these authors, the central point of evidence is that Canada now exports more capital than it imports, giving it "the classic profile of an imperialist power" (Kellogg, 2005, p. 48). For Klassen (2014) and Carroll (2012) this makes Canada part of a collective imperialism of advanced capitalist states that manage the global economy and maintain the existing relationship between the core and the periphery. As Klassen (2014) puts it in the introduction to his recent book, Joining Empire: "the concept of empire, or imperialism, best explains Canada's role in the world economy and the nation-state system today" (p. 30).

This dichotomous perspective of Canada as either a dominated or dominating country has been problematized by other NCPE scholars (see, e.g., Draimin \& Swift, 1975; Ehrensaft \& Armstrong, 1981). Both Wallace Clement $(1975,1977)$ and Glen Williams $(1983,1988)$, for instance, hesitated to label Canada as being strictly part of the core or periphery. Despite being commonly lumped together with Naylor as part of the so-called 'Naylor-Clement thesis' by virtue of their shared appreciation for the mercantile-financial character of Canada's ruling class, Clement (1977) was clear to note that while "Canada sits firmly among the advantaged" (p. 130) it also had patterns of uneven development that tended to more closely resemble nations on the periphery, such as high foreign control of resources and a relatively underdeveloped manufacturing sector. Influenced by world-systems theory, the problem for Clement (1977) was not so much in the classification of Canada, which could go either way, but in using "the nation-state as the 
object of analysis" (Mertins-Kirkwood, 2014, p. 16). In his view, Canada was better understood as a 'go-between' nation since it played "a rather unique role as mediator of foreign-controlled capital, as holders of its own foreign investments, and as host to extensive foreign investments" (p. 24). Noting that "there are classes in all nations that benefit from the structure of dominance" (p. 22) Clement (1977) concluded that it was more accurate to treat Canada as a "subsystem of global capitalism divided along class lines" (MertinsKirkwood, 2014, p. 17) than as a self-contained actor responding to external forces (as in theories of imperialism and dependency).

This view was expanded upon by Williams (1983) who similarly hesitated to locate Canada strictly in the periphery or the core of the world economy. Also influenced by world-systems theory, Williams (1994) agreed that Canada was "never driven into the underdeveloped periphery" (p. 14) but that it was still inaccurate to call Canada an imperialist power by virtue of the political and economic dominance of the United States: whether in terms of trade, corporate ownership, or foreign investment, Canada was subservient to its continental neighbour. Through "an analysis of the historical weakness of the manufacturing sector in Canada" (Mertins-Kirkwood, 2014, p. 17), Williams (1988) challenged the perspective that Canada only relates to the global political economy through the struggle between national capitals. He concluded that while Canada was "firmly within the economically developed centre of the international political economy" (p. 13) that it could more accurately be described as "a zone within the American economy than a distinct national economy" (p. 15). 
Although they continue to be critiqued by those scholars taking the imperialist interpretation (e.g., Kellogg, 2009, 2015), the contributions of Clement and Williams provided much-needed nuance to the debates over Canada's 'location' in the global political economy. By reconciling the either-or views of this 'location,' they were better able to speak to the class character of Canadian society. While Canadian capital certainly has imperial ambitions, the country's subordinate classes tend to experience the effects of a dependent economy firsthand (Mertins-Kirkwood, 2014, p. 18). This need for nuance in Canadian political economy was championed later by Watkins (1989) who noted that while Canada's capitalist class may have retaken the majority of assets in the domestic market, that this does not necessarily make Canada, by definition, an imperialist power. As a variety of scholars point out, this shift can be just as easily explained as the result of changing patterns of American investment (e.g., Baragar \& Seccareccia, 2008; Marchak, 1985; Soederberg, 2000; Sweeny, 1997). Furthermore, as the historian Robert Sweeny (1997) notes, there was never the emergence of finance capital in Canada as suggested by the earlier theories of imperialism, a fact that problematizes the extent to which the concept can be applied to Canada and used to make claims about Canadian development (despite the fact that he does it himself):

Finance capital in Canada did not take on the same forms as its better known contemporaries in Europe and the United States. With the exception of their trust company subsidiaries, none of these banks controlled directly their associated companies in manufacturing, transportation, finance and utilities (p. 325). 
This point has been backed up by other scholars of Canadian banking, who note that in Canada: "bank ownership in other corporations was the exception rather than the rule" (Van Houten, 1991, p. 96; see also, Galbraith, 1970). The point being that the reality is far more complex than simply noting that over time Canadian finance capital has recaptured the domestic market. Indeed, as Laura Macdonald (1997) points out, this "typically Canadian preoccupation with 'placing' ourselves within a given hierarchy of world power" (p. 185) tends to downplay or even ignore, "the nature of power in the international economy and its changing shape" (p. 185). The main question, then, is not simply whether Canada is part of the periphery or core of the global political economy, as suggested by Kellogg (2009), but rather, whether the conceptual framework of imperialism and dependency can accurately capture the nature of our global epoch and the changing role of the Canadian nation-state?

The essence of this question was in fact brought up much earlier by Patricia Marchak (1985) in an article aptly titled, "Canadian Political Economy." Although she did not use the term globalization, she was clear to point out that the inherent mobility of capital makes it difficult to 'locate' Canada's relative position by virtue of the composition of Canadian capital alone. As she notes:

Capital is mobile, Canadian capital no less than any other. It will flow into Canadian industry if there are higher margins of profit to be gained there than in Hong Kong or Alabama. It will flow into industry if there is more to be gained there than in loans on the international markets. This is true today, and must surely have been true in times past (p. 683). 
Noting that this mobility has all but increased over time, Marchak (1985) points out that this means that some Canadian capital today is now "embedded in transnational corporations which have long since ceased to have national domiciles; some in multinational corporations still operating to the advantage of one of the world's regions more than others" (p. 683). The point being that the relative strength of Canadian capital tells us little about the 'position' or actions of the Canadian nation-state today, which are more likely an expression of the wider logic of capitalism as it plays itself out in specific historical and geographical conjunctures. ${ }^{18}$ Indeed, as I point out in the section below, qualitative shifts to banking and finance over the last quarter of the 20th century have made it impossible to identify the nationality of capital today, meaning that we can no longer make generalizations about the Canadian nation-state on that basis. Furthermore, as the rights of capital are increasingly moved to the transnational level via so-called free trade agreements, we must ask whether the Canadian nation-state continues to play the same role as it once did, since it must now defend the rights of foreign capitals within the domestic market. Let us move, then, toward a closer examination of some of these new developments and how they problematize the conceptual framework of Canadian theories of imperialism and dependency.

18 Marchak (1985) proves this with a simple example: "As the international portion, and capital originally tied to U.S. parent firms, moves elsewhere for cheaper operating costs or new resources, the balance under Canadian control naturally increases in proportion. As well, the sales of Canadian properties in extractive industries (where most of the change has occurred) have permitted Canadian companies to expand within Canada; they have not pushed American companies away, but have rather picked up the pieces. In forestry they have picked up pieces that include denuded lands and antiquated mills, facts not revealed in Statistics Canada data on ownership" (p. 683). 


\subsection{New Developments in the Global Political Economy}

Theories of imperialism and dependency have recently been challenged by a number of scholars who argue that globalization has involved a number of qualitative changes at both the national and transnational levels that problematize the empirical basis of the theory of imperialism (e.g., Hardt \& Negri, 2000, 2005, 2009; Harris, 2005, 2009, 2010, 2014; Liodakis, 2005, 2010, 2012; Robinson, 2001, 2003, 2004, 2005, 2007, 2008, 2012, 2014; Sklair, 1997, 2001; Sklair \& Robbins, 2002). Often referred to as the global capitalism school, these theorists all share the view that: (1) since the 1970s new information and computer technologies have revolutionized the global labour process; (2) that the rise of transnational capital in the form of the $\mathrm{TNC}$ has been matched by the emergence of a transnational capitalist class (TCC); (3) that there is an emerging transnational state apparatus (TNS) made up of supranational institutions, nation-states, and global political and economic fora that works to reproduce the conditions for transnational capital accumulation; and (4) that the general trajectory of globalization is the removal of all barriers to a single, global capitalist mode of production. To these theorists, globalization is therefore not something that occurs at various times and places, but an emerging novel epoch 
within the history of world capitalism. ${ }^{19}$ As such, the global capitalism school believes

that we must move beyond the theory of imperialism as a means of explaining the global

political economy and instead focus on "a theory of capitalist expansion — of the political

processes and the institutions through which such expansion takes place, the class rela-

tions and spatial dynamics it involves" (Robinson, 2007, p. 23). ${ }^{20}$

The global capitalism school has been ruthlessly criticized by a number of schol-

ars in a wide variety of publications and symposia. ${ }^{21}$ Their overemphasis on global phe-

19 Hardt and Negri (2000) provide a good summary of how the global capitalism school contrasts with those that we've discussed above: "Many contemporary theorists are reluctant to recognize the globalization of capitalist production and its world market as a fundamentally new situation and a significant historical shift. The theorists associated with the world-systems perspective, for example, argue that from its inception, capitalism has always functioned as a world economy, and therefore those who clamour about the novelty of its globalization today have only misunderstood its history. Certainly, it is important to emphasize both capitalism's continuous foundational relationship to (or at least a tendency toward) the world market and capitalism's expanding cycles of development; but proper attention to the $a b$ origine universal or universalizing dimensions of capitalist development should not blind us to the rupture or shift in contemporary capitalist production and global relations of power. We believe that this shift makes perfectly clear and possible today the capitalist project to bring together economic power and political power, to realize, in other words, a properly capitalist order. In constitutional terms, the processes of globalization are no longer merely a fact but also a source of juridical definitions that tends to project a single supranational figure of political power.

Other theorists are reluctant to recognize a major shift in global power relations because they see that the dominant capitalist nation-states have continued to exercise imperialist domination over the other nations and regions of the globe. From this perspective, the contemporary tendencies toward Empire would represent not a fundamentally new phenomenon but simply a perfecting of imperialism. Without underestimating these real and important lines of continuity, however, we think it is important to note that what used to be conflict or competition among several imperialist powers has in important respects been replaced by the idea of a single power that overdetermines them all, structures them in a unitary way, and treats them under one common notion of right that is decidedly postcolonial and postimperialist. This is really the point of departure for our study of Empire: a new notion of right, or rather, a new inscription of authority and a new design of the production of norms and legal instruments of coercion that guarantee contracts and resolve conflicts" (pp. 8-9).

20 It is necessary to mention, here, that there are other Marxist theories of the global political economy that move beyond the conceptual framework of imperialism and dependency-most notably, the neoGramscian school represented by Stephen Gill $(1990,1993)$ and Robert Cox $(1981,1987)$. While their work provides useful insights into the relationship between material social forces, institutions, and ideas, they tend to reproduce a nation-state-centric framework even as they attempt to move beyond it. When Cox (1987) refers to 'types of state,' for example, he is referring to different types of territorial states; when he refers to 'world orders' he is referring to specific periods of hegemony within the interstate system. My attempt here is to move beyond the confines of the state and to demonstrate different ways of organizing property relations over time (from a national organization to a global configuration). For that reason, I have left out a more in-depth analysis of these scholars.

21 For instance: Theory and Society (2001), 30(2); Science and Society (2001-02), 65(4); Critical Sociology (2012), 38(3); Historical Materialism (2007), 15; Cambridge Review of International Affairs (2006), 19(3). 
nomena and their use of arbitrary periodization schemas has often left them scrambling to explain exactly why globalization represents an epochal shift; this is especially the case since, as some of their critics accurately note, capital has always been at least partly global (Harvey, 2000; Tabb, 2009; Wood, 2002b, 2007). ${ }^{22}$ Furthermore, their research has often lacked the level of specificity needed to support their claims of an emerging TNS, leading many scholars to reject it on the basis that it "is not a state, transnational or otherwise," and thus, "an unnecessary theoretical construct" (Cammack, 2009, p. 89, 90). These issues are compounded by the global capitalism school's insistence that the TCC has directly instrumentalized the TNS, despite significant evidence that capitalists remain fairly national in their networks (e.g., Carroll, 2012; Carroll \& Klassen, 2011). As Carroll (2012) notes in a critique, the hegemony of transnational capital "has been grounded less in the agency of a dominant class fraction imposing its will and more in the enhanced structural power that capital has attained" (p. 367).

Despite these various issues, the global capitalism school raises a number of valid concerns about the extent to which the conceptual framework of imperialism and dependency is still able to capture the reality of our emerging global epoch. In this section, I want to focus on two changes associated with globalization that challenge this frame-

22 For example, Robinson's (2004) schema is split into four capitalist epochs, each denoted by a symbolic date: the first, running from 1492-1789 is the epoch of mercantilism and primitive accumulation; the second, running from 1789-1900 is the epoch of competitive or classical capitalism; the third, running from 1900-1970 is the epoch of corporate or monopoly capitalism; and the fourth running from 1970 to today is the epoch of globalization (pp. 4-5). In contrast, Liodakis (2005) distinguishes three epochs based on technology, the organization subsumption of labour and resources under capital, the concentration of capital, and the varying forms of state authority and regulation: 1492-1900, the epoch of laissez-faire capitalism; 1900-1970s, the epoch of monopoly capitalism; and 1970s onwards, the epoch of globalization (p. 342). While both schemas are helpful for demonstrating the various historical forms of capitalist accumulation and their attendant social forms, they both fail to get at what is explicitly national or global about them. In other words, they fail to make the connections between these forms of accumulation and their attendant geographic political and economic expressions. 
work: (1) the collapse of the Bretton Woods system of fixed exchange rates in the 1970s, the emergence of new rights for financial institutions in the $1980 \mathrm{~s}$, and the effect of those rights on the ambiguity of the nationality of capital today; and (2) the wider movement of the rights of capital and the authority over those rights to the transnational level. Doing so should make clear that some level of conceptual recoding is necessary to grasp the character and nature of our emerging global epoch.

This reinterpretation is especially necessary in the Canadian context since, as William Coleman and Tony Porter (2003) note, the strength of Canada's banking sector has long been the basis on which Canadian theories of imperialism and dependency have staked at least part of their claims:

Some scholars have argued that this strength signifies Canada's over-reliance on commerce relative to more productive manufacturing activities and should be seen as a weakness. In contrast, others see the prominence of Canadian banks in Canada and abroad as a sign of Canada's advanced industrial status. They argue that this prominence marks the type of central role played by finance capital in coordinating the economy and extracting revenues from abroad that is characteristic of the largest and most developed capitalist countries (p. 243).

Since the 1980s, however, Canada's financial sector has undergone significant changes that mirror a wider transformation of capitalism itself. As noted in the diverse literature on the global political economy of finance, this process began with the collapse of the Bretton Woods system in the early 1970s (e.g., Christophers, 2013; Eichengreen, 1996/2008; Germain, 1997, 2010; Helleiner, 1994; Henwood, 1998; Konings, 2011; La- 
pavitsas, 2013; Norfield, 2016; Porter, 2005; Sassen, 2012, 2014a; Strange, 1997, 2015;

Varoufakis, 2011). As the restrictions on cross-border financial flows weakened after the collapse of Bretton Woods, they gave way in the 1980s to the deregulation of finance; that is, the removal of longstanding legal barriers separating banks, insurance companies, trust companies, and investment firms. ${ }^{23}$ As a result, banks have been able to transform themselves into huge global financial institutions, making them one of the most dominant institutions within the global political economy "at the leading edge of financial globalization" (Porter, 2005, p. 34). Furthermore, the vast transnational capitals flows generated by these newly deregulated financial systems have not only contributed to new forms of transnational regulation and governance (e.g., Germain, 2010), but also to "onion-like layers of transnational ownership" (Robinson, 2014, p. 34) that ultimately blur the lines of corporate nationality.

These changes are significant given that Canadian theories of imperialism continue to back up their claims with evidence that Canadian TNCs are controlled domestically and that the national ownership network remains strong (e.g., Brownlee, 2005; Kellogg, 2005, 2009, 2015; Klassen, 2008, 2009; Klassen and Carroll, 2011). But none of these indicators tell us very much. They certainly do not tell us anything about the activi-

23 Germain (2010) provides a brief summary of financial deregulation: "this began innocuously enough during the second Nixon administration, but really gained steam in the early 1980s under President Ronald Reagan and his conservative British counterpart Margaret Thatcher, who was Prime Minister throughout the entire decade of the 1980s. Between them, they eliminated the last vestiges of American and British capital controls, liberalized their respective stock markets and lightened the regulatory burden for much of their respective financial systems. Indeed, along with Reagan and Thatcher, conservatives took power across much of the industrialized world during the 1980s, and worked to free up capital in the hopes that it would reinvigorate their economies (which had suffered for the better part of a decade under inflation or stagflation) and allow them to meet their growing debt obligations. The economic reasoning which informed these developments has come to be identified as 'neo-liberalism,' and the policy mix arising out of this reasoning was labelled in 1989 as the "Washington Consensus"' (p. 57). 
ties of corporations today, nor the wider network of transnational ownership relations involved. As Bichler and Nitzan (2012) note:

The location of a firm's listing says nothing about its operations and owners. Many firms whose shares are traded in the financial centres of the United States and Europe in fact operate elsewhere. And then there is the issue of ultimate ownership. Recall that currently nearly one third of all global assets are owned by foreigners (and perhaps more, given the opaqueness of international criminal ties and money laundering). This proportion is already large enough to make it difficult to determine the 'nationality of capital', and if it were to rise further the whole endeavour would become an exercise in futility (p. 60).

As such, making claims based on the assumption that the nationality of TNCs can be determined by domicile or ownership networks neglects the fact that all corporations, no matter where they reside, have to deal with the fundamental nature of capitalism. The logic of competition and self-expansion inherent to the capitalist mode of production compels capital towards transnational accumulation and global interests as it grows. John Porter (1965) pointed this out much earlier, noting in his characteristic style that it is as difficult to tell the borderline at which a corporate executive ceases to be an American and becomes a Canadian as it is to tell the borderline between being tipsy and being drunk ... It is doubtful that nationality is relevant to the logic of corporate behaviour (p. 273).

The point made by Klassen and Carroll (2011) that "Canadian TNCs are almost all controlled domestically" (p. 387) is thus relatively meaningless in our present context. As 
others have pointed out, recent changes to the global political economy mean that "the methods which once revealed the economic elite through corporate directorships may no longer serve that purpose" (Clement, 2006, p. 147; see also, Drummond, 1984; Harris, 2014).

A further question might be whether TNCs possess any nationality at all? Even a quick glance at Canada's largest firms underlines the confusion inherent in attempting to identify the nationality of capital today. Over $75 \%$ of the world's mining firms are incorporated in Canada, with a further $60 \%$ registered on the Toronto Stock Exchange (TSX) "even though their capital is not necessarily Canadian in origin" (Deneault \& Sacher, 2012, p. 16). Most of these firms do not even possess a single mining claim on Canadian soil, including the so-called Canadian firms. As economist Jordan Brennan (2013) notes, determining what makes a firm Canadian is complicated:

Take Barrick Gold (stock symbol: ABX) as an example. It is the largest gold corporation in the world (by proven reserves). Barrick has its head office in Toronto but has shares trading on the Toronto and New York Stock Exchanges. It has approximately 25,000 employees dispersed across five continents and more than half of its 2011 production and gold reserves were outside North America (these facts are taken from its website). And if that wasn't complex enough, its Founder and Chairman—Peter Munk—is a Canadian citizen while Barrick’s top five share-holders (in the Autumn of 2011) were large institutional investors located in Los Angeles, New York and Chicago. So is Barrick Gold a Canadian firm? (p. 31). 
Our case, the Royal Bank of Canada (RBC), provides another example. Today, RBC operates in 51 countries and has the vast majority of its 72 subsidiaries registered in known tax havens such as the Channels Islands (18) and the Caribbean (14). This trend continues for almost all of the largest Canadian firms. Magna, the world's largest automative supplier, for instance, has 127 subsidiaries in locations such as Delaware, Michigan, Luxembourg, Austria, and Belgium, despite being headquartered in Aurora, Ontario. George Weston Ltd. (Loblaws, Weston Foods) similarly has production facilities all over North America, subsidiaries in Ontario, Switzerland, Delaware, and Indiana, and distribution networks connected to Mexico and South Korea. Suncor has eight principal subsidiaries in Canada, three in the United States, and eight in other locations including the United Kingdom, the Netherlands, and Germany, which represent the interests for Suncor's operations in the North Sea, Libya, and Syria. Even Bell Canada Enterprises (BCE) had interests in up to 74 countries around the world by 1976 (Wilson, 2000). Put simply, all of Canada's largest firms have numerous foreign subsidiaries, links to transnational ownership groups, and listings on foreign exchanges. By almost any metric they are TNCs. Even the Canadian government (2016) admits that since the North American Free Trade Agreement (NAFTA) was signed: "Canadian, American, and Mexican companies do more than sell things to each other-now, our companies increasingly make things together" (para. 8). Are we to assume that in this context Canadian TNCs somehow represent independent Canadian interests because most of their management group is Canadian and they are listed on Canadian stock exchanges? And how might we even begin to disentangle their financial operations from their productive and commercial dealings? 
What do Canadian theorists of imperialism and dependency even mean when they refer to Canadian capital?

The historian Jerry Harris (2010) asks similar questions in respect to the United States. He finds that "transnational auto companies are as much a part of the American economy as GM and Chrysler" (p. 396). In fact, as part of some of the cuts attached to the American government's bail-out of auto TNCs following the 2008 financial crisis, the U.S. operations of Toyota and Honda will match those of GM and Chrysler. Thus, the U.S. footprint and identity of GM and Chrysler will be significantly reduced; their U.S. operations are becoming simply one entity among many in their network of global accumulation. The so-called effort to save the 'American auto industry' has furthered its transnationalization (p. 401).

This reality forces Harris (2010) to ask — as we all should — what exactly "is meant by a U.S. auto industry in an era of globalization?" (p. 395) None of the various criteria that might be attached to the marker 'United States,' such as focusing on national over global interests, or having a majority of their sales, employment, or assets located in that country, applies to any of the transnational auto firms, including those typically thought to be American.

Looking at state-owned corporations and financial institutions, Harris (2009) finds similar results. As opposed to turning inward for the purposes of building up national or regional economies, state-owned firms have invested massively into transnational circuits: "overall an estimated $\$ 67 \mathrm{bn}$ in state funds have been invested in banks, securities houses and asset management firms" (p. 8). As former CEO of Goldman Sachs, Richard 
Gnodde (2007), notes, state-owned firms are "in no way incompatible with the process of globalization” (p. 11). Bichler and Nitzan (2012) provide another example:

In 1987, Kuwait Investment Office (KIO) took advantage of the privatization of British Petroleum to buy $22 \%$ of the company's outstanding shares. At the time, the neoliberal Thatcher government was so horrified by this attack on its national 'crown jewel' that it forced KIO to reduce its stake to a more acceptable $9.9 \%$. By contrast, when in 2008 Sheikh Mansoor of Abu Dhabi bought 16\% of Barclays Bank — and then sold it less than a year later for a 70\% profit—nobody even blinked. The difference? Capital has become totally vendible, within and across borders. There are no crown jewels any more. With the exception of 'nationalsecurity' companies and other such oddities, every asset is now fair game (p. 55).

To drive the point home, we need only quote Lou Jiwei, the former head of the China Investment Corporation (and now Minister of Finance), who states: "in the future, there will be no limits for us to invest all over the world" (McGregor, 2007, p. 9). ${ }^{24}$ Even business scholars agree that corporate nationality "is at best a convenient fiction" (Monks and Minow, 2011, p. 418).

Former IBM president, CEO, and Chairman, Samuel J. Palmisano (2006) has similarly argued that most people "mistakenly project into the future a picture of corporations that is unchanged from that of today or even yesterday" (para. 3). ${ }^{25}$ He cites the example of the MNC, which was an earlier hybrid built to avoid trade barriers by localizing

\footnotetext{
24 This is from Harris (2009).

25 This is from Robinson (2007).
} 
production. With the ongoing removal of those barriers, however, he argues that the emerging globally integrated enterprise or TNC "is a company that fashions its strategy, its management, and its operations in pursuit of a new goal: the integration of production and value delivery worldwide" (para. 9). As he concludes: "State borders define less and less the boundaries of corporate thinking or practice" (para. 9). Other executives, such as Douglas Daft and Niall Fitzgerald (2004), write that "most large companies can no longer be characterized as 'U.S.' or 'European' companies but rather as 'transatlantic companies"” (p. 13).26 And the former CEO of Lenovo, William J. Amelio (2007), writes that "in today's world, assessing companies by their nation of origin misses the point" (para. 12). ${ }^{27}$ This is all besides, of course, the mass amount of scholarship highlighting the rise of a new global ruling class (Burbach \& Robinson, 1999; Harris, 2005, 2014; Liodakis, 2005, 2010, 2012; Robinson \& Harris, 2000; Robinson, 2004, 2014; Sklair, 1997, 2001, 2002). Prior to taking her post as Canada's Minister of Trade (and now, Minister of Finance), Chrystia Freeland (2012) referred to this new ruling class as 'the plutocrats.'

The reliance on the significance of the national as is done when globalization scholars choose the label TNC over MNCs, represents an attempt to sidestep the issue of transnational integration in the first place. As Robinson (2004) notes: "the ability of TNCs to plan, organize, coordinate and control activities across countries makes them central agents of globalization and transnational processes" (p. 55). Put simply, TNCs "are the institutional form in which global capital accumulation is organized, the embod-

\footnotetext{
26 This is from Harris (2005).

27 This is from Robinson (2014).
} 
iment of transnational capital" (p. 55). Despite attempts by some to downplay this reality, it is supported by studies from the IMF, OECD, and the World Bank, among others. A study from the United Nations Conference on Trade and Development (UNCTAD) (2007), for instance, highlights that by 2007 alone there were already "an estimated 77,000 TNCs in the world, with more than 770,000 foreign affiliates" (p. 3). A more recent study by the same organization shows that from 1973 to 2011 world inflows of foreign direct investment (FDI) increased from $\$ 20,646$ to $\$ 1,197,824$ expressed in U.S. dollars in millions; outward flows increased from $\$ 14,151$ to $\$ 1,694,396$ (UNCTAD, 2012). Other research by a group of systems theorists at the Swiss Federal Institute of Technology demonstrates that there are only 1318 core TNCs with interlocking directorships making up $80 \%$ of global operating revenues. In their attempt to untangle this web, they found that "nearly $4 / 10$ of the control over the economic value of TNCs in the world is held, via a complicated web of ownership relations, by a group of 147 TNCs in the core, which has almost full control over itself" (Vitali et al., 2011, p. 6). Made up of major global financial institutions such as Goldman Sachs, JP Morgan Chase, and Barclays Bank, among others, this super-entity of TNCs reveals not only the significance of financial capital today, but the extent to which capital in general is concentrated and centralized at the transnational level.

These are but a few examples. But they highlight the fact that the significance of corporate nationality today remains ambiguous at best. All the largest corporations in almost every country have transnational interests. Even the work of business scholar Geoffrey G. Jones (2006), who is often cited by scholars to back up the significance of corpo- 
rate nationality, agrees that "equity ownership of large corporations is now widely dispersed among countries" (p. 21). What are we to make, then, of claims that Canada is an imperialist power because Canada's TNCs are owned and controlled domestically? While it is certainly true that Canada now exports more capital than it imports, and that foreign ownership of Canadian assets and revenues remains low, there is little to no discussion of the fact that since 1996 direct investment in both directions has tripled. Or that the main sector for investment both abroad and in Canada is not in manufacturing, but in finance, insurance, and management services, with a significant (but unknown) portion of these funds flowing through known tax havens. ${ }^{28}$

By themselves, these changes raise the question of whether the conceptual framework of imperialism is able to capture the conditions of our present reality, including the status of Canada and its 'position' in the global political economy. Since the social relations of global capitalism cut across our conceptual boundaries - "the terms and categories we use to think about the economy, the polity, the diversity of nation-states and ideologies from communism to capitalism" (Sassen, 2014b, p. 215) —I think it behooves us to start asking, as Sassen (2014b) does, whether "these geographical markers of an earlier era [are] still helpful for understanding the character of our epoch?” (p. 215).

28 In 2009, foreign ownership of Canadian assets and revenues was $19.7 \%$ and $28.9 \%$, respectively (Statistics Canada, 2011). Furthermore: "In 2012, 52.9\% of total Canadian direct investment abroad was in the finance, insurance, and management industries, followed by the mining and oil and gas extraction sector with $18.8 \%$. Meanwhile, the share of investment in manufacturing fell below $10 \%$ for the first time, continuing a decline which has seen that sector's share of Canadian investment abroad decline from a peak of $31.9 \%$ in 2000. The finance, insurance and management industries also accounted for a significant share of foreign direct investment in Canada with 32.6\% of total investment in 2012. The manufacturing sector remained a significant destination of foreign direct investment in 2012 with a $28.7 \%$ share, while the mining and oil and gas extraction industry accounted for a further 19\%" (Statistics Canada, 2013). 
This is especially the case when we consider how the legal framework on which global, regional, and bilateral free trade agreements dismantle "barriers to the movement of goods, services, and capital" (Clarkson \& Wood, 2010, p. 70; see also, Clarkson, 2001, 2004, 2008; McBride, 2005, 2011). In Canada, as elsewhere, these so-called free trade agreements not only provide foreign firms with new domestic rights, but also work to limit national laws and regulations; grant new rights and means of adjudication to TNCs; create new denationalized means of enforcement; and shift power away from subnational governments toward national governments. Their main function, therefore, is "to liberate transnational capital from the limitations of majoritarian politics" (Clarkson \& Wood, 2010, p. 69).

They do this by enabling TNCs to sue both federal and provincial governments if their ability to accumulate capital is constrained. These cases are not heard in national courts but in secret, non-democratic tribunals. ${ }^{29}$ As Brennan (2013) notes, these tribunals are essentially exclusive courts for capitalists which enable "investors and corporations to constrain government policy and regulation by submitting damage claims for alleged 'interference' with their 'rights'” (p. 24). Joe Oliver, the former Canadian Minister of Finance, is quoted as saying that investor-state dispute settlements (ISDS) could be used to overturn banking regulations passed in the wake of the 2008 financial crisis (Sirota, 2015). Few Canadians know, for instance, that the federal government has already paid

29 George Monbiot (2013) provides a description: “These companies (along with hundreds of others) are using the investor-state dispute rules embedded in trade treaties signed by the countries they are suing. The rules are enforced by panels which have none of the safeguards we expect in our own courts. The hearings are held in secret. The judges are corporate lawyers, many of whom work for companies of the kind whose cases they hear. Citizens and communities affected by their decisions have no legal standing. There is no right of appeal on the merits of the case. Yet they can overthrow the sovereignty of parliaments and the rulings of supreme courts" (para. 7). 
out NAFTA damages totalling over $\$ 172$ million (Sinclair, 2015). The United Nations (2013) also reports that these types of settlements are on the rise with the total number increasing to 514 by the end of 2012 .

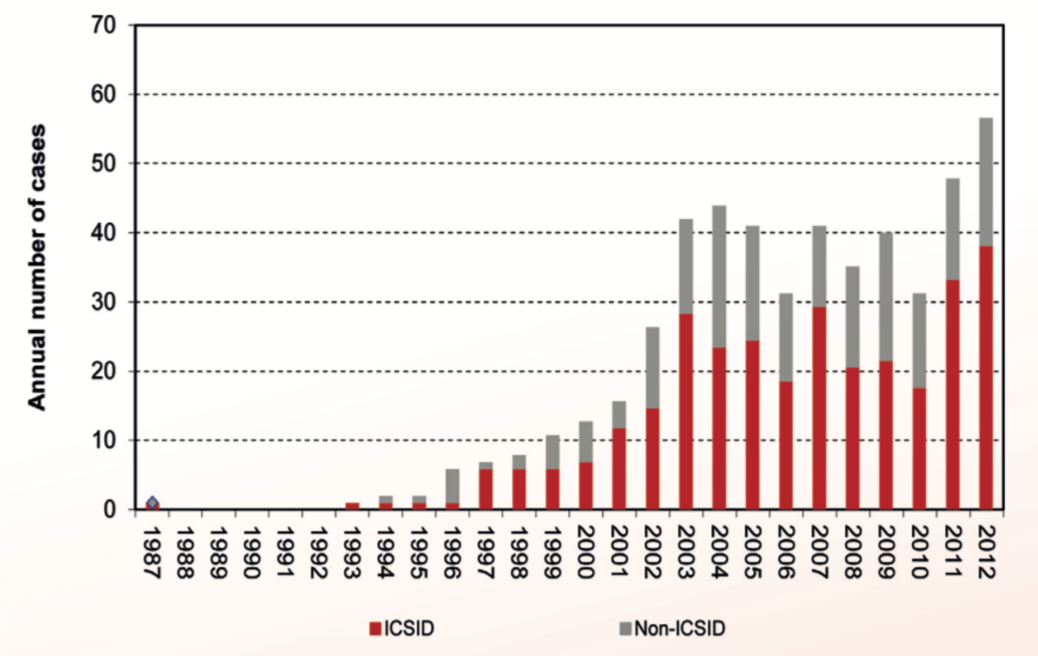

Figure 1. Known Investor-State Dispute Settlement Cases. ICSID refers to cases registered with the International Centre for Settlement Investment Disputes. Reprinted from UNCTAD: Recent Developments in Investor-Dispute Settlement, May 2013. Copyright 2013 by UNCTAD. Reprinted with permission.

As such, I believe that it is a mistake to treat these agreements-which some refer to as a 'supra-constitution' (Clarkson \& Wood, 2010) — as merely the continuation of capitalist imperialism. It is worthwhile to recall that the theory of imperialism originally referred to the domination of a non-capitalist periphery by a capitalist core. However, these agreements also constrain the largest imperial powers as well. In an op-ed to the Washington Post, U.S. senator Elizabeth Warren provides an example:

If a Vietnamese company with U.S. operations wanted to challenge an increase in the U.S. minimum wage, it could use ISDS. But if an American labour union believed Vietnam was allowing Vietnamese companies to pay slave wages in 
violation of trade commitments, the union would have to make its case in the

Vietnamese courts (Sirota, 2015, para. 5).

In providing foreign firms with new domestic rights to challenge national governments, these so-called free trade agreements restructure national property relations to benefit capital in general. In doing so, they transform the very conditions that made capitalist imperialism possible in the first place: a strong nation-state that acts on behalf of its national capital. Indeed, as McBride (2005) notes, many of the state capacities that were once used to develop the Canadian economy are no longer legally possible, and "others are increasingly under threat from these types of international economic agreements as they reach further and further into the realm of domestic policy" (p. 186). By marking "as negative a broad range of regulations that constrain the search for profits," these so-called free trade agreements can even push "national states to go against the interest of national firms" (Sassen, 2013, p. 36). Can such novel political and economic development be captured under the conceptual framework of imperialism and dependency? And, if not, how might we attempt to understand what is happening?

\subsection{Conclusion}

In the debate so far, attempts to determine the character of our age have rested on the status of capital. The basic formula goes something like this: if capital can be proven to be national, then contemporary political and economic events can be explained by the theory of imperialism; if capital can be proven to be transnational, then it becomes necessary to rethink the relationship between capital and the state; in other words, the bound- 
aries and meaning of political space. The result has simply been an ongoing back and forth, with each side attempting to demonstrate that production, accumulation, and class are more or less national, more or less global. However, neither approach gets us very far in overcoming the basic antagonism between continuity or change inherent to the debate over globalization.

Part of the problem is that capital is not a thing, but rather, "a definite social relation of production pertaining to a particular historical social formation" (Marx, 1991a/ 1894, p. 953). As such, simply pointing to transnational or national processes does not, in itself, explain why or how the 'shape' and structure of the global political economy is changing. This sort of all-or-nothing approach to globalization does little to help us understand the novel aspects of globalization as an epoch, especially since many globalizing processes tend to be located within national domains. Theories of imperialism and dependency are certainly limited by the mere fact of capital's ambiguity. They seem to reflect Marx's (1986) comment that "it is generally the fate of completely new historical creations to be mistaken for the counterparts of older, and even defunct forms of social life, to which they may bear a certain likeness" (p. 289). Labelling capital as global and then drawing numerous conclusions from that can be just as foolhardy, however. Doing so forces us to explain the emergent properties of our global epoch as if they were already formed, and thus, structurally dominant. That said, if we accept the point that qualitative changes to global finance have made it almost impossible to identify the nationality of capital, then theories of imperialism and dependency lose much of their analytical value. 
This is significant when we consider Canada. With the exception of domestic ownership and control, it is not clear that we can even label the largest, most dominant, Canadian firms as Canadian. Delimiting Canada as either dependent or imperialist in this context thus neglects the fact that the very configuration of the global political economy that made imperialism possible in the first place has changed. This is partially an issue of methodology. While Canadian political economy speaks to the issue of historical change, much of the methodology utilized for such purposes has been historically static, focusing on some basic metric such as board interlocks or the ownership of domestic assets that is then related back to Marx's theory of historical change. What we need, however, is a wider conceptual framework that can allow us to move from the macro-sociological level of the global political economy back down toward the specific activities of Canadian firms. Doing so will allow us to comprehend just how much the terrain of action on which capitalist activity unfolds has changed over time. I take on this challenge in the next chapter. 


\section{Property and Periodization: Thinking of Historical Property Regimes as Assemblages of Territory, Authority, Rights}

All property relations in the past have continually been subject to historical change consequent upon the change in historical conditions.

—Karl Marx \& Friedrich Engels, 1848.

Political economy is the study of power derived from or contingent on a system of property rights; the historical development of power relationships; and the cultural and social embodiments of them.

—Patricia Marchak, Sociologist, 1985.

\subsection{Introduction}

In the last chapter, I highlighted a number of qualitative changes to the global political economy that challenge the conceptual framework of imperialism as a means of understanding and explaining globalization, and thus, Canada's experiences with it. I concluded by stating that we need a new framework that will allow us to move from the macro-sociological level of the global political economy back down toward the specific activities of Canadian firms. I claimed that this would allow us to have a much better understanding of just how much the terrain of action on which capitalist activity unfolds has changed over time so as to better register the implications.

In this chapter, I take on this challenge and attempt to provide a new conceptual framework for thinking about globalization as an emerging property regime. To do so, I want to bring our focus back to banking. As I pointed out in the last chapter, Canadian theories of imperialism and dependency base at least part of their claims on the strength 
of Canada's chartered banks. For dependency theorists, this strength signifies Canada's over-reliance on commerce relative to production and is indicative of the country's weakness; for the imperialist theorists, this strength is reflective of the country's advanced industrial status by virtue of the "central role played by finance capital in coordinating the economy and extracting revenues from abroad that is characteristic of the largest and most developed capitalist countries" (Coleman \& Porter, 2003, p. 243). As I highlight below, however, these theories are all based on Marx's (1867/1991b) overly schematic analysis of the emergence of capitalism that treats banking as secondary to industrial production. As a result, there has been an overall neglect of the actual role played banks and other financial institutions in changing the property relations that have hampered their growth and expansion over time — especially in places like Canada, where they have long been the strongest social actors. In this chapter, I argue that we need to look more closely at how banking has changed over time, given the extent to which the globalization of banking and finance is often taken as the "quintessential case or driving force of globalization" (Porter, 2005, p. 13).

To take a closer look at how banking has changed, I argue through an analysis of Marx's writings on property that a clearer case can be made for the transnational state on the basis of the movement of the rights of capital to the transnational level. To make the extent of this transformation clearer, I suggest that we blend Marx's insights into property with the analytical framework of Saskia Sassen (2006) to conceptualize historical property regimes as assemblages of territory, authority, and rights (TAR). I claim that by disaggregating the national and the global into these components parts, we are able to avoid 
taking the position that just because the nation-state is still here that it acts in the same way that it always has. The purpose of the chapter is thus to setup a framework for analyzing the history of the Royal Bank of Canada so that we can better register the qualitative changes that are beginning to characterize our emerging global epoch.

The chapter proceeds as follows. First, I examine the neglect of banking in Marx's discussion of the transition to capitalism and argue that the fractional view of capital (the view that capital is made up of different fractions that represent the different circuits of the accumulation process) neglects the actual and complex lived history by which capitalism came into existence and the role that merchants, bankers, and financiers played in transforming feudal property relations. Next, I explore how thinking about historical property regimes as assemblages of territory, authority, and rights might better allow us to grasp epochal-level change without having to posit that the new order automatically distinguishes the old. I conclude by suggesting we use this framework to examine the historical trajectory of Canada's most dominant bank, the Royal Bank of Canada. In doing so, we should be able to better highlight how the growth of capital over the 20th century is resulting in the emergence of a new organizing dynamic that is drawing elements of TAR away from the nation-state and toward the transnational level, with potentially dire effects.

\subsection{The Neglect of Banking in Critical Political Economy}

There is a significant weakness in Marx's analysis of the transition to capitalism that has been carried through more recent studies of the world economy and Canadian 
theories of imperialism and dependency. Although Marx (1867/1991b) was interested in the unique nature of the social relations that constituted the capitalist mode of production, he was particularly interested in industrial capital, the form of wealth involved in the production process (e.g., factories, mines, railroads). Consequently he had much less to say about those other forms of capital involved in circulation and exchange such as commercial or financial capital (both emerge from merchant capital). This selective focus reflects one of the main precepts of the historical materialist method; that is, that history moves forward through the development of the productive forces and that industrial capitalists (along with their counterpart, the industrial proletariat) are the agents of this type of economic change. Noting that "commercial and interest-bearing forms of capital are older than industrial capital" (p. 468), Marx (1969) pointed out that they did not necessarily lead to the development of capitalism in and of themselves. For instance, in his description of the role of merchant's capital, Marx (1867/1991b) notes that it remains stuck in the sphere of circulation and thus does not have a significant effect on the productive forces of society:

It can be understood, therefore, why, in our analysis of the primary form of capital, the form in which it determines the economic organization of modern society, we have entirely left out of consideration its well-known and so to speak antediluvian forms, the merchants' capital and usurers' capital.

The form $\mathrm{M}-\mathrm{C}-\mathrm{M}^{\prime}$, buying in order to sell dearer, is at its purest in genuine merchants' capital. But the whole of this movement takes place within the sphere of circulation. Since, however, it is impossible, by circulation alone, to explain 
this transformation of money into capital, and the formation of surplus-value, merchants' capital appears to be an impossibility, as long as equivalents are exchanged; therefore, that it can only be derived from the twofold advantage gained, over both the selling and buying producers, by the merchant who parasitically inserts himself between them. It is in this sense that Franklin says 'war is robbery commerce is cheating.' If the valourization of merchants' capital is not to be explained merely by frauds practised on the producers of commodities, a long series of intermediate steps would be necessary, which are as yet entirely absent, since here our only assumption is the circulation of commodities and its simple elements (pp. 266-267).

According to Marx's labour theory of value, only the expenditure of living labour in the production process of a commodity can create new value; as such, only industrial capital includes a process that creates new wealth, rather than just siphoning it off from other sectors of society. Since commercial and financial capital play no significant role in the production process according to Marx, they are relatively unimportant for his schematic analysis of a pure capitalist system as it exists in Capital.

The neglect of merchant capital in the schematics of Capital is contradicted by Marx's more accurate, albeit, sometimes confusing, historical writings on the 'so-called primitive accumulation.' For Marx (1894/1991a) the development of merchant capital (that is, capital involved in circulation, either commercial or financial) was a historical precondition for the development of the capitalist mode of production because it enabled the concentration of monetary wealth and production for trade, which subsequently trans- 
formed "products more and more into commodities" (p. 444). However, since this form of capital existed in a variety of older social formations, Marx (1894/1991a) was reluctant to give it a revolutionary role in the emergence of capitalism. As he notes, merchant capital, "taken by itself, is insufficient to explain the transition from one mode of production to the other" (p. 444). That statement seems contradictory when we place it beside Marx's (1867/1991b) analysis of the so-called primitive accumulation, which was the process that first gave money the magical power of capital, the ability to self-expand. Arguing against the classical political economists who portrayed the prehistory of capital in terms of thrift and hard work, Marx (1867/1991b) argued instead that capital emerged through state power via colonialism and the development of the credit system (pp. 915-919). Through the creation of the national debt (what Marx referred to as the 'alienation by sale' of the state) and the tax system, Marx (1867/1991b) argued that the transition from feudalism to capitalism was sped up "as in a hothouse" (p. 915). Indeed, as Marx points out, it was the emergence of the national debt that "marked the capitalist era with its stamp" (p. 919).

As the economist Anthony Brewer (1980/2002) notes, however, the exact role of these factors in the transition is not very clear (p. 41). All Marx (1867/1991b) offers on the subject is a brief exegesis on the role of the public debt, which allows, with "the stroke of an enchanter's wand" (p. 919), the creation of public bonds, which make sure that creditors are never exposed "to the troubles and risks inseparable from [capital's] employment in industry or even usury" (p. 919). The logical presumption is that the riches captured from the colonies by looting, enslavement, and murder flowed back to Eu- 
rope to be transformed into capital via "a turnover in the actual personnel of the landowning class, with nouveau riches buying out declining and indebted feudal magnates" (Brewer, 1980/2002, p. 41). In any case, Marx (1867/1991b) was not so much interested in the process, but rather, the result: "the national debt has given rise to jointstock companies, to dealings in negotiable effects of all kinds, and to speculation: in a word, it has given rise to stock-exchange gambling and the modern bankocracy" (p. 919). Despite being decorated with national titles, the great banks were, in his view, simply groups of private speculators: "the agents and beneficiaries of economic violence" (Dodd, 2014, p. 60). This is why Marx (1867/1991b) remarked that capital comes into the world "dripping from head to toe, from every pore, with blood and dirt" (p. 926). It is also why banks figure so prominently within the classical theories of imperialism. Through the credit system, Marx (1894/1991a) saw the emergence of "a new financial aristocracy, a new kind of parasite in the guise of company promoters, speculators and merely nominal directors" (p. 569). The supposed dominance of banks over industry through the credit system is what eventually forms the basis of later theories of imperialism via the concept of finance capital.

This parasitic view of banking has since led to a tendency to view the emergence of capitalism as a fraction struggle between an emerging industrial capitalist class and those older social groups tied to interest-bearing and commercial capital, forms which are "found in the most diverse socio-economic formations" (Marx, 1867/1991b, p. 728). As a result, banking has often been treated as a subordinate form of accumulation that operates solely "in accordance with a specific logic determined by the dominant social-property 
relations and the prevailing conditions of social reproduction" (Wood, 2007, pp. 162163). While this is true to a certain extent given the dependent nature of financial capital, it neglects the reality that all social actors have the agency to influence the property relations of their respective social formations; that is, the ability to change the rules relating to what it is they do to sustain their livelihood. Treating production as primary and circulation secondary thus neglects the role of merchants and financiers in the transformation of feudal property relations and the transition to the capitalist mode of production (see, e.g., Ingham, 1999). As anthropologist Eric Wolf (1982) notes:

By dint of its very success, mercantile wealth began to multiply the channels of commodity exchange, rendering tribute takers increasingly dependent upon it. It generated ever larger amounts of money-begetting money and invested that wealth so as to increase the flow of commodities to the market. In the process it drew producers in different parts of the world into a common web of exchanges, adjusting existing relations of production to embrace commodity exchange, or subsidizing coercive arrangements for the production of commodities (p. 86). Indeed, if one is to look back on European history from the 16th century onwards, merchants (and the banks that resulted from their accumulation activities) played a key role in the establishment of a world trading system, actively facilitating the race for the colonies by the European powers, and often playing a quasi-military role in suppressing resistance from local populations (e.g., the Hudson's Bay Company). In their analysis of the English merchant class, for instance, Robert Brenner (2003) and Bruce Carruthers (1996) have both demonstrated just how much of England's early modern politics was 
influenced by the demands of the commercial sector. Similarly, Jairus Banaji (2007) has argued that the great mercantile companies of the 17 th and 18 th centuries were clearly "involved in production in ways that contradict the concept of merchant capital as a mere mediation between extremes" (p. 65). Since "it was merchant capitalism which innovated the unlimited partnership and the whole spectrum of forms of association that flowed from it" (p. 55), Banaji argues that it is "unreal to suppose that the self-expansion of commercial capital was simply grounded in some simplistic formula like 'buying cheap and selling dear"' (p. 65). This point is backed up by Brenner (2003) and Carruthers (1996) who, in demonstrating that the English merchants also wielded great political power, prove that merchant capital played a central role in the creation of modern capitalism and the consolidation of the national state (see also, Brewer, 1980/2002).

Although Marx (1894/1991a) was weary to give merchant capital a revolutionary role in the development of capitalism, even he did not completely discount it from being able to; he simply gave the caveat that it would depend "entirely on the historical level of development and the conditions this provides" (p. 729). In simply pointing to the primacy of industrial capital or the labour theory of value, many theorists have thus ended up neglecting the actual lived history in which capitalism came into being and the relevant property relations that had to be transformed in the process. This is especially important in Canada, where it was an early landed class of 'gentlemanly capitalists' (discussed in the next chapter) who, in concert with the colonial administration, first utilized the corporate form to implement government functions without parliamentary accountability, provide the money supply of the colonies, constrain democratic pressures in the urban cen- 
tres, and administer the construction of Canada's early transportation infrastructure (e.g., Schrauwers, 2008, 2010). While dependency theories have been correct to stress the mercantile-financial character of this early ruling class, their conclusions have tended to rely almost exclusively on the idea that Canada's dependent status follows from the fact that this class was involved in accumulation activities relating to circulation and not production (e.g., Clement, 1975, 1977; Naylor, 1972, 1975/1997; Teeple, 1972). As some Canadian historians have pointed out, however, this view is not entirely accurate (Macdonald, 1975; Richardson, 1982). ${ }^{30}$ Many merchants were clearly involved in manufacturing, and the many difficulties relating to Canada's early industrial ventures seem to have had more to do with issues relating to the small size of the population and lack of infrastructure, rather than the specifically mercantile orientation of Canada's early ruling class (e.g., Pentland, 1981). Similarly, as Neil Quigley (1986) notes in the case of banking (a significant part of the debate), there is no evidence before 1914 that Canadian banks "actively 'sought out' American investors; or that bankers clearly identified their own interests, and those of the financial institutions for which they worked, as complimentary to those of American industrialists" (pp. 52-53).

These historical issues with Canadian dependency theories are compounded by more theoretical ones, relating to an overly schematic view of the fractional nature of the

30 As L.R. Macdonald (1975) notes, evidence from England and the United States "makes it impossible to argue that, as a general rule, merchant capital has historically discouraged the growth of industry. Just the opposite. Adherents of the theory are forced, then, into the unenviable position of asserting that Canadian merchants were different than merchants elsewhere. Unenviable because very little Canadian evidence has been collected on the matter, and what there is suggests they were not. Moreover, even if anything at all can be proven, it will not be characteristic of 'mercantile capital' at all, but merely a predisposition of Canadian merchants, a much less exciting prospect. There are various indications that in Canada, as elsewhere, merchants were the strongest supporters of, and got deeply involved in, the growth of manufacturing" (pp. 273-274). 
capitalist class that rests on the primacy of production. In reality, the various processes of production and exchange are not separate; they are both integral parts of production as a social process. ${ }^{31}$ As Brewer (1980/2002) notes: "capitalist production as a whole includes many separate production processes and the processes of exchange that link them" ( $p$. 29). Since interest-bearing capital is essentially the reallocated spare money capital of the capitalist class, it "does not constitute the revenue foundation of a separate social groupof the 'monied' capitalists" (Lapavitsas, 2013, p. 118). This is not to deny the significance of the mercantile-financial character of Canada's early ruling class, but rather, to be wary of making claims that apply to the entirety of Canadian history on that basis.

Similar problems are found in Canadian theories of imperialism, which continue to rely heavily on the historically flawed concept of finance capital. As noted in the last chapter, the concept was created by Hilferding (1910/1981) based on a close analysis of German banking that does not apply to the Canadian case. In Canada, banks have not been involved in the ownership of industrial firms and are actually prohibited from doing so in the Bank Act (Galbraith, 1970). While scholars taking the imperialist perspective are accurate in stating that Canadian corporations have largely retaken ownership of the productive sector from American interests (e.g., Carroll, 1982; Klassen, 2009; Kellogg, 2005; Niosi, 1985), it does not automatically follow that this makes Canada a secondary imperialist power. As Watkins (1989) notes, the imperialist argument was initially con-

31 As Robinson (2014) notes, this is because: “The capitalists' class power is asserted over corporations and states - as well as over the popular classes via these institutions - through financial mechanisms. The generalization of exchange value that is a defining characteristic of capitalism presupposes that money embodies the whole set of capitalist relations, including social power relations and the exercise of social power through institutions, especially through the state. Under capitalism, production is always for profit, and the realization of profit is always through exchange for money. Production and money are therefore in unity unless that unity is broken by crisis" (p. 140). 
structed on the basis of a static, non-historical analysis of the interlocking directorates of the largest corporations in Canada; in more recent studies, this methodology continues to be used (e.g., Carroll, 2004; Carroll \& Klassen, 2010, 2011). In conflating financial and industrial capital together into the amorphous form of finance capital, however, these theories tend to downplay some of the more important aspect of Canada's actual historical development, such as the mercantile-financial character of Canada's early ruling class, and the reason why banks have long been the most dominant indigenous corporations. This is most clear in their classification of all infrastructure as industrial (e.g., Carroll, 1986) without clarifying the reality that almost all "manufacturing in Canada grew in relation to the development of external trade - that is, in tune with the interests of the merchant ruling class (Teeple, 1972, p. 61). While the dependency theorists may have relied too heavily on the supposed nature of that class in making claims about Canadian development, to ignore its mercantile-financial character completely is to ignore a significant historical reality.

The point being that making claims based off the strength of different fractions of capital (as is done in the Canadian debate) neglects the basic reality that "all big capitalists tend to become money-capitalists" (Norfield, 2016, p. 55) and that "finance is not a parasitical entity but an integral element of the capitalist economy" (Lapavitsas, 2013, p. 122). Indeed, as Doug Henwood (1998) notes, within capitalism: “ownership is represented through monetary claims, and the exchange of those claims in the financial markets amounts to the social construction of ownership" (p. 11). The development of capitalism, whether in Canada or elsewhere, was therefore not the result of a fractional battle 
between the different embodied representatives of capital's circuitry, but a much more complex transformation of land, labour, and money into commodities (see, e.g., Myers, 1914/1972; Polanyi, 1944/2002). ${ }^{32}$ As Brenner (2003) notes in the English case, the development of capitalism was not in contradiction to the landed class (as is often suggested), but rather, something that "took place within the shell of landed property and thus ... to the benefit of the landed aristocracy" (p. 649). As such, we should avoid drawing a straight line from the mercantile-financial character of Canada's early ruling class to explain Canadian development, and instead look at the actual means by which the chartered banks - Canada's most dominant corporate sector- have been able to transform those property relations that have constrained their accumulation activities over time. In other words, rather than taking for granted the institutions of capitalist banking, we should actually examine how they have been arranged over time. Doing so will allow us to see how much the earlier national epoch of capitalism differs from our own.

\subsection{Historical Property Regimes as Assemblages of Territory, Authority, Rights}

To do this, however, means engaging with some rather sticky terminology. As Randall Germain (2010) notes, there is no fault line within political analysis that "causes more analytical difficulty than that between the national or international, or between the

32 As Lapavitsas (2013) notes: "Marx's theoretical emphasis on 'monied' capitalists reflects the influence of classical political economy and should be treated with caution. Relative remoteness from productive activities and a potentially predatory outlook are important features of the lender, but the relationship of lender to borrower is considerably deeper ... The accrual of interest, furthermore, is hardly limited to a distinct section of the capitalist class that owns capital available for lending. In mature capitalism the typical lending agent is a financial institution that lends money capital collected across the capitalist class, and even across other classes. The concept of the 'monied' capitalist has limited explanatory power over the lending phenomena of financialized capitalism" (p. 115). 
domestic and the global" (p. 101). Indeed, the entire debate as to whether globalization is a novel epoch within the history of capitalism tends to hinge on whether the capitalist mode of production (and thus, capital) is understood as still being organized along national lines or in the process of becoming global. Instead, I want to make the argument that the national and the global are actually different property regimes. Doing so should make clearer the extent to which the role of the nation-state is transforming today. To do this, however, it might first be useful to reflect on some of the problems with using the concept of a mode of production as a tool of periodization, as is currently done by many scholars in the globalization debate.

The mode of production was a concept created by Marx (1978b) to explain the emergence of capitalism and to distinguish it from other historical forms of the division of labour, mainly feudalism. ${ }^{33}$ It refers to the combination of the productive forces (raw materials and labour power) of an age along with its associated property relations, which are "but a legal expression" (p. 4) for production relations. The concept emerged out of Marx's earlier critiques of Hegel and the classical political economists for their failure to explain the emergence of 'civil society,' the sphere of private interests that we would later come to refer to as the capitalist economy. ${ }^{34}$ Where these other theorists sought to explain the emergence of this type of society on the basis of human nature or the development of

33 As Marx and Engels (1932/1978b) note in The German Ideology: "the various stages in the development of the division of labour are just do many different forms of ownership, i.e., the existing stage in the division of labour determines also the relations of individuals to one another with reference to the material, instrument, and product of labour" (p. 151).

34 Marx (1932/1978c) writes, for instance, that classical political economy "proceeds from the fact of private property, but it does not explain it to us" (p. 70). To do so, as Marx (1847/1955) notes in an argument with Proudhon, is "to try to give a definition of property as an independent relation, a category apart, an abstract and eternal idea, [it] can be nothing but an illusion of metaphysics and jurisprudence" (p. 154). 
the human mind, Marx (1859/1978b) argued that it was instead the result of a change in "the material conditions of life" (p. 4); the result of the long process by which mobile private property came to dominate feudal landed property. ${ }^{35}$

The concept's major innovation (and one that still holds true) was the idea that all human communities are structured by their respective property relations, which are the historically specific social relationships that "govern the relative allocation of rights, responsibilities, and access to particular things" (Prudham \& Coleman, 2011, p. 7). These relationships were seen as necessary for Marx since they constituted the rights, claims, and entitlements "to the use and disposal of those goods and services essential to the reproduction of the social unit" (Teeple, 2007, p. 136); in other words, who gets what and how. In ordering the relations that members of a social formation have to one another in respect to the social product (i.e., the totality of what is produced) property relations were also understood to be relations of power. State forms were not to be understood on their own, but rather, as a reflection of the prevailing property relations; as Marx (1844) put it: "the state and the organization of society are not two different things. The state is the organization of society" (p. 8). In this view, the state does not possess any 'content' of its

35 In The German Ideology, Marx and Engels (1932/1978b) write: "In the case of the nations which grew out of the Middle Ages, tribal property evolved through various stages - feudal landed property, corporative movable property, capital invested in manufacture - to modern capital, determined by big industry and universal competition, i.e., pure private property, which has cast off all semblance of a communal institution and has shut out the State from any influence on the development of property. To this modern private property corresponds the modern State, which, purchased gradually by the owners of property by means of taxation, has fallen entirely into their hands through the national debt, and its existence has become wholly dependent on the commercial credit which the owners of property, the bourgeois, extend to it, as reflected in the rise and fall of State funds on the stock exchange. By mere fact that it is a class and no longer an estate, the bourgeoisie is forced to organize itself no longer locally, but nationally, and to give a general form to its mean average interest. Through the emancipation of private property from the community, the State has become a separate entity, beside and outside civil society; but it is nothing more than the form of organization which the bourgeoise necessarily adopt both for internal and external purposes, for the mutual guarantee of their property and interests" (pp. 186-187). 
own, but is defined by the system of rights that it enforces and defends. The underlying motor that drives history forward is thus the struggle between different social classes or groups as they attempt to challenge the existing system of rights; and as these rights are transformed, so too are the role and 'shape' of political institutions. To put Marx's theory simply, the history of rights is the history of changing modes of production and their respective social relations.

Marx's most in-depth analysis of a mode of production can be found in the three volumes of Capital in which he provides an analysis of the capitalist mode of production using the example of a closed, homogenous, capitalist economy. This example causes significant problems when it is used to explain the organization of the global political economy, however, because, as Brewer (1980/2002) notes, within the theory "there is no space for any differences in economic conditions between different countries" (p. 26) nor any recognition that within countries there are often multiple modes of production, and thus, different types of property that co-mingle within a specific social formation. These issues are compounded by the fact that Marx often failed to follow his own periodization schema, preferring to explain the different stages of social life not in terms of their unique property relations, but rather, by their characteristic methods of production (Balakrishnan, 2015). These problems have since led to a situation in which the mode of production is currently used to support two conflicting positions: (1) that globalization is nothing new since the dominant mode of production remains capitalist; and (2) that globalization represents epochal change because production relations are moving to the transnational lev- 
el. ${ }^{36}$

To transcend this issue, I suggest that we blend Marx's very valuable insights into

the organizing role of property relations with the analytical/conceptual framework of the world scale developed by Saskia Sassen (2006) in Territory, Authority, Rights. Sassen's

main contention is that many globalizing processes do not necessarily scale at the global

level, but are instead located within national domains and remain coded as such. This

means that we cannot rely on labels like national or global to indicate the specific level of

operation. Sassen suggests instead that we treat the national and the global as different

assemblages of territory, authority, and rights (or, TAR) by virtue of their transhistorical

character. ${ }^{37}$ By disaggregating the national and the global into these different elements,

Sassen is able to avoid comparing them as complex wholes and instead treat them as rela-

tional systems whose capabilities (defined as institutionalizations of TAR) eventually

36 Some theorists argue, for instance, that globalization is nothing new because the phenomenon does not alter or disrupt the basic property relations of capitalism (e.g., (e.g., Lacher, 2006; Teschke \& Lacher, 2007; Tabb, 2009; Wood, 1998, 2007). In my view, however, this overlooks the many changes to property over the history of capitalism that have significantly altered how that mode of production functions and is organized over time. A great example of this is the coming of the modern corporation, which fundamentally transformed "the nature of the rights, entitlements, and obligations bundled with the ownership of productive enterprises" (Roy, 1997, p. 11). As Henwood (1998), notes, the shift from direct ownership to the ownership of shares "enabled a whole class to own an economy's productive assets, rather than being bound to a specific property as they once were" (p. 13). The emergence of the modern corporation thus made possible a "tremendous expansion in the scale of production and enterprises which would be impossible for individual capitals" (Marx, 1894/1991a, p. 567). Only in the most general, abstract sense is capitalism the same thing down through the ages. Differentiating modes of production at such a high level of abstraction (as is done in the globalization debate) thus fails to address the need to distinguish changes within them; especially those that have a significant impact on how people are able to reproduce their lives.

37 Although Sassen (2006) claims that her use of assemblage here simply refers to the dictionary definition, there are similarities between her thinking and a number of other theories, such as Manuel Delanda's (2006) assemblages theory of historical ontology; Neil Fligstein's (2002) theory of the state as a field; and Katherine Thelen's (2004) version of historical institutionalism. As Daniel Little (2016) notes, the idea at root of these theories is "that institutions and social entities are created and maintained by the individuals who interface with them, and that both parts of this observation need explanation" (para. 3). In my view, however, fragments of property weave their way through all social institutions and interactions. As such, I believe that all these approaches are essentially circling around the reality of what Marx discovered in the 19th century: that all societies are defined by their respective property relations. 
reach tipping points that lead them to jump tracks and support a new organizing logic. In this schema, tipping points refer to events, defined "by their significance as markers of transition" (Abrams, 1982, p. 195). They are, in Sewell's (1996) terms: "sequences of occurrences that result in transformations of structures" (p. 843). Organizing logics are defined as the prevailing dynamic through which capabilities are institutionalized. Sassen identifies three: the centrifugal logic of the medieval epoch, consisting of several encompassing normative orders; the centripetal logic of the national epoch, consisting of one master normativity; and the centrifugal logic of the global that is currently in the process of separating that master normativity "into multiple partial normative orders, thereby leaving open the question as to its sustainability" (p. 10). In taking such a macroscopic view, Sassen (2006) goal is highlight the "foundational differences between the world scale of several earlier phases of the world economy and today's global economy" ( $p$. 14). The real benefit of her approach, however, is that it "keeps us from having to posit the ascendance of a new order necessarily means the end of the old order" (p. 9).

Despite being critiqued for her lack of class analysis (Robinson, 2009), Sassen's approach can readily incorporate Marx's insights into property, since any property regime implies a territory over which rights apply, an authority to enforce them, and a particular type of right, claim, or entitlement. As numerous scholars note, forms of territory, authority, and rights are all constituted by the very property relations that give them substance and meaning (e.g., Blomley, 2011, 2015; Lacher, 2006; Macpherson, 1978; Polanyi, 1944/2002; Prudham \& Coleman, 2011; Teeple, 2005a, 2007; Teschke \& Lacher, 2007; 
Winters, 2011).$^{38}$ For instance, as Jeffrey Winters (2011) notes in his book Oligarchy, all historical political systems are, in essence, forms of wealth defence that exist to defend the prevailing property relations of the ruling class. The transformation of property relations, however, might bring forth a new ruling class and the subsequent transformation of the political system, as can be seen during the American, French, Russian, or Chinese Revolutions (Carruthers \& Ariovich, 2004). Similarly, Prudham and Coleman (2011) note that territory is always "the spatial expression of power relations in general and the more specific expression of property rights and their administration in the delineation of particular spaces" (p. 13). This is because all property regimes "involve the geographic extension of social relations and institutions and to geographic integration via the articulation of disparate places under more or less common (though by no means homogeneous) modes of governance" (p. 14). As geographer Nicholas Blomley (2011) puts it: property, at its very core, "involves boundary-work, in which both bounded and relational spaces are at work" (p. 205). Indeed, as Prudham and Coleman (2011) note, property not only links the "spatial dynamics of what goes on between states with what goes on within states" (p. 13), but is also "critical in the demarcation of coherent periods (longues durées) of global integration, disintegration, and hegemony" (p. 15).

Sassen's (2006) main claim - that “each mode of politico-economic organization embodies specific features when it comes to territory, authority, and rights" (p. 32)—is thus one that reflects the centrality of property to all forms of social organization, and

38 In a recent article, Jordan Branch (2016) does well to note the significance of territory as an institution, and the extent to which it sits at the intersection of ideas about political space, practices of political authority and rule, and technologies relating to information and infrastructure; but he fails to highlight the extent to which these things are tied to the specific way in which the ownership of property takes place. 
therefore, the structured and organized ways in which the accumulation of capital has taken place historically. As political theorist Andrew Reeve (1986) notes, it is property that "provides the links between an economic system, a legal system, and a political system" (p. 7). According to the anthropologist C.M. Hann (1998), this is why property works well to "facilitate comparative analysis in the fields of social organization where economics, politics, and law intersect" (p. 5). Against the idea that capitalism is simply a mode of production constituted by surplus extraction through the market, Sassen's (2006) framework allows us to be far more specific by zooming in on the specific configurations of rights that have constituted different ways of organizing the accumulation of capital over time. As she notes, this approach not only "produces an analytics that can be used by others to examine different countries in the context of globalization," but also "different types of assemblages across time and space" (p. 5).

This consideration of both time and space matches up well with the overlapping nature of historical change that Massimiliano Tomba (2013) has identified in Marx's historiography. Using a geological metaphor, Marx (1881) makes clear that the long transition from common to private property does not exist in distinct stages (as when the mode of production is used to periodize) but rather "as in geological formations, these historical forms contain a whole series of primary, secondary, tertiary types, etc." (para. 41); in other words, they always overlap. Sassen (2006) makes a similar point: once when she criticizes world-system theorists for assuming that competition and market forces have been in existence prior to the emergence of capitalism (p. 75); and again, when she highlights how the elements of the new order emerge out of the old. As she points out, during the 
early days of capitalism, "kings, nobility and the church were the dominant actors, obscuring the fact that capitalism was in the making" (p. 85); similarly, "even as industrial capitalism was becoming the dominant dynamic, most people, most firms, and most political debates were not centred on it. Objectively the prevalent condition remained agriculture and trade" (p. 420). By disaggregating the national and the global into their component parts, we are thus able to better register those elements that although still labelled national, might instead be supporting a global organizing dynamic. While the organizing logics of both the national and global epochs of capitalism are constituted by states and world political economies, they are each aligned in different ways and with different outcomes. The emphasis, here, is thus on getting away from the view that is so common in the debates over globalization, "that the sum of a given set of parts inevitably produces the same key assemblage" (p. 15). As Sassen (2006) notes, however, this can only be done by demonstrating how "key capabilities developed in an earlier phase can become foundational to a subsequent phase but only as part of a new organizational logic that in fact also foundationally repositions those capabilities" (p. 15).

For our purposes, that means focusing on the nation-state as a capability for the expansion of capital. If we view the nation-state as a particular assemblage of territory, authority, and rights, then it becomes possible to see that what we refer to as globalization is starting to reconfigure this assemblage. While the nation-state still exists, specific elements of TAR are being organized in different ways and with different outcomes than in the past. If the beginnings of capitalism consisted of stretching private property rights across the many jurisdictional boundaries of the medieval epoch, transforming the role of 
state institutions in the process, then it does not take a great leap of faith to see that the extension of the rights of capital today across multiple nation-state jurisdictions might form the basis for a similar sort of reorientation. ${ }^{39}$ In my view, we should treat this 'upward' movement of the rights of capital as the basis of an emerging transnational state; this is because it ends up transforming the nation-state from a capability to grow and develop local capitals into a capability for globalizing capitals by restricting the ability of the nation-state to limit the rights of corporations. As we will see in the following chapters, nothing illustrates this transformation more clearly than the history of the Royal Bank of Canada.

\subsection{Conclusion}

Against Canadian theories of imperialism and dependency that continue to base their claims off of an historically-inaccurate view of the role of banking and finance in the transition to capitalism, this chapter set out to provide an alternative framework that

39 After the emergence of capitalism in England, France and the other continental monarchies were pressured to transform their own property regimes, a process which took both economic and political paths. As Teeple (2000) notes, both "amounted to the abolition of 'internal' tariffs, tolls, customs duties, and the destruction of precapitalist property relations, among other barriers to a 'regional' free-trade system" (p. 156) - what would ultimately become the territory of the modern nation-state. After the French Revolution, for example, one of the first tasks was the creation of a national market "out of the numerous regional and jurisdictional divisions that characterized France and thwarted its economic development" (p. 156). In contrast, Teeple (2000) points to the German Zollverein of 1834, which was a "customs union initially uniting some eighteen states, principalities, cities, and other jurisdictions, and it preceded political union" (p. 156). There are a many other examples of customs unions preceding the nation-state throughout much of Europe (Pollard, 1974). In spite of the path taken, both provided the basis for the further development of national capitalist social relations by reorienting the role of already existing territorial absolutist states toward the creation and protection of new rights that stretched across the overlapping jurisdictional boundaries of the medieval era. As Heilbroner (1986) notes, a fundamental part of this process was the increasing recognition of clear constitutional "constraints on the power of the state to violate the private space of the individual or to commandeer his or her property" (p. 89). In the process, the state lost its direct access to the surplus. The transition from feudalism to capitalism can thus be understood as a process by which the institutions of absolutist states were slowly shifted toward the legitimation and protection of new forms of individual private property. 
understands epochal-level change as resulting from significant changes in the way in which property relations are configured. Through an analysis of Marx's writings on property, I argued that a clearer case can be made for the transnational state on the basis of the movement of the rights of capital to the transnational level. To make the extent and depth of this transformation clearer, I suggested blending Marx's insights into property with the work of Saskia Sassen (2006) to conceptualize historical property regimes as assemblages of territory, authority, and rights. The purpose of the chapter was thus to setup a framework for analyzing the history of the Royal Bank of Canada so that we can better register the qualitative changes that are beginning to mark our emerging global epoch.

The reason for demonstrating why and how the expansion of capital over the 20th century has resulted in the emergence of a novel global organizing dynamic is to make clear that there are significant problems with continuing to understand the global political economy within a core-periphery model of the world economy. Indeed, as I hope to show in the following chapters, the construction of a global system of rights for capital greatly problematizes the extent to which we can understand globalization in national terms, even though many globalizing processes are located within national domains and remain coded as such. Having a better understanding of this general process will thus enable us to have a better understanding of the normative implications of these changes moving forward. What follows in the next four chapters is a grounding of my approach in respect to the long-term transformation of Canadian banking via the history of the Royal Bank of Canada. The attempt is to distinguish a period of time that we can refer to as the national epoch of capitalism and an emerging global epoch of capitalism that is representative of a 
shifting of those particular elements of territory, authority, and rights that were crucial to the earlier period. 


\section{Making National Capital: The Origin of the Royal Bank of Canada,}

\section{4-1939}

What is in the interest of the country is in the interest of the banks.

—Charlie Neill, General Manager of the Royal Bank of Canada, 1924.

\subsection{Introduction}

Theories of Canadian imperialism and dependency begin by asking whether Canada is among the dominant or dominated powers in the global political economy. They are built on an understanding of the global political economy as composed of competing national capitals and states. As I pointed out in the second chapter, however, significant changes to the global political economy over the last 40 years have started to challenge the fundamental units of these theories. In this chapter, I attempt to set up a historical foil by which to compare the national and global epochs of capitalism. My goal, here, is not to argue that these theories are wrong, but rather, that the basis on which they were constructed is now changing. In other words, while these theories might have made sense to explain a world made up of competing national capitals, this is no longer the case. Rather than asking whether Canada is dominated by local or foreign capitalists, I want to ask instead how this earlier period in Canadian history-which often constitutes the basis for many theories of imperialism - differs in its fundamental configuration of territory, authority, and rights (TAR) in respect to capital today? How were the property relations that sustained capitalism during this period organized, and how did they contribute to the making of what we have come to call national capital? 
The reason for asking these questions are because, as Sassen (2006) notes, there has been "a sort of capture by the nation-state frame of much of the post-sixteenth century history in the West" (p. 7). What she means is that since "the ascendence of the nation-state and its capture of all major components of social, economic, political, and subjective life" (p. 9) there has been a tendency to treat the nation-state as if it has played the same role historically; that, simply because it is still here, it somehow provides the basis for the same sort of organizing dynamic that characterized this earlier period of imperialism and capitalist nation-building. What I seek to demonstrate throughout the following four chapters is that this is not the case; that the assemblage of TAR that sustains global capitalism today is indeed changing in epoch-defining ways that increasingly reduces the meaning and efficacy of Canadian liberal democracy.

In this chapter, I explore how this earlier period of TAR was configured in Canada. I do this using the framework I set up in the last chapter for the analysis of globalization vis-à-vis a case study of the transformation of the Merchants Bank (later, the Royal Bank of Canada). That framework can be summarized by saying that the history of TAR is a reflection of the history of changing modes of production and their respective social relations. I argue that the late 19th and early 20th century can be distinguished by virtue of the creation of a national system of property relations; that is, by a clear centripetal organizing dynamic of TAR toward the national level. In stating this, I do not wish to suggest that capital was the primary causal actor in this process; as others accurately note, the territorial state existed long before capital did (Lacher, 2006; Teschke, 2003; Wood, 2002a). Rather, what I wish to highlight is that this earlier period 
can be distinguished from our own by the movement of the rights of capital and the authority over those rights to the nation-state level; more specifically, in the case of banking, this meant that "the principal foundations of financial governance . . . were organized around national institutions" (Germain, 2010, p. 25). I identify four shifts in TAR - Confederation and the Bank Act, the National Policy, the Finance Act, and the Bank of Canada - that represents this drawing in as it relates to the chartered banks. What was the overall result of this organizing logic? To provide the chartered banks with the capability to grow via both expansion and protection. As I demonstrate in later chapters, the development of this capability is a crucial factor in the transition to our global epoch.

The chapter proceeds as follows. First, I introduce the Merchants Bank and give a brief overview of the character of pre-Confederation banking. Next, I focus on each of the shifts in TAR noted above and explore their effects on the Merchants' structure, operations, and activities. Special attention is paid to the specific nature of the conflicts between the Merchants Bank, the other chartered banks, and provincial and federal governments. I argue that these shifts in TAR represent the growth of capital during a particular stage in its historical development; as such, I conclude that we should understand this period of capitalism as the making of what is commonly referred to as national capital.

\subsection{Pre-Confederation Banking and The Merchants Bank}

Any system of property relations is constituted by a system of enforceable (property) rights or claims within a given space; these relations subsequently give a social 
formation its particular shape and dynamic. The constitution of these rights is not the outcome of some efficient process, but rather, a continuous and contestable social and political struggle in which organized groups (whether from business, labour, government, or elsewhere) try to affect the outcome (Fligstein, 2002, p. 33). In this sense, state building is the historical process by which certain groups are able to get the state to make rules that benefit their interests; these rules subsequently reflect the interests of what we can consider the ruling class. These rules include not only what can be owned and exchanged (e.g., land, labour power, money) but the right to pool individual capitals together into corporations which are legally understood as fictitious individuals. ${ }^{40}$ As Clement (1979) notes: "corporations are legal fictions, the creatures of property relations endowed with the rights of capital" (p. 232). Policies that function to regulate corporations also fall under the theoretical ambit of property relations since they are rules that regulate what can be done with what is owned. Given the specific nature of the property relations of the early Canadian colonies and their respective social dynamics, a centripetal logic of TAR was already well underway by the time the Merchants Bank was founded in 1864. Briefly describing the nature of these property relations and how they shaped the character and dynamics of pre-Confederation banking will help us reflect on the making of the national assemblage of TAR and the wider significance of this shift.

From the Treaty of Paris until Confederation, the British territories in North America were independent colonies. They were almost completely separate and

40 Mozley \& Whitely's Law Dictionary (1977) defines the corporation as: "a number of persons united and consolidated together so as to be considered as one person in law, possessing the character of perpetuity, its existence being constantly maintained by the succession of new individuals in the place of those who die, or are removed" (p. 82). 
communicated directly with the British government rather than with each other. They were ruled by an oligarchy of colonial officials and merchants-'gentlemanly capitalists' - whose wealth was rooted in office, trade, and land. ${ }^{41}$ Where the newly independent American colonies had been oriented toward settlement, the remaining colonies of British North America were "basically a source of raw materials" (Clement, 1977, p. 35). As such, their legal and regulatory framework was one "conceived, planned, and developed to suit the great extractive monopolies belonging to the financial oligarchy" (Deneault \& Sacher, 2012, p. 184). The ability of this oligarchy to gain such wealth was the result of the so-called 'rights of Englishmen' that constituted the basis for the emergence of capitalism in both England and its various colonies, as well as the transformation of the absolutist state (Blackstone, 1753/1893; Macpherson, 1962; Wood, 2002a). These rights were essentially hard property rights - "the concrete rights of ownership, control and conduct, earned by struggle and competition" (Lower, 1945, p. 111) — and they allowed these gentlemanly capitalists to justify their appropriation of most of the arable land in the colonies and the subsequent exploitation of their resources for the purpose of making money by trade, especially via the early merchant corporations like the Hudson's Bay Company; as Deneault and Sacher (2012) note, this ruling class

41 The term 'gentlemanly capitalists' is a reference to P.J. Cain and A.G. Hopkins $(1986,1993)$ who argue that the role of industry in the emergence of British imperialism is overstated. They instead point to the importance of the British gentry and their shift from rentier capitalism to commercial agriculture, and from there, to the domination of the financial service sector. They claim that these 'gentlemanly capitalists' retained a leading role in the military, parliament, House of Lords and cabinet until late into the 19th century. For more on these gentlemanly capitalists and their role in creating capitalism in Canada, see Myers (1914/1972), Schrauwers (2008, 2009), Teeple (1972), and Woodcock (1989). 
did not come to Canada "to create a specific nation, even less to establish a sovereign republic: they came to strip a territory of its resources" (p. 180). ${ }^{42}$

These property rights were thus not only central in allowing the colonial ruling class to exploit Canada's various staples, but were a central part of British financing to its various colonies, since "investment ultimately transferred property overseas and nothing was more fundamental to investors' interests than the security of that property" (Dilley, 2012, p. 71). As such, the role of both the early colonial states, as well as the postConfederation Canadian nation-state, was the protection of these rights, and thus, those classes that benefitted from them. ${ }^{43}$ Indeed, as Heller (2012) notes: "capitalism in Canada grew under the protection of the Canadian state through the establishment of a legal system protecting private property, the privatization of land and natural resources" ( $\mathrm{p}$. 227). This follows from the more general historical point, explicated in the last chapter, that "the state had to be based on territory because of the rise of private property and the social consequences of this change" (Draper, 1977, p. 253). As the British empire

42 As Jenkins (1996) notes: "when they took over management of new land in their rash of colonization, the British exported the doctrine of enclosure" (p. 101). Teeple (1972) provides a brief description of the period: "the genesis of the mercantile capitalist in Canada is found in the British merchants at the time of the Conquest. Like so many vultures, they 'were first at Quebec at its fall' and then followed the troops to Montreal, where they established their colonial headquarters for the fur trade. The position of this merchant class was central in the new colony as a result of its 'alignment' with the military government. A unity of interests was to be expected, for one motive of the military conquest was to seize the profitable fur trade. This oligarchy of colonial officialdom and merchants soon appropriated the land by way of gifts and grants. Thus, the wealth and power of the ruling class in the British North American colonies came to be founded in office, trade, and land" (p. 61). As such, both colonial administrators and merchants had no particular concern for the welfare of the colonies: they were valuable only insofar as they "magnified imperial wealth and power" (Pentland, 1981, p. 151).

43 Naylor's (1975/1997) early research makes a good case for this perspective: "Many of the most critical political decisions taken by the ruling class in the colony were conditioned by the state of Canada's relations with the British capital market. British capital built most of the major works of commercial infrastructure in the provinces; public finance depended upon the pleasure of the imperial government and the London private 'merchant' banks; and Canadian development policies and the structure of its capital markets and financial institutions were moulded to ensure the greatest facility of entry of British capital" (p. 20). 
continued to expand these property rights were stretched across other territories (such as the Caribbean) thus providing Canada's ruling class with numerous opportunities for protected accumulation activities.

Having begun the process of colonization during the transition from mercantilism to capitalism, however, the colonies were still governed by a variety of legislative orders that applied to different phenomena in an uneven manner. ${ }^{44}$ This system of differential rights and duties was, as Sassen (2006) notes, a holdover from feudalism that was only beginning to change in earnest by the late 18th century (pp. 25-73). The right to issue promissory notes, payable on demand, for circulation as money, for instance, was not originally the exclusive right of the government or Crown, either in Great Britain or the colonies, but rather, the common law right of those that chose to exercise it. As a result, the early colonial banks were made up of groups of merchants who simply organized themselves into co-partnerships. Unlike the conception of banks in the classical theories of imperialism, these banks did not emerge to fund nascent manufacturing industries, but rather, to facilitate "the movement of staples from Canada to external markets" (Naylor, 1975/1997, p. 67). In a more recent analysis, business scholar James L. Darroch (1994) makes the case that:

44 Pentland (1981) provides a description of its general effect on class in the Canadian context: "In the eighteenth century, and in the first half of the nineteenth century in most parts of the provinces, there was a general acceptance of a class structure derived from, though no less clear cut than, European ones, that involved differential rights and duties, and criteria of loyalty and 'respectability' rather than of merit by some objective test or success in the marketplace. Until about 1840, the privileged and educated and their supporters were quick to emphasize that Canada was substantially free of the democratic practices of the barbarous Americans and, therefore of the mob rule and thoughtless measures which they produced. The determination of policy by those born and trained to rule implied the denial of role not only for the masses but for 'natural' laws and forces" (pp. 159-160). 
The Canadian banks were from their origin involved with the financing of tradethat was their raison d'être. In order to provide this service, they had no choice but to adopt an international focus and to develop the skills demanded of a multinational bank. This required the early establishment of operations in New York, London, and often Boston. In this context, the position of Canada as a natural intermediator between Great Britain and the United States should be recognized (p. 4).

As the general scale of capital accumulation grew over the latter part of the 18th century, these merchants began to petition the Crown for charters of incorporation-in other words, new rights - that would allow them to overcome the limits of the partnership form. ${ }^{45}$ It is thus no surprise that one of the earliest references to banking came from Lower Canada — then, the dominant commercial colony in what is now Canada—in 1792 when "some gentlemen of Montreal decided to establish a bank under the name of the Canada Banking Company. Only a private bank of deposit, however, resulted from this effort" (Curtiss, 1939, p. 151). In 1808 there was another attempt to establish a bank in Lower Canada after a charter was requested from the legislature, but it was not granted by the Crown. With the lack of currency a significant issue in Lower Canada, the Bank of Montreal was organized under articles of association in 1817. A charter was requested in

45 As Teeple (2005b) notes: "the corporate form emerged with the growing accumulation of capital and the consequent need to have a structure that reflected this accumulation and its continuous expansion" (p. 93). "The absolutist state was responding to and promoting a logical growth in the nature of private property, its aggregation; this socialized capital was the only way of overcoming the serious limits to the development of the productive forces presented by pre-capitalist petty commodity production" (p. 95). 
1818 , "but reserved by the governor for the significance of the royal pleasure. The royal assent was withheld and the Bank of Montreal continued as a private partnership" (Breckenridge, 1894, p. 25). In 1818 the Quebec Bank was also started, along with the Bank of Canada (not to be confused with the central bank created in 1934) but both were similarly denied charters.

In the winter of 1820 , the shareholders of each of the three banks "again petitioned the legislature to be erected into bodies corporate and politic" (as cited in Breckenridge, 1894, p. 21). They argued that "without the benefit of incorporation, the beneficial purpose contemplated by the establishment of the banks would be imperfectly attained, and great inconveniences would be incurred in the conduct of their business" ( $p$. 21). The benefits were then, as now, fairly obvious. Private partnerships had no public shareholders; any partners were thus personally responsible for all of the company's debts. They also could not hold any property; and without a separate legal personality, they could not sue or be sued. ${ }^{46}$ Receiving incorporation was thus a necessary precondition for the investment needed to expand. The banks "prayed, therefore, to be incorporated under regulations and provisions as nearly corresponding with the terms of their original association as it might be, and under such other regulations and provisions

46 In its modern form, the corporation is a legal entity that is effectively recognized as a fictitious person under the law, possessing certain civil rights. Modern incorporation thus provides many benefits including: (1) the protection of personal assets against the claims of creditors and lawsuits; (2) the ability to easily transfer ownership; (3) the ease at which retirement funds can be established; (4) lower rates of taxation; (5) the ability to raise funds through the sale of stock; (6) durability over time; and (7) the ability to secure a credit rating independent of the status of shareholders and directors (see, e.g., Berle \& Means, 1932/1968; Chandler, 1977; Monks \& Minow, 2011). Like earlier corporate entities, the modern corporation has been utilized for a number of different purposes, including the provision of large, public infrastructure projects (Schrauwers, 2008, 2010; Soederberg, 2010; Roy, 1997). Since the late 19th century, however, it has mainly become a vehicle for the accumulation of capital (Fligstein, 2002; Henwood, 1998; Veblen, 1904/2005). 
as the legislature might prescribe" (p. 21). On March 17th, 1821, "the prayers of the petitioners were granted" (p. 22). Three charters incorporating the banks were presented by the legislature for royal assent. They were reserved by the governor for over a year and became law in 1822.

In Upper Canada the first bank charter was granted in 1819 to the Bank of Kingston; the second in 1821 to the Bank of Upper Canada. The Bank of Upper Canada was a quarter owned by the colonial government and largely controlled by the Family Compact, a small group of gentlemanly capitalists who dominated political and economic life in Upper Canada. As Schrauwers (2008) explains:

The Bank of Upper Canada, the Clergy Corporation, and the Canada Company served as the financial backbone of the colonial state and of the small group - the Family Compact - that directed these closed institutions. The Canada Company provided the executive branch of government - the lieutenant governor and his executive council—with revenues independent of elective control. The Bank of Upper Canada, as the largest creditor in the province, effectively controlled the colony's money supply and through its note issues enabled mercantile domination of trade and the land speculations of the Family Compact. These three chartered corporations represent a delegation of state control to non-elective bodies that shielded their directors with separate identity and limited liability (p. 236).

The Bank of Upper Canada quickly gained a monopoly in the province after the collapse of the private Bank of Upper Canada at Kingston and the inability of the Bank of Kingston to start within the period of its charter. With control of the legislative council, 
the Family Compact was able to restrict efforts to obtain new charters; however, a financial crisis in 1821 and 1822 gave the assembly the opportunity to protest the Compact's monopoly and in 1832 another charter for the Commercial Bank of the Midland District was granted to the earlier financial interests associated with the Bank of Kingston. In 1830 the British government would attempt to issue instructions to the colonies as to what was desirable in a bank charter for the purpose of protecting British shareholders, but these instructions were not initially followed; later amendments were found to be more agreeable. ${ }^{47}$

Then, as now, each bank required a separate Act of incorporation; however, there was no general banking code so the charter essentially functioned as "the source of the bank's legal capacities" (Curtiss, 1939, p. 151). At the time, these corporate banking

47 As Curtiss (1939) notes: "Some dispute arose over these Acts [i.e., charters] in which the British government threatened to disallow them. Strong representations were made from Canada, however, and the Acts were finally allowed. But the British government stated that they would allow no further Acts (a resolution not strictly adhered to), unless they conformed to the set of instructions sent out in 1833, which contained the following provisions: (1) Suspension of cash payments for sixty days in the forfeiture of the charter; (2) Notes issued at any branch to be redeemable at the head office but not at other branches; (3) One-half the capital to be paid in immediately; (4) Loans to directors or officers (or on paper bearing their names) to be limited to one-third of the total advances; (5) No bank to hold its own stock or to lend on it; (6) A weekly statement of the bank's affairs to be made and a semi-annual statement to be sent out to the legislature; (7) Shareholders to be liable for the amount of their sharesthe 'double liability'; (8) Compliance with certain conditions in making loans - in general, to see that the bank remained a creditor and did not become a partner. These provisions have been set out in some detail to show the influence of the British government on Canadian banking development. The third, fourth, and eight provisions were already in operation, and the first practically so; the others were gradually inserted in the charters after this time, although it was not until after 1841 that all were included. Thus, while there was a local tendency towards better banking laws, the influence of the British government hastened and secured these sound developments" (p. 153). 
charters were "essentially a gift of the state" (Henwood, 1998, p. 253). ${ }^{48}$ They were basically "a licensed monopoly to which the Crown delegated specific aspects of its sovereignty" (Schrauwers, 2008, p. 254). While they all gave the banks a separate legal personality (and thus, the right to hold property, to sue and be sued, and, most importantly, limited liability for their British shareholders), the specifics of each charter were slightly different, and they were limited to operating within their respective colonies. We can take the Bank of Montreal charter as somewhat typical of the period:

(1) The directors were to be British subjects, and under certain conditions were individually and jointly liable for some actions of the bank;

(2) Shares were to be of 50 pounds denomination each, with graduated voting so that no shareholder had more than 20 votes;

(3) The corporation was empowered to sue and be sued in the corporate name; to issue bank notes payable on demand in legal coin; to receive deposits and to deal in bills of exchange, to discount notes, to deal in gold or silver bullion, and to sell stock pledged, but not redeemed; to have and to hold mortgages on real property for debts contracted to it in the ordinary course of its dealings, but not to lend on

48 As Teschke (2003) notes: "mercantilism meant essentially the private ownership and accumulation of state-sponsored titles to wealth for the mutual benefit of king and privileged traders and manufacturers" (p. 209). The early European chartered companies were thus "largely ways of rewarding court favourites, sycophants, and nobility, or as a way of raising revenues or advancing other private interests" (Teeple, 2005b, p. 95). They effectively functioned as extension of state sovereignty by virtue of the rights, powers, and privileges granted to them by their respective monarchs. Charles II of England, for instance, granted the Hudson's Bay Company in 1670 an exclusive and perpetual monopoly of trade and commerce; possession of the lands, mines, minerals, timber, and fisheries; full power to make laws, ordinances, regulations, penalties, and punishments; and the right to employ an armed force, appoint commanders, erect forts, and any other measures necessary for the protection of its trade and territory (Myers, 1914/1972, pp. 38-47). As Naylor (1972) notes, the success of these early chartered companies led to new class relations: "the nouveau riche merchants began congregating in the City of London where they soon became the chief lenders and funders of government debt" ( $p$. 4). 
mortgages or to purchase them; to hold real estate to the value of 1,000 pounds

annually and no more;

(4) An annual return was to be made to the shareholders (Curtiss, 1939, p. 152).

As Breckenridge (1894) notes, these government limitations were readily accepted by the colonies' merchants in return for "the concessions of incorporation, the currency of their notes in revenue, assured protection against forgery, the power easily to enforce stock subscriptions and the like" (p. 152).

The proliferation of orders that characterized the early colonial period would start to reverse with the unification of Upper and Lower Canada in 1841 and the move away from mercantilist policies by the British, as represented by the Reform Bill of 1832 and the repeal of the Corn Laws in 1846. The Act of Union was itself the result of the rebellions of 1837 and 1838 and the subsequent collapse of the provinces' commercial credit in Britain; the expectation was that "spreading the burden of repayment of the bankrupt upper province's debts over the population of the almost debtless lower province would both reassure existing British debenture holders and widen the revenue base for future issues" (Naylor, 1975/1997, p. 22) ${ }^{49}$ As part of unification, there began a process of standardizing the existing bank charters, as well as of extending "the corporate powers of each bank to the whole province" (Breckenridge, 1894, p. 90). This not only opened up the territory in which the banks could operate, but preserved "the monopoly held by the few chartered banks in Canada" (Myers, 1914/1972, p. 100). The Act of Union also signalled the start of a long struggle (discussed later in this chapter) to transfer

49 As Clement (1975) notes, the debts of Upper Canada came from the construction of canals to export staples, a further example of the period's dynamic of accumulation (p. 54). 
the chartered banks' right to issue notes to the state. The Free Banking Act of 1850 , which was a failed attempt to replicate the United States unit-banking system, was similar in this respect; however, it was also the first Act that applied to all the banks equally, a feature that would later come to characterize the post-Confederation banking order. Changes to the Bank of Montreal's charter in 1854 were also extended to the other chartered banks, further indicating a shift toward a standardized system (Curtiss, 1939, p. 154). The note issue problem would arise again in 1866 after the failure of the Bank of Upper Canada and the Bank of Montreal's refusal to loan the government more money. ${ }^{50}$ In response, the government passed the Provincial Note Act in an attempt to link the note issue to the needs of the British administration by granting the province a monopoly on the issue of one- and two-dollar notes; there was also another attempt to create a central bank for the same purpose, but it too would fail. If, as Teeple (2007) notes, "the distribution of power over the means of production and share of the social product are expressed in the form of prevailing rights" (p. 136), there can be no doubt of where the Province's chartered banks stood at the time of Confederation: their corporate power was unmatched.

In Nova Scotia, the situation was slightly different. Nova Scotia was a relatively self-contained colony run by merchants for merchants; as such, there wasn't the constant tension between the colony's merchant class and the imperial government as compared to

50 "The government in which the Honourable (afterwards Sir) A.T. Galt acted as Minister of Finance, was obliged in 1866 , to raise some $\$ 5,000,000$ to discharge the floating debt. The credit of the province had suffered in the English market on account of the renewal, from time to time, of the balances in arrears. The Minister averred that the Canadian banks were unwilling to extend to the government a loan amounting to $15 \%$ of their capital. The Bank of Montreal was already a creditor for $\$ 2,250,000$, and was pressing for payment. The government would not trust to the chance of meeting the engagements of the country by large loans at high rates of interest" (Breckenridge, 1894, p. 136). 
Upper and Lower Canada, where the interests of the Family Compact and Château Clique were often in opposition to the desires of the imperial government and of economic development in general. The Bank of Nova Scotia was first chartered in 1832 and the trend soon caught on; with only slight adjustments in 1847 and 1856, later charters incorporating a number of other Nova Scotia banks were almost identical. All were merchants banks, "offering to discount bills, to handle foreign exchange, and to take deposits at 3\% per annum" (McDowall, 1993, p. 21). None of the Nova Scotia merchant banks failed prior to Confederation; as Breckenridge (1894) notes: "the banking system as originally worked out caused so few difficulties and promoted so much the convenience and prosperity of the colonies, that they felt very little temptation to change it" (p. 162). The private banks carried on all branches of banking, including note issue, in competition with the chartered banks. In both cases, "their proprietors were men of wealth; they enjoyed the confidence of the community, and conducted their business according to recognized banking principles" (p. 162). "The banking history of Nova Scotia," as Breckenridge (1894) notes, is thus "not eventful" (pp. 162-163).

The Merchants Bank was one of these private banks. Formed in 1864 by a group of wealthy Haligonian merchants-J.W. Merkel, Edward Kenny, T.C. Kinnear. John Duffus, William Cunard, John Tobin, George P. Mitchel, and Jeremiah Northup-the bank was a response to Halifax's growing prosperity as a result of the outbreak of the American Civil War. Like all the colonial banks, they were mainly involved with the financing of trade; however, being a Nova Scotian bank, they were more closely oriented toward the sea, existing as they did "on the margins of a vast imperial trading 
system" (McDowall, 1993, p. 16). Their initial role was to connect the vast mercantile flows of wealth connecting London to Canada and the West Indies under the protection of the British empire, acting chiefly as an agent for larger banks involved in the staples trade such as the Imperial Bank in London, the Union in Newfoundland, the Union in Prince Edward Island, and the New Brunswick Bank. By late April of 1864, the Merchants had put advertisements in the local press announcing their services: the discounting of promissory notes and acceptances, advances on approved securities, the purchase and sale of bills of exchange, and the depositing of money. With a capital base of only $\$ 200,000$ the Merchants rented the old Bank of Nova Scotia offices on Bedford Row; as of May 2nd, 1864, the Merchants Bank was open for business.

Unlike incorporated entities, co-partnerships like the Merchants "had no public shareholders nor any obligation to explain itself to the mercantile community it served" (McDowall, 1993, p. 24). They had no separate legal personality, and thus, could not hold property, could neither sue nor be sued, and all shareholders were personally responsible for all debts of the company. "Anchored in law in only the flimsiest of ways" (p. 16) and with little to no commercial information to rely on, the members of a co-partnership "had no option but to proceed on the basis that a man's word was his bond" (p. 18); as a result, partnerships "formed and broke apart with great regularity" (p. 16). This older style of banking would all change, however, with Confederation and the creation of the Canadian nation-state, which would set off a series of shifts in TAR that would greatly improve the Merchants' capacity to accumulate capital-albeit, at the economic expense of their home region. 


\subsection{Confederation and the Bank Act}

While a centripetal organizing dynamic of TAR was already in the works before Confederation, it would be greatly accelerated by the creation of the new Canadian nation-state, the Dominion of Canada, which would come to absorb many of these elements. The collapse of the Reciprocity Treaty with the United States in 1865 meant that the Canadian colonies no longer benefitted from free trade in a number of staples products (Dilley, 2012; Davis \& Gallman, 2001). Teetering on the brink of bankruptcy due to fraud, financial mismanagement, and railway speculation (Myers, 1914/1972), the Province of Canada would attempt to extend their credit on the London markets via a union with the similarly indebted Maritime colonies. ${ }^{51}$ Although they were initially dismissive of the idea, the Confederation of the colonies would come in 1867 after the similarly indebted provinces of Nova Scotia and New Brunswick were blocked from their

own financing by British investors, leaving them with no choice but to amalgamate if they wanted to receive more loans (Naylor, 1975/1997, pp. 30-31).

51 Van Houten (1991) provides more detail: "By 1867, both Canada and the provinces of New Brunswick and Nova Scotia as well as a larger number of municipalities were deeply in debt at a time when the railway companies they had lent or given money to were either on the verge of bankruptcy or had actually gone bankrupt. These companies demanded even more financial support. In all \$145,795,853 were spent in Canada on the construction of just over 3,000 kilometres of rail. Nova Scotia and New Brunswick together spent $\$ 8.9$ million on 437 kilometres of rail. On the eve of Confederation, Canada, Nova Scotia and New Brunswick had a total net debt of \$96.2 million, \$50.2 million of which were the result of investments in and loans and other financial commitments to the railways. The Province of Canada had an additional \$18.7 million in debt because of canal construction. In short, three-quarters of the debt was incurred for transportation. In 1866, the service of this debt absorbed $21 \%, 28 \%$ and $30 \%$ of the revenues of Nova Scotia, New Brunswick and Canada respectively" (p. 49). 
Confederation was a reflection of the more general process of so-called nationbuilding in the 19th century, to which the earlier Act of Union was a part. ${ }^{52}$ I say socalled because nation-building ultimately meant the creation and consolidation of a coherent domestic market within a certain territory. ${ }^{53}$ This process involved "the abolition of 'internal' tariffs, tolls, customs duties, and the destruction of precapitalist property relations, among other barriers to a 'regional' free-trade system" (Teeple, 2000, p. 156). In Canada, we can see this in respect to the 1854 abolition of the seigniorial system in the Province of Canada (although the system continued on for a period of time afterwards) and the Rupert's Land Act of 1868, which formally transferred the territory and rights possessed by the Hudson's Bay Company to the Dominion of Canada (Myers, 1914/1972). Nation-building also involved the creation of a single legal jurisdiction, a corresponding political system, and often, a common national identity, although this has long been problematic in Canada for a number of reasons that are better explained elsewhere (Bliss, 2006; Lipset, 1990; Raney, 2009; Rao, 2010; Resnick, 2005). During this period, once an integral market over a certain territory had been created (i.e., the

52 This is not to suggest that there were not practical reasons for Confederation- - there were. Confederation solved three immediate problems for the colonial ruling classes: (1) it expanded the taxation base by pooling together provincial tax revenue, thus enabling the federal state to provide more funds to private railway companies; (2) it removed inter-provincial trade barriers, thus providing at least some remedy for those markets lost as a result of the abrogation of Reciprocity; and (3) it provided a slight measure of protection against the rising power of the U.S. That said, my purpose here is to highlight that their solution to these problems - the creation of a territorially-defined nation-state - followed a similar world-historical pattern to that of other capitalist countries. It is in this sense that we can understand this period as the making of 'national' capital.

53 As McNally (1981) notes: "Every national capitalist class is concerned . . . to protect and expand that section of the world market which it is privileged to treat as its national market. As a result, the consolidation of capitalist nation states is bound up intimately with the extension of the home market. As Marx points out in his discussion of primitive accumulation, the use of state power is a central feature of the transition to the capitalist mode of production. State power, 'the concentrated and organized force of society,' is the 'midwife' of the birth of the new society. Political force, expressed in the form of state power, 'is itself an economic power.' This is especially clear in the case of Canadian Confederation" (p. 54). 
nation-state) it became an economic necessity to secure these borders and expand them to include other territories; especially so if those territories were still defined by precapitalist relations. These various processes formed the substance of colonialism and imperialism during this so-called age of empires (Hobsbawm, 1989). Since Canada itself was a colony (or rather, a series of British and French colonies) its existence was necessarily part of this outward expansion; however, a sort of internal imperialism of the West can also be seen during the period of the National Policy, in addition to the expansion of Canadian corporations to English and French colonies in the Caribbean, a process which ultimately relied on the extension of the rights of private property to those territories under the protection of their colonial masters. I discuss both in more detail a little later on.

In respect to the chartered banks more specifically, Confederation continued the centralization of TAR started in 1841 by requiring all existing banks to be chartered (a process undertaken to protect British shareholders, which I discuss below) and by opening up the territory on which they were legally allowed to operate; in this sense, Confederation represents the beginning of the creation of what would later become a national system of property relations. By virtue of the strength of the chartered banks at the time of Confederation, their dominant role in the colonial economy, and their ownership and control by the respective ruling classes of the former colonies, the British North America Act gave the federal government exclusive authority over all matters 
pertaining to currency and banking. ${ }^{54}$ The task of integrating the various colonial currency and banking regimes was initially shunted aside, however, "by the demands of political nation-building" (McDowall, 1993, p. 27). A temporary Act set to expire in 1870 was rushed through Parliament making the existing provincial charters into Dominion charters which immediately gave all the banks the legal right to operate in any part of the new territory that now constituted the Dominion of Canada; similarly, in 1868, the earlier provincial notes put into circulation were transformed into Dominion notes, indicating that the government was likely to introduce a form of national currency at some point. The Maritime banks also became subject to the same taxation regime of the more dominant central provinces: "to the tax of $1 \%$, upon excess of their average circulation, above the average weekly amount of coin and bullion kept in their vaults" (Breckenridge, 1894, p. 219). As Manitoba, British Columbia, and Prince Edward Island joined the federation, "the scope of the Dominion Bank Act was extended to these territories, and such banks as existed came under it" (Curtiss, 1939, p. 155). It is in this sense that Breckenridge (1894) notes that in respect to banking, "the creation of the Confederation and the establishment of a united Parliament marked the close of one period of Canadian history" (p. 224). From that point on, the assemblage of TAR that formed the basis of the banking business in Canada would become increasingly national despite the extent and continuation of their foreign, mercantile dealings.

54 McDowall (1993) notes that at the time of Confederation "there was no doubt in the minds of Canadians that the scattered banks of their new Dominion were the engine of financial growth in their nascent economy" (p. 27). This is backed up by Neufeld (1972) who notes that the banks "accounted for three quarters of financial intermediary assets; they handled the foreign exchange business; and their stock was by far the most important security traded on the embryonic stock exchanges" (p. 88). 
Confederation initially divided Halifax's mercantile elite, with some seeing "danger in the scheme, an abandonment of the colony's oceanic heritage" (McDowall, 1993, p. 14). Jeremiah Northup and Thomas Kinnear of the Merchants Bank, for instance, originally joined with anti-Confederation Joseph Howe in calling the move a "reckless gamble" (p. 28), and they affixed "their signatures to anti-union petitions that were sent to London" (p. 15). Their fear-which was quickly borne out—was that Confederation would allow the more powerful central banks, led by the Bank of Montreal with assets of $\$ 6$ million, to enter their territory with a hungry eye; by contrast, the largest Halifax bank was the Bank of Nova Scotia with assets of only $\$ 560,000$. Other directors of the Merchants' were not so sure that Confederation was an altogether bad thing, considering Nova Scotia's economic status. The fisheries failed in 1867 and 1868 and trade with the West Indies was drying up; in combination with the abrogation of Reciprocity in 1865 , the Merchants own publications note that the Halifax had become deprived "of a paying trade in many commodities" (Royal Bank of Canada, 1920, p. 11). It was also clear to many of the Merchants' directors that Nova Scotia's mercantile economy was at odds with the nature of the coal, steel, and railway industries; they thus saw Confederation as a means of providing protected banking opportunities in the West. Despite knowing that Confederation would inevitably bring the more powerful Montreal banks to Nova Scotia, the directors of the Merchants made their peace with it.

With the temporary banking legislation set to expire in 1870, Halifax's merchant elite knew that a federal charter was likely "the minimum price of admission into the new world of Canadian banking" (McDowall, 1993, p. 28). Without one, banks would not be 
permitted to expand nationally; getting one was thus necessary to compete against the existing chartered banks, which could legally operate in any part of the new Dominion's territory. Furthermore, as Breckenridge (1894) notes, without the protection of limited liability, it would be impossible for the private banks to secure the capital necessary to expand their operations (p. 361). Anticipating these changes, the directors of the Merchants applied for and received a federal charter; on June 22nd, 1869, an Act incorporating the Merchants Bank of Halifax (so named to avoid confusion with the already existing Merchants Bank of Canada) received royal assent. With an authorized capital of $\$ 1,000,000$, the "competent though not very wealthy institution" (McDowall, 1993, p. 24) was legally transformed into a national corporation. This would be the first step on the way to making the Merchants Bank a form of national capital.

Next on the agenda was the creation of a standardized system of national banking via the Bank Act. The Act would function to standardize the rights of the chartered banks at the national level (essentially acting as their shared charter) and to protect them from both internal and external threats by regulating their competition. ${ }^{55}$ The process was not without conflict, however, as the more powerful Bank of Montreal took the opportunity to suggest that a reorganization of banking was needed to better suit the requirements of a rapidly changing Canadian economy. Their plan was to reorganize the system into three tiers of banks. The first would naturally consist of the Bank of Montreal, which would become the government's bank along the lines of the Bank of England; the second would

55 As Baum (1974) notes: "With purpose, Canada through its federal government caused financial control to reside in the banking industry, which is subject to exclusive federal jurisdiction. Indeed, a bank's charter is the Bank Act" (p. 5). 
consist of the chartered banks which would serve the more general interests of commerce; and the third would consist of small, local, unit banks similar to the United States model, which would look after farming and regional manufacturing interests. The scheme would also involve stripping the banks of their right to issue their own notes and creating a national currency issued by all the banks on the condition that they purchased government debt.

In actual fact, the Montreal's suggestion was a reflection of their own needs: their profits in the foreign exchange markets had declined significantly; corporate debentures were growing as a portion of collateral against their loans; and they had increased their involvement with the ailing Grand Trunk Railway. As McDowall (1993) notes, had the plan been successful, it would have relegated all but the Bank of Montreal "to the status of local currency-dispensers" (p. 29). As a result, the other chartered banks "acted in virtual unanimity to condemn the proposal" (p. 29). To quell the discord, the finance minister simply got all the banks together and asked them what they wanted in the Act. The approach was described by George Hague, general manager of the Bank of Toronto, as "a joint committee of Parliament and banks" (as cited in Naylor, 1975/1997, p. 74). Free to craft their own regulations, the first Bank Act (and all subsequent) represented a compromise between the Montreal, Toronto, and Maritime banks that more or less reestablished the pre-Confederation order of things. The Bank of Montreal would formally lose its position as the government's bank and no provision was made for local unit banks. The federal government would continue to issue one- and two-dollar notes, with the rest issued by the chartered banks, secured by a cash reserve of one-third 
Dominion notes. As Helleiner (2003) notes: "the government would have preferred to monopolize the whole note issue, but encountered enormous opposition from private banks" (p. 94). ${ }^{56}$

Once completed, the Act gave the chartered banks the right "to take deposits and to deal in, discount, and lend money on commercial paper, stocks, bonds, and debentures of municipal and other corporations, and on federal, provincial, British or foreign public securities" (Royal Bank of Canada, 1953, p. 2). The Act also forbade them from dealing in goods, wares and merchandise, or engaging in any trade or business (Galbraith, 1970, p. 16). While the Act did permit the banks to "engage in and carry on such business generally as appertains to the business of banking" (p. 16) it did not clearly specify what this business might be. The banks have since interpreted this to mean that they should not have a controlling interest in any other corporation (contrary to the concept of finance capital). Like the earlier colonial charters, the Act was set to be reviewed every 10 years to allow for modification and "shifts in economic opportunity" (McDowall, 1993, p. 30).

While these rights mainly dealt with the practicalities of banking - in other words, what the banks were and were not allowed to do-their ultimate effect was to give the chartered banks the legal right to expand over the entirety of the new Dominion's territory; in this sense, we can understand them as a crucial part of making a national market for banking. As Lower (1945) notes, this "extension of financial control was

56 Naylor (1975/1997) explains the basis of the conflict: "Essentially what was involved in the debate over note issue power was a choice between using domestic funds for staple movements or for the construction of infrastructure, and the banks preferred to keep up the flow into staples and have the government rely on imports of portfolio capital from Britain to build the railroads and canals that were necessary for staple exports to Britain" (p. 68). 
marked by the action of the chartered banks of the central region, which rushed to establish branches everywhere, without much competition from the outlying banks" (p. 347). As the Bank of Montreal moved in to the Maritimes, the Merchants Bank of Halifax was forced to adopt a two-part strategy to survive. The first involved building up their commercial accounts in Halifax, which included firms related to their directors' other business activities (of which there were many) such as T. \& E. Kenny \& Co. and S. Cunard \& Co. The second part of the strategy involved outward expansion. Moving "along the arteries of trade that bound innumerable Nova Scotia towns to their metropolis" (McDowall, 1993, p. 34), the Merchants opened branches in Pictou, Antigonish, Bridgewater, Lunenburg, Truro, Wemout, and Sydney, with many of them being merely "formalizations of old trading relationships" (p. 38). From 1871 to 1886 , the Merchants would establish a total of 25 branches and sub-agencies in Nova Scotia, New Brunswick, and Prince Edward Island, including correspondence arrangements with banks in London and New York. They would also move swiftly to areas under common British rule, such as the West Indies. ${ }^{57}$ Their quick expansion is the clearest explanation as to why they are Canada's largest bank today. To put the scale of this expansion in context, the Bank of Nova Scotia (today, Scotiabank) opened only 15 branches over the same period. In this sense, the Bank Act provided the chartered banks with the capability

57 As Baum (1974) notes: "In 1871 in the new nation of Canada, banks as the dominant financial institution were competing among themselves for position, for areas each could control. It was not unexpected for the maritime banks, that is, the Bank of Nova Scotia and the Royal Bank of Canada, to move with significant force into the West Indies" (p. 18). Baum explains the strategy: "it must be said that trade merely provided an opportunity for the maritime banks to occupy an area not taken by the then well-established central Canadian banks. After confederation in 1867, the maritime banks had to find a place for themselves; they were at a competitive disadvantage with the more centrally located banks. Thus it was that the maritime banks had to seek out opportunities that were marginal to their central competitors" (p. 19). 
(if they chose to use it) to expand into the new regions opened up by Confederation-a fact we will see in regards to the Merchants after the National Policy and the construction of the Canadian Pacific Railway (CPR). As McDowall (1993) notes: "The Merchants' ability to pay its dividend without interruption throughout the years 1869 to 1887 suggests that, despite the uneasiness induced by its steady expansion, growth brought an element of protection from the economic woes of the [Maritimes]" (p. 41). The Bank Act thus provided the chartered banks with the capability to grow and expand; it was a necessary part of the construction of national capital.

\subsection{The National Policy}

The next significant shift in TAR in respect to banking was the National Policy, which was ultimately a means of extending the Dominion's territory and laying down the foundations for national economic activity. As Teeple (2000) notes, this is why "the construction of roads and canals and later railways and the telegraph became synonymous with nation-building; it was but the building of the infrastructure for a territorially defined regime of accumulation" (p. 162). The spirit of the age was thus: "build a new state, and BUILD! Build the state, shove out its boundaries as far as possible, build railways, build industries and cities!" (Lower, 1958, pp. 25-26). First introduced by Sir John A. Macdonald's Conservative Party in 1876 and put into action in 1879, the Policy consisted of three parts: (1) the building of a transcontinental railway (the CPR); (2) a strong immigration policy to fill out the West; and (3) higher tariffs and patents, a key 
protection of property rights. ${ }^{58}$ Duties on manufactured goods, for instance, were raised from $17.5 \%$ to 30,35 , and in some cases $45 \%$, with textiles, iron, and steel especially favoured (Beaulieu \& Cherniwichan, 2014, p. 150). As Lower (1945) notes, the Policy simply took the basic sketch of the Canadian nation-state designed during Confederation and "put up a fiscal fence around it" (p. 373).

The Policy itself was the result of a variety of factors, not least of which was British Columbia's entry into Confederation in 1871 on the promise of a transcontinental railway and the more general state of the global political economy in the 1870s. With foreign demands on timber increasing as a result of the global railway boom, the Dominion's economy had been doing rather well, and "the banks, it may be expected, shared in this expansion" (Breckenridge, 1894, p. 204). A world depression in the late 1870s would reverse this trend, however, with economic growth falling to less than $5 \%$ per year and imports growing more than $13 \%$ (p. 218). ${ }^{59}$ This disparity in trade was a significant problem for Canada. While Britain could settle their balance of payments by extending new loans to the colonies, the Canadian government had no such means at their

58 Sir John A. Macdonald described the need for the National Policy as such: "We have no manufacturers here. We have no work people; our work-people have gone off to the United States .... These Canadian artisans are adding to the strength, to the power of a foreign nation instead of adding to our own. Our work-people in this country on the other hand are suffering from want of employment. If these men cannot find an opportunity in their own country to develop the skill and genius with which God has gifted them, they will go to the country where their abilities can be employed, as they have gone from Canada to the United States ... . If Canada had a judicious system of taxation they would be toiling and doing well in their own country" (Naylor, 1975/1997, p. 7).

59 Breckenridge (1894) provides some context: "Building operations in Canada and the United States, and the rapid additions to the railway system in either country, raised the price of lumber. With the increase of other foreign demands, they stimulated the timber trade, and caused abnormal inflation. The speculation extended to timbered lands and timber limits. All sorts of manufacture were pushed to the bounds, which, in 1875, were acknowledged to have been unreasonable. Municipalities of every grade caught the infection and adopted the pernicious system of granting bonuses to manufacturing companies proposing to establish themselves in the district of the grantors ... The time is best described as one of increased activity in manufacture, transportation and exchange" (p. 204). 
disposal; the result, as Naylor (1975/1997) notes, was the collapse of a number of overextended banks (pp. 118-150). ${ }^{60}$ This reality, along with the government's inability to negotiate another Reciprocity Treaty with the United States, and the rise of protectionism more generally due to Britain's failure to incorporate Germany, Japan, and the United States into a free trade empire (Panitch \& Gindin, 2004, 2012; Sassen, 2006), forced the Canadian government to adopt similar nation-building measures that would ultimately function to extend and strengthen the national political economy, and thus, the country's most powerful corporate actor: the chartered banks. Indeed, as Polanyi (1944/2002) notes, this sort of protectionism "helped to transform competitive markets into monopolistic ones" (p. 227). The specific effect of the National Policy on banking was therefore less to do with the legislation itself, and more to do with the opening up of the territory on which the banks could operate. Where the earlier Bank Act had given the chartered banks the legal right to operate across the entirety of the new Dominion's territory, the National Policy would provide the physical infrastructure (in the form of the railway) to make this a reality. The Policy would thus give the chartered banks the capability to follow the staples trade across those territories that had previously been the

60 Eichengreen (1996/2008) provides a succinct description of the problem at hand for the Canadian government: "In the case of Britain, and to a lesser extent other European creditors, an increase in foreign lending might provoke an offsetting shift in the balance of merchandise trade. Increasingly after 1870 - coincident with the advent of the international gold standard - British lending financed overseas investment spending. Borrowing by Canada or Australia to finance railway construction created a demand for steel rail and locomotives. Borrowing to finance port construction engendered a demand for ships and cranes. The fact that Britain was a leading source of capital goods imports to the countries it lent money to thus helped to stabilize its balance of payments. A decline in the volume of capital flows toward primary-producing regions, in contrast, gave rise to no stabilizing increase in demand for their commodity exports elsewhere in the world. And similarly, a decline in commodity export receipts would render a capital-importing country a less attractive market in which to invest. Financial inflows dried up as doubts arose about the adequacy of export revenues for servicing foreign debts. And as capital inflows dried up, exports suffered from the scarcity of credit. Shocks to the current and capital accounts thus reinforced each other" (pp. 38-39). 
exclusive property of the Hudson's Bay Company. ${ }^{61}$ This internal imperialism would subsequently enable them to attract new portfolio capital from foreign, mainly British, sources.

The Policy also coincided with the decennial revision of the Bank Act, reigniting calls to create a national currency as a means of "discouraging imports, promoting domestic industry, and reducing the country's dependence on foreign loans" (Helleiner, 2003, p. 75). Supporters of the plan would claim that a national currency was needed to guarantee "the full employment of the people and the development of the productive resources of the country" (p. 88). They argued that "the state, rather than private banks, should be the institutions issuing notes in Canada because money was linked to sovereignty" (p. 117). Although their attempt would fail, it represents another stage in the long struggle to transfer the chartered banks' right of note issue to the nation-state for the purpose of building up the national political economy. Unsurprisingly, the chartered banks would also exert "an energetic opposition" (Breckenridge, 1894, p. 290) to calls to remake their charters after the National Banking System of the United States. They would also reject a proposal to establish government inspection of the banks on the basis that it was "far better to rely on the careful organization of the banks, the vigilance of the

61 Pentland (1981) explains the matter clearly: "The National Policy of 1879 was one weapon of Canadian imperialism. Its purpose was not to make Western Canada also a participant in a selfcontained economy; for the West was fully expected to sell its staple product in world markets, as it did, and there appears to have been no regret that the new Canadian structure was made more vulnerable and dependent than its predecessor. The task of the National Policy of 1879 was rather to ensure that unprotected Western wheat was carried by protected Canadian railroads and handled by protected Canadian traders, and that the supplies of the West should come from protected manufacturers, in order that as much as possible of the gains to be made would be drawn to old Canada, and not to Britain or the United States. It was this imperial prospect that brought merchants and railroads suddenly around in the 1870s, so that Eastern Canada spoke with an undivided protectionist voice" (p. 173). 
directors, and the inspection by trained men of its own staff' (p. 291). Once again, the Minister of Finance would simply ask the chartered banks to create their own Bank Act: "some plan mutually advantageous to the government and the banks" (McDowall, 1993, p. 60). The final result was, unsurprisingly, a provision that raised the capital-stock requirements of new banks, thus making it harder for them to form. The Act would also include a provision in which "the assumption by any firm or bank of the title 'bank' without authority under the general banking laws of the Dominion, was made a misdemeanour" (Breckenridge, 1894, p. 293). Later revisions to the 1890 Act would again raise the capital requirements and require all the banks to make their notes redeemable at offices across the entire Dominion, ensuring "that all notes circulated across the whole country without discount" (Helleiner, 2003, p. 126). With the interests of the chartered banks coming together as they grew larger, they also moved to formally establish the Canadian Bankers Association (CBA). ${ }^{62}$ Parliament would eventually grant the CBA the legal right to block new banks from receiving charters, thus allowing the chartered banks to grow relatively unimpeded in the national market.

The cumulative effect of all these policies is reflected in the transformation of the Merchants Bank; in particular, its rapid expansion and growth. While the directors of the

62 Darroch (1992) explains the role of the CBA in creating 'orderly markets': "The same spirit which encouraged industry concentration further encouraged banks to seek complementary rather than direct competitive positions because competition does not promote stability. A stable oligopolistic market structure demanded that different competitors seek differentiated positions in order to avoid direct competition and its inevitable consequence of price competition. The creation of Canadian Bankers' Association in 1891 was a key event in cementing and promoting the maintenance of orderly markets" (p. 154). Naylor (1975/1997) explains the general effect: "after the Canadian Bankers' Association was formalized in 1890, interest rate competition was minimized. Competition thereafter took the wasteful form of proliferation of branches to secure both savings deposits and new clients for loans. It was standard big business behaviour, excess capacity coexisting with a restricted number of units operating behind barriers to the entry of new firms, and refraining from price competition" ( $p$. 96). 
Merchants had initially seen the National Policy as the means by which they could get Maritime sugar and steel to central Canadian markets, reality would be far less kind to Nova Scotia. ${ }^{63}$ The Americans would win the battle of the ports and Montreal would win the battle over the seat of Canadian sugar production. With the Maritimes stuck in a depression in the $1880 \mathrm{~s}$, the Merchants responded by first moving "south to Britain's warmer colonies or to other centres in the Atlantic fishery" (p. 45). To this effect, they negotiated entry into Bermuda in 1882, St. Pierre and Miquelon in 1886, and Cuba in 1889. ${ }^{64}$ They also moved to Montreal in 1887, the metropolis of Canadian banking. Further moves came in 1890 after the collapse of the English merchant bank Baring Brothers, which created suspicions in England as to the "soundness of all foreign investments" (Royal Bank of Canada, 1920, p. 18). With the flow of English capital to Canada temporarily restricted, the Merchants negotiated a correspondent agreement with

63 McDowall (1993) notes that "in the minds of men like Thomas Kenny, the National Policy held the promise of "nationalizing' Halifax" (p. 43).

64 It is important to note that there is a certain amount of contingency in these movements that defies any logic of capital. The Merchants' entry to Bermuda, for instance, was the result of their accountant, David Duncan, being ordered to travel there after getting sick. Within a month, Duncan "had struck a deal with the mayor of Hamilton, Nathaniel Butterfield, to act as the Merchants' agent 'as an experiment' for a year" (McDowall, 1993, p. 163). The event is recorded in the Banks' minutes dated March 30"th 1882: "Mr. Duncan, the Accountant, having been confined in his house through a severe attack of rheumatism, the President being of opinion that his (Mr. D's) health was not fully reestablished, suggested a visit to Bermuda, to which the Board assented. Mr. Duncan was accordingly advised by his physicians to avail himself of the opportunity, as calculated to do him much good, and he was also authorized by the Board in the event of his finding a suitable opening to establish an agency of the bank at Hamilton" (Royal Bank of Canada, 1920, p. 16). Butterfield's son was also sent back to Canada, to learn from the Merchants Bank, but this would end in disaster. After suspecting that Butterfield was using his affiliation with the Merchants to further his own commercial ambitions, his son was sent back to Bermuda in 1886. For the next three years, the Merchants would attempt to maintain their own agency on Front Street, but without the help of local Bermudians to assist in penetrating the local market, the operation failed. After 1890, Bermudian merchants would pass legislation insulating their banks from foreign competition, and, in 1904, the Butterfield's would incorporate their own bank, using the lessons they learned from the Merchants. This experience would lead the Merchants to closely guard future foreign agencies, treating them as an extension of the national branch system. The Butterfield's remain today, one of Bermuda's most powerful families. 
Chase National Bank in New York. This gave them access to foreign exchange and credit facilities, as well as the opportunity to invest their surplus abroad.

The Merchants' rapid growth through the 1890s made them, like all the chartered banks, acutely aware that Canada's economic development was not happening fast enough. Writing on behalf of all the banks, Thomas Fyshe complained in 1895 that, "the population and business of the country are both growing very slowly, so much as to suggest the gravest doubts whether we have been using the best means to make the most of our resources" (as cited in Quigley, 1986, p. 34). The Merchants would respond to this issue in three ways. The first was similar to all the chartered banks, which started to build up a solid portfolio of American railway and utilities bonds (Deneault, 2015, p. 16). Quigley (1986) notes, for instance, that "between 1881 and 1900, the securities held by all Canadian banks increased from $1.6 \%$ of total assets to $9.3 \%$; with $51 \%$ of the latter figure being railway and other corporate securities" (p. 35). The second was to create a trust company that would link them to the larger Bank of Montreal. ${ }^{65}$ The third was to expand the geographical scope of their operations. They would do this by moving further into those areas of the Caribbean under British rule (Hudson, 2010) and by taking advantage of the National Policy to move further west with the opening of the frontier. Branches would be opened in Atlin, Grand Forks, Bennet Lake, Ymir, and Vancouver's East End, as well as in Republic, Washington, "where Montreal mining interests had investments and where the Merchants' saw an opportunity to profit from foreign

65 The directors of the Merchants would form the Eastern Trust Company in 1893. The Merchants would then align with Montreal Trust, created by the Bank of Montreal, which would later link up with Royal Trust, making the circle complete. 
exchange" (McDowall, 1993, p. 69) ${ }^{66}$ Having begun the process of staking their claim to the Canadian West, the Merchants would also move into Ontario in 1899 after purchasing an ailing branch of the Banque Jacques-Cartier in Ottawa. As McDowall (1993) notes, this expansionary strategy would make the Merchants "a national bank" (p. 124).

With a network of branches that now extended from Victoria to Havana, the Merchants' name seemed increasingly anachronistic to its directors. The Merchants Bank of Halifax thus became the Royal Bank of Canada in 1901, a name with "imperial and national pretensions" (Hudson, 2010, p. 37). The president of the Royal, Thomas Kenny, claimed that the change was needed since "the bank's 'changed circumstances' demanded 'a title distinctive and comprehensive"' (as cited in McDowall, 1993, p. 76). The name change was also followed by a head-office move to Montreal in 1906, further cementing their status as a national bank. Their status as a national bank (or national capital, if you like) was the result of the capabilities provided to them by the state; that is, their right to operate throughout the Dominion (as well as through those other protected colonies over which British rights extended), their right to restrict newcomers from impinging on that right, as well as their physical ability by way of the railroads to move across the country. McDowall (1993) makes mention of this when he writes that the Royal's branches often sprung "up at the "end of steel"” (p. 72). These capabilities made it possible for the Royal

66 Lest the reader imagine these as typical, well-built, urban or suburban branches (thus implying some sense of attendant development), it is useful to remember that they were essentially wooden shacks. Letters from staff recall the branch at Bennet Lake as being "so full of cracks you can hear the wind whistling through them" (McDowall, 1993, p. 88). A similar style of branch in Gowganda, Ontario (whose waterfront is now called Banker's Bay) is described by the Globe and Mail (1909): "Away further to the left a big Canadian flag flapped before the door of the 'Royal Bank of Canada's tent. Beside it to the left the log structure of the Canadian Bank of Commerce was beginning to show its stately lines, and, to complete the row, stood a surveyor's log shanty, a contractor's big log camp and a huge tent on the ice just off the shore, labelled 'Baxter's Hotel'” (p. 5). 
to create an extensive branch network that moved capital from areas that saved to areas that borrowed: "surplus capital from savings on which the bank paid 3\% could be transferred to regions hungry for capital and lent for 6 to $7 \%$, not only enhancing profits, but more importantly, building up clientele" (p. 70).

This process was greatly accelerated by a revision to the Bank Act in 1900 that allowed the chartered banks to merge without obtaining a special act from Parliament. ${ }^{67}$ While the Royal was still a relatively small bank at this time, "with only 162 of the nation's 2367 branches" (p. 124) it used the Act's revision to spread out across the country and absorb the existing local and government savings banks. Moving west, the Royal would possess 21 branches in British Columbia and 25 in Ontario, including a branch in every provincial capital by 1908; moving east, they would absorb most of the Maritime banks by 1910 (see Table 1). The takeover of the Union Bank of Halifax, for instance, would add "some $\$ 16,000,000$ ” to the Royal's assets and increase their "capital and reserve to nearly $\$ 13,000,000 "$ (New York Times, 1910, p. 8). The New York Times (1910) would note that this merger was in line with a more general "tendency toward consolidation among Canadian banks" (p. 8). The takeover of the government savings banks was especially significant because they not only increased the Royal's deposits, and thus, the strength of their lending position, but also redirected the public's savings from bonds (state, municipal, railroad) and public buildings toward commercial

67 As Sweeny (1997) notes: "this opened the floodgates: in the previous quarter century there had only been four mergers, by 1926 there would be a further 27" (p. 326). 
banking. ${ }^{68}$ As McDowall (1993) notes: "more than anything else, mergers vaulted the Royal into the leadership of Canadian banking” (p. 125).

Table 1

Number of Branches, 1909

\begin{tabular}{|lll|}
\hline & Royal Bank of Canada & All Canadian Banks \\
Canada & 113 & 2164 \\
Newfoundland & 1 & 6 \\
New York & 1 & 44 \\
Caribbean & 13 & \\
\hline Total & $\mathbf{1 2 8}$ & $\mathbf{2 2 1 4}$ \\
\hline
\end{tabular}

Note. Reprinted from Quick to the Frontier: Canada's Royal Bank, by Duncan McDowall, 1993.

The Royal's domination of the national market was not without struggle, however, and it often required exerting federal authority over provincial governments. As the regional character of banking disappeared, it was sometimes unclear which level of the state (municipal, provincial, federal) had rights over certain aspects of the chartered banks' activities. An example of this can be seen in 1909 when a guarantee was given to the Alberta and Great Waterways railway by the Alberta government. When the $\$ 7.4$ million in bonds were floated in London, the Royal, along with two other banks, the Union Bank of Canada and the Dominion bank, agreed to create accounts in New York for the proceeds (McDowall, 1993, p. 208). After the project was derailed by scandal, the Alberta government demanded that the Royal divert the funds back into the province's general revenue. When the Royal refused, the Alberta government took them to court.

68 When asked in the House of Commons in 1913 whether his savings department differs from the government savings banks as a whole, Sir Edmund Walker, president of the Canadian Bank of Commerce replied: "Oh yes, we take the savings money and use it in commercial banking" (as cited in Naylor, 1975/1997, p. 93). 
The New York Times (1910) noted that the sum was "the largest amount ever sought to be recovered in an action in [Alberta]" (p. 11). When the Alberta government won, receiving \$6.5 million in damages, the Royal appealed the decision, taking it all the way to the Judicial Committee of the Privy Council in London. As McDowall (1993) notes, the result could have been a disaster for the Royal, as any hint that their capital "was subject to the whims of provincial governments could spoil investor confidence" (p. 208). In 1913, the Royal's solicitor, future Prime Minister and Royal director, R.B. Bennett, argued that Alberta had acted ultra vires when they denied bondholders their civil rights as set out in Section 91 of the British North America Act. The Edmonton Bulletin reacted to the decision by noting that it was "a particularly flagrant case of protection of private or corporate interests against public right. The province is being ground between the upper and nether millstone of the Privy Council and the Royal Bank" (Hanson et al., 2003, p. 41). For the chartered banks, however, the ruling meant that the power of the Canadian state was now their "ultimate guarantee in the face of a regional challenge" (p. 208).

\subsection{The Finance Act}

While Confederation, the Bank Act, and the National Policy functioned as capabilities enabling the chartered banks to grow and expand, their growth was fraught with the contradictions of capital accumulation; that is, the self-destructive tendency for capital to eat away at the very social conditions that sustain it. The government would thus be forced to transfer some of the rights of the chartered banks to the nation-state in 
exchange for a variety of protective services that would enable them to continue their expansion. ${ }^{69}$ The first was the 1914 Finance Act and the second was the 1934 Bank of Canada Act. Both would put the expansion of credit in the hands of the national government, as opposed to the banks; in doing so they would protect the chartered banks from the contradictions of their own accumulation activities by forcing them to reorient their lending toward the development of the national political economy. In this sense, we can understood these two Acts as a reflection of a more general 'nationalization' of state capabilities that would ultimately reach their apex with the emergence of the welfare state.

The origins of both Acts can be found in the growing power of the chartered banks and their effect on national economic development. The annual fall sale of crops in the West (remember, that at this time, Canada was mainly a country of farmers) brought with it a demand for ready cash; but since the banks could only circulate notes to the extent of their paid-up capital, there was always a cash drought each fall which "tended to choke national development" (McDowall, 1993, p. 74). After consultation with the CBA, the finance minister revised the Bank Act in 1908 to allow the chartered banks to increase their "note circulation during 'crop-moving' season to $115 \%$ of their capital base" (p. 74). This revision was significant because for the first time it gave the federal government a direct mechanism to affect the volume of credit. The 1913 Bank Act revision would

69 As Polanyi (1944/2002) writes about modern central banking, noting: "Modern central banking, in effect, was essentially a device developed for the purpose of offering protection without which the market would have destroyed its own children, the business enterprises of all kinds" (p. 201). Fred Block and Margaret Somers (2014) have expanded upon this idea more recently, noting that "the growth and elaboration of central banking created a variety of means by which the impact of international forces was lessened" (p. 55). 
expand this mechanism by creating a Central Gold Reserve that would allow the banks to obtain excess circulation upon the deposit of gold or Dominion notes; in other words, a sort of rudimentary central bank, a taste of what was to come.

The 1913 revision also required the chartered banks to secure ministerial approval for mergers before they were approved by their shareholders. By requiring the banks to seek ministerial approval before finalizing mergers, the finance minister was "put in a better position to ensure that the public interest was served by a proposed merger" ( $\mathrm{p}$. 144). As McDowall (1993) notes, the revision was a clear response "to the public mood of reform" (p. 144), as the growing size and power of the chartered banks had, by this time, become a fetter on the economic development of the West. ${ }^{70}$ The chartered banks would defend their size on the basis that it was a requirement of the increasing scale of economic development. The Royal's president, Herbert Holt, would tell shareholders in 1912 that when Canada was "a country of small affairs, small banks sufficed, but that we must have banks to handle the large operations of the present day" (p. 124). A similar sentiment was expressed by Nathaniel Curry, a Nova Scotia industrialist, who wrote to

70 Naylor (1975/1997) provides some historical context: “As early as 1883, Manitoba businessmen complained of a financial squeeze imposed upon them at the instigation of central Canadian financial magnates. This agitation contributed a great deal to the creation of the Commercial Bank of Manitoba in 1885 to service the local community. By 1907, agitation was widespread in B.C. for a system of provincial banks. The existing banks were accused of draining surplus funds from the province for the benefit of eastern enterprise while B.C. firms were starved for credit. The Bank of Vancouver was established in 1911 in response to these local needs. In Alberta, the farmers' organizations long advocated a Provincial Bank of Issue and a system of provincially chartered local unit banks on the American state bank model. In Saskatchewan, a Royal Commission investigating agricultural credit called for increased control of financial institutions within the province and denounced the chartered banks, who conspicuously lacked directors from the western provinces. The little Weyburn Security Bank was held up as a model before the 1913 Committee on Banking. And a western member of the House of Commons that year denounced the Bank Act for facilitating the creation of a 'money trust' by encouraging mergers and inhibiting new entrants. What was needed, he claimed, was 'more banks, and a scattered management of banks, rather than concentration.' These sentiments were repeated by the Grain Growers Association" (pp. 101-102). Further details are given by McDowall (1993) from the Royal's perspective (p. 141). 
the finance minister in 1913 to argue that the current scale of economic development made it "absolutely necessary to have large banks" (p. 452). Later, in 1919, the general manager of the Bank of Nova Scotia would remind the same finance minister that "only large and strong banks can expand" (p. 124).

While the outbreak of the First World War in 1914 would put a slight halt on the chartered banks' expansion, the Finance Act would allow it to continue apace by putting the expansion of credit in the hands of the Canadian government. The start of this process began with the end of the Laurier boom and the start of the First World War. ${ }^{71}$ After investment from Europe dampened as a result of the war, panicky savers began to raid their deposits to purchase gold. The significance of this event is explained by McDowall (1993):

The backbone of the Canadian banking system was the gold standard. The ultimate guarantee for anyone holding a Canadian banknote was that it was backed by gold or gold in the form of Dominion notes. While this ensured confidence and stability in the national currency, the reserves backing a bank's circulation were essentially non-earning and tended to crimp a bank's ability to expand credit in a buoyant economy. When Ottawa partially alleviated this strain by creating the Central Gold Reserve Pease [the Royal's general manager] was strongly in favour of it as a means of expanding the Royal's credit. Extra

71 McDowall (1993) describes the situation: "In the spring of 1913 this felicitous relationship of eastern banker and western grower suddenly became strained. The Laurier boom finally faltered in the face of a sharp slump in the North Atlantic trading economies; grain demand slackened, and credit contracted in London. Drought accelerated the collapse: wheat yield per acre in 1914 was only 74 percent of its 1913 level. The downturn soon reverberated throughout the banking industry" (p. 210). 
circulation, made possible by the deposit of gold or Dominion notes in the central reserve, gave the bank added reach in the national economy (p. 151).

The outbreak of war, however, unsettled this system as Canadians began to hoard gold as a financial hedge against disruptions to the market. The federal government responded by suspending the gold standard in August of 1914, instead letting the chartered banks create credit up to $15 \%$ of their paid-up capital by borrowing Dominion notes and securing the advances with collateral of high-quality securities, such as municipal, utility, and railway bonds. Furthermore, the banks were allowed "'excess circulation' beyond the traditional crop-moving period of the year" (p. 212). While the banks were now backed by the confidence of the federal government and their solvency ensured, the agreement was also illegal, running counter to the Bank Act; in response, Prime Minister Borden called a cabinet meeting to ratify the changes: "when Parliament convened later in August, 'An Act to Conserve the Commercial and Financial Interests of Canada' - the Finance Actmade the whole exercise legal"' (p. 212).

The Finance Act signalled an important shift in the relationship between the chartered banks and the Canadian nation-state. Prior to the First World War, the chartered banks were only loosely constrained by regulatory legislation and usury laws, with the CBA functioning "as a legally sanctioned cartel, fixing interest rates, delineating spheres of influence, and regulating entry into the business" (Naylor, 1985, p. 65). With the introduction of the Finance Act, however, the nation-state not only became the lender of last resort, but the suspension of the convertibility of Dominion notes into gold meant that the federal government could "resort to the printing press to finance part of Canada's 
war effort" (p. 67); as such, it now had a mechanism to alter "the level of bank cash and therefore the credit base of the chartered banking system without reference to the net movement of monetary gold" (p. 68). The federal government was forced to use this tool as a result of the failure of the British to finance the cost of Canada's military operations overseas. While the British government initially promised to finance this cost through a \$60 million advance from the treasury, by March 1915 their generosity was exhausted, forcing Ottawa to resort to the printing press and to impose new user taxes "on financial, railway, and telegraph companies" (McDowall, 1993, p. 213). As McDowall (1993) notes, the significance of this 'nationalization' of authority is that it "put the power of expanding credit in the hands of the government, not private bankers" (p. 153). Similarly, the Treasury Board would acquire the power to fix interest rates, a power that was previously under the control of the CBA within the limits set by the usury laws. As Naylor (1985) accurately notes: "the change was symbolic of the political forces at work during the war and continuing just after it" (p. 91). Authority that had previously been exercised by a private sector business association by virtue of the delegation of power to it by the federal government was now "ceded to a politically appointed, civil service organization" (p. 91).

Most of the chartered banks had become accustomed to this new relationship with the state by the end of the war. The general manager of the Royal, Edson Pease, felt differently, however; elected to the head of the CBA in 1916, Pease argued that it was "not a good principle for the government to engage permanently in the banking business" (as cited in McDowall, 1993, p. 212). He suggested instead that it would be more prudent 
to have an independent bank of rediscount similar to the United States Federal Reserve; in other words, an independent central bank:

If we had a bank of rediscount patterned somewhat after the Federal Reserve Bank in the United States, it would render legitimately available millions of assets in the form of high grade commercial paper, now lying dormant in the portfolios of the banks, and thereby greatly increase our financial resources (p. 154).

The suggestion was rejected by the Bank of Montreal which, generally speaking, rejected any policy that threatened its position as the government's banker. Having overseen the federal government's financial affairs in London since Confederation, the Bank of Montreal still managed the government's loans and departmental accounts. Unsure as whether to divide the government's accounts among all the chartered banks, or whether to allow the Bank of Montreal to continue as the government bank, the finance minister would simply extend the Finance Act until the normally scheduled 1923 revision; as McDowall (1993) notes: "the status quo prevailed" (p. 156).

As a means to protect Canada's financial system, and thus, the chartered banks, the Finance Act enabled the Royal to continue expanding. Although they were already well-established in the those territories of the Caribbean over which British property rights extended, the post-war period would see a massive expansion of both their foreign 
and domestic banking business. ${ }^{72}$ In part, this was due to the U.S. Federal Reserve Act of 1913, which freed the American banks from their territorial confines. Where the Royal previously played an important role in mediating capital flows between New York and London through self-made tax havens in the those areas of the Caribbean under British rule, they were now forced to adapt to international competition from American banks rushing abroad. This inevitably meant that they would have to expand to survive; from 1918 to 1925 they doubled their number of international branches, becoming Canada's leading international bank with 121 branches in 28 countries (see Table 2). They also purchased a fifteen-story office building on the northeast corner of William and Cedar street for their New York agency. As noted in the New York Times (1919) the purchase was the "result of the recent expansion of banking activity in New York," and was "in line with the tendency of banks to buy property for permanent occupancy, because of the rapidly narrowing area in the financial section available for their use" (p. 6).

This expansion continued at home as well, however. Indeed, as McDowall (1993) notes: “the Royal's pre-eminence as Canada's leading international banker was in large measure rooted in its ability to muster sufficient manpower at home to realize its ambitions abroad” (pp. 158-160). As part of Mackenzie King's push to break the Bank of Montreal's monopoly on government banking, the Royal gained a number of government

72 Hudson (2010) provides some detail on their Caribbean expansion: "substituting political ties for economic tethers, the Royal Bank embarked on a major push in the Anglophone Caribbean through a strategy that combined mergers and acquisitions of existing institutions with branch expansion. In some case, it gained near-total control of the commercial financing of the colonies in which it set up shop. In 1910, it absorbed the Union Bank of Halifax, which in addition to its thirty branches in the Canadian Maritimes had agencies in Trinidad and Puerto Rico that largely served the financial needs of the Canadian utility and rail companies operating in the two islands. The Bank of British Honduras in Belize, which financed Belize's hide and mahogany exports, was taken over in 1912 and soon thereafter, according to its manager F.R. Beattie, it was 'conduct[ing] the entire banking business of the colony"' (p. 39). 
accounts, such as Canada National Telegraph. They would also continue to expand through government-assisted mergers with failed banks (see Table 4). ${ }^{73}$ The spectacular failure of the Home Bank of Canada in 1923, however, would force the federal government to revise the Bank Act to include an Inspector General of Banks "to police the system by making an annual inspection of each chartered bank" (McDowall, 1993, p. 148). In an attempt to influence this shift in authority, the Royal lent the government one of their own, Charles S. Tomkins. With “bankers' fears of political interference” (p. 232) minimized, the Royal's national expansion could continue apace: branches were opened in Quebec mining towns, the grain port of Churchill, Manitoba, and Fort St. John in the B.C. interior. By 1929, the Royal would possess 44 branches in Montreal, 37 in Toronto, and 20 in Vancouver (see Table 2). ${ }^{74}$ They were not only Canada's largest bank, but a "national institution" (McDowall, 1993, p. 161), a point reflected in the addition of the

73 For example, the Royal took over the ailing Union Bank of Canada in 1925: "Liberal Finance Minister James Robb obligingly approved the merger on May 22. Few protested" (McDowall, 1993, pp. 157158). Morck et al. (2007) provide more details as to how the conditions of the Great Depression led to the rise of widely-held firm: "Canada's banking system underwent a profound crisis in the 1920s and another in the 1930s. World War I inflation ushered in several years of deflation, bankruptcies, and bank failures. Much merger activity in the early and mid 1920s involves government orchestrated consolidations of healthy banks with distressed ones in the early 1920s. By 1928, Canada had only ten chartered banks, down from thirty in 1910. The last narrowly held family bank, Molson's Bank, was taken over by the Bank of Montréal. The downturn wiped out several of the professional managers running former Aitkin group firms and several old family fortunes, contributing to the decline in importance of family groups" (p. 112).

74 Furthermore, as Van Houten (1991) notes: "In 1927, the Bank of Montreal held 25.98\% of the resources of all banks. The Royal Bank, the Canadian Bank of Commerce and the Bank of Nova Scotia accounted for $26.09 \%, 16.54 \%$ and a little more than $8 \%$ respectively. Together these four banks accounted for $77 \%$ of banking assets" (p. 71). 
provincial crests of all the provinces to their new building on St. James Street (see Table 3). ${ }^{75}$

Table 2

The Royal's Growing Branch Network in 1918

\begin{tabular}{|ll|}
\hline Location & No. of Branches \\
Alberta & 34 \\
British Columbia & 40 \\
Manitoba & 29 \\
New Brunswick & 19 \\
Newfoundland & 6 \\
Nova Scotia & 54 \\
Ontario & 152 \\
Prince Edward Island & 6 \\
Quebec & 51 \\
Saskatchewan & 97 \\
Yukon and Northwest Territories & 0 \\
Total Canadian & 488 \\
International & 60 \\
\hline Total & $\mathbf{5 4 8}$ \\
\hline
\end{tabular}

Note. Reprinted from Canadian Banks and Global Competitiveness, by James L. Darroch, 1994.

It is important to note, however, that much of their expansion during this period rested on American direct investment. ${ }^{76}$ Having already taken over most of the country's smaller banks, the Royal's own publications note that by the 1920s there "were now no

75 "When the directors commissioned the New York architects York and Sawyer to design a new head office - taller than the Bank of Montreal's - on St. James Street in 1926, they instructed them to decorate the gilded ceiling of the main banking hall with the provincial crests of all the provinces, not just the coats of arms of Halifax and Montreal" (McDowall, 1993, p. 162).

76 From 1900 to 1910 the amount of American investment entering Canada tripled annually from $\$ 168$ million to $\$ 487$ before doubling again five years later (Van Houten, 1991, p. 72 ). 
cities but a few towns in Canada in which the bank was not represented" (Royal Bank of Canada, 1920, p. 25). As such, the Royal set up foreign trade departments in Montreal and New York, with the New York office overseeing the newly created 'New Business Department,' which was meant to "get in touch with American firms established or proposing to establish branches outside of the United States" (Quigley, 1986, p. 36). The Royal's plan was less about American imperialism (as is commonly claimed) and more to do with a combination of factors such as Canada's low population and industrial capacity, its geographical proximity to the United States, the general scale of production, technological change, and the passing of the American frontier. ${ }^{77}$ It was also a reflection of the resources and personnel of the chartered banks, who were now finally large and specialized enough to design and operationalize their 'industrialization by solicitation' strategy to develop Canada's economy. ${ }^{78}$ Their main hope was that trade would result from the establishment of American branch plants, which would allow them to "take

77 As Clement (1978) notes, one can simply treat this decision as a result of capitalist logic: "alone, national financial capital is inherently weak. It requires secure long-term capital outlets. Rather than risk supporting indigenous Canadian industrialists who were less stable, and given the inviting option of U.S. companies, financial capitalists in Canada frequently exercised their option and supported the larger and more secure companies from the United States" (p. 324). This point is similarly made by Van Houten (1991): "Enjoying special functions and rights under the Bank Act, the chartered banks found it more profitable and, from the collective capitalist standpoint, less controversial to restrict themselves to the role of financiers than to become directly involved in industrial ventures. The Royal Commission on Corporate Concentration noted that banks had 'a built-in stabilizer which produces profits in good times or bad while corporations do not.' During recessions, the banks' borrowing and lending rates tended to fall but the latter did not fall as much as the former so that the spread between the two tended to widen. In other words, more profit was made on less volume. During booms, increased volume allowed the banks to narrow the spread, enabling them to maintain their return. The relative stability of bank profits was an incentive to refrain from direct investment in the riskier industrial ventures" (p. 97).

78 Naylor (1985) provides more details: "as early as 1920 the Minister of Finance, Sir Thomas White, had recommenced the old game of publicly inviting American capital to partake of Canada's corporate fruits. With the foundations already in place in the pre-war boom through joint ventures, licensing arrangements, and cartel agreements, and with a legacy of wartime industrial cooperation to reinforce the ties, American capital responded quickly and favourably to America's new position as dominant world capital exporter by flowing freely into Canada. Mineral development, pulp and paper, automobile, electrical product, and chemical plants were the most favoured sectors" (p. 99). 
advantage of the preferential tariffs applying to Canadian goods entering other British Dominions" (Quigley, 1986, p. 49). Through this strategy, Canada became one of the first modern 'outsourcers' available to American capital. Entering via direct investment in the form of branch-plants to jump the tariff wall, this investment profile defined Canada's industrial and resource sectors for the next 60 years, providing multiple opportunities for the chartered banks to profit (Clement, 1977; Davis \& Gallman, 2001; Naylor, 1975/1997; Panitch \& Gindin, 2012). These U.S. companies paid special attention to Canada "partly because of its proximity but mainly because they wanted to partake in the profit to be made in a country with vast stores of natural wealth and a rapidly expanding market" (Van Houten, 1991, p. 127).

Table 3

Total Assets of Canada's Chartered Banks, 1930

\begin{tabular}{|l|l|}
\hline Bank & Total Assets \\
\hline Royal Bank of Canada & $\$ 962,028,396$ \\
Bank of Montreal & $\$ 896,936,956$ \\
Canadian Bank of Commerce & $\$ 738,827,055$ \\
Bank of Nova Scotia & $\$ 274,533,061$ \\
Banque Canadienne Nationale & $\$ 154,539,269$ \\
Dominion Bank & $\$ 154,181,303$ \\
Imperial Bank of Canada & $\$ 144,414,716$ \\
Bank of Toronto & $\$ 131,508,636$ \\
Banque Provinciale du Canada & $\$ 53,424,058$ \\
Weyburn Security Bank & $\$ 6,153,722$ \\
Barclays Bank (Canada) & $\$ 4,542,299$ \\
\hline
\end{tabular}

Note. Reprinted from Canada Year Book, 1930.

\subsection{The Bank of Canada}

Like other actors, the Great Depression had a significant impact on the Royal and, with the creation of the Bank of Canada in 1934, their relationship to the Canadian state was fundamentally altered. The Great Depression was caused by the collapse of the New 
York stock market on 'Black Tuesday,' October 29, 1929 and it quickly spread around the world. ${ }^{79}$ Between 1929 and 1939, Canada's GDP fell by $40 \%$ and unemployment reached $27 \%$ at its highest in 1933 (Norrie \& Owram, 1991). Corporate profits of \$398 million in 1929 quickly turned into losses of $\$ 98$ million as the prices of commodities continued to fall. Farming communities in the West were hit especially hard by the collapse of wheat prices. One of the more significant effects, however, was the freezing of credit, which had a knock-on effect on all other areas of the economy. The Bank of Canada was thus initially set up as a private institution empowered to regulate internal credit and foreign exchange, give the government impartial financial advice (that is, advice on behalf of capital) and use monetary action to avoid economic crises. ${ }^{80}$ In return for these services, the chartered banks surrendered their right to issue notes (thus ending Canada's distinctive medley of banknotes; see, e.g., Gilbert [2003]) as well as their gold reserves. The federal government now guaranteed the Dominion's note circulation and assumed the risks of being the 'lender of last resort.' Four years later, prime minister Mackenzie King nationalized the entire operation; in doing so, he would essentially bring a central

79 For an excellent overview of the conditions leading to Black Tuesday, see Gordon Thomas and Max Morgan-Witts' (1979) The Day the Bubble Burst: A Social History of the Wall Street Crash.

80 The Bank of Canada provides this function by way of the chartered banks: "by changing the total amount of cash reserves available to the chartered banks, it can oblige them to adjust their portfolios of liquid assets and their willingness to compete for deposit liabilities" (Van Houten, 1991, p. 175). The $\mathrm{BOC}$ is also able to influence interest rates through the buying and selling of government securities, and "can affect short-term interest rates by manipulating the prime bank rate" (p. 175). 
element of the chartered banks' activities - credit creation - under the authority of the nation-state for the protection and development of the national political economy. ${ }^{81}$

Given the strength of the chartered banks, their longstanding desire to retain their right to issue notes, and their wish to keep the government at arms-length from their operations, the creation, and subsequent nationalization, of the Bank of Canada can be seen as a sort of last-ditch effort to stabilize Canada's national political economy during the Great Depression - albeit one that was supported by the Royal bank as early as 1918 for the purpose of ending "the suzerainty of the Bank of Montreal as the government's banker" (McDowall, 1993, p. 156). The power of the chartered banks can be seen in the reaction to the failure of the Home Bank on August 18, 1923. Originally founded in 1854, the failure of the Home Bank was the result of poor loans and fraud alongside a recession created by the chartered banks by raising interests rates in 1920 in an attempt to control rising prices. As the demand for credit fell, the resulting recession drove prices down dramatically, making many assets worth less than the money that was initially loaned to acquire them. In this case the Home Bank was the one left holding the bag; in the aftermath, 10 officials from the Home Bank were arrested on charges including fraud, and 60,000 prairie farmers lost their life savings, prompting Prime Minister Mackenzie King to launch a Royal Commission into the cause of the failure in 1924.

81 As Van Houten (1991) notes: "In 1938, the government nationalized the Bank of Canada. Four years earlier, the Bank of Canada Act had empowered the bank to determine the total amount of cash reserves available to the chartered banks and therefore gave it control over the rate of expansion of the total assets and liabilities of the banking system as a whole. Nationalization transferred that power to the state" (p. 83). 
In this context, and having earned full legislative powers over internal and external affairs in 1931 as a result of the Statute of Westminster, Prime Minister Bennett asked the CBA to consider a form of central bank in 1931 "because he hoped it would lessen the country's dependence on New York banks that he believed controlled the value of the Canadian dollar" (Helleiner, 2003, p. 153). Bennett was not just influenced by nationalist concerns, however, but also "by pressure from more left-wing forces who gained strength during the Depression and demanded more activist monetary policies" ( $\mathrm{p}$. 153). Indeed, public sentiment had shifted strongly against big capital since the 1920s and the chartered banks were no exception. Their increased usage of Section 88 of the Bank Act, which allowed them to seize cattle, tractors, and other farm implements to settle debts, had made them increasingly unpopular in the prairies. After a Saskatchewan MP told Bennett that the Royal Bank manager in Borden was " "simply taking the shirts off the backs of the people' by exercising his Section 88 prerogatives, Bennett warned the bank's head office that such incidents fed political radicalism-'the nourishment upon which the Woodsworth faction feeds"' (McDowall, 1993, p. 248). ${ }^{82}$

Since the chartered banks were concerned that a central bank could "fall under the thrall of politicians" (McDowall, 1993, p. 27) they instead joined Canada's other large corporations in calling for a merger of the Liberal and Conservative parties in order to create the political conditions to avoid national insolvency by amalgamating the publiclyowned but debt-burdened Canadian National Railway (CNR) with the privately-owned

82 Bennett also told the president of the CBA that "it is idle to expect any member of Parliament or Canadian citizen for that matter to justify some of the acts of the banks in driving customers to the wall who are unable to liquidate their liabilities under existing circumstances" (McDowall, 1993, p. 248). 
CPR. ${ }^{83}$ As the historian Don Nerbas (2013) notes, the plan was little more than an attempt to "shore up the old political economy and restore the power of capital" (p. 147). Indeed, Mackenzie King argued that the plan would end up sacrificing "democracy to serve the ends of plutocracy" (as cited in Nerbas, 2013, p. 146) alongside elevating the Canadian Commonwealth Federation (CCF) — whose platform included the nationalization of the chartered banks - to the status of official opposition. ${ }^{84}$ Instead, a different plan was worked out where the chartered banks would advance credit to beleaguered infrastructure project in exchange for a $\$ 12.2$ million share of a $\$ 60$ million loan to the CPR to stop it "from defaulting on a series of short-term obligations that could not be financed on troubled Wall Street" (McDowall, 1993, p. 269). While their original plan was unsuccessful, it demonstrates the extent to which the chartered banks were willing to go in order to retain their rights and privileges; their solution was disturbingly similar to other forms of authoritarianism that were emerging in other, formerly liberal-democratic, countries. Their own attempts to 'solve' the issue were eventually thwarted by the results of a Royal Commission on Banking and Currency (1933) which asked a number of basic questions about the operation of the banking system:

To what extent and through what organizations should the volume of credit and the currency be regulated? On what body should lie the primary responsibility for maintaining the external stability of the country's currency? To what institution

83 Bennett had already been warned by the Governor of the Bank of England, Montagu Norman, "'that Canada was heading towards national insolvency,' and if nothing was done 'about the railway problem it would break the country"' (as cited in Nerbas, 2013, p. 141).

84 "The leader of the CCF, M.J. Coldwell, pushed for bank nationalization, arguing that the creation of national credit should not be left in the hands of 'irresponsible boards of directors'" (McDowall, 1993, p. 304). 
may the Government of the day be most suitably turn for informed and impartial advice on matters of financial policy? (p. 62).

As the Commission noted: "in the great, and an increasing, majority of countries the answers to these questions has been found in the existence or the creation of a central bank" (p. 62). Indeed, as Germain (2010) notes, the 1920s had marked the first great wave of central bank expansion as countries around the world attempted to deal with new problems relating to the development of their respective financial systems, with the final national level of innovation coming in the 1930s "as a consequence of the collapse of stock markets and the onset of the Depression" (p. 32). As the Royal Commission (1933) puts it plainly: "as an instrument [the central bank] is the means by which the statewhich must necessarily retain ultimate sovereignty in matters affecting the currency—can give effect to the national policy" (p. 63). The stage was therefore set for a shift in authority away from the chartered banks and toward the institutions of the nation-state.

For the Royal specifically, their activities over this period make clear just how necessary the Bank of Canada was to reproducing Canadian capitalism in the context of the Great Depression. Profits made during the First World War had enabled all the chartered banks to export capital to Britain, the United States, and the various British Caribbean colonies. These profits were primarily derived from their new relationship with the nation-state as a result of the Finance Act and the creation of war bonds, which 
the banks underwrote. ${ }^{85}$ In an attempt to establish themselves in Germany, the Royal had started to provide loans to German banks through its New York, London, and Paris offices. They were already owed $\$ 9.4$ million by 1930 when the conditions of post-war Germany (hyper-inflation and social instability) caused the Weimar Republic to sign a Standstill Agreement in 1931, halting all their foreign debt obligations. In combination with the earlier collapse of the Cuban sugar industry, the collapse of wheat prices, and the general financial conditions of the Great Depression, the Royal was out roughly $\$ 33$ million. In 1932, the Canadian government would attempt to extend some credit to the chartered banks by allowing them to borrow $\$ 35$ million at 3\%, which was subsequently loaned back to the government at 4\%. As McDowall (1993) notes: "it had little or no impact on credit conditions" (p. 269).

To avoid immediate collapse, the Royal first attempted to take over their debtors' stock, but were legally blocked from doing so by the Bank Act. They were, admittedly, in a difficult situation, since "among the $\$ 23$ million in questionable domestic loans were the businesses of some of Canada's premier financiers: T.B. Macaulay, Harry Gundy, and, indirectly, Herbert Holt" (McDowall, 1993, p. 257). As McDowall (1993) notes, any attempt to force the liquidation of these accounts would necessarily provoke a major crisis of confidence in Canadian business: "Who in the bank, after all, would have the temerity to demand repayment of a \$2.9-million loan to the Consolidated Investment

85 "The 1918 target of $\$ 300$ million was overshadowed by a $\$ 690$ million result from over a million subscribers. 'That we are able to handle these gigantic sums is amazing,' Pease confided to a friend. 'It is proof of the great increase in the wealth of the country since the war began. It is hard to believe that in addition to taking care of the government requirements and the flotation in Canada of $\$ 350,000,000$ of domestic loans, the deposits of the banks today are $\$ 500,000,000$ greater than they were before the war began (McDowall, 1993, p. 216). 
Corporation, a 1929 Holt holding-company creation” (p. 257). The bank's solution was simply to break the law. Three of the Royal's directors-A.J. Brown, G.H. Duggan, and, Herbert Holt — created the Islemont Securities Corporation, which, after taking a loan from the Royal for $\$ 7,992,780$ secured with $\$ 8$ million of its own 20 year collateral trust bonds, began to purchase large blocks of Royal shares from their debtors, thus easing the bank's overall debt-load. As McDowall (1993) notes: "the tactic was quickly mimicked to relieve the pain of debt elsewhere in the portfolio" (p. 260). ${ }^{86}$ An order-in-council from Prime Minister Bennett also allowed the Royal to "value securities they then held at prices higher than the depressed market prices" (Park \& Park, 1962, p. 55) ${ }^{87}$ While some of the chartered banks still held to their earlier position that the Finance Act provided a more than adequate means of creating credit and that "the profits they garnered from circulating their own notes helped to pay the costs of running a national branch system" (McDowall, 1993, p. 273), it was becoming increasingly clear that a central bank would help avoid such crises in the future, especially in the context of the more general wave of central bank creation in the 1920s (Germain, 2010, p. 31). In order to offset the loss of some of their rights and privileges, the Royal got one of their own, assistant manager Graham Towers, appointed as the first governor of the Bank of Canada. As reported in the New York Times (1934) the choice of Towers over a Bank of England man was due to "fear[s] that Canada's finances might be controlled by London" (p. 37).

86 McDowall (1993) also notes that it was "no coincidence that, in 1934, the Bank Act was revised to prohibit a bank director from voting approval for any loan to a concern in which he held an interest" (p. 261).

87 It is perhaps no surprise that after his retirement from politics in 1938, Bennett was promptly made a director of the Royal. 
While the Bank of Canada allowed the chartered banks to "entertain ideas of credit expansion at the end of the decade" (McDowall, 1993, p. 283) it also changed their relationship with the nation-state. Not only were they now subject to new political pressures as a result of the central bank's nationalization, but they "could no longer count on their informal confabs with the finance minister to make sure their views were understood" (p. 276). Instead, they had to increasingly rely on "paid lobbyists, radio 'propaganda,' and advocacy programs to preserve their stake in Canadian society" (p. 276). Much of this propaganda was directed against those political parties—Social Credit and the Co-operative Commonwealth Federation (CCF) — that directly challenged their power, especially in the West. ${ }^{88}$ The creation of the Bank of Canada meant that "Canadian banking would never be the same again" (McDowall, 1993, p. 272). The chartered banks had lost significant rights in return for their security and were now subject to 'political' pressures like never before.

88 For instance, there was a CBA-promoted speaking tour by famous writer and former Royal employee, Stephen Leacock: “'I spoke,' Leacock reported, 'on literary, humours and college stuff, and on Social Credit"' (McDowall, 1993, p. 282). For more on the class context of Alberta during this period see Macpherson (1953/2013). 
Table 4

Bank Absorptions in Canada, 1867-1928

\begin{tabular}{|c|c|c|}
\hline Purchasing Bank & Bank Absorbed & Date \\
\hline \multirow[t]{7}{*}{ Bank of Montreal } & Exchange Bank & August 13,1903 \\
\hline & People's Bank of Halifax & June 27,1905 \\
\hline & Ontario Bank & October 13, 1906 \\
\hline & People's Bank of New Brunswick & April 15, 1907 \\
\hline & Bank of British North America & October 12,1913 \\
\hline & Merchants Bank & March 20, 1922 \\
\hline & Molsons Bank & January 20, 1925 \\
\hline Canadian Bank of & Gore Bank & May 19,1870 \\
\hline \multirow[t]{5}{*}{ Commerce } & Bank of British Columbia & December 31, 1900 \\
\hline & Halifax Banking Co. & May 30, 1903 \\
\hline & Merchants Bank of P.E.I. & May 31, 1906 \\
\hline & Eastern Townships Bank & February 29, 1912 \\
\hline & Bank of Hamilton & December 31, 1923 \\
\hline \multirow[t]{4}{*}{ Bank of Nova Scotia } & Union Bank of P.E.I. & October 1,1883 \\
\hline & Bank of New Brunswick & February 15, 1913 \\
\hline & The Metropolitan Bank & November 14,1914 \\
\hline & The Bank of Ottawa & April 30, 1919 \\
\hline \multirow[t]{5}{*}{ Royal Bank of Canada } & Union Bank of Halifax & November 1,1910 \\
\hline & Traders Bank of Canada & September 3, 1912 \\
\hline & Quebec Bank & January 2, 1917 \\
\hline & Northern Crown Bank & July 2, 1918 \\
\hline & Union Bank of Canada & August 31, 1925 \\
\hline Imperial Bank of Canada & Niagara District Bank & June 21,1875 \\
\hline Standard Bank of Canada & Western Bank of Canada & February 13, 1909 \\
\hline Banque d'Hochelaga & Banque Nationale & April 30, 1924 \\
\hline Bank of New Brunswick & Summerside Bank & September 12,1901 \\
\hline \multirow[t]{2}{*}{ Merchants Bank of Canada } & Merchants Bank & February 22,1868 \\
\hline & Commercial Bank of Canada & June 1,1868 \\
\hline Union Bank of Halifax & Commercial Bank of Windsor & October 31, 1902 \\
\hline \multirow[t]{2}{*}{ Northern Crown Bank } & The Northern Bank & July 2, 1908 \\
\hline & Crown Bank of Canada & July 2, 1908 \\
\hline Union Bank of Canada & United Empire Bank & March 31, 1911 \\
\hline Home Bank of Canada & $\begin{array}{l}\text { La Banque Internationale du } \\
\text { Canada }\end{array}$ & April 15, 1913 \\
\hline
\end{tabular}

Note. Reprinted from Canada Year Book, 1927-28. 


\subsection{Conclusion}

Against contemporary theories of Canadian imperialism and dependency that treat globalization as similar in content and form to the type of capitalism that characterized the late 19th and early 20th centuries, this chapter set out to explore how this earlier period of TAR was constituted in respect to capital. I argued that this period can be distinguished from our present epoch by the creation of a national system of property relations; that is, a centripetal organizing dynamic of TAR toward the national level. My main claim is that as a result of this drawing in, this period should be understood as the making of what we have come to call national capital. This form of capital rested on the construction of a nation-state; that is, a domestic market within a certain territory. ${ }^{89}$ The main role of the state during this period was to protect the rights of private property necessary for the market to function and to extend the territory on which this market operated, thus making the national epoch of capitalism one characterized by various forms of imperialism and nationalism. By virtue of this drawing in of TAR, I argue that the institutions of the state were transformed into a capability for the growth of domestic capital via both the extension of territory, as well as by providing protection against the contradictions of the accumulation process. In colonies like Canada, this process took place later than other European states, but took place nonetheless. As Sassen (2006)

89 Although speaking about the United States, Sassen (2006) captures the spirit of the age: "This period saw the establishment of basic governing institutions, the acquisition and distribution of new territory, the promotion of national and international commerce, the development of a powerful national defence and a formalized yet flexible national legal system, and the growth of aggressive policies of regulation, administration, and redistribution" (p. 124). 
notes, that "the various colonizing efforts took place within the frame of the domestic and imperial expansion of national capitalisms" (p. 140).

To demonstrate the empirical reality of this transformation, I provided an analysis of the transformation of Canadian banking via the history of the Royal Bank of Canada from 1864 to 1939. I identified four shifts in TAR —Confederation and the Bank Act, the National Policy, the Finance Act, and the Bank of Canada - to represent this drawing in as it relates to the chartered banks. Through Confederation and the Bank Act, the rights of banking were standardized and brought to the national level where they were enforced by the institutions of the new nation-state, the Dominion of Canada; the territory on which the banks could operate was also extended across the continent by virtue of the National Policy. The main struggle during this period in respect to the banks was in the form of capitalist competition between the chartered banks themselves (in particular, the Bank of Montreal versus the other chartered banks) as well as between the chartered banks and the federal government over the rights of banking. As the dynamics of accumulation played themselves out, the nation-state was forced to take increasing control over the creation of credit in the form of the Finance Act, and, eventually, the currency itself via the creation of the Bank of Canada. I claim that these shifts in TAR transformed the state into a capability for the growth of the chartered banks by enabling them to expand and by protecting them against external competition, as well as the contradictions of their own accumulation activities. As we will see in the next chapter, while these shifts in TAR made the state into a capability for the growth of national capital, it would soon become a fetter on this growth, leading capital to seek out new, unregulated international activities. 


\section{The Expansion of National Capital: The Growth of the Royal Bank of}

\section{Canada, 1940-1974}

Towards the end of his presidency, Earle McLaughlin reflected that the Eurodollar was 'a pretty good invention. I don't know what we would do without it.'

—Duncan McDowall, Historian of the Royal Bank of Canada, 1993.

\subsection{Introduction}

In the last chapter, I explored how the mid-19th century through the early 20th century was constituted in its configuration of territory, authority, and rights (TAR) in respect to capital in Canada. I was mainly concerned with exploring the wider questions of how the property relations that sustained capitalism over that period were organized and how they contributed to the making of what we call national capital. I argued that this period of capitalism can be distinguished by virtue of the creation of a national system of property relations - that is, by a centripetal organizing dynamic that drew TAR into the national level—which made the state into a capability for the growth of domestic capital.

In this chapter, I extend this analysis into the mid-20th century. The reason for doing this is, like before, to more clearly define the differences in TAR that mark the boundaries of our emerging global epoch. As such, I am not concerned here with the divergent interpretations of the 'facts' of this period as provided by theories of Canadian dependency and imperialism, which are then used to provide evidence as to the character 
and nature of Canada's capitalist class. ${ }^{90}$ Instead, I am more concerned with the particular configuration of TAR that sustained capital over this period and what it enabled capital to do so that we can better appreciate the differences between the national epoch of capitalism and our emerging global epoch. Put simply, my argument in this chapter is that the period from 1940 to 1974 represents the interregnum between the national and global epochs of capitalism; on the one hand there is the emergence of increasing levels of global economic activity, but still within the context of a world economy constituted by national systems of property relations.

I make this argument on the basis that the period begins with a continuation of the centripetal organizing logic that characterized the earlier period of capitalism; that is, a continued drawing in of TAR to the national level. Despite increasing levels of global economic activity, the rights of capital and the authority over those rights remained primarily at the nation-state level, giving national governments a number of options to regulate and control capital flows. I identify the Bretton Woods system as one indicator of this intensification. While there is little doubt that Bretton Woods made possible an "unrelenting capitalist internationalization" (Carroll, 1986, p. 188) within the context of a larger "boom in the world economy under American hegemony" (Watkins, 1989, p. 30) I argue that it is wrong to treat this period as an extension of our present global epoch since Bret-

90 Theories of imperialism, for instance, tend to see the period as characterized by a more general internationalization of capital, in which there is an "enlarged presence of U.S.-controlled monopoly capital in Canada, together with an intermingling of powerful U.S. financial groups within Canadian finance capital" (Carroll, 1985, p. 45). In contrast, theories of dependency see the vast increase in American investment in Canada over this period as further evidence of the subordinate status of Canada's capitalist class. While there is a recognition that this period was one "of prosperity for both the United States and Canada" (Watkins, 1989, p. 30) the overall view of dependency theories is that Canada remained "the most important colony of the U.S." (Teeple, 1972, p. xii). 
ton Woods did all this without requiring nation-states to relinquish their authority to manage or participate in the national economy, as is the case today. For the most part, the period was characterized by nation-states protecting their domestic capitals from external forces. As put by Robert Cox (1981): "welfare nationalism took the form of economic planning at the national level and the attempt to control external economic impacts upon the national economy" (p. 146). The relative success of this sort of protection would have the result, however, of increasing competition among domestic financial institutions, leading many national banks to find new ways of escaping national regulatory control in the form of the Eurodollar markets. While these events took place within the more general centripetal organizing dynamic of the period, I claim that the collapse of the Bretton Woods system under the weight of the Eurodollar markets should be understood as a tipping point, ushering in a global organizing dynamic of TAR that remains with us today. In the next chapter, I argue that we should understand this shift as the emergence of a global system of property relations, and thus, the beginnings of the making of global capital.

The chapter proceeds as follows. First, I explore why the Bretton Woods system should be understood as part of the national epoch of capitalism, especially as it relates to banking and finance. Next, I focus on the more general effects of Bretton Woods on the Royal Bank of Canada. I argue that the relatively closed national economy engendered by this system led to increased domestic competition from the 'near banks' and that this, in turn, led the Royal, as well as the rest of the chartered banks, to expand themselves via the Eurodollar markets. While these markets allowed the chartered banks to grow ex- 
tremely large, the massive flows of foreign currency that they generated eventually overwhelmed the Bretton Woods system. I conclude by highlighting some of the reasons why we should understand the collapse of this system as the tipping point into our current global epoch, as well as some of the larger consequences for banking and finance.

\subsection{The Bretton Woods System}

The end of the Second World War brought significant shifts to TAR in respect to banking. One of these shifts was the Bretton Woods system, which was the result of the 1944 United Nations Monetary and Financial Conference held at Bretton Woods, New Hampshire. The conference set out a system of fixed exchange rates pegged to the U.S. dollar, which was subsequently pegged to gold, allowing the United States to run a trade deficit without devaluing their currency. Henwood (1998) provides a simple explanation of the system:

Unlike the classic gold standard, in which all countries expressed their national currency in terms of gold, the Bretton Woods system used the dollar as the central value, and the dollar in turn was fixed to gold. Countries could hold dollar reserves in their central bank for the settlement of international trade and finance on the knowledge that they could cash those dollars in for a fixed amount of gold. The dollar, as was said, was as good as gold (p. 43).

The Bretton Woods system also included the creation of the International Monetary Fund (IMF) to provide short-term loans to countries having balance of payments problems to give them time to make the proper adjustments without the deflationary consequences of 
an automatic gold standard; it also included the creation of the World Bank, which was, as Cox (1981) notes: "a vehicle for longer term financial assistance" (p. 145).

The development of the Bretton Woods system has since led many scholars to argue that it was either the beginning of the global epoch (e.g., Burbach \& Robinson, 1999; Hardt \& Negri, 2000; Robinson, 2004; Teeple, 2000) or, alternatively, that there has been no qualitative change to the global political economy since the system's demise (e.g., Arrighi, 1994/2010; Eichengreen, 1996/2008; Panitch \& Gindin, 2012; Wood, 2003). As Sassen (2006) notes, this is because many elements of our contemporary period mirror aspects of the Bretton Woods era:

These include micro trends such as the rise of the transnational banks alluded to earlier and the establishment of various multilateral systems for economic operations, including the IMF and the World Bank, which continue to be central organizations in the current global era. Further, key demands by the United States in the framing of the Bretton Woods system were akin to the later neoliberal policies of the 1980s and 1990s, making it easy to argue that the current global phase had already begun then or, alternatively, that there is nothing distinct about the global phase of the 1980s onward (p. 159).

We need to be wary, however, of treating Bretton Woods as either evidence of American imperialism in the Canadian context or as the beginning of our global epoch. First, while the new institutions of the Bretton Woods system could be understood to be part of the imperialism of the United States, they were certainly not imposed on Canada's ruling class. Indeed, as noted by one of the participants, A.W.F. Plumptre (1977): 
It is true, and it was true at the time, that the new international institutions, largely fashioned in Washington, were designed to serve the international interests of the United States. The charge that they could in many respects be considered as the creatures of American 'capitalist imperialism' can in a sense be accepted. It does not follow, however, that their establishment and operation were contrary to Canadian interests as perceived at the time or subsequently by Canadian governments or Canadians generally. The kind of postwar world the Americans, in collaboration with the British, were attempting to build was one that was in large measure well adapted to Canadian requirements, and as a result of Canadian efforts the adaptation was improved (p. 31).

Furthermore, once Bretton Woods was not well adapted to Canadian requirements, the government was able to simply operate differently. A good example being the decision to float the Canadian currency in 1950 in order to continue the flows of American capital into Canada. While Canada would eventually re-peg their currency to the American dollar in 1962, the earlier decision to un-peg belies the characterization of a Canadian ruling class dominated by American interests.

Second, unlike today's so-called free trade agreements, the Bretton Woods system did not reduce the ability of nation-states to regulate capital, but rather, strengthened it. Where the international monetary order had previously been more or less in the hands of private bankers and financiers, Bretton Woods gave control of this system to a series of government regulatory bodies. As such, the multilateralism of Bretton Woods did not prevent state economic coordination or national protectionism (as is the case today) and 
instead enhanced the ability of the nation-state to be used in such a way. As Helleiner (1995) notes, Bretton Woods granted nation-states "the explicit 'right' to use capital controls" (p. 317) which are rules regulating the cross-border movement of money. In other words: "the capital account was understood to be a legitimate subject of control for governments" (Germain, 2010, p. 50). By granting nation-states the right to use capital controls, the Bretton Woods system not only enabled nation-states to develop capabilities to protect national economies from external forces, but did so without restricting the ability of national "governments to manage their economies and function as significant economic actors" (Sassen, 2006, p. 161). Indeed, as Germain (2010) notes: "the central innovation of the Bretton Woods agreements concerned the acceptability of these controls in the name of enhancing and preserving monetary stability" (p. 51).

Even the General Agreement on Trade and Tariffs (GATT), which is sometimes identified as the beginning of the global epoch by those who see it as the "institutional means for a negotiated removal of all national barriers to world trade" (Teeple, 2000, p. 54), was never meant to eliminate all trade barriers between countries as is the case with today's so-called free trade agreements (as I discuss in chapter six, NAFTA was crafted in such a way as to be extended to other countries over time; it has since provided the model for other free trade agreements such as the Canadian-European Union Trade Agreement [CETA] and the currently stalled Trans-Pacific Partnership [TPP]). The GATT was merely a provisional agreement that "aimed at dismantling some of the protectionist measures that had built up over the previous two decades" (Brummer, 2014, p. 43). Not only were both the Bretton Woods system and the GATT far "more tolerant of politically diverse 
choices at the national level" (McBride, 2005, p. 144), but they both allowed for "the liberalization of trading rules with a considerable degree of state autonomy in policy making” (p. 145). As legal scholar Chris Brummer (2014) notes, the GATT was also relatively limited in scope, leaving a wide range of sectors untouched- "from financial services to construction to, perhaps most importantly, agriculture" (p. 43). It also had weak enforcement powers: GATT panels only had "limited disciplinary power beyond stigmatizing countries as non-compliant with their treaty obligations" (p. 43).

This is in great contrast to today's free trade agreements, which restrict nationstates from legislating against corporate interests. As such, we should understand the extent and content of government control during the Bretton Woods era as making for a "substantively different international financial system from what gets launched in the 1980s" (Sassen, 2006, p. 160). Regardless of the international and multilateral character of the Bretton Woods system and the role of American dominance in shaping that system, it was still fundamentally "aimed at building the national economy and polity. The project was governing the international system in order to protect the national interest, no matter the definition of the latter" (p. 161). This is why we should understood the Bretton Woods era as part of the national epoch of capitalism; it was an institutional framework to govern national systems of property relations. In other words, the rights of capital continued to be located at the national level and were still enforced and protected by nation-states that had a considerable amount of autonomy (when compared with today) as to how governments went about doing that. We should thus understand this period as a continuation and intensification of the earlier centripetal organizing dynamic that had been building 
over the previous decades; a dynamic that was geared toward developing and building up

national capitals.

The reality of this can be seen more clearly by reflecting on the specific results of Bretton Woods on Canadian banking as well as the changing activities of the Royal during this period. It is important to note that the Bretton Woods system emerged in response to a number of ad hoc exchange controls created to protect national political economies from the vagaries of the Great Depression and the Second World War. ${ }^{91}$ As Christophers (2013) notes, during this period, "the world of international money and banking shrunk back from its previously open and integrated configuration to become, in short order, a collection of largely self-contained financial islands" (p. 103). This meant that banking began to occur more within borders than across them as various forms of exchange were restricted; as such, there was an increase in the significance of foreign branches that could capture the business of multinational corporations (MNCs) operating in new territories to avoid tariff walls. ${ }^{92}$ Quigley (1986) notes, for instance, that the Royal used their

91 For instance, in Canada, exchange controls were introduced through an Order-in-Council passed on September 15, 1939 as part of the War Measures Act, which, through the Foreign Exchange Control Order, established a legal framework for the control of foreign exchange transactions via the Foreign Exchange Control Board (FECB). On April 30, 1940, these controls were stiffened even further, requiring all Canadian residents (including the Bank of Canada) to sell all foreign currency that they owned to the FECB. Powell (2010) provides more detail: "To conserve Canada's foreign exchange and effectively support the value of the Canadian dollar, the Board introduced extensive controls. These controls allowed the Board to regulate both current and capital account transactions, although most current account transactions, other than travel, were treated fairly leniently. Permits were required for all payments by residents to non-residents for imports of goods and services. Permits were also required for the purchase of foreign currencies and foreign securities, the export of funds by travellers, and to change one's status from resident to non-resident. Residents were also required to sell all foreign exchange receipts to an authorized dealer. Interbank trading in Canadian dollars ceased" (p. 54).

92 As Norfield (2016) notes, this had the effect of privileging national financial institutions by virtue of their ability to 'lean' on their home currency: "as capitalism expands to create a world market, the operations of financial companies expands alongside those of commerce and industry. In this, too, they receive support from their national base - if only in the national currency to which they have privileged access via the home central bank. Access to the home currency is commonly their area of advantage over banks and financial institutions in other countries" (p. 67). 
head office in Montreal and their New York agency for exactly this purpose: "as centres for co-ordinating the bank's pursuit of multinational corporations" (p. 37). Although American law restricted them from taking direct deposits, their location on the doorstep of the New York money market made this a non-issue. Well-positioned (literally) to access international trade and corporate accounts, the Royal established a trust-company affiliate in New York — the Royal Bank of Canada Trust Company—-that allowed them to act as "registrar and paying agent for corporate and government clients issuing bonds on the New York market" (McDowall, 1993, p. 289).

The move to New York was one that was simple enough in banking terms, but was also representative of much larger shifts in TAR in the world economy. Although the Royal had made significant profits off their London operation (conveniently located across the street from Canadian Army Headquarters) it was clear that New York was quickly becoming the centre for what still remained of international finance: "with London trapped under a blanket of war regulation, New York prospered" (McDowall, 1993, p. 289). Despite noting publicly in their June 1949 Monthly Letter "the degree to which [Britain's] economic recovery is bound up with Canada's own economic future," the Royal's general manager, James Muir, gave a much different interpretation nine years earlier, stating: "I have lost neither love nor loyalty for the old kingdom but I do think I see its plight rather more clearly than those who live too close to the forest" (as cited in McDowall, 1993, p. 290).

The shift from London to New York occurred at the same time that the rest of the world was beginning to shake off the last vestiges of colonialism, itself evincing a larger 
centripetal shift in TAR at the world scale: the proliferation of the nation-state form. ${ }^{93}$ Within a single decade of the end of the Second World War, national liberation movements arose in most of the colonial world: in Vietnam, Malaysia, Dutch East Indies, Korea, the Philippines, and India; in Algeria, Egypt, and Kenya; and in the Middle East. These movements were often accompanied by the desire for financial sovereignty. For the Royal, this was most explicit in the Caribbean and Latin America. In 1939, for instance, the Royal was forced to leave Panama "after the republic passed legislation requiring the banks to make compulsory purchases of state bonds" (p. 315). Similarly, in 1946, the nationalization of Argentina's central bank forced "all banks in the country to act as its agent" (p. 315). ${ }^{94}$

While banking was still international in the sense that foreign branches continued to exist, there was less cross-border banking activity, and what banking activity remained in foreign countries was now increasingly subject to the political whims of domestic governments (a point I discuss in greater detail below). Indeed, even in Canada, there were growing calls for various forms of protectionism that forced the Royal to take to the media to argue that the country did not have to choose between industrial development and free trade. Jeffees (1952) writes in the Globe and Mail, for instance, that Muir "believes that tariff protection tends both to retard and to conceal the true efficiency of a nation's

93 Wimmer and Feinstein (2010) note that this period constitutes the largest growth of nation-states by virtue of anti-colonial movements in British Asia and the Middle East, French and British Africa. Other significant periods of nation-state creation include the fall of the Hapsburg and Romanov empires after the First World War and the fall of the Soviet Union.

94 Lest the reader start to feel sorry for the Royal, things at this time were not all bad. In 1950, Cuba created their own central bank and refused to accept American dollars as legal tender. The Royal gladly accepted the change by providing technical advice as part owner of the Banco Nacional de Cuba; as such, "by the decade's end, the Royal Bank was still Cuba's largest bank, with annual deposits averaging over \$100 million" (McDowall, 1993, p. 315). 
industry" (p. 20), and that "there is little doubt in his mind that "Canada can achieve both industrial development and free trade' and he thinks that the Canadian problem is to hasten the process" (p. 20). ${ }^{95}$ All this is to say, however, that with international capital flows constrained, the national economy began to take on a greater importance; and this meant an increase in domestic competition that would ultimately (and perhaps, ironically) lead to the globalization of financial capital.

\subsection{Domestic Competition}

The relatively closed national economy of the Bretton Woods era brought with it new configurations of TAR that are still evident to different degrees among the various liberal democracies. While these new configurations would help protect capital from external forces (thereby enabling corporations to grow extremely large) they would also cause an increase in domestic competition, and thus, new ways of escaping national regulatory control. For the most part, these configurations were initiated under the auspices of the so-called Keynesian Welfare State (KWS), the name deriving in part from the work of economist John Maynard Keynes. I say so-called because, as sociologist Janet Siltanen (2002) points out, in Canada, like elsewhere, the emergence of Keynesian social reforms

95 Earlier, in 1948, the Royal rhetorically asked the readers of their Monthly Letter: "One of the perplexing questions for a country wealthy in natural resources is: how far should I forego a nationalistic economy in the interest of international good." As should be clear, the bank's answer to this question has always been 'pretty far.' 
tended to be ad hoc rather than part of a larger strategy of social citizenship. ${ }^{96}$ Indeed, as Göran Therborn (1984) notes, "parliamentary democracy and the welfare state forms seem to be institutional state traditions - of law, state structures and state-society relations - and class perspectives" (p. 17). As such, the timing of new applications and elaborations of institutional traditions, and the extent of the assertion of a particular class perspective should be seen as being determined, for the most part, by the balance of socio-political forces and by the conjunctures of capital accumulation (p. 17).

The actual and varied expressions of the welfare state across the capitalist world were thus far from the stated mark; one aspect of Keynes' thinking, however, would come to predominate in almost all of them: "above all, let finance primarily be national" (as cited in Christophers, 2013, p. 109). As Teeple (2000) notes: "the principal assumption in [Keynes'] work was the existence of a national economy in which, he argued, the state could intervene to influence levels of investment and domestic income and thereby partially regulate unemployment through national 'demand management' policies" (p. 17). Actual state intervention thus came in a variety of forms depending on the balance of socio-political forces in each country, but it typically included some level of socialization of the costs of production through state credits, guarantees, grants, and concessions, as well

96 Siltanen (2002) notes: "While I recognize that there has been a profound deterioration in the range and level of social support and services available to Canadian citizens, I do question whether it is correct to see this deterioration as also a shift away from social citizenship. The question is whether these services and supports ever rested on accepted claims of the social rights of citizenship. Talk of equality and rights may have been more tolerated, even welcomed, in the 'golden age,' but the proof of principle, especially on the part of governments, must be in actions and results. On these latter criteria, there does seem sufficient grounds to question whether the establishment of the social rights of citizenship ever grounded the welfare policy regime of the immediate post-World War II decades in Canada" (p. 402). 
as working-class reproduction through public works and various forms of income support. ${ }^{97}$ Unemployment insurance and family allowances were in place in Canada by 1945 , for instance. No matter their form, these state interventions relied on the "delimited national labour market and relative immobility of national capital in the relatively closed national economy, prior to the 1970s" (Teeple, 2000, p. 13).

For Canada's chartered banks, however, these new social rights meant "a monthly surge of cash passing from the government to the citizenry, most of which worked its way into the economy through the banks" (McDowall, 1993, p. 308). Government securities were now the largest component of the Royal's asset base (larger than its loan portfolio) and the surge in cash from the government to the citizenry was so large that the Royal was forced to set up their own Government Department at the Ottawa main branch to batch process government cheques by code. Furthermore, as a result of the Second World War, many of the Royal's traditional clients in power, food, raw metal, transportation, chemicals, and construction were reinvigorated: "familiar accounts-Acadia Sugar, National Drug \& Chemical, Price Brothers, Shawinigan Water \& Power-dramatically in-

97 There was a certain amount of support for these initiatives amongst government and corporate elites, who saw them as a way to create a 'golden age' of capitalism. We should thus be wary of seeing their emergence too simply as either a begrudgingly-given compromise from ruling classes or a hard-fought battle won by labour. McDowall (1993) gives an example from the Royal in which assistant manager Randolph Noble expresses his support for these policies to a friend: "In 1942, Principal James of McGill had given Ottawa its first glimpse of a planned and prosperous future in a report that advocated government support of key national industries like housing and agriculture. A year later, another McGill academic, Leonard Marsh, presented an even broader blueprint for peacetime 'social security.' The central thread of both reports was the avoidance of unemployment through the deliberate stimulation of prosperity. Government fiscal and monetary policy should be used to craft prosperity and to prevent any return to the social calamity of the thirties. 'I profoundly disagree with your theory that the rehabilitation of the world can be left to the haggling of the market,' Noble wrote to an American friend in 1944, 'in other words, to free enterprise"' (pp. 301-302). Indeed, as McDowall (1993) notes, Canada's chartered banks were "willing participants in the system of controls that Ottawa stretched over the economy" (p. 291). 
creased their borrowing” (p. 309). ${ }^{98}$ As a result, the Royal Bank would become the first Canadian bank to post assets of $\$ 2$ billion by 1945 ; in 1950 , their assets topped $\$ 2.5$ billion (Globe and Mail, 1951, p. 18).

Changes to the Bank Act in 1944 reflected the growing importance of the national consumption-based economy as the chartered banks were granted new rights allowing them to move into the realm of consumer loans. With Canada quickly transitioning from a country of farmers to a country of city-dwelling workers, "the government proposed that the Act be amended to allow the making of hitherto risky small loans under \$500” (McDowall, 1993, p. 304). ${ }^{99}$ In order to boost domestic consumption, the federal government also lowered the interest rate to $6 \%$, thus bringing the chartered banks into the consumer loan business. As McDowall (1993) notes: "these were the years in which Canadians learned to indulge their dreams on the 'never-never' plan" (p. 310). Here though, the chartered banks were outmanoeuvred by smaller finance and trust companies — referred to as 'near-banks' - that were not regulated by the Bank Act. The Royal publicly complained that this so-called 'easy consumer credit' can be costly both to the consumer and to the economy as a whole. The effect on sales is immediate and gratifying to business;

98 During this period the Royal would also make inroads into Quebec via the pulp and paper, aluminum, and hydro power sectors. Quebec's Premier, Maurice Duplessis, saw the Royal as a means of "integrating the province's resource base into the continental economy" (McDowall, 1993, p. 328).

99 As McDowall (1993) notes: "The cities would be the crucial post-war frontier for banking; the war put wages in people's pockets, and it was relatively easy to capture their business" (p. 308). This was because, as Heron and Storey (1986) note: "the traditionally large, flexible pool of underemployed, 'semiproletarianized' Canadian farm dwellers declined drastically after World War II as farmers' children left for the city in unprecedented numbers" (p. 20). See also, Johnson (1979) and Radforth (1986). 
but repayment of the debt by the public in the future may well result in an

enforced reduction in consumer spending (Globe and Mail, 1953, p. 8). ${ }^{100}$

A more likely interpretation is that the chartered banks were simply upset that they were not getting their cut of these new lending profits. They were still able to get a piece of the action, however, since "it was to the banks that the finance companies turned for their initial float of capital" (McDowall, 1993, p. 311). For their part, the Royal secured the "steady patronage of Household Finance and General Motors Acceptance” (p. 311).

Table 5

Branches of Canadian Chartered Banks in Canada, 1950

\begin{tabular}{|l|l|}
\hline Bank & Total No. Branches \\
\hline Royal Bank of Canada & 677 \\
Canadian Bank of Commerce & 504 \\
Bank of Montreal & 486 \\
Bank of Nova Scotia & 329 \\
Banque Canadienne Nationale & 230 \\
Bank of Toronto & 199 \\
Imperial Bank of Canada & 190 \\
Dominion Bank & 138 \\
Provincial Bank of Canada & 133 \\
Barclays Bank (Canada) & 4 \\
\hline
\end{tabular}

Note. Reprinted from Canada Year Book, by Statistics Canada, 1950.

100 This message was merely a repeat of that given to the Royal by the governor of the central bank three years earlier: "In November 1950, Ted Atkinson of the Royal Bank came to Ottawa to tell Towers that 'the wave of optimism' sweeping the Canadian economy was 'still fairly high.' The governor of the central bank responded that the banks had better cool consumer and commercial demand for credit. Towers would habitually urge the general managers to 'weed out some of the less urgent demands on our resources.' When James Coyne succeeded Towers as governor in 1955, the message remained unchanged: 'a remedy must not be sought in monetary expansion or deficit financing'" (McDowall, 1993, pp. 324-325). 
The significant factor in the chartered banks' distaste for the near-banks was their freedom from the constraints of the Bank Act. Where the chartered banks were constrained by the Bank Act's 6\% interest ceiling, the near-banks could lend at whatever interest rate they wanted. As such, when the prime rate rose to levels that denied the chartered banks a sufficient spread between the cost of lending and the ceiling, they were forced to stop providing loans. The near-banks, on the other hand, simply moved their rate up. Furthermore, since the chartered banks were subject to different reserve ratios, the near-banks had more flexibility to manoeuvre. The 1954 Bank Act, for instance, obliged the chartered banks to "to keep at least $8 \%$, and if requested, as much as $12 \%$, of their deposits with the Bank of Canada as a cash reserve" (McDowall, 1993, p. 332). By offering small instalment loans to consumers, or credit toward the purchase of automobiles, the near-banks were thus able to capture an increasing proportion of the total assets of the financial sector: "by $1954 \ldots$ the banks supplied only $15.6 \%$ of Canadian consumer credit” (p. 332). The chartered banks responded by convincing the government to amend the Bank Act in 1954 so that they could provide mortgage loans, chattel loans (e.g., car or household), and loans made against the security of hydrocarbons in the ground. ${ }^{101}$ While mortgages were only around 5\% of the Royal's outstanding debt in

101 The right to lend on the basis of hydrocarbons in the ground was a reflection of the discovery of oil in Leduc, Alberta in 1947. As the largest bank in the Alberta oil fields, the Royal quickly came to be referred to as the "'R-oil' Bank" (McDowall, 1993, p. 384). By 1953 the Royal had accounts of $47 \%$ of the companies listed in the Alberta oil directory; by 1967, this would rise to $53 \%$, with the bank capturing $75 \%$ of new business in the oil patch, a trend later reinforced by the soaring energy prices of the 1970 s. 
1945 this ballooned to $20 \%$ by $1962 .{ }^{102}$ The Royal's president defended their growth by stating that the bank merely wanted to put "greater purchasing power in the hands of the individual" (Hudson, 1959, p. 3). This lending trajectory would change, however, after the federally-sanctioned mortgage rate crossed the $6 \%$ limit in 1959 :

James Muir, chairman and president of the Royal Bank of Canada, says curtailment of credit has been forced on chartered banks by tight money coupled with the $6 \%$ legal ceiling on the lending rates of chartered banks (New York Times, 1959, p. 45).

As a result, the Royal quickly dropped from a 33\% share of the mortgage market in 1958 to $0.2 \%$ in 1961 . Without the flexible interest rates enjoyed by the near-banks, the chartered banks were unable to realize profits in mortgage lending. In the context of increased competition, the chartered banks responded by moving "aggressively into the short-term money market" (McDowall, 1993, p. 333) and by expanding internationally. ${ }^{103}$

Since international banking was unregulated by the Bank Act it offered the chartered banks a chance to escape the new constraints of domestic banking (the $6 \%$ ceiling

102 Interestingly, the federal government had been trying to get the chartered banks to provide mortgage loans since the late 1940s. The Canada Mortgage and Housing Corporation (CMHC) was a crown corporation created in 1946 to regulate National Housing Act loans, but since trust and insurance companies were only permitted to loan up to the extent of their paid-in capital, the housing industry soon found itself in crisis. With the post-war baby boom in full swing, the federal government stepped in and tried to convince the chartered banks to provide housing loans. The Royal initially balked at the suggestion, but would end up sending their future president, W. Earle McLaughlin, to Ottawa to study whether mortgage lending would leave them short of liquidity.

103 As Lapavitsas (2013) notes, short-term money markets emerged as a result of the demand for liquidity in the normal course of banking: "supply of loanable capital in the money market emerges as banks find it expensive to hold spare liquidity; demand comes from banks seeking to borrow liquidity to fund assets" (p. 131). Competition from the near-banks led the chartered banks to start pressuring the Bank of Canada for such a market as early as 1954. The Royal's president, James Muir, would make his case for a Canadian money market on the grounds that such markets were "a symbol of economic maturity and strength," as well as a prerequisite to progress, especially for a "country like Canada whose economic future depends on the expansion of world trade and investment" (Globe and Mail, 1954, p. 22). In reality, they were simply a means of growth in the absence of other profitable investments. 
on loan interest, for example, did not exist abroad); as a result, the Royal's foreign assets started to grow at a pace that "far outstripped growth of their domestic assets" (McDowall, 1993, p. 343). Their first major expansion during this period was, like before, into the Caribbean and Latin America. Branches grew from 61 in 1950 to 101 by the end of the decade; and by 1960, the Royal's 27 South American branches made them dominant over all other Canadian banks on the continent. As they reached deeper and deeper into Latin America, the Royal used their corporate power to transform the very laws of the countries in which they operated, making them more beneficial for foreign capital. Indeed, as McDowall (1993) notes, the Royal cared little whether dictators in Haiti, the Dominican Republic, or Cuba "treated their local economies as fiefdoms" (p. 343). They, like the other Canadian banks, saw the region as one made up not of individual countries, but as "a single area where they do business" (Baum, 1974, p. 53).

A good example of this is Jamaica. After finishing his tenure as the governor of the Bank of Canada (1934-1954) and alternate governor of the IMF (1946-1954), former Royal executive Graham Towers was asked by the Jamaican government to review the role of Jamaica's financial institutions and whether the country should create a central bank (Fullerton, 1986, p. 286). Officially appointed by the United Nations Technical Assistance Administration and in consult with the Bank of Canada and Canadian Ministry of Finance, Towers' report made a number of suggestions that would ultimately restrict "the range and action of political authorities while giving (foreign) bankers more freedom" (Deneault, 2015, p. 36). The creation of a central bank in Jamaica, for instance, was rejected by Towers on the basis that monetary independence might lead to "inflation, 
instability, and retardation of development" (as cited in Deneault, 2015, p. 36). This is despite the fact that Canada had created their own central bank only 15 years earlier with no ill effects. Towers also argued that the creation of a central bank was unnecessary since Jamaica had the "wholehearted co-operation of existing banks" (p. 36) of which, three out of four were Canadian, including the Royal. Further 'offshore' legislation came with the creation of the International Business Company (IBC) in 1956. As Deneault (2015) explains, the IBC allowed companies or shareholders registered in Jamaica to receive funds from abroad without paying taxes; it was "the first step in a process that has lead to the transformation of almost every territory in the British Caribbean into an offshore jurisdiction" (p. 37). Similarly, Sir Stafford, the finance minister of the Bahamas, became a director for the Royal in 1966. Two years earlier, he had written a book detailing how Americans could avoid taxes by setting up shop in the Bahamas. He is often credited as the principal architect of the Bahamian tax haven (Chodos, 1977).

As a reaction to these policies and the devastating economic conditions that resulted from their implementation, Jamaica achieved self-government in 1959. Other colonies would soon follow, spurred on by a more general anti-colonial movement against the power of foreign banks. In Trinidad, for example, C.L.R. James would lament that "Independence Square is surrounded by some of the most magnificent buildings in the territory and all of them are foreign banks. That's how we live. They rule the place" (Hudson, 2010, p. 35). James was right, of course. Canadian banks controlled 60\% of Trinidad's commercial and retail banking. Similarly, after six decades in Cuba, the Cuban Revolution forced the Royal to sell their Cuban assets. While they continued to 
finance Cuban trade, Castro nationalized all but two foreign banks in 1965, effectively ending the Royal's dominance of Cuban banking; however, although the bank was nationalized, it was still "permitted to withdraw its capital stock," which was, as reported by the New York Times (1960) "the first time that a foreign bank has been permitted by the Cuban Government to withdraw its capital stock. All other banks were nationalized without any compensation to their stockholders" (p. 34). As McDowall (1993) notes, the Bay of Pigs "provided a kind of symbolic sawn song for the bank's retail system in the Caribbean and Latin America" (p. 365). Despite attempts to localize branches by dropping Canada from the name, the overall trend in the 1960s was a gradual disinvestment from the region, punctuated by the occupation of the Royal's Trinidadian branch by the National Joint Action Committee on February 26, 1970. As Hudson (2010) notes, the Royal was not seen as "an innocent agent of a goodly and innocuous developmentalism, but a symbol of a rapacious imperialism" (p. 35). Indeed, the Royal had been bombed in Cuba as early in 1931: "the authorities are redoubling their efforts to apprehend the bomb throwers, who have been carrying on a campaign of terror since the beginning of the recent revolutionary movement" (New York Times, 1931, p. 8).

The Royal grew elsewhere, however, through their links to large multinational corporations (MNCs). As a by-product of their earlier 'industrialization by solicitation' strategy, the Royal was already well connected to American MNCs and, as such, "prominent American accounts—First Boston, US Steel, and Merrill Lynch—-began appearing in the loan approvals. In 1957, for instance, the bank provided financial support for Aristotle Onassis' shipping activities and the Gulbenkian Middle-Eastern oil empire" (Mc- 
Dowall, 1993, p. 341). They also moved (like they had earlier in Canada) into regions of the world where industrialization was just emerging, such as in Dallas, where a representative was posted in 1958 to capture American oil interests, or in China, which was rapidly trying to "surpass the productive powers of the Western world" (James Muir as cited in McDowall, 1993, p. 346). These moves were aided by the World Bank, which provided the world's largest banks with a number of assorted benefits, such as the ability to profit from third-world development projects. In 1957, for example, the World Bank provided a $\$ 40$ million loan to the government of the Belgian Congo (now the Democratic Republic of the Congo) for a highway building program. As Park and Park (1962) note, the loan was not so much a 'do good' operation, but rather, a means to enrich the Belgian firms connected with the Royal. Their international efforts were so successful that by 1960 , the Royal, the Bank of Montreal, and the Canadian Imperial Bank of Commerce (CIBC) ranked among the 12 largest banks in the world, with the Bank of Nova Scotia and the Toronto-Dominion Bank (TD) trailing just behind: "combined these five banks held 15\% of the international market" (Darroch, 1992, p. 153).

That Canada's chartered banks could be so successful in this context demonstrates the extent to which the restrictions of Bretton Woods helped protect national capitals from external forces. It did not help them from internal forces, however, since this system also helped foster an increase in domestic competition that eventually forced the banks to escape national regulation by increasing their level of international activity. The problem, however, was that this business was still subject to and limited by the regulations of the host country; further still, their domestic banking activities remained highly regulated. In 
order to grow large enough to vanquish their domestic competition, the chartered banks required a territory absent of regulations that would allow them to overcome the existing limits to accumulation. They would find this territory with the creation of the Eurodollar markets. ${ }^{104}$

\subsection{The Eurodollar Markets}

As political scientist Eric Helleiner (1994) notes: "in supporting the creation and growth of the Eurodollar market[s] . . . the United States and Britain encouraged the first decisive shift away from the restrictive Bretton Woods financial order” (p. 99). The essence of the Eurodollar markets is captured by Robinson (2004) when he writes that through it, "money goes global" (p. 111). The Eurodollar markets were more or less unregulated territories for accumulation that were formed in 1957 after the Bank of England decided not to regulate any "transactions taking place in dollars if they were carried out by two non-residents" (Deneault, 2015, p. 32). While the creation of the Eurodollar markets was in some sense a means of helping the City regain some of its former glory as the centre of international finance, it was also a reflection of the success of the Bretton Woods system in restricting transnational flows of capital. ${ }^{105}$ As Porter (2005) notes, the

104 Sassen (2006) speaks to this as a more general phenomenon in the American context: "Some of the problematic outcomes in the 1970s for the United States were a result of the economic growth in the 1950s and 1960s. That growth led U.S. banks and financial investors to search for ways to get around the walls built into the banking and financial sectors to protect them from the types of reverberations that had characterized the 1929 stock market crash. This search contributed to the formation of the offshore markets" (p. 167).

105 I use transnational here instead of international, because the Bretton Woods system was highly successful in promoting international economic activity; that is, economic activity that operates within and between, rather than across, the borders of countries. For more details, including a visual representation, see Robinson's (2004) explanation of the differences between an international and global world economy. 
Eurodollar markets provided a way for "the most internationally active firms to circumvent these restrictions without requiring governments to dismantle them" (p. 18). As corporations extended their reach around the world, they were able to evade domestic capital controls by simply "depositing their capital in foreign currency markets" (Robinson, 2004, p. 111). In other words, they did not send the dollars back home, but deposited them instead as 'Eurodollars' in third-country banks. The end result was a massive spread of unregulated American dollars and other core country currencies around the world that large banks subsequently used to provide short- and medium-term loans. The significance is noted by Porter (2005) who writes that: "the present period of financial globalization . . . began with the Eurodollar markets" (p. 51).

Interestingly, in their competition with the near-banks, the Royal actually helped "pioneer the Eurodollar market by taking U.S. dollar deposits from the Moscow Narodny Bank in Toronto" (McDowall, 1993, p. 407). After returning from a trip to Russia to promote trade in the mid-1950s, the Royal's president noted that the Russians were "anxious to trade with any country, and that 'it is in Canada's interest to promote trade wherever she can" (James Muir as cited in Globe and Mail, 1956, p. 12). Regulation Q of the United States Federal Reserve Act had put an artificially low ceiling on interest gained in New York on offshore deposits, meaning that the Russians required somewhere else to invest their U.S. dollars; offshore deposits made in Eurodollars in Toronto offered a much higher rate of return. As the deposits of these Eurodollars grew larger and larger, the Royal saw the potential profits to be made by using them to provide loans to MNCs and na- 
tional governments. As the international market for short- and medium-term loans began to grow, so too did the size of the chartered banks.

The Eurodollar markets were a huge boost for capital during this period because they were unconstrained by national regulations or political pressures. Indeed, Hayes and Hubbard (1990) have described them as "the first marketplace without a home base" (p. 27). The sums involved in the Eurodollar markets were in fact so large that they actually embarrassed the world's banks, who were forced to use an 'offshore discretion' to keep them hidden from the public (Deneault, 2015, p. 32). Internationally, Eurodollar deposits ballooned from just $\$ 3$ billion (U.S.) in 1960 to $\$ 75$ billion in 1970. Here again, Canada’s chartered banks played a crucial role, transforming "the Caribbean into a vector for Eurodollars and illicit transactions, thus launching the great project of moving the entire world offshore" (p. 33). Later, near the end of his term, the Royal's president, W. Earle McLaughlin, remarked that the Eurodollar was "a pretty good invention. I don't know what we would do without it" (as cited in McDowall, 1993, p. 407). Indeed, by the end of the 1950s alone, the Royal's $\$ 4.3$ billion in assets represented "a quarter of the whole industry's assets” (p. 326).

With Eurodollar profits booming, the chartered banks were finally able to wipe out their domestic competition. Given both the changing nature of the financial sector, as well as the rising competition between the near- and chartered banks, Prime Minister Diefenbaker asked Dana Porter, Chief Justice of Ontario, to lead the Royal Commission on Banking and Finance (the Porter Report) in 1961. Using the language of justice and fairness, the chartered banks argued that the near-banks should actually be left alone, and 
that instead, similar rights and freedoms should be extended to the chartered banks. When the Porter Report (1964) suggested that trust companies should have all the freedoms and responsibilities of the chartered banks, the Royal's McLaughlin responded by arguing the opposite: "that the area of competition should be widened by allowing the chartered banks to do trust company business" (as cited in Globe and Mail, 1964, p. 6). Similarly, when it was proposed that the chartered banks be prohibited from owning more than $10 \%$ of the stock of another company (Canada, 1964, p. 563), McLaughlin responded by asking whether "non-banking financial institutions or non-financial institutions be completely free to invest in, own, or control any banking institutions?" (p. 6). A simpler statement of the Royal's position is found in their 1966 annual report:

Competitive balance and the efficiency of monetary policy can best be achieved by leaving the near-banks alone, and extending to the banks the freedom now enjoyed by the near-banks. This is far superior to the alternative of shackling the near-banks with legal cash-ratio requirements and interest ceilings. It is better to extend freedom than to proliferate controls (p. 15).

When the dust finally settled in 1967, the revisions to the Bank Act were effectively a coup for the chartered banks. While they were now prohibited from owning trust companies (thus ending the Royal's affiliation with Montreal Trust) the Act also removed the $6 \%$ ceiling on loans, lowered cash reserve requirements, and eliminated restrictions on the banks' involvement in mortgage financing (Freedman, 1998). "Praised by bankers as being 'market-freeing,"' (McDowall, 1993, p. 357) the revised Bank Act quickly trans- 
formed the chartered banks into producers of consumers credit: "diversified retail financial services for the man of ordinary means" (Neufeld, 1972, p. 134). With Chargex (now Visa) cards, mutual funds, consumer loans, and electronic banking beginning to figure into the financial calculations of the average Canadian, the chartered banks began to see the spread between their bank deposits and loan rates widen. As Whittington (1999) notes: "in just one year, the Royal Bank recorded $\$ 50$ million in credit-card transactions" (p. 28). Indeed, as noted in the later Royal Commission on Corporate Concentration (1978):

After the 1967 revision of the Bank Act the profitability of the chartered banks increased quite substantially as of course was expected. The 1976 Economic Council of Canada study shows an increase in the after-tax rate of return on equity of the seven largest banks from an average of $8.1 \%$ in the $1963-67$ period to $12.9 \%$ in $1968-73$. The study notes that this latter figure is higher than that for all U.S. insured banks in the same period (p. 226).

As their profits increased, the chartered banks' profit rate would start to run consistently above those of their main rival institutions, the near-banks, allowing them to double "their rate of asset expansion within a single decade" (Newman, 1979, p. 136). As such, the near-banks were no longer a competitive threat to the big banks - a reality that is still the case today.

The near-banks were not the chartered banks only domestic competition, however. Arriving in 1963 with Citibank's purchase of the Mercantile Bank of Canada (a decadeold, Dutch-owned trade bank), the federal government had become increasingly con- 
cerned about the possibility of an American takeover of the chartered banks. In response, the Minister of Finance immediately imposed limits on foreign ownership, forbidding any single shareholder from holding more than a $10 \%$ stake, with aggregate foreign ownership capped at 25\% (Morck et al., 2007, p. 134). There was, of course, a certain irony to the fact that in the 1960s, while the government was fast-acting in protecting the banks from a possible foreign takeover, that the banks were themselves advertising their services as a broker in Canadian firms:

Not just where insolvency necessitated bank participation in the process of finding a purchaser and reorganizing debt; but anywhere where the security of the banking business to be done might be increased by a larger (multinational) firm taking over a smaller one (Quigley, 1986, p. 37).

Like the near-bank issue, debate over the matter of foreign ownership consumed the late 1960s, with the Royal's president, W. Earle McLaughlin, arguing, like before, for 'openness' and 'freedom': "is it reasonable for Canadian institutions to expect to participate in world markets while we deny foreign institutions access to ours?" (Royal Bank of Canada, 1966, p. 16). McLaughlin's position was one based on the rising strength of the chartered banks which, if left alone to freely compete against domestic competitors, would easily be able to crush them: "I find it difficult to accept the premise that no new offices of foreign banks can be tolerated or that further growth of the one very small foreignowned bank already here would be a threat to the 'Canadian context' of our banking system" (p. 16). In spite of McLaughlin's argument that "banking legislation should substitute free competition for regulation wherever possible" (p. 11) the restrictions on foreign 
ownership did little to stop foreign banks from actually operating in Canada: "by securing provincial incorporation and posing as non-bank intermediaries" (Naylor, 1985, p. 138) foreign banks could operate in Canada without reserve requirements and within many of those fields that the chartered banks were still barred from entering. "Disenchanted with the government's policies discouraging foreign investment and the inability to control the deficit," the chartered banks would complain that Canada was "not being run in a very business-like fashion" (Darroch, 1992, p. 164). As such, the Royal would increasingly focus on their business abroad where they were unregulated by the Bank Act and did not "have to hold cash or liquidity reserves against foreign-currency deposits" (Canada, 1978, p. 232).

The Royal's increasing focus on their international business was not merely a reflection of the vast sums being made; by the 1970s, the concept of the head office had more or less been eroded in strategic terms as a result of electronic communications and jet travel. For their part, the Royal now possessed departments in 14 cities around the world that canvassed for regional business (Quigley, 1986, p. 37), and further expansion to the United States saw offices spring up in San Fransisco, Denver, Houston, Pittsburgh, Miami, Dallas, Los Angeles, and Chicago. They also opened offices in Beirut, Cairo, Dubai, Athens, and Bahrain. From 1965 to 1980, Canada's chartered banks acquired "in whole or in part more than 160 primary foreign banks and companies" (Darroch, 1992, p. 162) (see Table 6). The end result of their international expansion was that by 1966 , both the Royal and the Commerce were counted among the world's top 20 banks (Globe and Mail, 1966, p. B1). It is thus no surprise that later, in 1972, the Federal Report on Foreign 
Direct Investment referred to the chartered banks as "global corporations" (Baum, 1974, p. 5). The vast flows of money capital created by the Eurodollar markets, however, would soon overwhelm the fixed exchange rates and capital controls of the Bretton Woods system. In doing so, they would not only lead to its collapse, but act as the tipping point into our present global epoch.

Table 6

Branches of Canadian Chartered Banks Outside Canada, 1967

\begin{tabular}{|l|l|l|}
\hline Bank & Location & Number \\
\hline Bank of Montreal & Britain & 2 \\
& United States & 3 \\
& Germany & 6 \\
\hline Bank of Nova Scotia & Antigua & 1 \\
& Bahamas & 5 \\
& Grenada & 1 \\
& Trinidad & 7 \\
& Barbados & 3 \\
& Dominican Republic & 3 \\
& England & 3 \\
& Scotland & 1 \\
& St. Lucia & 1 \\
& Puerto Rico & 3 \\
& U.S. Virgin Islands & 4 \\
& United States & 1 \\
& Lebanon & 1 \\
& Netherlands & 1 \\
& Ireland & 1 \\
British Virgin Islands & 1 \\
Belgium & 1 \\
\hline
\end{tabular}


Branches of Canadian Chartered Banks Outside Canada, 1967

\begin{tabular}{|c|c|c|}
\hline Canadian Imperial Bank of & Britain & 2 \\
\hline Commerce & United States & 11 \\
\hline & Antigua & 1 \\
\hline & Bahamas & 3 \\
\hline & Barbados & 1 \\
\hline & Cayman Islands & 1 \\
\hline & Grenada & 1 \\
\hline & Jamaica & 8 \\
\hline & St. Vincent & 1 \\
\hline & Trinidad & 5 \\
\hline Royal Bank of Canada & Argentina & 2 \\
\hline & Bahamas & 6 \\
\hline & Brazil & 3 \\
\hline & British Honduras & 4 \\
\hline & Cayman Islands & 1 \\
\hline & Colombia & 5 \\
\hline & Dominican Republic & 11 \\
\hline & France & 1 \\
\hline & French West Indies & 2 \\
\hline & Britain & 2 \\
\hline & Guyana & 6 \\
\hline & Haiti & 1 \\
\hline & Jamaica & 11 \\
\hline & Peru & 1 \\
\hline & Puerto Rico & 6 \\
\hline & Trinidad & 11 \\
\hline & Tobago & 1 \\
\hline & United States & 1 \\
\hline & Venezuela & 6 \\
\hline & West Indies & 11 \\
\hline Toronto-Dominion Bank & Britain & 2 \\
\hline & United States & 1 \\
\hline Banque Canadienne Nationale & France & 1 \\
\hline
\end{tabular}

Note. Reprinted from Canada Year Book, by Statistics Canada, 1967.

\subsection{The Collapse of Bretton Woods}

The Royal's international growth was a reflection of the circumstances of the day.

There was a dialectical relationship between the rise of the Eurodollar markets on the one 
hand, and the growth of multinational corporate activity on the other. As Henwood (1998)

notes: "production must be financed, and if all goes well, it throws off profits in money form, and globalized production is no exception, meaning that MNCs inevitably create financial flows alongside their productive activities" (p. 112). ${ }^{106}$ As noted by the earlier Royal Commission on Corporate Concentration (1978):

During the past 10 years the nature of [the chartered banks'] international operations has changed dramatically. In the late 1960s, Canadian banks began a major expansion of their international activities, largely as a result of the rise of the Eurodollar market and multinational corporations. Banks have expanded from overseas branches and agencies to include representative offices, foreign affiliates and subsidiaries (p. 232).

As multinational corporate activity required ever-greater sums of capital to expand, it meant that financial institutions were increasingly in possession of ever-greater sums of foreign currency. As a result, Eurodollar deposits around the world ballooned from just $\$ 3$ billion (U.S.) in 1960 to $\$ 75$ billion in 1970 before climbing to well over $\$ 1$ trillion by 1984 (Robinson, 2004, p. 111). The foreign-currency assets of Canada's chartered banks had amounted to only $25.1 \%$ of their Canadian assets in 1966 , whereas by 1976 , they were up to $42.4 \%$ (Canada, 1978, p. 232). These immense flows of money capital were fundamentally in contradiction with the fixed exchange rates and capital controls of the Bretton Woods system, making "it all but impossible to carry out orderly adjustments of

106 As Stephen Hymer (1979) put it at the time: “The multinational corporation's need for short-term loans and investment arising from the continuous inflow and outflow of money from all nations, never quite in balance, has encouraged international banking and has helped integrate short-term money markets; its long-term financial requirements . . have broadened the demand for international bond and equity capital" (p. 82). 
currency pegs" (Eichengreen, 1996/2008, p. 2). This was further frustrated in Canada by a 1963 agreement with the United States that put a ceiling of $\$ 2.55$ billion on reserves of foreign currencies. Finding it difficult to carry out currency adjustments in such a context, the Canadian government followed the advice of the chartered banks and unpegged the currency in $1970 .{ }^{107}$ Amid their own dollar crisis, the United States would do the same in 1971. ${ }^{108}$ While there were some attempts to patch the system together, most currencies started floating, one by one, in 1973. Their value was now set by trading on a vast international marketplace.

The collapse of Bretton Woods had both immediate and long-term consequences.

The first was more or less the end of the welfare state. While many welfare programs would remain (and still remain with us today, albeit in altered or reduced form) the flows of international currency initiated by the Eurodollar markets and the subsequent collapse

107 Having only pegged the currency to the U.S. dollar in 1962, the Royal suggested unpegging it as early as 1968: "Mr. McLaughlin told the bank's 99th annual shareholders' meeting that unprecedented arrangements concluded with the United States in recent years have placed Canadian monetary policy in an intolerable squeeze. On one hand, the growth of Canada's vital reserves of foreign currencies was blocked by a ceiling of $\$ 2.55$-billion imposed by Finance Minister Mitchell Sharp last May under a 1963 agreement with the United States. On the other hand, the Canadian dollar's value abroad could not grow because the exchange rate was pegged at 92.5 cents in U.S. currency in 1962 . The ideal solution to combat Canada's dangerous inflation would be to restore the floating dollar exchange rate that prevailed before 1962" (Lebel, 1968, p. B3). For more on Canada's general experience with the collapse of the Bretton Woods system, see Soederberg (2000).

108 Henwood (1998) provides more detail: "From soon after the war was over until today, the U.S. has acted as the final source of world demand. There was the Marshall Plan, global military expansion, investment abroad by newly globalizing U.S. multinationals, and always more and more imports - all of which scattered dollars around the world. That cascade of greenbacks, plus rising domestic inflation, meant that the dollar was no longer worth as much as it was supposed to be - that is, the gold price was artificially low-and that cashing in dollars for gold at posted prices was a marvellous deal. (No one took more pleasure in pointing this out than Charles de Gaulle.) Strains began appearing in the system in the late 1960s; the outflow of gold from the U.S. to London was so great during the week of the Tet Offensive in Vietnam (March 1968) that the floor of the Bank of England's weighing room collapsed. The German mark broke free and appreciated in 1969, and repeated the break out in 1971. The French cashed in dollars for gold, and there were rumours that Britain was next. So in August 1971, Nixon closed the Treasury's gold window, ending the sale of cheap gold" (pp. 43-44). For more on the American context, see Konings (2011) and Panitch and Gindin (2012). 
of the Bretton Woods system eventually overwhelmed the ability of capitalist nationstates to be managed by governments as a relatively self-contained unit. As such, these nation-states became increasingly reoriented toward the integration of the domestic economy into the larger global economy by enhancing the domestic economy's competitiveness through neoliberal reforms that often included the privatization of social programs, the driving down of domestic wages, and the reduction of inflation (Bienefeld, 1992; Harvey, 2005; Teeple, 2000). While these reforms took place in a relatively uneven or variegated manner across the capitalist nation-states of the world (Brenner et al., 2010), the emergence of neoliberal policy was itself a reflection of the growing power of financial capital, since the existence of "very diverse inflation levels across the world was extremely problematic for the growth of a global financial market" (Sassen, 2014b, p. 3). Furthermore, as money capital gained the capability to move more freely around the world, the ability of the nation-state to control and tax capital declined substantially; the period after the collapse of the Bretton Woods system has thus seen a massive growth in household and state indebtedness (a process discussed in the next chapter) that is presently reaching crisis levels (Graeber, 2011; Lapavitsas, 2013; Lazzarato, 2012; Marazzi, 2010).

The dismantling of Bretton Woods also produced a number of effects related to banking and finance more specifically. As Germain (2010) notes, the collapse can account for turbulent foreign exchange fluctuations, a deep international debt crisis involving developing countries, spectacular growth of financial markets, the internationalization of banking networks from many countries, dramatic reversals 
in the international accounts of major debtor and creditor countries, the

emergence among these countries of significant balance of payments imbalances,

and several currency and banking crises (p. 56).

As a partial result of these various events, nation-states began to coordinate more closer in respect to monetary cooperation, a process that ultimately led to the construction of the European Union (EU) and the Euro, as well as the Group of Seven (G7), an organization that attempts to foster similar macroeconomic policies among the world's wealthiest countries. ${ }^{109}$ While the $\mathrm{G} 7$ does not involve any new governing rights or powers, it is in a certain sense an embryonic transnational authority that works to determine the 'proper' or 'best' means for national governments to manage their national economies (i.e., national systems of property relations) within an emerging system of global capitalism. In the years following the collapse of Bretton Woods many other similar institutions have emerged for roughly the same purpose, to coordinate national political responses to what are more or less global economic problems. This has also included the reorientation of pre-existing supranational institutions such as the IMF, the WB, and the Bank of International Settlements (BIS), which have all taken on new roles. ${ }^{110}$ What is especially significant about these supranational institutions is that many of the rules generated by them eventually become made into law by governments, meaning that unlike the national

109 The G7's precursor, the G5, was created in 1974, and consisted an informal meeting of the finance ministers and central bank governors of France, West Germany, Japan, the United Kingdom, and the United States. A year later, the G6 was created with the inclusion of Italy. Canada became the seventh member country to join the meetings in 1976. The criteria for membership is a high net national wealth and a very high human development index.

110 While these institutions could be considered international in the sense that that their existence is the result of agreements between many nations, I use the term supranational since they have power and influence that sometimes transcends national boundaries and governments, even if it is not codified. 
epoch, there has been a shift in authority away from the nation-state toward what are essentially private institutions (e.g., Cutler, 2011; McBride, 2011). To put it simply, public authority "is no longer exclusively state-led. It is now involved in a compact with private authority, where a balance between competing institutional forms anchors authority" (Germain, 2010, p. 76). As Sassen (2006) notes, the primary aim of these new forms of private authority "is to set up a global system for governing trade, capital, services, and information flows through intergovernmental agreements on critical requirements such as financial reporting standards, the private property rights regime, or the global trading agreement” (p. 195).

The third and perhaps most significant consequence of the collapse of Bretton Woods has been: "the liberation of embryonic transnational capital from the institutional constraints of the nation-state system" (Robinson, 2004, p. 111). The collapse set off what many have come to call financial globalization, the freedom of money capital to fly around the world at breakneck speeds looking for profitable avenues for investment. Indeed, as Germain (2010) notes: "since 1974, when Richard Nixon began the process of reversing controls on the freedom of movement of capital, country after country has followed suit, and now we live in a world of almost full capital mobility" (p. 54). As we have seen, the collapse of Bretton Woods was caused by growing national banks attempting to evade the regulatory powers of the nation-state by accumulating liquid capital in offshore markets. In the following chapter, I discuss a number of the consequences of this shift in more detail, but for now, we can note two significant transformations: (1) the deregulation of the banking and finance sectors in capitalist countries around the world, a 
process which actually involves the removal of national constraints to their accumulation activities - mainly the removal of the legislated divisions between the various domains of finance (banking, trust, insurance, investment, and so on); and (2) so-called free trade agreements that involve the creation of large regional markets that not only reorient the role of the nation-state toward the protection of the rights of foreign capital, but also grant capital new rights to sue national governments in private courts for policy decisions that impact their accumulation activities. I claim that this reorientation is transforming the role of the nation-state into a capability for globalizing capitals and should be understood more broadly as part of the construction of a global system of property relations; that is, an emerging global system of rights for capital enforced by nation-states. To me, this process not only provides empirical substance to claims that a transnational state is emerging, but demonstrates the extent to which we should understand globalization as a novel epoch within the history of capitalism. The details of these transformations will be provided in the next chapter, while many of their implications — of which there are many —will be dealt with in the final two chapters. 
Table 7

Global Ranking of Canadian Banks, 1970-2000 (position among the world's banks, ranked by assets)

\begin{tabular}{|l|l|l|l|l|l|l|l|}
\hline & $\mathbf{1 9 7 0}$ & $\mathbf{1 9 7 5}$ & $\mathbf{1 9 8 0}$ & $\mathbf{1 9 8 5}$ & $\mathbf{1 9 9 0}$ & $\mathbf{1 9 9 5}$ & $\mathbf{2 0 0 0}$ \\
\hline RBC & 10 & 22 & 23 & 32 & 51 & 61 & 53 \\
CIBC & 13 & 29 & 36 & 46 & 58 & 62 & 58 \\
BMO & 25 & 45 & 50 & 40 & 76 & 72 & 63 \\
Scotiabank & 43 & 53 & 55 & 60 & 81 & 76 & 62 \\
TD & 56 & 66 & 71 & 75 & 113 & 100 & 59 \\
\hline
\end{tabular}

Note. Reprinted from The Banker, various years.

\subsection{Conclusion}

Against the view that this period represents the beginnings of globalization, this chapter set out to explain why we should see it instead as a continuation of the national epoch of capitalism. I made this argument on the basis that despite an increase in international economic activity and multilateralism, the period was still primarily constituted by national systems of property relations; that is, by national assemblages of TAR. As such, the capitalist nation-state continued to function as a capability for the growth of domestic capitals, despite an increase in international economic activity and coordination. It did this by not only protecting the basic rights of private property necessary for the domestic market to function, but also by restricting the rights of foreign capitals within that territory and by participating to a much larger degree within the national economy. While these measures were extremely successful in growing national capitals, this growth would also force the transformation of those elements of TAR that restricted capital's more general expansion. 
To demonstrate the empirical reality of this characterization, I provided an analysis of the transformation of Canadian banking via the history of the Royal Bank of Canada from 1940 to 1974. I identified the Bretton Woods system as a continuation of the centripetal organizing dynamic of TAR on the basis that it did not require nation-states to relinquish their authority to manage or participate within the national economy, but actually strengthened their ability to do so. Through the construction of a relatively closed national economy by virtue of foreign exchange and capital controls that restricted the capacity of financial capital to flow unimpeded around the world, I argued that the Bretton Woods system led to an increase in domestic competition amongst the chartered banks from smaller finance and trust companies that were unconstrained by the restrictions of the Bank Act. This struggle, in turn, led the Royal, along with the other chartered banks, to expand via the Eurodollar markets in order to escape national regulatory control. While this enabled them to grow extremely large (crushing their near-bank rivals in the process), the massive flows of foreign currency generated by the Eurodollar markets eventually overturned the Bretton Woods system. I concluded by highlighting some of the reasons why we should understand the collapse of this system as the tipping point into our current global epoch, as well as some of the consequences for banking and finance. As I discuss in the next chapter, if the earlier period of capitalist development can be understood as the making of national capital, then we should consider the period from 1975 to 2014 as the making of global capital; that is, as the construction of a global system of property relations, despite the persistence and importance of the nation-state to this system. 


\section{Making Global Capital: RBC in the Digital Age, 1975-2014}

We used to be a large Canadian bank with international interests. But now we are a large international bank with a strong Canadian base. There's a difference.

- Rowland Frazee, CEO of the Royal Bank of Canada, 1980.

\subsection{Introduction}

In the last chapter, I explored how the period from the 1940 until 1974 was constituted in its configuration of territory, authority, and rights (TAR) in respect to Canada's chartered banks. I argued that we should understand that period as the interregnum between the national and global epochs within the history of capitalism on the basis that it began with a continuation of the centripetal dynamic of TAR which characterized the earlier period of capitalism, as examined in chapter three. I made that argument on the basis that despite an increase in international economic activity and new forms of multilateralism, the period was still based on national systems of property relations; that is, by national assemblages of TAR. Under this type of assemblage, the institutional structure of the capitalist nation-state primarily operated as a capability for their own capitals by protecting the basic rights of private property necessary for the domestic market to function and by sometimes restricting the rights of foreign capitals within that territory. In other words, since the rights of capital remained at the nation-state level, national governments were able to restrict these rights if they significantly impeded the development of the national political economy. In such a context, the ability to do so rested primarily on the strength, nature, and character of the domestic ruling class. As such, the national epoch of 
capitalism was one in which the conceptual framework of theories of imperialism and dependency roughly held true: the world was made up of nation-states that typically acted on behalf of their national capitals.

In this chapter, I continue our analysis by focusing on those shifting elements of TAR that now problematize that interpretation of the global political economy. In particular, I explore an emerging centrifugal dynamic that stands in stark contrast to the organizing logic of the national epoch of capitalism. Instead of asking whether Canada is a secondary imperialist power or a rich dependency, I ask how these shifts fundamentally restructure the global political economy; in particular, the various ways in which they reflect an "incipient, highly specialized and partial denationalization of specific components of national states" (Sassen, 2003, p. 4). The effort is thus double-sided. On the one hand, I want to distance myself from the idea (as it exists in theories of imperialism and dependency) that since the nation-state is still here that it works more or less as it always has; that is, within a competitive interstate framework in which nation-states act on behalf of their national capitals. On the other hand, I also want to escape from what Sassen (2006) refers to as the 'endogeneity trap,' the tendency to confine the study of globalization to explicitly global processes and institutions. As she notes, simply pointing to the "features of the global amounts to a description but not an explanation of globalization" (p. 4). ${ }^{111}$ By focusing on the denationalization of specific elements of TAR that may still be 'located' at the national level, my effort is to understand how and why an

111 Similarly, pointing to the features of national institutions or processes do not make them necessarily national; in other words, just because something is nominally national does not mean that it necessarily supports a national organizing dynamic. The nation-state being the most prominent example. 
existing assemblage of TAR can become reoriented toward an altogether different organizing logic; that is, how capabilities, such as the nation-state, are able to jump tracks and become a key site for the support and development of globalizing capital. In my view, the emerging centrifugal dynamic of TAR gives us a small glimpse of a much larger transformation: the construction of a truly global system of rights for capital outside the grasp of national politics.

I identify three shifts in TAR - the movement of the authority over banking to supranational institutions, financial deregulation, and so-called free trade agreements- to represent this centrifugal dynamic as it relates to Canada's chartered banks. What has been the result of this new organizing logic? To provide globalizing capitals (including what were formerly national capitals) with the capability to grow and expand by restricting the powers of the nation-state to legislate against anything that might impact their accumulation of capital.

The chapter proceeds as follows. First, I provide a brief discussion on how much of what falls under the label globalization refers to the reorientation of national institutions and processes. Next, I focus on each of the shifts in TAR noted above and explore their effects on the Royal Bank of Canada's operations and activities. Special attention is paid to the specific nature of conflicts between the Royal, the other chartered banks, and the federal government. I argue that these shifts in TAR are representative of the growth of capital past the institutional confines of a national system of property relations. As such, I conclude that we should understand our present period as a new historical epoch that consists of the making of global capital. 


\subsection{Reorienting Supranational Institutions}

Up to this point, I have been concerned with demonstrating that, in respect to capital, Canada's earlier epoch of capitalism was characterized by a centripetal organizing dynamic in which territory, authority, and rights (TAR) were continuously drawn in toward the national level; in other words, the period was predominantly, insofar as capital was concerned, about constructing a national system of property relations (national systems of rights for capital governed by nation-states). In contrast, since the collapse of the Bretton Woods System, much of the global political economy, including Canada, has been characterized by a centrifugal dynamic in which the rights of capital and the authority over those rights have increasingly been moved to the transnational level. As I argue, this movement constitutes the first step towards the construction of a global system of property relations, the characteristic feature of our age.

My argument is based on the fact that after the collapse of Bretton Woods system, many new and pre-existing supranational institutions began to not only take on increased responsibilities relating to the regulation and reproduction of capitalism but, in doing so, actually started to restrict the capacity of nation-states to legislate against corporate interests. In my view, this process is far more significant than Canadian theories of imperialism and dependency recognize since it reduces the meaning of political rights within liberal democratic countries by reconfiguring their domestic laws. As Sassen (2006) notes, while "political nationalism may still prevail rhetorically," there are deep "structural tendencies that make international competition today function primarily as a mechanism for 
denationalizing capital" (p. 140). In other words, as nation-states compete for capital, they do so by changing or making rules that ultimately work to denationalize capital itself.

Some of these mechanisms are more legible than others, such as the structural adjustment policies pushed on developing nations by the International Monetary Fund (IMF) and the World Bank (WB) from the 1950s onwards. Less legible are those mechanisms that now restrict the capacities of advanced capitalist nation-states. If state building is the historical process through which certain groups are able to get the state to make rules that benefit their interests, then we should understand this shift as the result of the growth and expansion of capital to such an extent that it started to transform those national constraints that impeded the accumulation of capital. As McBride (2011) notes, this process was not "accompanied by the creation of a corresponding set of institutions to match the new accumulation regime. Instead, older multilateral institutions created during an era of embedded liberalism were reformed on an ad hoc basis" (p. 26). The reorientation of the Bank of International Settlements (BIS) is a good example of this more general phenomenon as it was "most important to Canadian central bankers" (Drainville, 1995, p. 17). Indeed, as Drainville (1995) notes: "if there was an institutional fulcrum of the 'shadow committee' in the monetarist period, this was certainly it" (p. 17). A brief examination of the changing role of the BIS over this period and its contribution to the growth of the Royal Bank of Canada will elicit some of the qualitative differences between the earlier national epoch of capitalism and our own. 
Originally established in the 1930s to facilitate reparations imposed on Germany after the First World War, the BIS really only got involved with the management of private banking after the collapse of the Bretton Woods System through the establishment of the Basel Committee on Banking Supervision (BCBS) in 1975. ${ }^{112}$ The BCBS was established by the central bank governors of the G10 countries and its purpose was to maintain monetary and financial stability in the new world of floating exchange rates. As Porter (2005) notes, the major concern of the G10 countries was that banks would simply "play one jurisdiction off against another, or move from one jurisdiction to another, in order to escape regulation" (p. 35). The BCBS attempted to solve this problem through a 1975 Concordat (revised in 1983 and 1992), which would make any bank's domestic regulator responsible for the regulation of their worldwide activities. Influenced heavily by monetarist thinking, which, contra Keynesianism, uses the money supply as the chief means of stabilizing the national economy, the BIS also began to pressure governments to reign in their spending, reduce their borrowings from the central bank (see Figure 2), and focus on

112 On the many roles of the BIS over time, see Strange (2015). 
reducing inflation. ${ }^{113}$ As Naylor (1987/1994) notes, the BIS was thus a means to "coordi-

nate policies for strangling global credit conditions and to plot the strengthening of the

political position of central banks vis-à-vis the governments they were supposed to serve"

(p. 338). It is not difficult to understand the historical fascination with reducing inflation,

since inflation reduces the value of financial assets, which, at this point, had become the

dominant form of wealth. ${ }^{114}$ Furthermore, varying levels of inflation among different

countries was, in general, "extremely problematic for the growth of a global financial

113 Monetarism is the name given to monetary policy influenced by neoliberal economics; roughly speaking, it uses the money supply as the primary means of stabilizing national economies. Helleiner (1994) notes that the monetarism promoted by the Bank of International Settlements was heavily influenced by neoliberal ideas, owing mainly to Per Jacobsson's role as the chief economic adviser to the BIS. Jacobsson was a prominent figure within the Freidreich Hayek-led Mont Pelerin Society, which Milton Friedman has described as a 'rallying point' for the neoliberal cause (p. 66-67). Monetarist thinking was thus promulgated through the use of the BIS (as well as other institutions, like the IMF) via regular meetings with central bankers to determine the 'rules of the game': 'the bank's statutes set for the basic principle that would guide the regime: encouragement of central bank cooperation for the purpose of maintaining global financial stability. They also established important decision-making procedures and rules of the regime, such as the requirements that the BIS Board of Directors meet at least ten times a year and that no government officials except central bank governors serve as directors, thus enhancing the board's independence ... The 1974 crisis encouraged a consolidation of this nascent regime with the establishment of the Basel committee and the rules concerning international, regulation, supervision, and lender-of-last resort activities" (pp. 174-175). Drainville (1995) also provides evidence demonstrating the extent to which Canadian central bankers were influenced by the BIS and monetarism in general during this period. He notes that: "from its inception, then, global monetarism was not about imposing a uniform path for money growth the world over; it was about coordinating and arranging different national monetarisms and fashioning a coherent international regime out of this varied patchwork" (p. 16). This occurred through two different types of institutions: "the first consisted of well-established meeting places of international policy making: the IMF, the Working Party 3 of the Organization of Economic Development (OECD), and the Bank of International Settlements. Of those institutions, the Bank of International Settlements (BIS) was perhaps most important to Canadian central bankers ... Technically an international clearing house for central banks that own it, the BIS also provided a secretariat for a variety of central bank gatherings. Above and beyond that, however, the importance of the BIS in the latter part of the 1970s lay in its status as a central bankers' private club, meeting ground, and refuge, where ideas on monetary policy and on techniques of monetary management could be exchanged in the comfortable quiet and most discrete atmosphere of the 'big doughnut in Basle"' (p. 17). As Strange (2015) notes, monetarist thinking meant that BIS took the view "that bankers and other financial actors in the markets are rational enough to moderate their own greed and quell their own fears so that they can be trusted to use the technical information and risk-evaluating methods available to them to discipline themselves" (p. 139).

114 As Teeple (2011) notes: "such policies reflected the rising dominance of money capital, because inflation undermines the value of money, reducing the rate of return on financial assets. Price stability becomes an overriding goal in a financially dominated economy; the constancy of the value of money takes on an importance that it did not previously have" (p. 241). 
market" (Sassen, 2014a, p. 3). Indeed, the Royal's former CEO, Rowland Frazee, often took to the press to publicly complain (in an article aptly titled "Royal Bank Outgrows Canada") that "Canada's greatest current problem is inflation" (as cited in Malcolm, 1980, p. D2). When Trudeau signed Canada onto the BCBS in 1974, he was therefore committing current and future Canadian governments to a policy program guided by neoliberal assumptions that "progress will be brought about via free trade, free capital mobility, and a non-interventionist state" (Soederberg, 2004, p. 76); in other words, "that inflation was the most pressing social problem and 'tight money' the most efficacious solution" (Naylor, 1982, p. 1). ${ }^{115}$

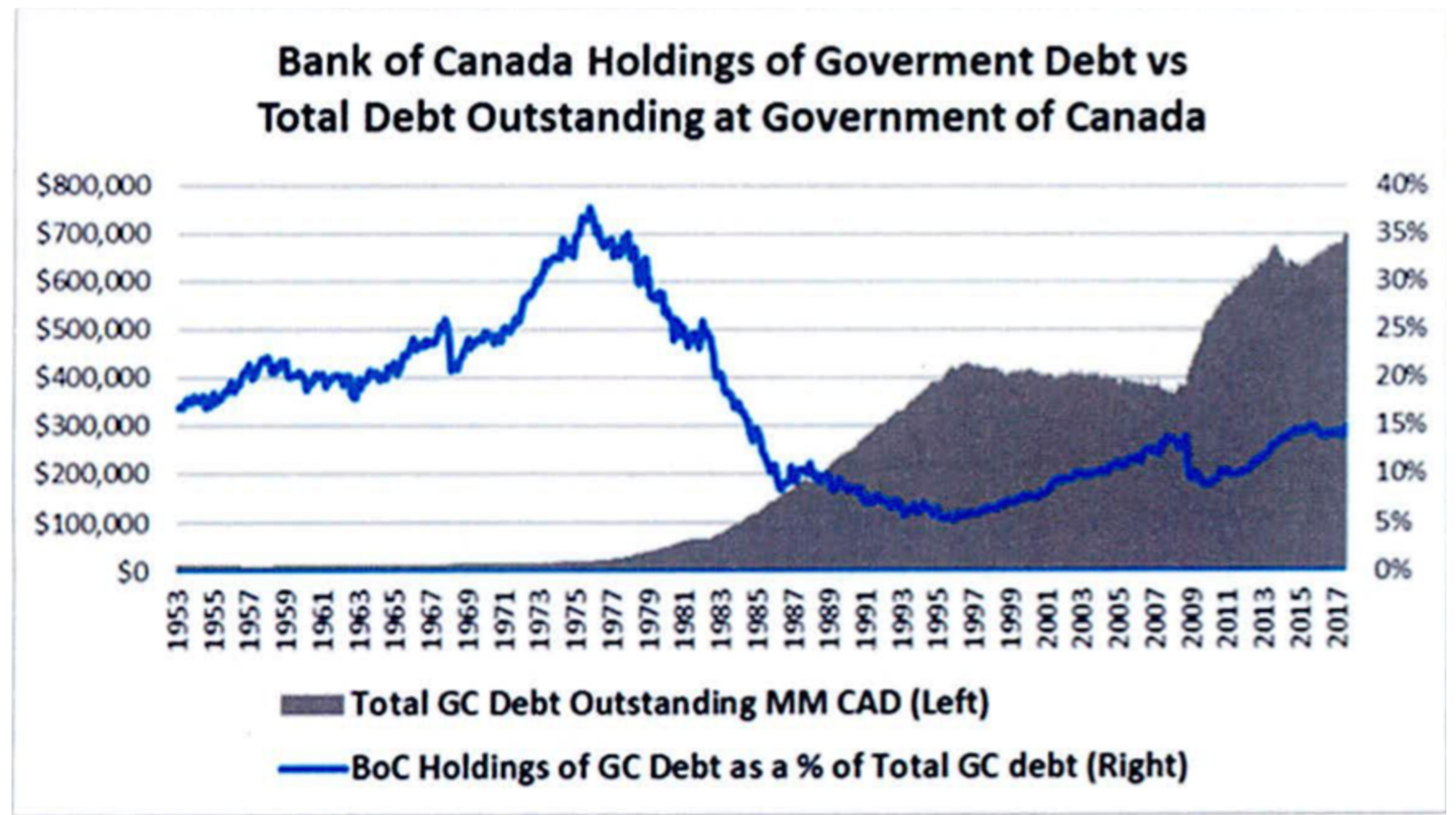

Figure 2. Bank of Canada Holdings of Government Debt vs Total Debt Outstanding at Government of Canada. Reprinted from personal communication with Bank of Canada, October 2017. Copyright 2017 by the Bank of Canada. Reprinted with permission.

115 As Clarkson (2008) notes, the Basel Committee (and thus, the BIS generally) does not possess any formal supervisory authority; it merely creates broad standards and 'best practices' with the expectation that member governments will take the steps to implement them. Countries generally observe the standards "because they participate in making the rules in order to strengthen the hegemony and integrity of the international banking system" (p. 317). 
As Naylor (1982) notes, monetarist policy actually ends up causing a rise in the absolute level of government debt: "for tight money drives up the unemployment rate and slows the grow of national income - causing federal disbursements to rise and tax receipts to fall. And tight money imposes an astronomical increase in the cost of servicing the federal debt" (p. 8). Indeed, the net result of monetarist policy in Canada was an explosion of public debt. From 1867 to 1975 Canada's accumulated debt was only $\$ 21.6$ billion, a period of time that covers two world wars, a long list of infrastructure projects (e.g., the Trans-Canada-Highway and the St. Lawrence Seaway), as well as decades worth of hospitals and universities. ${ }^{116}$ From 1974 to 2013, however, Canada's debt has ballooned to over $\$ 600$ billion, most of which is simply interest on the original loans. By raising interest rates to combat inflation, the Bank of Canada was therefore initiating "a massive redistribution of income towards the rentier class" (Naylor, 1982, p. 17). Indeed, as a result of the monetarist shift, Canada's ability to roll over its debts has increasingly become subject to the confidence of a global cadre of investors "in the management of Canadian financial and economic affairs" (Naylor, 1985, p. 118). ${ }^{117}$ If we recall Henwood's (1998) earlier comment, borrowed from Marx, that "the public debt is a powerful means of ensuring that the state remains in capital's hand" (p. 23), then it should be clear how supranational institutions like the BIS represent the means by which some of those

116 The Bank of Canada was originally mandated to lend not only to the federal government, but to provinces and municipalities as well, with a limit of one-third of a federal budget and one-quarter of a province's. These limits were intended to reduce the risk of hyper-inflation, which they did. See, Qualicum Institute (2014); Statistics Canada (2017).

117 There are numerous examples that capital had a clear role to play in disciplining national governments during this period. Teeple (2000) notes, for instance, that "in both England and New York, financial markets stopped buying long-term debt in order to impose their views that government borrowing and expenditures were too high" (p. 217; see also, Young et al., 2017). The New York example has been explored more recently in the 2016 documentary, Hypernormalisation. 
interests are met; in this case, by increasing the autonomy of the central bank in such a way that its manipulation of interest rates ends up undermining "the policy objectives of the elected government" (Naylor, 1982, p. 33). Furthermore, as Robinson (2014) notes, monetarism has greatly contributed to the overall growth and globalization of banking and finance as "governments from First and Third World alike turn to investors worldwide to finance deficits" (p. 144).

\section{CANADA'S DEBT IN INFLATION-ADJUSTED DOLLARS 1961-2010}

IN BILLIONS OF 2010 DOLLARS

CONSERVATIVE

LIBERAL

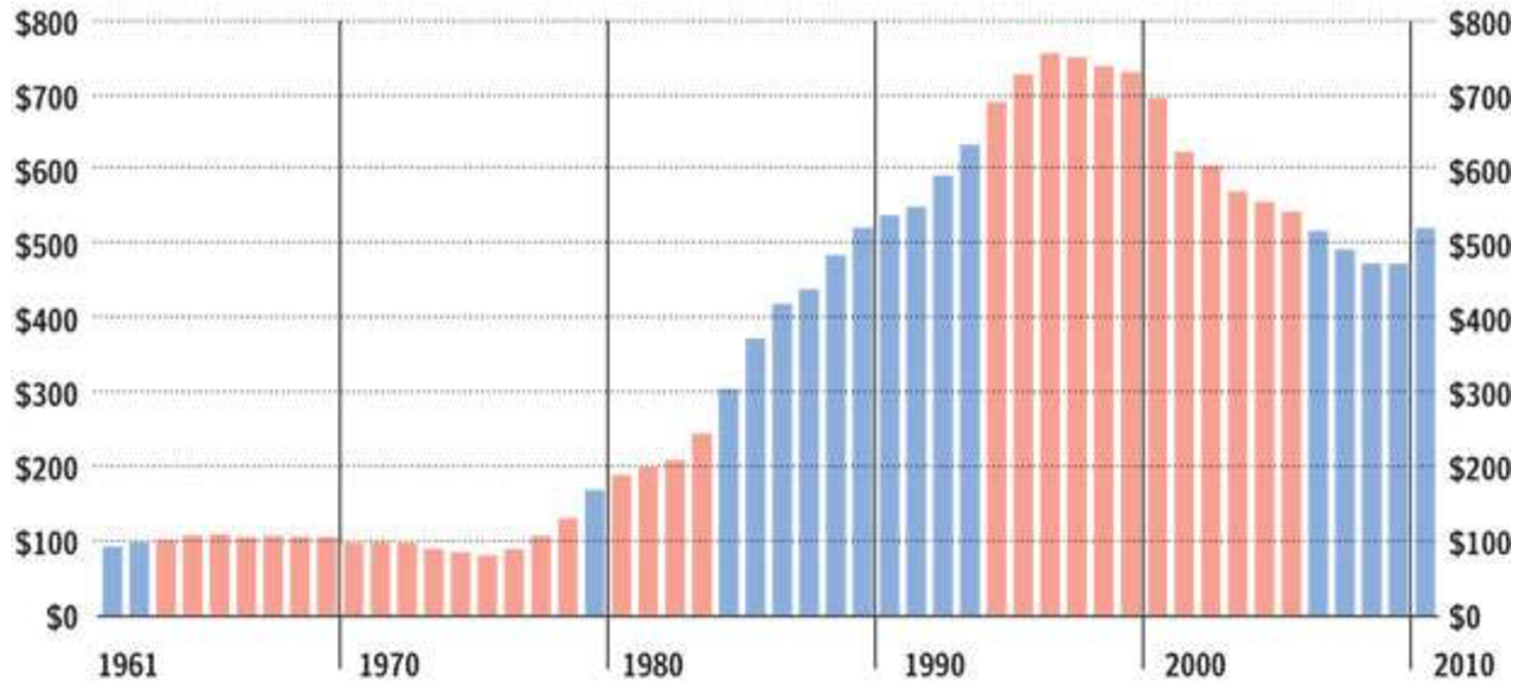

Figure 3. Canada's Debt in Inflation-Adjusted Dollars 1961-2010. Reprinted from the National Post, March 21 2011, retrieved from http:/nationalpost.com/news/canada/canadian-politics/graphic-50-years-ofcanadian-debt/. Copyright 2011 by the National Post. Reprinted with permission.

Hager (2015) has explored this wider phenomenon in the United States, exploring how the holdings of public debt have rapidly become concentrated within the financial sector, subsequently reinforcing "patterns of social inequality," and proceeding "in tandem with a shift in government policy, one that prioritizes the interests of government bondholders over the general citizenry" (p. 505). While the shift in government policy 
toward the satisfaction of bondholders is clearest in respect to the recent Greek financial crisis, it is one felt among all capitalist countries, albeit to different degrees. ${ }^{118}$ The reorientation of the BIS thus represents one aspect of a larger process to shift the raison d'état of the nation-state toward the reduction of inflation and the management of the national currency (Bienefeld, 1992). This process, which expands the state debt, has therefore enabled governments to rationalize cuts to health care, welfare, pensions, education, and so on, all in order to service the immense debt-loads (Teeple, 2000, pp. 103-105). Put simply: "the more government debt, the more states must adopt policies that satisfy the holders of bonds and other creditors" (Robinson, 2014, p. 144). Sassen (2006) notes that it is this shift in particular that is "critical to the particular process of economic globalization that took off in the 1980s" (p. 3).

It is important to recall, however, that the reason for this shift was the immense growth and expansion of financial capital through the Eurodollar markets over the 1960s and 1970s. As Soederberg (2004) notes, the reorientation of the BIS occurred:

as a response to financial capitals to establish a regulatory regime to assist in the continued centralization and concentration of wealth in an interstate system characterized by increasing forms of competition for and dependency on private, short-term financial flows (p. 75).

118 As Teeple (2000) notes: "This indebtedness contains much of the secret of capital's control over the state, as creditor over debtor. Since banks and other financial institutions finance government borrowing, these institutions gain, through the public debt, a powerful lever over state policy. The financial markets can refrain from purchasing government debt, the IMF can and does withhold credit facilities, and bond-rating agencies (such as Standard and Poor in the United States) can set higher interest rates, all by way of reflecting the confidence of capital in government programs and policies. In short, the last thing that the corporations want or can afford is a debt-free state. As present or future tax revenues become insufficient to manage the debt, however, the repayment will be squeezed from reduced expenditures in health, education, and social security, or higher taxes on the working class. The lowering of personal income taxes simply increases the pressure to retrench or privatize the welfare state" (p. 105). 
To put this growth into perspective, by 1974 the Royal Bank of Canada "owned five times more assets than the largest non-bank financial institution, then the Sun Life Assurance Co., and 3.5 times more than the assets of Bell Canada, the largest privately owned industrial corporation" (Van Houten, 1991, p. 95) (see Table 8). In the context of growing public concerns over the increasing size and power of the corporate sector, Canada's federal government created the Royal Commission on Corporate Concentration in 1975 after a rumoured attempt by Power Corp to take over Argus, a large holding company. The Commission (1978) was to report on:

The nature and role of major concentrations of corporate power in Canada; the economic and social implications for the public interest of such concentrations; and whether safeguards exist or may be required to protect the public interest in the presence of such concentrations (p. xix).

The government's official position was that corporate concentration reduces competition and that competition was a necessary means of directing "productive activity in such a way as to maximize national income" (p. 2). ${ }^{119}$ In reality, it is more likely that the government was more concerned with the rate at which capital was flowing out of the country. For the first time in history, Canada was becoming a net exporter of foreign direct investment, most notably to the United States. As Soederberg (2000) notes: "between 1975 and 1984 total Canadian direct investment in the U.S. expanded by 438\%" (para. 10). While many scholars have used this shift as evidence of Canada's status as an imperialist power (e.g., Carroll, 1982, 1986; Kellogg, 2009, 2015; Klassen, 2009; Niosi, 1985)

119 For a critical perspective on the outcome of the Commission, see Gorecki and Stanbury's (1979) edited volume, Perspectives on the Royal Commission on Corporate Concentration. 
it is important to note that this was not by choice, but rather, the result of American TNCs moving their manufacturing plants to cheaper developing countries, forcing Canadian corporations to become "exporters of capital on a far greater scale and [transform] themselves into transnationals" (Van Houten, 1991, p. 153) by virtue of the small size of the Canadian market. Indeed, as Sweeny (1997) notes, the "exceptional nature of the Canadian situation" had always been rooted in the middling range of American-owned industrial firms, which "accounted for $40 \%$ of all industrials" (p. 333). Once they left, however, it forced Canada's largest corporations to seek access to other markets, a process which is fundamentally constrained by the juridical and territorial boundaries imposed by a national system of property relations.

Canadian capitalists responded to the Commission on Corporate Concentration by creating the Business Council on National Issues (BCNI). ${ }^{120}$ The BCNI was essentially a lobby group for globalizing capitals operating in Canada. Led by the chartered banks, along with companies active in resource extraction and manufacturing - what Langille (1987) refers to as the 'staples fraction'-the BCNI was comprised of the CEOs of 150 leading Canadian corporations, which administered over $\$ 700$ billion in assets, $\$ 250$ billion in annual revenue, and employed over 1.5 million Canadians. The list of members originally included the presidents of eight chartered banks, 10 insurance companies, 18 oil and pipeline companies, including Imperial, Shell, Gulf, and Texaco, as well as manufacturers such as Kodak, Ford, and CIL. As Langille (1987) notes, within this lobby group, there was little distinction between American and Canadian corporations, with

120 The group is now referred to as the Business Council of Canada (BCC). 
firms "like Inco, Stelco, and Trizec co-exist[ing] with Xerox, IBM, and ITT" (p. 42). Indeed, by this point the leading firms in both countries, including the Royal Bank, had grown so large as to have "little respect for national boundaries that threaten the flow of capital or hinder their access to new markets" (p. 43). The BCNI was thus the means by which capital could lobby against public concerns over corporation concentration, and the oft-suggested solution of economic nationalism. To do this, the BCNI simply reversed the language of the Commission, suggesting that if the government wanted competition it should simply remove all existing barriers to capital accumulation and allow Canadian corporations to expand abroad unabated.

As one of the most dominant Canadian members of the BCNI, it is not surprising to find the Royal making similar arguments in their own documents. In their Newsletter and Interim Report (1976a), for instance, the bank patronizingly dismisses concerns over corporate concentration as the petty complaints of a spoiled society:

In a society such as ours, where material needs receive high priority, people were prepared to accept some discomforts that have sometimes accompanied increased industrialization. But society's expectations, like the connotation of words, are changing significantly. We reached the stage in Canada where corporate business has, in the course of solving certain problems, been charged with the creation of social problems. And the larger corporate business is perceived to be, then the more vulnerable it becomes to these charges because its actions affect a large number of people and institutions. And it is more visible. This had led to 
increasing demands by the general public for exercise of more direct control of influence over the activities of corporate business (p. 4).

The bank goes on to argue that any attempt to restrict the activities of corporations by way of economic nationalism is to neglect the realities of globalization: "in these days of instant communication across international boundaries, credit can flow from Zurich to Vancouver in the wink of an eye" (Royal Bank of Canada, 1976b, p. 4). The Royal also claimed that any attempt "to build a barricade around the Canadian market" would be "doomed to failure" since Canadian corporations "operate on a world-wide basis, and ... can fund their operations in the financial markets of the world" (p. 4). "The key," the bank claimed, was in controlling "access to the Canadian market so that we can bargain for the best possible access to markets abroad" (p. 4). This was a clear reversal from the bank's position in the 1960s. ${ }^{121}$

The Royal's concern with the best possible access to foreign markets was a response to the decline in American investment in Canada, as well as the size of Canada's notoriously small domestic market. The Royal (1976a) admits as much in an earlier volume of their Newsletter and Interim Report, noting that $30 \%$ of their total profit after tax "is now earned from non-Canadian sources" (p. 4). In fact, the report notes that since the beginning of the 1970s, the bank's net domestic earnings had only increased by an average of $14.6 \%$ annually, compared to their international operations which were growing by an average of $24.3 \%$ annually. In this sense, the Royal's (1976c) size was the only thing

121 "Is it reasonable for Canadian institutions to expect to participate in world markets while we deny foreign institutions access to ours?" (W. Earle McLaughlin as cited in Royal Bank of Canada, 1966, p. 16). 
allowing them "to compete successfully with other world-scale banks" (p. 21), thus forcing them to reject anything that would impact on their size and dominance of the domestic market and their ability to expand abroad. Such claims vindicate Marx's (1867/1991b) comments about capital's inherent tendency toward centralization and concentration as a result of competition; and it is this basic phenomenon that continues to force the transformation of national systems of property relations today.

The Royal's growth concerns were augmented by the continued existence of foreign and near-banks which, in the eyes of the Royal (1976b), had been given unfair advantages despite engaging in banking business. Beginning from the premise that "open competition under equal rules benefits the public" (p. 1), the Royal argued publicly "that all those institutions carrying on banking business no matter how they are chartered and no matter what other business they do, should have their banking activities subject to the federal law" (p. 2). In doing so, the bank would often elicit a subtle nationalist sentiment by reminding the public that "one of the proposals put forward by the Fathers of Confederation when they met for Canada's first Parliament in 1867 was that banking should be a national responsibility" (p. 1). There is obviously a significant amount of irony to these statements given that, as the bank was making them, it was also pushing for further reforms that would remove restrictions on their activities. But the strategy of the chartered banks in this context was fairly clear. As Naylor (1985) notes, they wanted to force "competing financial institutions to come under federal jurisdiction and to hold reserves with the Bank of Canada" (p. 139). By doing so they would significantly hamstring the finances of foreign and near-banks in such a way that the larger chartered banks would be 
able to simply push them out of the market by sheer size alone. The Royal's (1976c) own publications even note that their competitors desire to hedge them in was based on "fears that chartered banks are growing too rapidly" (p. 1).

When the Commission on Corporate Concentration finally wrapped up in 1977, it concluded with the suggestion "that no radical changes in the laws governing corporate activity are necessary at this time to protect the public interest" (Canada, 1978, p. 413). The basis for the conclusion was linked to the growing size of international markets:

If, as seems to be true in many industries, large size is necessary for efficient operations and to compete in international markets, efforts in Canada to reduce corporate concentration by limiting the size of firms will further reduce the competitiveness of Canadian firms in world markets (p. 405).

The Commission was clear, however, that as Canadian firms "expand to world size, there may well be a significant increase in corporate concentration in Canada" (p. 405). In particular, the Commission singled out the chartered banks, which Parliament had already recognized as "major concentrations of corporate power" (p. 219). They were, as the Commission claimed, large by any standard:

Large in Canada, large in terms of their international reputations and operations, large in the number of their branches throughout the country, and large in their physical presence in the buildings with which they are identified in major Canadian cities (p. 221).

The banks were so big in fact that journalist Peter C. Newman (1979) pointed out that "if Canada had as many banks proportionately as the U.S., there would be approximately 
1400 banks in this country, instead of 11" (p. 101). The Commission was also clear to note the significance of the Eurodollar markets to the banks' growth: "foreign-currency operations have made a major contribution to the overall asset and liability growth of the Canadian banks over the last decade" (p. 232). The Commission also warned of the changing nature of international banking, noting that "the biggest and most powerful of the U.S. banks have gone far beyond taking deposits and offering short- and mediumterm loans" (p. 237). ${ }^{122}$ The Commission noted that it would not be "desirable in Canada to have the melding of commercial banking and underwriting functions that is occurring in the United States, because of the very real dangers in concentrating so much financial and economic power in one set of institutions" (p. 237). Since there was "no conclusive evidence that banks are earning monopoly profits" the Commission recommended that the government should "encourage further entry into the industry" so long as new entrants "operate under the Bank Act" (p. 408). This suited the chartered banks just fine of course since their corporate power has always been entrenched and reinforced by the Bank Act. When the revisions were finally revealed in 1980, so-called competition prevailed: all financial institutions were forced to come under federal jurisdiction and hold their reserves with the Bank of Canada. Furthermore, the size of any foreign-owned

122 As explained by the Commission (1978): "If a company wants to expand its financial base, a bank like Citicorp, JP Morgan, Chase Manhattan, or First Chicago will undertake normal short- and mediumterm commercial lending, advise the corporation on possible acquisition or divestiture (at a fee), help it structure and organize a new issue of equity or debt, and also arrange for private placements of these securities with institutional investors" (p. 237). 
banking operation was now limited to $8 \%$ of the domestic assets of all banks. ${ }^{123}$ For the time being, the chartered banks were safe from their foreign rivals.

Not only was the Canadian government now forced by the BIS to rely increasingly on private financial institutions to fund their operations (thus putting any reigning party at the mercy of global investors) but through the BCNI, Canada's chartered banks were sending a clear message that there was little that anyone could do to stop their growth. As discussed in the last chapter, this growth was primarily the result of their unregulated activities in the Eurodollar markets. Where the earlier system of international banking linked countries and banks together along relatively bilateral lines, the Eurodollar markets fostered a much more complex network of transnational and multilateral ties. As Darroch (1992) notes, the Eurodollar markets of the early 1980s had become almost totally transnational, "made possible by instantaneous telecommunications linkages" (p. 164); as such, it not only became increasingly difficult for nation-states to maintain distinctly national capital markets as in the Bretton Woods era, but also changed the relationship between banks and non-financial firms which could now go directly to electronic markets

123 "Under legislation that took effect in Canada today, the size of any foreign-owned banking operation will be limited to $8 \%$ of the domestic assets of all banks. The biggest of the foreign banking operations in this financial center is Citicorp Canada, wholly owned by Citicorp. According to Citicorp Canada's president, Charles Young, his company - by law, not yet a bank - has assets that will reach $\$ 2$ billion (Canadian) by the end of the year. Mr. Young said the Canadian move was part of a trend toward more protectionism, but suggested that Citicorp Canada, with its less than $\$ 2$ billion assets, was hardly a threat to Canadian chartered banks. (Royal Bank of Canada listed assets at April 30 of $\$ 58.5$ billion)" ("Canadian law limits", 1980, p. D1). 
all over the world for loans, a process referred to in the financial literature as 'dis-intermediation.' ${ }^{124}$

Furthermore, the unregulated nature of the Eurodollar markets meant that there were few limits as to what services financial institutions could provide to their clients; as such, this meant that Canada's chartered banks could diversify far beyond the constraints of the Bank Act, which maintained the traditional divisions between the four pillars of Canadian finance: the chartered banks, trust companies, investment dealers, and insurance companies. With Toronto acting as the second capital of the Eurodollar market, Canada's chartered banks were thus easily able to increase their hold on foreign assets. Chodos (1977) notes that by 1976 the banks held $30 \%$ of their assets and $30 \%$ of their liabilities in foreign currencies (p. 106). For the Royal more specifically, international banking activities made up $31 \%$ of its assets and $51 \%$ of its profits by the 1980 s; in contrast, the bank's domestic operations only returned 50 cents on 100 dollars worth of assets, while their international operations returned 84 cents on the same amount (McDowall, 1993, p. 412). The spirit of the age was thus expressed by Royal CEO, Rowland Frazee, when he remarked: "everything we do now we think globally no matter what type of business we're dealing with" (as cited in McDowall, 1993, p. 412).

124 Coleman and Porter (2003) provide an explanation: "In traditional bank lending, deposited funds are intermediated through the bank's corporate structure to borrowers. The cost of bank bureaucracy is offset by the value added by its capacity to monitor the creditworthiness of borrowers, which permits the bank take on the risk of lending. As financial information has become a more widely available commodity, the competitive advantage of bank lending has declined relative to more arm's length securities markets. Securities markets have expanded to include deep markets for short-term (under one year) securities. These markets are often termed money markets. In securities markets, investors themselves take on the risk of lending in mutual funds or by directly financing borrowers by purchasing their bonds or stocks" (p. 246). As Porter (2005) notes, dis-intermediated financial activities surpassed traditional lending activities around the world in 1982. 
The veracity of Frazee's remarks can be seen in the Royal's participation in the Orion Bank consortium, which consisted of Chase Manhattan Bank, National Westminster, Westdeutsche Landesbank, Credito Italiano, and the Mitsubishi Bank of Japan—or "the six most powerful banks in the world" (Hall, 1982, p. 18) as reported in the Financial Times. Formed in 1970 in the City of London, consortiums like Orion were a common feature of the day, and were mainly used to spread risk among many large national banks who were not yet large enough to provide the scale of loans required by expanding corporations and infrastructure projects (Porter, 2005). As the Royal's (1976c) own publications note, Orion played "a vital role in meeting the complex financing needs of governments, corporations and major international development projects" (p. 4). Having financed over $\$ 7$ billion U.S. in loans through Orion by 1976, the Royal would go on to join a number of other consortia in the 1970s related to large infrastructure projects in the North Sea, Mexico, Iran, and Brazil. ${ }^{125}$ But as the banks involved in Orion grew larger as a result of the Eurodollar markets, they began to draw the best business away from the consortium and back toward the parent bank. In response, the Royal bought out their partners in 1980, renaming it the Orion Royal Bank. By incorporating in the City of London, the move allowed the Royal to act less like a traditional bank and more like the sort of integrated financial institutions that would eventually characterize the global financial system of the 1980s.

125 The Royal also became a shareholder in Equator Bank, a consortium catering to the financial needs of post-colonial Africa in 1975 (McDowall, 1993, pp. 410-412). It also joined the Polar Gas project in 1979 to help provide syndicate financing for PetroCanada. 
Orion also allowed the Royal to expand by capturing more business than could be had in the domestic economy alone. As reported in the New York Times, by April 30, 1980: "the Royal's operations outside Canada for the first time produced more after-tax revenues than its operations at home- $\$ 38.1$ million versus $\$ 37$ million on total revenues of $\$ 1.8$ billion" (Malcolm, 1980, p. D1). This trend was not restricted to the Royal alone, however. As Malcolm (1980) notes, the Royal's moves reflected the more general trend of "many major Canadian companies seeking growth beyond the confines of Canada's market of 23.7 million people, smaller even than South Korea" (p. D1). While the Royal's CEO claimed that this outward shift was because "world trade is growing faster than domestic economies" (p. D1), the reality had more to do with the dialectical relationship between the two that was causing unpredictable conditions of profitability. As Robinson (2004) notes: “offshore capital markets grew from $\$ 315$ billion in 1973 to more than $\$ 2$ trillion in 1982 and by the end of the 1970s, trade in currencies was more than 11 times greater than world commodity trade" (p. 112). As such, corporations began to reduce "their risks by diversifying their operations around the world, thus accelerating the entire globalization process" (p. 112). For the Royal, this meant expanding into the more lucrative American market, a reality reflected by their $\$ 100$ million investment in the New York Trust Company in 1979, "a move that rival bankers described as an important new element in the already keen competition for the banking business of medium-sized companies in the United States" (Bennett, 1979, p. D1). The acquisition immediately made the Royal North America's fourth-largest bank in assets, following the Bank of America, Citicorp, and Chase Manhattan. In 1980, Frazee would comment on what all these 
changes meant for the Royal: "We used to be a large Canadian bank with international interests. But now we are a large international bank with a strong Canadian base. There's a difference" (p. D1).

Back in Canada, the recommendations of the Commission on Corporate Concentration were put into place through the 1980 revision to the Bank Act. While the chartered banks were unsuccessful in getting the federal government to impose mandatory reserve requirements on their near-bank rivals, there were, as always, a number of juicy concessions in the form of new rights that reflected their growth and power. The chartered banks were permitted, for instance, "to encroach on the fiduciary activities of the trust companies" (Naylor, 1985, p. 140). They were also allowed to administer their own Registered Home Ownership Savings Plan (RHOSP) and Registered Retirement Savings Plan (RRSP), providing the chartered banks with a cheap source of funds due to "the implicit tax subsidy on the interest rate offered to depositors and because of the exemption from the requirements of holding reserves against them" (p. 140). The chartered banks were also "granted the Orwellian privilege," as Naylor (1985) describes it, "of investing their position funds in their own shares" (p. 140), effectively allowing them to seize part of staff salaries by placing it into the bank's equity base.

The most significant concession, however, was that the new Act required foreign banks to incorporate federally, removing them from provincial jurisdiction (recall that this was an issue for the chartered banks in the last chapter). As a result, foreign banks operating in Canada were restricted from using the assets of their parent bank as the reserves on which they lent. Instead, they were forced to keep their reserves with the Bank 
of Canada, effectively subjecting them to the fiat of the Minister of Finance in respect to their number of branches; their asset-to-capital ratios were also set "at a maximum level well below those of the domestic banks" (Naylor, 1985, p. 140). With their share of total bank assets limited so sharply such that "all foreign banks together, no matter how many there were, could not account for more than about a quarter of the banking activity controlled by the largest single Canadian chartered bank" (p. 141), the foreign banks were essentially restricted from competing against the chartered banks. Put simply, all foreign banks combined could account for no more than a quarter of the Royal's assets. Although some economists saw the 1980 Act as enabling "foreign banks to operate in Canada on the same footing and with the same competitive opportunities as domestic banks" (Boreham, 1989, p. 192), the strict limitations imposed on foreign banks made it clear that it was instead, as Naylor (1985) notes, "a victory for financial centralization and chartered bank hegemony" (p. 140). Furthermore, since there were now more banks in Canada than before, the Act actually allowed the federal government to claim that there was more competition, thus fulfilling the recommendations of the Commission on Corporate Concentration whilst also "deflecting public pressure to curb the monopoly power of the existing chartered banks" (p. 141). More important, perhaps, is that the Act allowed the chartered banks to demand equal treatment abroad. This was significant since, as Darroch (1992) notes, the banks had been facing "declining profitability" at home, forcing them to "expand geographically and in product line to compete" (p. 167). To this effect, the Royal opened an office in Beijing in 1981 to mediate China's access to Eurodollar loans, with 
later offices being opened in Shenzhen, Shanghai, Sydney, Bangkok, Taipei, Seoul, Tokyo, and Singapore for the same purpose.

Some of the Royal's Eurodollar loans would turn sour, however, as a result of the Less Developed Country (LDC) debt crisis. As mentioned above, globalizing banks such as the Royal had been making most of their profits over this period by recycling their Eurodollars (as well as newly generated 'Petrodollars' resulting from the oil shocks of the 1970s) through huge loans to Third World governments (Cameron, 1983). As Robinson (2004) notes: "international bank lending jumped from $\$ 2$ billion in 1972 to $\$ 90$ billion in 1981 before falling to $\$ 50$ billion in 1985" (pp. 111-112). The loans were based on the idea that "countries don't go bankrupt" (Kuczynski, 1988, p. 5). Porter (2005) notes, there are numerous "stories told of young bankers flying around the world eagerly urging developing governments to borrow, on the assumption that governments could never go bankrupt" (p. 53). Supported by the finance ministers of developing countries, the high rates of return on the debt disguised their true nature: it was not long-term bonded debt underwritten by merchant banks, but short-term debt subject to volatile interest rates and economic performance. When Mexico defaulted on its debt payment in 1982 (and with Argentina following shortly after) the international credit system was thrown into crisis. While the Royal had been aware of the coming crisis since the late 1970s, by the 1980s it was already too late. The Bank of Montreal, the Royal, and the Canadian Imperial Bank of Commerce (CIBC) had already "loaned more funds to Latin American states than they had to their respective provincial governments" (Sweeny, 1997, p. 335). To take but one example, in 1979, a group of international banks led by the Chase Merchant Banking 
Group, the Royal Bank of Canada, and the Banco de Reservas de la Republica Dominicana gave a loan of up to $\$ 185$ million to the tiny island nation of the Dominican Republic ("Dominican Republic is lent", 1979, p. D18). In the aftermath of the debt crisis, international losses for the Royal totalled more than $\$ 318$ million by 1983 . With the subsequent devaluation of many Caribbean currencies, the Royal began "an almost total pull out" (Hudson, 2010, p. 44) from the region, prompting the Financial Times to remark in 1986 that "the Canadian banks' 'Caribbean holiday' was over" (McDowall, 1993, p. 406). Other retail banking operations were similarly closed in Germany, France, and Britain.

While the Royal's historian, Duncan McDowall (1993), interprets the LDC crisis as teaching the bank that the new world of global banking was complex, highly volatile, and full of "keen and well honed" (p. 420) competitors, it in fact provided globalizing capital with the means to further discipline developing countries by way of 'structural adjustment' policies mediated through the remaining Bretton Woods institutions. ${ }^{126}$ By the end of 1984, the Royal was already preparing for loan losses of $\$ 2.7$ billion; as such, they "refused to give ground on the issue of absolute forgiveness of the debt" (McDowall, 1993, p. 417). In the case of Brazil, for instance, the Royal's CEO, Allan Taylor, argued that Brazil was "the eighth biggest industrial economy in the world and to think in terms of forgiveness of the debt .... Where would you stop?" (p. 417).

The world's largest banks argued that developing country governments had been irresponsible to borrow so much without making sure "that it was used to generate the

\footnotetext{
126 As Germain (2010) notes: "In the early 1980s, it was the U.S. Treasury-ably assisted by an IMF that was casting about for a new role in a world of floating exchange rates - which took the lead in organizing debt negotiations" (p. 60).
} 
revenue needed to pay back the loans" (Porter, 2005, p. 53). Later, in 1989, the Royal's annual report would claim that as a result of "dealing aggressively with our LDC," that they had "cleared the way for strong earnings growth" (p. 5). 'Dealing aggressively,' was not merely an individual task, however. In reality, all of the world's largest banks, including the Royal, worked together to get the IMF and the BIS to provide short-term loans to debtor nations under the condition that they: (1) increase labour flexibility by caps on minimum wages and other policies to weaken trade unions and worker's bargaining power; (2) increase taxes whilst cutting social spending; (3) privatize public sector enterprises; and (4) remove restrictions on the flow of capital in and out of the country as well as on what foreign corporations and banks could buy (Harvey, 2005). As William H. Rhodes, the Citibank official in charge of Latin American debt negotiations, put it in 1984: "the banks want to be assured that the [debtor] country is going to be pursuing the necessary adjustment program to take it out of its external debt situation to monitor what it is doing" (Wachtel, 1986, p. 125).

The banks claimed that the IMF and BIS were "better equipped" (p. 125) for such a role. ${ }^{127}$ In the case of Guyana, for instance, a group of transnational banks headed by the Royal Bank of Canada helped the country to defer and refinance some \$28.5 million of their maturing Eurocurrency debt as long as they agreed to more loans from the IMF to

127 For more on the LDC crisis and the changed role of the IMF and BIS, see Bederman (1988) and Helleiner (1994, pp. 175-183). 
start paying off their $\$ 400$ million foreign debt. ${ }^{128}$ The transformed role of these supranational institutions was thus one way by which pre-existing protectionist measures and explicitly domestic markets were eliminated in the 1980s via the direct subordination of developing countries to the demands of globalizing capital.

Table 8

Royal Bank of Canada, Annual Statistics, 1974-1985 (\$ thousands)

\begin{tabular}{|l|l|l|l|l|l|}
\hline & Loans & Assets & Deposits & Net Income & $\begin{array}{l}\text { Retained } \\
\text { Earnings }\end{array}$ \\
\hline 1974 & $12,713,031$ & $21,669,880$ & $19,441,373$ & 63,879 & 450,258 \\
1975 & $15,816,493$ & $25,211,131$ & $22,870,875$ & 103,936 & 570,326 \\
1976 & $17,825,430$ & $28,831,586$ & $26,290,831$ & 101,050 & 657,721 \\
1977 & $23,066,315$ & $34,275,159$ & $31,874,374$ & 184,727 & 781,049 \\
1978 & $26,977,407$ & $40,603,054$ & $37,564,356$ & 271,105 & $1,005,686$ \\
1979 & $32,714,333$ & $50,675,587$ & $45,574,896$ & 309,691 & $1,219,329$ \\
1980 & $40,805,248$ & $61,482,111$ & $55,833,184$ & 334,032 & $1,605,621$ \\
1981 & $57,131,133$ & $85,359,452$ & $76,865,388$ & 458,176 & $1,908,263$ \\
1982 & $60,284,459$ & $88,455,992$ & $78,405,462$ & 181,648 & $1,992,544$ \\
1983 & $58,066,890$ & $84,681,823$ & $74,389,208$ & 312,993 & $2,019,893$ \\
1984 & $59,014,248$ & $88,002,708$ & $77,588,345$ & 385,085 & $2,094,484$ \\
1985 & $63,830,803$ & $96,016,863$ & $83,542,969$ & 454,104 & $2,328,842$ \\
\hline
\end{tabular}

Note. Reprinted from Quick to the Frontier: Canada's Royal Bank, by Duncan McDowall, 1993.

\subsection{Big and Little Bangs}

Another shift in TAR that set the stage for our emerging global epoch was the granting of new rights to financial institutions in the 1980s and 1990s that dissolved the

128 The banks included in the group were the Bank of Nova Scotia, Barclays Bank International, Ltd.; Libra Bank, Ltd.; Orion Bank, Ltd.; RoyWest Banking Corp, Ltd.; and two other Royal Bank of Canada subsidiaries, Royal Bank of Canada (International), Ltd., and RBC Finance BV. As part of the restructuring, Guyana also agreed to another \$10 million, seven-year loan agreement with the Royal Bank "designated for general purposes and essential imports" (“Guyana to restructure,” 1980, p. 3). 
historical boundaries between banks, trust companies, insurance firms, and securities dealers. Commonly referred to as deregulation, this process has not only allowed for the creation of immense financial conglomerates, but has greatly contributed to the "onionlike layers of transnational ownership" (Robinson, 2014, p. 34) that continue to blur the lines of corporate nationality. For these reasons, deregulation has considerable overlap among the various literatures on financialization, globalization, and imperialism (e.g., Bienefeld, 1992; Helleiner, 1994; Panitch \& Gindin, 2012; Lapavitsas, 2013; Sassen, 2014a; Strange, 2015; Teeple, 2011; Varoufakis, 2011). Despite very different conclusions as to the nature or constitution of deregulation, there is a shared appreciation amongst scholars that whatever it is that we are referring to in regards to globalization, it is surely wrapped up with the deregulation of banking and finance.

In explaining his theory of global capitalism, for instance, Robinson (2014) writes that with

the deregulation and liberalization of financial markets worldwide in the 1980s and 1990s and the introduction of [computer information technologies], national financial systems have merged into an increasingly integrated global financial system - a monstrous global complex that allows for hitherto unknown concentrations of social power, including the ability to dictate to states and to other circuits of accumulation (p. 135).

Similarly, in expressing his view that Canada is a secondary imperialist power, Klassen (2009) notes that "the circuits of money, productive and commodity capital, have been globalized as governments have deregulated currency markets and liberalized capital and 
current accounts" (p. 164). Vital to this discussion of deregulation is the extent to which it is responsible for allowing money to "move virtually frictionlessly and instantaneously around the world" (Robinson, 2014, p. 136) as it attempts to reach out to investments with the highest rate of return, engaging in "activities of a purely speculative nature" (Teeple, 2000, p. 67). Even the Royal's 1985 annual report notes that "the business environment continued to become more complex in 1985 as the flow of capital around the globe accelerated in its quest for markets offering the best rate of return" ( $\mathrm{p}$. 22). As such, in most accounts of globalization, there is an implicit recognition of the new placelessness of money; in the Oxford Handbook of the Sociology of Finance, the reference is more explicit, with Davis (2012) writing that over the 1980s and 1990s finance "became increasingly unconstrained by state control as the effortless flow of funds through electronic means enabled a new placelessness" (p. 44).

What is neglected when we use words like deregulation to suggest a novel placelessness of money, however, is that both phenomena are the result of new rights for capital, and thus, the transformation of national systems of property relations. If we recall that policies that function to regulate (and thus, deregulate) corporations fall under the theoretical ambit of property relations since they are the rules that regulate what can be done with what is owned (i.e., corporations), then deregulation is simply the removal of a prior restriction on how that property can be used (or, in the case of the corporation, how it uses 'itself' as a rights-bearing entity). As such, it is not so much that money has become placeless, but rather, that it flows more globally by virtue of the right won by finan- 
cial institutions to form together into huge, multi-service corporations, able to operate across multiple territories. Here, Sassen (2012) explains the distinction in terms of TAR:

Territory does not disappear from our global electronic financial system; rather it is repositioned as a network of a hundred plus global cities with major financial centres. And so are authority and rights: neoliberal policy transfers not only power, but also authority to global financial markets and away from national states, and it develops a range of new types of rights for global firms in foreign countries (p. 16).

The point being that under globalization not everything changes. National territorial boundaries remain in existence, and nation-states still continue to protect and defend the property relations that sustain capitalist activity. But the ways in which financial firms are able to operate within this space has been transformed as a result of the new rights they gained in the 1980s. Let us examine these rights.

What we refer to as deregulation can be traced back to what the business press refers to as the 'Big Bang.' The Big Bang was the eventual result of a 1983 agreement between the Thatcher government and the London Stock Exchange to settle an earlier anti-trust lawsuit initiated against the exchange during the previous administration. ${ }^{129}$ When the new rules came into effect on October 27, 1986, they effectively swept away

129 The case was initiated by the Office of Fair Trading against the London Stock Exchange under the Restrictive Trade Practices Act of 1956. These practices included: the London Stock Exchange's rules establishing fixed minimum commissions; the 'single capacity' rule (which enforced a separation between brokers acting as agents for their clients on commission and jobbers who made the market and would theoretically provide liquidity by holding lines of stocks and shares on their books); the requirement that both be independent and not part of any larger group; and, most importantly, the stock exchange's exclusion of all foreigners from stock exchange membership (Centre for Policy Studies, 2006). 
the historical legislation barring banks from owning securities dealers; they also allowed for $100 \%$ outside ownership of member firms within the City of London. As Tony Norfield (2016), a former City trader, notes, the Big Bang not only destroyed the "cosy cartel of British financial firms," but significantly increased the volume of dealing as "international banks flocked to the City of London" (p. 13). Susan Strange (2015) notes, for example, that by the late 1990s, almost nothing remained "of the old, informal, cosy system of self-regulation under the watchful eye of the Old Lady (of Threadneedle Streeti.e., the Bank of England" (p. 153). The type of gentlemanly capitalists who figured prominently in Canada's earlier history "were either long gone or remained only as figureheads" (p. 154), replaced instead by "greedy young Turks with a command of financial technology beyond the comprehension of an older generation - and probably quite beyond the control of the regulators" (p. 154). As journalist Peter C. Newman (1999) outlines in Titans: How the New Canadian Establishment Seized Power, these interrelated transformations of class, technology, and corporate structure were taking place in Canada as well.

The so-called revolution in finance has since led to a number of digitally-mediated financial innovations, such as derivatives (from swaps to futures markets), hedge funds, institutional investment funds, mortgage-backed securities, collateralized debt obligations, Ponzi schemes, and more. ${ }^{130}$ As writers in the global political economy of finance literature note, these innovations made possible a global casino (Strange, 1997) in which "the circuits of financial accumulation steadily take over in the capitalist system,

130 For a good overview of these innovations, see "A glossary of technical terms," in Historical Materialism (2009), 17(2). 
since money capital is universally convertible to any other commodity form of capital" (Robinson, 2014, p. 136). It is important to reiterate, however, that all this has become possible by virtue of the new rights granted to financial firms over this period, enabling the transformation "of any current or future stream of earnings (dividends, interest, mortgages, credit card payments, state and private bond maturities, commodity deliveries, and so forth) into an easily tradable capital asset" (p. 136). This shift has enabled financial institutions to begin speculating through trades taking place at a second (or more) degree of separation from the original origin of the stream of earnings being traded. These new forms of intangible, but still exchangeable, private property have not only had the effect of speeding up the general pace of capital accumulation (often cited by Marxists theorists of imperialism as merely a quantitative change in the mode of production) but also of enabling a massive concentration and centralization of capital to occur as seen in the immense growth of financial corporations over this period.

As Norfield (2012) points out, the decision by London to liberalize their financial market was the result of the United Kingdom "seeing the financial sector as a key area of the global economy in which they had a competitive advantage" (p. 14). This point is backed up by Strange (2015) who writes that the decision was,

in a nutshell, because of competition, of two kinds: transnational competition between the City and Wall Street, and between American and Japanese and British banks; and domestic competition between the insiders who belonged to the cosy clubs and new interlopers who didn't, but were eager to share in the profits ( $\mathrm{p}$. 154). 
There is thus no need to see these developments as it is currently presented in the debate on globalization: as either the result of a TCC that has instrumentalized various economic and political institutions (e.g., Robinson, 2004, 2014); or as a result of the City's satellite status compared to Wall Street (e.g., Gowan, 1999; Panitch \& Gindin, 2012). ${ }^{131}$ Norfield (2016) notes that while major U.S. banks do operate from the City, "the U.K. [also] enjoys significant economic gains from hosting the biggest international banking centre, and its own banks also take an important share of this business" (p. 18). As such, it seems more accurate to view deregulation - like the reorientation of supranational institutionsas the result of the overall growth of national financial capitals to such a degree that their continued expansion ran up against the existing system of property relations. This is especially the case when considering the wider context of capitalist competition in which these changes emerged. The Royal's CEO confirms this view in their 1985 annual report, writing that "in a turbulent world, profit is the ultimate source of financial soundnessthe staying power which provides the foundation for consistently being capable of doing our job in society well" (p. 6). To better understand the extent to which the continued quest for profits led to new rights for globalizing capital, let us once again return to the case of the Royal Bank of Canada.

The Royal took advantage of the U.K.'s Big Bang almost immediately, using Orion to acquire full ownership of Kitcat and Aitken, a London brokerage house. Having al-

131 There are many examples of Robinson's (2004) instrumental view of this process. For instance: “As transnational corporate and political elites emerged on the world scene in the 1980s they made explicit claims to building and managing a global economy through restructured multilateral and national institutions. They pressured for the dismantling of Keynesian welfare and developmentalist states and the lifting of national controls over the free movement of globally mobile capital. They pushed for public sectors and nonmarket community spheres to be opened up to profit making and privatized" (p. 113). 
ready gained access to Australian retail banking earlier that year through a joint venture with the National Mutual Life Assurance Association of Australasia, the Royal would take advantage of similar policies in Australia to form the National Mutual Royal Bank, giving it access to Australian investment banking. Back in Canada, a similar form of deregulation referred to as the 'Little Bang' was stirring as a result of the long-term struggle between Toronto and Montreal to become capital of Canada's financial system.

Having given way to Toronto's Bay Street in the 1970s, Montreal started to pressure Ottawa in the early 1980s to become "a mecca for off-shore banking, a kind of "New York North,' where international bankers could shelter from taxes" (McDowall, 1993, p. 428). Despite the fact that "few had really thought out the actual economic benefit of such a centre" (p. 428), the federal government gave the scheme the go-ahead in February of 1986, adding Vancouver as another of these international banking centres (Martin, 2012). In order to avoid losing tax revenue from the inevitable dislocation of the financial sector from Bay Street along with rumours of British deregulation, Ontario's provincial government jumped the gun and announced in June of 1986 that they were loosening regulations to allow banks, trust companies, and offshore financial companies to acquire up to $30 \%$ of any investment company domiciled in the province. ${ }^{132}$ The chartered banks responded immediately by buying up regional securities firms in Ontario in an attempt to

132 As Martin (2012) notes: “The investment dealers' weakened position, the threat of international competition, and the mounting Quebec-Ontario feud, provided the combination of factors that Kwinter needed. In June 1986, Kwinter announced that Ontario would be the first province to allow banks, trust companies and foreign financial institutions to acquire up to 30 per cent ownership in a broker or investment dealer licensed in Ontario" (p. 9). 
copy Germany's universal banks, with the end-goal of competing with smaller American banks in the American market (Darroch, 1992, p. 167). ${ }^{133}$

With deregulation emerging through the provincial backdoor (a unique feature of the Canadian political economy), the chartered banks set up a conference at Montebello with Michael Wilson, the federal minister of finance, and Stanley Hartt, the deputy minister, in October of 1986 to demand that the federal barrier between commercial banking and investment banking be taken down. As McDowall (1993) notes:

One of the men waiting for Michael Wilson's helicopter at Montebello that fall weekend in 1986 was Allan Taylor, the Royal Bank's new CEO. Throughout the Montebello consultations, Taylor had spoken forcefully on the need for new 'ground rules' in Canadian finance, rules that would preserve public confidence and, at the same time, make Canada's banks globally competitive (p. 429).

The chartered banks argued that without access to the Canadian securities market, they would not be able to compete against banks in London and New York, which had already started to offer securitized loan products. As noted in the Royal's 1985 annual report: "socalled securitization, has spawned a host of new products. Interest rates and currency swaps are typical. These two capital-market products accounted for international financial transactions in excess of $\$ 100$ billion over the past year" (p. 22). The report continues, noting that "the ability to trade and deal in negotiable securities - on an almost instanta-

133 Universal banking refers "to the ability of the bank to be involved not just in taking in deposits and lending for commercial activities but in other financial activities, including short-term money-market securities, derivatives, equities and equity-linked instruments like mutual funds, trusts and estate management, currency trading, insurance, and investment advising and portfolio management" (Coleman \& Porter, 2003, p. 249). 
neous basis worldwide-is now a dominant feature" (p. 22) of the global financial system, and that the blending of commercial and investment banking has become the "major force in the pressure for deregulation in a number of financial markets" (p. 22). In conveying this information to the finance minister they were able to get him to agree "in principle that banks should be able to increase their access to securities either through acquisition of an investment bank, or by creating one, de novo" (Martin, 2012, p. 10). This position was made official in December 1986 when a white paper called "New Directions for the Financial Sector" was released by Thomas Hockin, Minister of State for Finance, which advocated for a similar type of deregulation as in the United Kingdom: The government is proposing that, in principle and subject to the ownership policy described below, there be no restrictions on common ownership of regulated financial institutions. Such institutions will be allowed to hold financial subsidiaries in other pillars (including securities dealers) or to be affiliated with other financial institutions through a holding company structure (p. 6).

In 1987 the Mulroney government thus began a process that would eventually allow Canada's investment dealers to be wholly owned (up to $100 \%$ ) by Canadian banks, trust companies, and insurance companies; a year later, the $50 \%$ ownership ceiling on foreign companies was lifted, allowing foreign firms to own up to $100 \%$ of a Canadian investment bank (Martin, 2012, p. 11).

As a country with one of the highest levels of concentration in the retail financial sector, however, foreign firms never had a chance; the one year head start allowed the chartered banks to quickly swallow up small, regional securities dealers. The decision to 
deregulate thus further tipped the role of the Canadian nation-state toward the directives of globalizing capital by essentially giving " $80 \%$ of the Canadian financial sector to the five chartered banks" (Darroch \& McMillan, 2007, p. 7). For their part, the Royal immediately acquired a $75 \%$ interest stake in Dominion Securities (then, Canada's largest securities dealer) to act as the Canadian anchor for Orion's investment activities. The bank's 1987 annual report described the merging of Canada's largest financial institution with its largest securities dealer as creating "a uniquely Canadian force in the market" (p. 6). While we might dispute the extent to which this force should be considered Canadian, there was no denying that the partnership made the Royal into a force to be reckoned with. By 1989, they were not only three times larger than their nearest non-bank financial rival, Trilon Financial, but also three times larger than the next largest non-financial corporation, Bell Canada (Van Houten, 1991, p. 95).

Deregulation allowed the Royal and the other chartered banks to make a big leap in terms of size by increasing their hold on the domestic market (see Table 9). In its 1992 annual report, the Royal notes that not only were domestic operations becoming more dominant in their overall business mix, "with domestic average assets representing $80 \%$ of total average assets in 1992, compared to $73 \%$ in 1988 ," but that residential mortgages "accounted for almost half of the increase in total assets since 1988" (p. 3). Most of this growth was, as the Royal notes, the result of their newfound ability to enter into financial areas long off-limits to the chartered banks:

The Bank's mutual fund assets have grown from $\$ 1.2$ billion in 1988 to $\$ 4.8$ billion in 1992, now ranking them fourth largest in Canada. In insurance, the 
Bank provides its clients with creditor life insurance and other related products, generating premiums of over $\$ 180$ million annually. The acquisition of Voyageur Travel Insurance Limited, Canada's largest supplier of travel insurance to the retail travel insurance market, announced shortly after year-end 1992, will further enhance the Bank's insurance capabilities. These, and other new non-banking businesses such as investment management, discount brokerage and retirement income services, are expected to be the high-growth areas of the Bank's operations over the next few years (p. 4).

At the time, Bienefeld (1992) remarked on the effect deregulation would have on the banks' activities, stating 'that if Canadian financial institutions are to be 'made' internationally competitive simply by opening domestic markets to competition, then they must perish or become international firms" (p. 53). The reality of Bienefeld's (1992) prediction is reflected in the Royal's own publications. Having referred to itself as a bank as late as 1988, by 1992 it began to call itself a 'financial services institution.' It would only take until 1996 for the adjective global to be added, matching the bank's 1600 branches scattered across 35 countries. 
Table 9

North America's 10 Largest Banks in 1991

\begin{tabular}{|l|l|l|}
\hline Bank & Assets \$ Mil (U.S.) & $\begin{array}{l}\text { Euromoney 100 Best } \\
\text { Ranking }\end{array}$ \\
\hline Citicorp & 216.9 & Not Ranked \\
Chemical Banking & 138.9 & Not Ranked \\
Royal Bank of Canada & 116.9 & 12 \\
BankAmerica & 115.5 & 39 \\
NationsBanks & 110.3 & 81 \\
J.P. Morgan \& Co. & 108.7 & 2 \\
CIBC & 108.1 & 34 \\
Chase Manhattan & 98.2 & Not Ranked \\
Bank of Montreal & 88.1 & 33 \\
Scotiabank & 81.1 & 71 \\
\hline Note. Reprinted from Canadian Banks and Global Competitiveness, by James Darroch, 1994.
\end{tabular}

\subsection{Constructing Bigger Markets}

A further indicator of the centrifugal dynamic that characterizes our present global epoch is the movement of the rights of capital and the authority over those rights to the transnational level; in other words, across the territory of multiple nation-states. It must be noted here that there is not, nor has there ever been, such a thing as a world or global market as is often suggested by theories of imperialism and dependency. There is instead a collection of national markets that are linked together. The reason there is no global market is that markets are constituted by enforceable private property relations within a bounded space. The boundaries of this space are the limits beyond which the institutions of a particular state no longer have jurisdictional authority to enforce the private property relations necessary for the market to function. If the reader recalls our discussion from 
chapter three, the national epoch of capitalism was concerned with the making of a domestic market (i.e., the nation-state) that involved the drawing in of TAR toward the national level. In contrast, our current global epoch has so far been characterized by the proliferation of so-called free trade agreements that establish larger, regional markets, across the territory of multiple nation-states. Emerging in the 1980s, these agreements started to give foreign corporations a number of new domestic rights—chief among them, the ability to sue national or sub-national governments via private tribunals. As Unifor economist, Jordan Brennan (2013), notes, these tribunals are essentially exclusive courts for capitalists that enable global "investors and corporations to constrain government policy and regulation by submitting damage claims for alleged 'interference' with their 'rights"' (p. 24). These investor-state dispute settlement mechanisms are thus especially indicative of the way in which global regimes "only become operative, or performative, when they enter the national domain" (Sassen, 2006, p. 2).

The first of these new, larger markets was the Canada-United States Free Trade Agreement (CUFTA) signed in 1987 and passed into law on January 2nd, 1988, which not only granted Canadian and American corporations new domestic rights in each others' home territory, but phased out a number of restrictions on trade over a 10-year period. The second, was the incorporation of Mexico into the agreement in 1994 via the North America Free Trade Agreement (NAFTA). It is important to note that both agreements utilized existing national legal systems to remove barriers to trade in goods and services by creating a legal framework for investor-state disputes. It is in this sense that the nation-state can be said to have jumped tracks by becoming a capability to support the 
interests of globalizing capitals. As Mertins-Kirkwood (2014) notes, both agreements, "represented an important shift from mere market access to an all-encompassing market presence for foreign capital" (p. 20). Far from the earlier international trading system initiated by Bretton Woods and the General Agreement on Tariffs and Trade (GATT) that involved the strengthening of the powers of the nation-state to regulate capital, NAFTA and other similar agreements not only extend far beyond trade in goods, including investments, services, non-tariff barriers, and the protection of intellectual property rights, but also involve the de facto re-writing of national constitutions such that the nationstates ability to legislate against capital is reduced: "simply put, they serve to protect almost all forms of economic activity and capital investments from 'excessive' state intervention" (McBride, 2005, p. 88). As political scientist Stephen McBride (2005) notes, this not only means that private actors (TNCs) have acquired rights that have strengthened their hand against public ones (states), but that "many capacities used in the national policies under which Canada developed are now beyond the reach of governments" ( $p$. 186). As such, the efficacy of national political rights is reduced as the nation-state is forced to defend the rights of globalizing capital, reducing the potential for a diversity of policy options to be presented to the voting public.

While many Canadian political economists still view these trade agreements as expressions of American domination (e.g., Hurtig, 2003; Ikeda, 2004; Jackson, 2007; McQuaig, 2007; Seccareccia, 2007) it is important to point out that, from the start, these agreements were promoted by globalizing Canadian firms who were not able to support their scale of enterprise by the domestic market alone. McBride (2005) notes, for exam- 
ple, that a delegation from the BCNI "broached the free-trade idea with American officials as early as 1982 and began to publicly promote the idea in Canada from 1983” (p. 58). After Brian Mulroney's Conservative Party was elected in a landslide win in 1984 , the BCNI doubled their efforts. The Royal Commission on Economic Union and Development Prospects had been appointed by Pierre Trudeau in 1982 and presented its recommendations to Mulroney in 1984 . Headed by former Liberal politician Donald Macdonald, during the Commission both the BCNI and the Canadian Manufacturers Association (CMA) argued "that they could compete with the United States if given the chance" (p. 62). Despite referring to the proposed trade agreement as a "leap of faith," Macdonald concluded that "if these people say they can compete in a free market, who am I to say they cannot?” (p. 62). In his history of corporate Canada, Van Houten (1991) agrees, noting that CUFTA "was advanced as the solution to Canadian monopoly's predicament and hence it was prepared to make whatever compromises and sacrifices necessary to protect its interest in the U.S.” (p. 154). With the support of the Commission, CUFTA was signed in 1987 and passed by the House of Commons in 1988. The Royal's 1989 annual report would commend the move, noting that "a strong North American base is fundamental to our vision of becoming a major North American 'corporate' bank and leading Canadian bank in the United States," and that "the prospects for developing new, quality business in the United States have been enhanced by the Canada-U.S. Free Trade Agreement" (p. 5).

Shortly afterwards, in 1992, the Bank Act was again up for revision. Continuing the process of removing the legal barriers that divided Canadian finance, the 1992 revi- 
sions gave the chartered banks the "power to diversify into new lines of business through financial institution subsidiaries, as well as through increased in-house powers" (Daniel, 2002, pp. 4-5). The revisions gave the banks and the insurance companies the right to own trust companies; bank, trust, and loan companies the right to own insurance companies; and widely-held non-bank financial institutions the right to own Schedule II banks, or closely-held banks. For the Royal, this meant buying up one of Canada's oldest trust companies, Royal Trust. Long associated with the Bank of Montreal, the acquisition not only provided the Royal with a "huge block of assets," but immediately transformed them into "the fourth-largest financial institution in North America" (McDowall, 1993, p. 431). The Act also abolished reserve requirements on the chartered banks, leaving them to determine whatever amounts of reserves they wanted to hold. Although they were still required to "maintain non-negative settlement balances with the [Bank of Canada] on a daily basis" (Handa, 2002, p. 262) they were no longer required to keep any deposits with the Bank of Canada, with the BIS instead setting capital requirements on global banks and financial institutions since $1988 .^{134}$ As such, the 1992 Act simply continued the process by which previously divided Canadian financial institutions - namely, the chartered banks, but also the large insurance companies - were transformed into huge, multiservice conglomerates. The revision schedule was also shortened to five years to better match the quickening pace of change.

\footnotetext{
134 As early as 1983, Cameron had noted that "in the evolving global order, the importance of official reserves acquired in the market has declined, and the significance of international credit provided by transnational financial capital has increased" (p. 105).
} 
Given their acquisition of Royal Trust, the Royal Bank of Canada was relatively well-positioned by the time NAFTA was signed in 1994. More forward looking than the bilateral CUFTA, NAFTA was crafted in such a way as to be extended to other countries over time; it has since provided the basic model for other multilateral trade agreements, such as the Canada-European Union Trade Agreement (CETA), and the currently stalled Trans-Pacific Partnership (TPP). As White (1994) notes, the American governmentwhich was at the time representative of the world's largest and most powerful financial firms-hoped that the provisions relating to the exchange of financial services "might establish a global model" (p. 12) that could be used in negotiations relating to the General Agreement in Trade and Services (GATS) treaty. The goal of the United States was to use NAFTA and the GATS as a means of forcing nation-states to open up their financial systems by giving foreign firms new domestic rights which would ensure equal access to markets subject to non-discriminatory regulation. Indeed, as Gould (2010) notes, one aspect of the more recent Doha Round of negotiations to expand the World Trade Organization (WTO) involved "getting countries to further liberalize their financial sectors" by granting foreign interests the right to acquire existing companies as well as to establish new ones. National governments would then be responsible for guaranteeing the rights by making binding commitments under the GATS, with these rights "enforceable through the WTO dispute system" (p. 1).

Far from being evidence of a regional imperialist strategy on behalf of the United States, it is important to recall that such agreements provide rights to foreign corporations located in member jurisdictions; as such, the firms involved may not even be 'Canadian' 
or 'American' by most measures of corporate nationality. As Robinson (2012) notes, these regional markets do not "carve out separate regions" of capitalist activity but rather, act as "regional transnational platforms for furthering capitalist globalization" (p. 411). They do this primarily through the attached investor-state dispute settlement (ISDS) mechanisms, which compel countries who break the terms of the agreement to change their policies according to the ruling of a private tribunal. Free trade agreements are thus less about trade and more about granting foreign corporations new domestic rights that work to constrain the legislative options available to the host nation.

Under NAFTA's Chapter 14, for instance, the governments of Canada, the United States, and Mexico all agree to refrain from discriminatory behaviour against financial institutions based in each others countries, regardless of whether those companies "are investing in actual foreign premises or providing cross-border services from their home countries" (Clarkson, 2008, p. 315). NAFTA also requests that member countries that run into into macroeconomic trouble "remedy the situation by seeking and taking the advice of the International Monetary Fund and such other relevant bodies as the World Bank" ( $p$. 316). This ultimately means the same sort of austerity policies previously pushed on developing nations, along with the further privatization of public resources. Member countries are also restricted from excluding services from the market (e.g., education, healthcare, and so on) via the creation of new social rights; in other words, national governments have only the option of further privatization. This is why there is little chance of going back to any form of welfare state under the terms of these agreements; they essen- 
tially restrict the range of policy options available to governments. In other words, they restrict what governments are entitled to govern.

Today's free trade agreements are thus less about imperialism and more about giving capital new rights that limit the nation-state from restricting its expansion. As Clarkson (2008) notes, NAFTA has not only reduced "the authority of constitutionally established national authorities," but has done so in a way that increases the "autonomy and capacity for TNCs liberated from national control” (p. 470). Few Canadians know, for example, that Canada's federal government has already paid out NAFTA damages totalling over $\$ 172$ million to a variety of TNCs (Sinclair, 2015). The United Nations (2013) also notes that these settlements are on the rise, with the total number increasing to 514 around the world by the end of 2012. As such, what we are referring to in the context of globalization is not merely a competition of national capitals backed by their respective nation-states, but rather, a more complicated process through which the nationstate is being made into a capability for globalizing capitals via already existing national legal frameworks. As Sassen (2006) explains:

In this process, particular legal protections get detached from their national territorial jurisdictions and become incorporated into a variety of often highly specialized or partial global regimes and thereby often become transformed into far more specialized rights and obligations. I also see in this dynamic capabilities jumping tracks and becoming lodged into a novel organizing logic. One example is the bundle of rights granted by host states to foreign firms under the WTO which unsettles older national regimes. Many of these rights and guarantees 
derive from what were once national rights and guarantees used precisely to distinguish national firms from foreign firms; these rights and guarantees were also one critical component in the building up of the state's exclusive authority over its national territory [emphasis added] (p. 417).

In the third chapter, we explored the creation of the national market which consisted constructing a national system of rights for the ownership of private property. Under this earlier system, foreign corporations were typically subject to the laws (and perhaps, arbitrary decisions) of the host government under which business took place. Under free trade, however, the rights of capital are spread across multiple jurisdictions, forcing member nation-states to protect the interests of all 'local' corporations. The purpose of free trade is thus to protect corporations from national legislation that could potentially impact the continued accumulation of capital. As a result, these agreements reinforce the concentration and centralization of capital since corporations must grow larger and larger to survive against their similarly globalizing rivals.

In the case of the Royal Bank of Canada, for instance, NAFTA not only gave them new rights in the American market, which had been the principal source of revenue for all of the chartered banks over the course of the 1990s, but also an immediate impetus to get much larger. The need to get larger was the result of a worldwide mergers and acquisition (M\&A) boom in the mid-1990s. As the Royal notes in their 1996 annual report: "consolidation is a worldwide industry trend. In Japan, the merger of the Bank of Tokyo and Mitsubishi Bank has created the world's largest bank with more than $\$ 700$ billion U.S. in assets" (p. 15). The report thus made the recommendation that Canadian banks "consider 
the merits of mergers" (p. 15). With NAFTA already putting pressure on the Canadian government to allow cross-border branching, the chartered banks were all too aware that they might soon have to compete at home with larger, more powerful, American banks. This reality was confirmed in late 1997 when the Canadian subsidiaries of Citibank and American Express both won large Canadian government contracts over the Bank of Montreal. The late 1990s also saw ING, MBNA, Fidelity Investment, Merrill Lynch, and Wells Fargo all enter the Canadian market in one form or another.

The chartered banks responded to the arrival of American firms into Canada by announcing merger plans. Despite the fact that the Royal's earlier acquisition of Royal Trust had made it the fourth-largest financial institution in North America, the CEOs of both the Royal and the Bank of Montreal announced their plans to merge into a single 'super bank' on January 23rd, 1998. Within weeks, the CEOs of rival banks TD and CIBC proposed a second merger; the Bank of Nova Scotia (Scotiabank) was left without a merger partner. The proposals brought forth a renewed chorus of alarm from consumer groups, small business advocates, and politicians who noted that, if approved, the two new super banks would control over $70 \%$ of Canada's banking assets. While the government considered the mergers, Scotiabank chairman, Peter Godsoe, took the time to dismiss the other banks' arguments as fear-mongering: "I do not believe Canadian banks face a crisis or that foreign competition is about to overrun us" (Whittington, 1999, p. 24). Godsoe was, in fact, correct: by 1998 foreign banks made up only $10 \%$ of total assets of Canada's banking sector. Of this $10 \%, 7.3 \%$ was business credit and $2.8 \%$ was credit to small and medium-sized business (Whittington, 1999, pp. 96-97). As Clarkson (2008) 
notes, foreign financial subsidiaries had actually been losing market share in Canada for some time (p. 307).

There was an argument to be made about the size of American financial firms, however. Mergers in 1997 and 1998 had led to the creation of a small group of American super banks:

Five giant financial-services merger proposals in the early months of 1998 doubled the value of all 1997 transactions. These were deals to join NationsBank and Bank America (\$60 billion U.S.), Banc One and First Chicago (\$30 billion U.S.), Norwest and Wells Fargo (\$34 billion U.S.), Sun Trust Banks and Crestar (\$10 billion U.S.), and Citicorp and Travelers Group (\$70 billion U.S.) (Whittington, 1999, p. 69).

Similar to the merger wave at the turn of the twentieth century, this wave "defied all expectations and catapulted ahead with a fury that left investors, analysts, and average citizens in awe, and sometimes in fear" (p. 70). While worldwide M\&As totalled only \$1.6 trillion (U.S.) by 1997, by mid-1998 merger values had already reached $\$ 1.3$ trillion, "double the total for the same period of 1997 and almost equal to the value of all deals recorded in 1997" (p. 71). As Whittington (1999) notes, this activity was so intense that on May 18, 1998, 11 mergers worth roughly \$17 billion took place.

There were a number of factors behind the 90s M\&A wave. The most significant was the belief that "bigger is better in the global marketplace" (Whittington, 1999, p. 70). As national markets were increasingly opened up to global competition, capitalist logic dictates that only the largest firms should survive. As Strange (2015) notes: "it is the larg- 
er enterprises that are less at risk from their competitors" (p. 182). As such, globalization substantially accelerated the pace of economic concentration in big business, a process which has had the subsequent effect of diluting "the national identity of business enterprise" (p. 182). Even the chartered banks admitted that they wanted to merge so that they could "cut expenses, share the high costs of future capital investment and boost their capital for expansion outside the Canadian market" (Bowley, 1999, p. 16). The reality of these pressures is reflected in the Royal's acquisition of Credit Suisse's Private Banking North America in 1998, just prior to the federal government's decision on domestic mergers. The move was part of a larger strategy by the bank to strengthen its "U.S. wealth management capabilities" (Morrison, 1998a, p. 16) in the context of the merger decision. The Royal also formed a strategic alliance with Koch Industries, the second largest privately held company in the U.S. and a leading commodities derivatives trader, "to market their energy-related trading and derivatives products" (Morrison, 1998b, p. $40)$.

Despite these moves, the Royal, along with the other chartered banks argued that America's super banks still had a cost advantage that would allow them to deliver financial services more efficiently through new technology. Basing his recommendation on a report from Big Four accounting firm Ernst and Young, and with internet banking still in its early stages, Minister of Finance Paul Martin (1998) responded to the chartered banks, stating that electronic banking was "a poor substitute for many of the services provided by a branch" (para. 68). Since the Competition Bureau's mandate only covered a twoyear window, they ended up rejecting the mergers on the basis that the Internet would not 
replace the need for a physical bank presence in the next five to 15 years. In the wake of the rejection, Dominic D'Alessandro, president of Manulife Financial, predicted that "the thrust of the banking system into related activities such as insurance is going to be more pronounced as a result of their frustration at not being allowed to merge" (Whittington, 1999, pp. 246-247). Similar remarks were made by banking analysts who noted that “mergers are going to happen. The only question is when" (Warn, 2000, p. 33).

Having been denied the right to merge, and in spite of robust profits, the Royal immediately cut " 6,000 full-time jobs, or more than $10 \%$ of the workforce" (Bowley, 1999, p. 16) and began to look outside Canada for further acquisition opportunities. ${ }^{135}$ As their primary foreign market, this meant moving deeper into the United States (Coleman \& Porter, 2003). As Clarkson (2008) notes, the American market was especially attractive due to their own version of deregulation, which enabled the chartered banks to acquire a number of "niche service providers and large subregional banks" (p. 308). For their part, the Royal spent up to $\$ 5.3$ billion in 2000 on such purchases, including the $\$ 650$ million purchase of Liberty Life Insurance, the $\$ 1.4$ billion all-cash acquisition of U.S. brokerage and investment management firm, Dain Rauscher Wessels, as well as "the \$2.2 billion purchase of Centura Banks of North Carolina" (p. 308).

The Royal also combined their lobbying efforts with other foreign banks through North America's banking associations. As Clarkson (2008) notes, these associations now represent banks from all over the world, with lobbying efforts "based on individual is-

135 An article in the Financial Times noted that as a result of the merger decision, the Royal planned to cut \$267 million "in expenses over the next two years and reduce its corporate lending and investment banking activities outside Canada, while bolstering its wealth management and electronic commerce divisions" (Alden, 1999a, p. 26). 
sues, not on the geographical positions of their headquarters" (p. 320). In the Canadian Banking Association (CBA), for instance, "foreign banks from a wide variety of countries constitute the Foreign Bank Executive Committee, in which British HSBC, Canada's largest foreign bank subsidiary, is the most influential member" (p. 321). The result of these efforts was a 2001 decision to further liberalize the Canadian banking industry by moving the widely-held ownership cap from 10 to $20 \%$ of voting shares and $30 \%$ for non-voting shares. ${ }^{136}$ While the move was welcomed by foreign governments and investors, ${ }^{137}$ the driving force for the change was from the chartered banks themselves, who wanted to raise more capital to boost their global competitiveness.

The Royal's obsession with becoming globally competitive came not simply from geographic pressures, but also from sectoral pressures relating to the new rights gained by financial institutions in the 1980s. While these new rights enabled the chartered banks to transform into huge financial service conglomerates, they fundamentally "changed the structure of the financial sector and greatly extended the range of its products" (Dow \& Dow, 2014, p. 115). As Lapavistas (2014) notes, what we commonly refer to as financialization more accurately refers to the way in which these new rights shifted the financial

136 The federal government also reorganized Canada's financial markets, making the Toronto Stock Exchange for senior securities, the Montreal Exchange for exchange-traded derivative products, and the merged Alberta Stock Exchange and Vancouver Stock Exchange taking responsibility for all junior securities (Coleman \& Porter, 2003, pp. 252-255).

137 Canada is currently the only country in the Organization for Economic Co-operation and Development (OECD) that does not allow cross-border branching. So far, Canada has been able to hold on to the widely-held rule by virtue of its non-discriminatory wording in respect to nationality: "no one person (Canadian or foreign) may own more than 10 per cent" (Gould, 2010, p. 4). It is unclear, however, how long this will last given the extent to which other countries have criticized the rule as an indirect form of protectionism. 
sector toward open profit-making on the financial markets. ${ }^{138}$ With the growth of electronic markets in the 1980s, large non-financial corporations began to retain their own funds to engage in financial trading, thereby reducing their dependency on banks for loans, a process referred to in the literature as dis-intermediation. In response, the world's largest banks shifted from outright borrowing and lending to "transacting in open financial markets with the aim of making profits through financial trading" (Lapavistas, 2013, p. 794).

The result was an immense rise in the amount of financial speculation. In 2000, for instance, worldwide trade in goods and services was less than $\$ 10$ trillion for the entire year, whereas "daily movements in currency speculation stood at $\$ 3.5$ trillion, so that in just a few days more currency circulated as speculation than the international circulation of goods and services in an entire year" (Robinson, 2014, p. 145). As Robinson (2014) notes, this blurs the "boundaries between industrial, commercial, and money capital" (p. 22) by drawing non-financial corporations into the financial sector. In Canada, these changes are reflected in the shift toward corporate financing by pension funds belonging to groups like the Ontario Municipal Workers (OMERS) and the Ontario Teachers' Federation (OTF), as well as the move by retailers such as Loblaws, Walmart, and Canadian Tire to provide their own financial services (Darroch \& McMillan, 2007). Becoming globally competitive for the Royal in this context was thus no mere matter of being able to compete against rival banks, but to do so in an environment where the dominant form of wealth was made by trading on electronic markets by any firm who had the

138 For an in-depth look at the qualitative nature of this shift, see Coleman and Porter (2003), Henwood (1998), Marazzi (2010), Porter (2005), and Strange (2015). 
financial means to do so. In a nod to the increasing role of computer technology, the Royal once again changed their name, this time simply to 'RBC.'

RBCs efforts at growth were momentarily stalled in 2007 , however, with the beginnings of what would later become a global financial crisis. The crisis was, without question, the result of the new rights granted to banks and other financial institutions in the 1980s. As Dow and Dow (2014) note, it was "the power exercised by the banks over governments" that eventually forced deregulation, enabling the creation of huge financial services conglomerates that dominated the global economy. In the 20 -year period leading up to the crisis, the financial sector had become the world's largest industry—bigger than oil, autos, and consumer electronics combined. By 2007, the world's largest financial institutions had a "market capitalization well in excess of $\$ 200$ billion, more than $25 \%$ of Canada's annual GNP” (Darroch \& McMillan, 2007, p. 5). As such, the new rights gained by the banks, as well as the increasing use of information technology enabled them to engage in a particular type of commoditization of finance, in which loans were immediately treated as assets to be sold on global financial markets "with no intention of establishing a relationship with the borrower" (Harris, 2010, p. 70). This type of commoditization gave rise to further innovations that facilitated the transformation of high-yielding and highly risky assets (e.g., mortgage loans and credit card receivables) into complex aboveaverage yielding financial products. Sold mainly to institutional investors such as pension funds, these financial products were hard to decipher, leaving regulators, risk committees, rating agencies, and more importantly, investors, scratching their heads as to how they worked. Furthermore, banks increasingly made their loans on the basis of "credit-scoring 
rather than the exercise of judgement and used quantitative models to represent their risk profile (as required by the Basel capital adequacy rules)" (Dow \& Dow, 2014, pp. 115116). In the end, it became apparent that the world's banks had essentially created much of the value of these assets themselves. In Canada, for instance, the total size of the market "was about $\$ 116$ billion before the global financial collapse and the chartered banks had originated some $75 \%$ of the total" (Harris, 2010, p. 71). Put simply, Canada's chartered banks, like the rest of the world's banks, had figured out how to make money from nothing.

One of the more significant consequences of the crisis, however, has been the use of public state funds to bail out banks and other financial institutions when the house of cards comes crashing down. Despite the common refrain that Canada has one of "the most sound banking systems in the world" (Macdonald, 2012, p. 5) or that the government "has not had to put any taxpayers' money into our financial system" (p. 8), in actual fact, the federal government started making provisions to buy insured mortgage pools from the chartered banks as early as 2008 . Referred to as 'liquidity support' instead of a bailout, the amounts transferred were immense, with both Canadian and non-Canadian banks taking advantage of the program (Whiteside, 2012). As revealed by economist David Macdonald (2012) in a study entitled “The Big Banks’ Big Secret," Canada's chartered banks received bailouts from Canada's federal government that went up to $\$ 114$ billion in March 2009 during the peak support period: "to put that into perspective, that would have made up 7\% of the Canadian economy in 2009 and was worth $\$ 3,400$ for every man, woman and child in Canada" (p. 6). For RBC specifically, which "received 
the third highest level of support for Canadian banks after TD Bank and Scotiabank" (p. 22), the bank hit its first peak borrowing in March 2009 at approximately $\$ 25$ billion; a second peak appeared in July of 2009 , hitting just under $\$ 23$ billion. It is thus rather shocking, considering the official view at the time was that Canada's banks did not receive nor require a bailout, that $\mathrm{RBC}$ was able to receive support worth " $63 \%$ of its market cap in February 2009”' (p. 22).

As political sociologist Bob Jessop (2015) notes, bailouts reflect the growing power and size of financial capital within the global economy:

If financial capital is well-entrenched in the state apparatus, then the capacity to rescue 'too big to fail' financial institutions also exists when states can create fiat money and engage in other credit manoeuvres to socialize toxic assets and losses (para. 99).

Macdonald (2012) admits that his own figures are mere estimates because much of the information on the size of the bailouts has not been released publicly, despite the fact that they utilized public monies. As he notes, this veil of secrecy obscures an obvious reality: that "Canada's big banks are too big to fail. The Government of Canada, the Bank of Canada, and the big banks themselves understand that Canada's banks will be bailed out irrespective of the cost" (p. 30). What is important to understand, however, is that these bailouts were not simply a bailout of Canada's chartered banks, but rather, of all of the banks who have the right to access the Canadian market. Despite former finance minister Jim Flaherty's 2009 comments that the reason for the bailout was "so that our banks would not be at a competitive disadvantage internationally because of the intervention of 
other governments with respect to their banking systems" (Mason, 2013, para. 4), the bailout was offered to, and taken by, both domestic and foreign banks. As such, nationstate institutions today are becoming less a capability for explicitly national capital, as they are in theories of imperialism and dependency, and more a capability for the world's most dominant globalizing capitals.

Furthermore, as a result of the crisis, new supranational regulations for too big to fail banks have been unveiled by the newly created Financial Stability Board (FSB) which is managed by a small administrative office at the BIS in Switzerland. ${ }^{139}$ The FSB now requires 'global systemically important banks' to hold at least 15 to $20 \%$ of their assets ("Too big too fail," 2014). Although none of Canada's chartered banks were placed on the list, they are still subject to new reserve requirements as 'domestic systemically important banks' (“Canadian banks don't,” 2012). Far from the earlier system of national authority over financial actors, the FSB is simply the newest organization to join the patch-work system of supranational institutions that work to prop up the global financial system. There is thus good reason to question claims that, as a result of the crisis, "the historical sweep of financial governance is about to experience a renewed assertion of the nation-state as the central locus of regulatory authority" (Germain, 2010, p. 12). While nation-states will certainly have to deal with the outcomes of financial crises, in reality, much of the work of financial regulation in the post-crisis period has been under the di-

139 The FSB was actually formed out of the earlier Financial Stability Forum (FSF), which was created under the leadership of the G7 countries after the Asian and Russian financial crises of 1997. Their stated goal was to improve transparency and supervision, and thus, stability, of the global financial system. As Clarkson (2008) notes, the FSF coordinated a number of institutional actors, "including the G7 finance ministers, central bank presidents, national supervisors, the BIS, the World Bank, the IMF, and the OECD” (p. 317). 
rection of supranational institutions (e.g., Helleiner, 2013), signalling the continuation of our period's centrifugal dynamic.

Table 10

Canada's Biggest Companies By 2007 Revenue

\begin{tabular}{|l|l|l|l|l|}
\hline Company & \multicolumn{2}{|l|}{ Revenue } & \multicolumn{2}{l|}{ Profit } \\
\hline & $\begin{array}{l}\text { Amt. 2007 } \\
\text { (x1000) }\end{array}$ & Change & $\begin{array}{l}\text { Amt 2007 } \\
(\mathbf{x 1 0 0 0})\end{array}$ & Change \\
\hline 1. Royal Bank of Canada & $\$ 41,307,000$ & $14.6 \%$ & $\$ 5,492,000$ & $16.2 \%$ \\
2. Manulife Financial Corp. & $\$ 35,533,000$ & $3.9 \%$ & $\$ 4,229,000$ & $6.5 \%$ \\
3. George Weston Ltd. & $\$ 32,815,000$ & $2.0 \%$ & $\$ 563,000$ & $365.3 \%$ \\
4. General Motors of Canada Ltd. & $\$ 31,675,000$ & $-5.0 \%$ & $\mathrm{~N} / \mathrm{A}$ & $\mathrm{N} / \mathrm{A}$ \\
5. Power Corp. of Canada & $\$ 29,408,000$ & $-3.0 \%$ & $\$ 1,463,000$ & $5.0 \%$ \\
6. Magna International Inc. & $\$ 27,995,958$ & $2.1 \%$ & $\$ 712,062$ & $18.9 \%$ \\
7. Alcan Inc. & $\$ 26,808,894$ & $8.9 \%$ & $\$ 2,029,860$ & $1199.4 \%$ \\
8. The Bank of Nova Scotia & $\$ 26,467,000$ & $17.5 \%$ & $\$ 4,045,000$ & $13.0 \%$ \\
9. The Toronto-Dominion Bank & $\$ 25,209,000$ & $13.0 \%$ & $\$ 3,997,000$ & $-13.2 \%$ \\
10. Imperial Oil Ltd. & $\$ 25,069,000$ & $2.3 \%$ & $\$ 3,188,000$ & $4.7 \%$ \\
\hline
\end{tabular}

Note. Reprinted from Financial Post: FP 500: 2008, 2008.

\subsection{Conclusion}

Against existing interpretations of our contemporary period as a new form of imperialism, this chapter set out to explore how this period differs in its constitution of TAR in respect to capital as compared to the earlier national epoch of capitalism analyzed in chapter four. I argued that our current period can be distinguished by the emergence of a centrifugal organizing dynamic of TAR. My main claim is that as a result of the movement of the rights of capital and the authority over those rights to the transnational level, that our current period should be understood as the making of global capital; that is, as the making of an institutional infrastructure for a global system of property relations. This 
infrastructure is still in the making, but it rests on the wide variety of rights granted to capital over this period that not only force the legal institutions of member nation-states to enforce the rights of foreign firms, but restrict the governments' ability to legislate against corporate interests. The primarily role of the nation-state over this period has therefore been one of transformation from a capability for national capitals to a capability for globalizing capitals since it is increasingly oriented toward the protection the rights of global corporate private property over and against all other existing rights.

To demonstrate the empirical reality of this transformation, I provided an analysis of the transformation of Canadian banking via the history of the Royal Bank of Canada from 1975 to 2014. I identified three shifts in TAR — the movement of authority over banking to supranational institutions, financial deregulation, and free trade agreementsto represent the emerging centrifugal dynamic of TAR as it relates to the chartered banks. Through these three shifts, Canada's chartered banks gained new rights that enabled them to become huge, global financial institutions and to restrict the ability of national governments to legislate against them. I claimed that these changes are transforming the nation-state into a capability for globalizing capitals by moving the rights of capital to the transnational level. Although this process is ongoing, contingent, and subject to reversal, I believe that we should see it as an attempt to make global capital via the construction of a transnational state: an institutional structure that includes both supranational institutions and nation-states whose work is oriented toward the protection and enforcement of the rights of capital across multiple territorial jurisdictions. In the next chapter, I look at some 
emergent trends in relation to banking and finance and explore some of their political, economic, and social implications. 


\section{Emergent Trends and Implications}

All we can do is study the present epoch in an attempt to discern within it those tendencies leading into the next epoch.

—C. Wright Mills, 1962.

\subsection{Introduction}

If earlier chapters in this dissertation have been concerned with asking where we have been so as to understand where we are, then this chapter attempts to understand where we are going. In the last chapter, I attempted to demonstrate that our global epoch is characterized by an emerging centrifugal logic that is drawing particular elements of territory, authority, and rights (TAR) away from the nation-state. If, as Germain (2010) notes, "financial governance is most effective when it is organized predominantly at the national level" (p. 1) then this dynamic is representative of a worrisome trend in respect to capital's ability to escape the confines of national regulation and oversight.

In this chapter, I focus on a number of recent developments in banking and finance that are not only representative of this centrifugal dynamic, but also of where capitalist societies might be heading more generally. In particular: new forms of escape from the nation-state such as dark pools and temporary foreign worker programs; new free trade agreements, such as the Comprehensive Economic and Trade Agreement (CETA), the currently stalled Trans-Pacific Partnership (TPP), and the Trade in Services Agreement (TiSA); and new, so-called institutional technologies, such as the blockchain. 
What I want to stress, here, is that while all of these trends move elements of TAR away from the national level, this does not mean that they do not involve nation-states; in many cases, these globalizing processes were the result of nation-state regulations. The question is therefore not whether these emergent trends reduce the importance of the nation-state within the global political economy — clearly, they do not. Rather, we should ask whether they are contributing to a global property regime that works to cement the global power of capital by restricting the extent to which nation-states can legislate against it. This global property regime is still in the making; as such, the best we can do is attempt "to detect shapes and construct objects of study around what is ultimately a roving animal moving with increasing vigour and velocity" (Sassen, 2007, p. 213). The need to detect and examine these emerging shapes is extremely important, however, given their potential implications. If all human societies are defined by their respective property relations, and those relations are the result of social and political struggle, then it is the job of the critical social scientist to examine which direction these struggles are heading so as to have a better understanding of what might be their likely outcomes. The goal of this chapter is therefore to try and see the future in the present; to identify those tendencies of the new order that are not yet prevalent, but have the potential to induce systemic change.

The chapter proceeds as follows. First, I explore two contemporary means of escaping national restrictions: dark pools, and temporary foreign worker programs. Next, I explore three of the new free trade agreements, CETA, the TPP, and TiSA. I then explore the emergence of blockchain technology, a digital public ledger that eliminates the need for trusted third parties to verify transactions. In each instance, I explore how RBC is 
wrapped up in these various shifts of TAR and what they might mean for the future. I conclude by suggesting that although some of these trends are worrisome, new technologies like the blockchain might be able to provide the institutional basis for a more sustainable, post-capitalist future.

\subsection{Escape from the National}

In the literature on the global political economy of finance, a number of authors have started to highlight the extent to which shadow banking (i.e., unregulated banking activities) and tax havens constitute private spaces of autonomy that enable capital to escape national level regulations (see, e.g., Ban et al., 2016; Bryan et al., 2016; Fichtner, 2016; Lysandrou \& Nesvetailova, 2014). The historian Nils Gilman (2014) refers to this tendency as a form of 'plutocratic insurgency.' Unlike the classic 20th century insurgents, who sought to take over the state apparatus in order to implement social reforms, today's

plutocratic insurgents do not seek to take over the state. Nor do they wish to destroy the state, since they rely parasitically on it to provide the legacy goods of social welfare: health, education, infrastructure, and so on. Rather, their aim is simpler: to carve out de facto zones of autonomy for themselves by crippling the state's ability to constrain their freedom of (economic) action (p. 3).

In their quest to escape national constraints on the accumulation of capital, today's superrich seek out or create "virtual zones of legal exception in the form of offshore tax havens and special economic zones allowing them to avoid tariffs as well as laws designed to protect labour or the environment" (p. 10). Although tax havens have long been part of 
capital's circuitry, today they exist all over the world, including small jurisdictional zones within advanced capitalist nation-states. RBC, for instance, has more subsidiaries in the Channel Islands (18) than anywhere else in the world, including Canada (17). These islands are medieval territories that have been turned into global financial centres (see, e.g., Foreman, 2014). The bank also has subsidiaries in other notable offshore jurisdictions such as Geneva, Delaware, Hong King, Singapore, Dublin, and Luxembourg, along with 17 havens in the Caribbean. And while there have been some excellent studies of the offshore system (e.g., Deneault, 2011, 2015; Norfield, 2016), there has been far less discussion of some of the more obtuse means by which capital attempts to escape existing national constraints on accumulation. Let us begin with the digital: dark pools.

In her work on global cities, Sassen (2006) argues that while global financial centres such as Wall Street and the City of London are located within national territories, they should not "be seen as simply national in the historical sense, nor can they be reduced to the administrative unit encompassing the actual terrain, one that is part of a nation-state" (p. 386). This is because, in their aggregate, "they house components of the global, partly electronic markets for capital," and are thus "denationalized in specific and partial ways" (p. 386). One of those ways is through the shadow banking system, which sits just below the surface. The basic definition of shadow banking is lending or any other financial activities that are conducted by unregulated institutions or under unregulated conditions. This system is not "informal, illegal, or clandestine. It is in the open, but it thrives on the opaqueness of investments," allowing practices that might be, "after the fact, viewed as bordering on the illegal" (Sassen, 2014b, pp. 142-143). A perfect example 
is the dark pool, a "key component of the shadow banking system" (Sassen, 2014b, p. 143).

A dark pool is simply a fancy term for a private exchange. In the late 1990s and into the mid-aughts, a number of rules were changed by the American Securities and Exchange Commission (SEC) in order to help out ordinary investors. These rules essentially forced the various stock exchanges to compete against one another for orders. As Goldstein (2013) notes: "exchanges could no longer hoard orders; if a better offer existed on another trading platform, they'd have to send it there" (p. SM15). In 2005, this change was accompanied by a transformation in the classification of the American stock exchange, which "went from being utilities owned by their members to public corporations run for profit" (Lewis, 2014, p. 22). The combination of these two changes led to the creation, and subsequent proliferation, of Alternative Trading Systems (ATS) or what is more commonly referred to as dark pools.

First offered by financial giants such as Goldman Sachs and Credit Suisse, dark pools are especially notable because they all share one key component: "they do not display order size or price until after a trade has been completed" (Sassen, 2014b, p. 143). As Michael Lewis (2014) notes in his best-selling book, Flash Boys:

The amazing idea the big Wall Street banks had sold to big investors was that transparency was their enemy. If, say, Fidelity wanted to sell a million shares of Microsoft Corp.- - so the argument ran — they were better off putting them into a dark pool run by, say, Credit Suisse than going directly to the public exchanges. On the public exchanges, everyone would notice a big seller had entered the 
market, and the market price of Microsoft would plunge. Inside a dark pool, no

one but the broker who ran it had any idea what was happening (p. 26). ${ }^{140}$

The opacity of these unregulated digital territories means that there is a huge potential for abuse. Big banks have not only been caught giving unequal access to their own traders, but selling access to high-frequency trading (HFT) firms, which make money off of the nanoseconds between trades. As the rooms full of shouting traders were replaced by stacks of computer servers with matching engines connecting buyers and sellers, it was only a matter of time before the stock exchanges figured out that, if people were willing to spend hundreds of thousands of dollars to move their machines around inside some remote data center just so they might be a tiny bit closer to the stock exchange, they'd pay millions to be inside the stock exchange itself (Lewis, 2014, p. 36).

The sale of these highly-valued locations inside the exchange are now referred to as 'proximity services,' and they provide a good example as to the extent to which private property, and thus, capital, can be constitutive of forms of space.

Dark pools are now a ubiquitous feature of the global financial system as a means of escaping transparency and regulation: "today it's not just the familiar New York Stock

140 Sassen (2014b) provides another description: "In a public exchange with an open order book, the presence of a larger order can immediately move the price of a stock (for example, if ABC Co. has an average trading volume of 1 million shares a day, and there is an entry placed in the order book to buy 500,000 shares, it's an easy bet that ABC stock is going to go up, and the price that the purchaser will have to pay likely to be higher by the time the transaction is completed.) To combat this, large investors had brokers 'work' trades, breaking large blocks of stock into smaller transactions carried out over an extended period of time. This solution was never entirely effective: it increased price volatility and transaction time, and market participants could still detect a general upsurge of demand. The introduction of computerized high-frequency trading (HFT) made the situation worse for institutional investors; algorithmic trading models could reliably detect even the most patiently distributed orders" (pp. 143144). 
Exchange and Nasdaq, but also lesser-known ones with names like BATS and Direct Edge" (Goldstein, 2013, p. SM15). Despite the basis of their initial rationale-to allow institutional investors to place large orders anonymously without displaying them to the public so as to minimize market impact costs - a recent position paper from the Ontario Securities Commission (2010) claims that dark pools are now being used for "orders of all sizes, small or large" (p. 5). Dark pools thus represent a private global space in which even the information about what is going on in the financial system is hidden from the gaze of the nation-state, even as it provides the very regulations and rules that allow them to exist.

HFT firms are, like dark pools, the curious result of the way in which regulations meant to deal with the contradictions of capitalism sometimes provide new, contingent avenues for accumulation. In 2005, the SEC passed the Regulation National Market System (often referred to as Reg NMS), which required brokers to find the best market prices for the investors they represented: "the regulation had been inspired by charges of frontrunning made in 2004 against two dozen specialists on the floor of the old New York Stock Exchange — a charge the specialists settled by paying a $\$ 241$ million fine" (Lewis, 2014, p. 52). Reg NMS massively increased the significance of HFT since it forced brokers to find the best price for their investors-prices always offered by HFT firms. The combination of HFT firms and dark pools has thus played a massive role in distorting financial markets, which is no small matter given that "by the middle of 2011, roughly $30 \%$ of all stock market trades occurred off the public exchanges, most of them in dark pools" (p. 60). Furthermore, as Sassen (2014b) notes, the opacity of dark pools has made 
possible new forms of financial abuse: big banks that run their own dark pools give do not just give their own traders unequal access, but many have been caught "running the same HFT strategies within their exchanges and sharing confidential trade information with investors" (p. 145).

As Canada's largest bank, $\mathrm{RBC}$ has decided to plug itself into the world of dark pools and HFT in order to compete against other globalizing capitals. The bank's failed merger bid with the Bank of Montreal in 1998 caused RBC to reorient its strategy around the North American market. As part of that process, they were able to acquire a small U.S. electronic trading firm—Carlin Financial—in 2006 for $\$ 100$ million. One of RBCs traders, Brad Katsuyama, discovered that when he used Carlin's software his trading screens did not match the market price:

Before RBC acquired this supposedly state-of-the-art electronic trading firm, his computers worked. Now, suddenly, they didn't. Until he was forced to use some of Carlin's technology, he trusted his trading screens. When his trading screens showed 10,000 shares of Intel offered at $\$ 22$ a share, it meant that he could buy 10,000 shares of Intel for $\$ 22$ a share. He had only to push a button. By the spring of 2007, when his screens showed 10,000 shares of Intel offered at \$22 and he pushed the button, the offers vanished. In his seven years as a trader he had always been able to look at the screens on his desk and see the stock market. Now the market as it appeared on his screens was an illusion (Lewis, 2014, p. 20).

Through a process of trial and error, Katsuyama figured out that in the time it took for him to execute a trade (i.e., to push a button) that someone else was already front-running 
the stock: "it was as if someone knew what he was trying to do and was reacting to his desire to sell before he had fully expressed it" (p. 21). Over time, Kastuyama would uncover the cause: HFT.

HFT was introduced to the Canadian market in 2009, after CIBC sublet its license on the TSX to a number of HFT firms (Shecter, 2012). Within months, the bank was seeing "its historically stable 6-7\% share of Canadian stock market trading triple" (Lewis, 2014, p. 31). As a result, American HFT firms began to fly to "Toronto with offers to pay Canadian banks to expose their customers to high-frequency traders" (p. 31). Not wanting to be outdone, senior managers at $\mathrm{RBC}$ argued that they should create their own dark pool, "route their Canadian stock market orders into it, and then sell to high-frequency traders the right to operate inside the dark pool" (p. 31). The idea was killed by Katsuyama, who argued that it made more sense to "expose the new game for what it was" (p. 31). He subsequently created a new software program for RBC called THOR that foiled high-frequency traders by creating a delay on stock market order. ${ }^{141}$ The software was so successful in thwarting HFT firms that it moved RBC from number 19 in 2009 to number one in 2011 on Greenwich Associates' stock market rankings (Lam \& Alexander, 2014).

Lest the reader think this is a tale of 'RBC nice'-the culture of the bank as described by Lewis (2014) - saving Wall Street, the success of THOR more practically demonstrates the changing territoriality of global capitalism, where financial firms sell rights of access to both material and digital spaces for the purposes of extracting rent. While the world's banks have so far been extremely quiet about the amounts of money

141 Katsuyama has since left RBC to start his own dark pool, IEX, based on similar delay tactics as THOR (Erman, 2013). 
they make off dark pools, Katsuyama claims that their use is "industry wide. It's systemic" (p. 46). Lewis (2014) notes that from 2006 to 2008, HFTs "share of total U.S. market trading doubled, from $26 \%$ to $52 \%$ - and it has never fallen below $50 \%$ since then" (pp. 57-58). The total trades per day has also risen from 10 million in 2006 to just over 20 million in 2009. A writer for The New York Times similarly notes that "by 2009, high-frequency traders were making billions of dollars a year, and their transactions accounted for about $60 \%$ of U.S. stock trades" (Goldstein, 2013, p. SM14). These figures are confirmed by Sassen (2014b) who points out that dark pool trading represents close to $13 \%$ of all stock market action around the world and that "their numbers are increasing" (p. 144).

In Canada, only about $5 \%$ of trading activity occurs in dark pools as compared with over 50\% in the United States (Corcoran, 2015). This low number is the result of new rules introduced by the government via the Investment Industry Regulatory Organization of Canada (IIROC), which regulates investment dealers and trading activity in the debt and equity markets across Canada. In 2012, the IIROC introduced new rules for dark trading in shares of inter-listed stocks; in other words, the 330 stocks listed on both the U.S. and Canadian stock exchanges, representing at least $50 \%$ of the Canadian market. The rules were designed to discourage Canadian investment dealers from funnelling all their share transactions through dark pools by giving visible orders priority; while smaller retail orders can still be routed through dark pools, they need to show an improvement in the quoted price of at least half a cent per share. 
To make sure that Canadian orders are not routed to U.S. dark pools, the IIROC is proposing a "Dark Rules Anti-Avoidance Provision" that would limit dealers' ability to do so. As could be expected, the chartered banks are against the proposed set of rules that would put them at a serious disadvantage as compared to their American rivals, where dark pools provide an important source of liquidity. Scotiabank has called the proposed rules an attempt "to prop up marketplaces with protectionist regulations" (Corcocan, 2015, para. 16); CIBC World Markets has said that they are "akin to the creation of a non-tariff barrier to trade" (para. 18); and in their typically 'RBC Nice' way, RBC Capital has said that "while well-intentioned . . . the proposed rule changes constitute a blunt tool" (para. 17).

There are also more explicit, material means of escape that RBC participates in, along with other sectors of globalizing capital. As Wood (2007) notes, financial capital often has a difficult time separating itself from the more mundane realities of flesh and blood. A good example is Canada's Temporary Foreign Worker Program (TWFP). First created in 1973 to bring in high-skilled workers to Canada such as specialist doctors, the program was expanded in 2002 to include a low-skilled worker category. The total number of temporary foreign workers (TFW) in Canada doubled between 1993 and 2013 to 338,189 workers (Pfeffer, 2013) and from 2006 to 2014 more than 500,000 TFWs have been brought into Canada under the program (Wingrove, 2014). Despite having the same employment rights as Canadian citizens, TFWs are often treated far worse than their Canadian counterparts since their residency is tied to their employer. It is also against federal rules to bring in TFWs if Canadian workers are available for the same job. Even 
with these limits, RBC, along with 33,000 different companies and agencies from across all sectors of the Canadian economy, have applied to bring in TFWs as part of the program (Robertson et al., 2013).

In the case of RBC, they contracted iGate Corp. to handle the outsourcing of specific technology jobs. To add extra salt to the wound, RBC actually expected their Canadian workers to train the very staff that were going to replace them (Tomlinson, 2013). While public outcry has since forced the federal government to amend the rules of the program slightly, pro-business groups continue to argue that attempts to amend the program are "purely political and completely impractical" (Cohen, 2013). They are political and impractical from their perspective because they allow capital to essentially escape the basic rules of the game, which include significant regulations on labour gained over years of class struggle. Programs like the TFWP are thus demonstrative of the extent to which the growth of capital is now constrained by the mere existence of a national labour market, a feature that was once necessary (and, in fact, created by legislation) for the growth of the national economy. At the national level, the federal government is thus confronted with a relatively mobile, and increasingly transnational, form of capital that demands the right to cheap labour, independent of the jurisdiction. The result is a program like the TFWP that allows capital to have relatively quick and easy access to flexible, cheap labour for the purpose of extracting greater surplus than is possible within the confines of national labour delimitations.

These changes end up producing new forms of territoriality constituted "through the development of new jurisdictional geographies" that rely on the earlier framework for 
rights and guarantees that was "developed in the context of the formation of national states" (Sassen, 2006, p. 388). In our present epoch, however, these instruments work to strengthen a global organizing dynamic by not only altering the valence of older nationstate capabilities, but by sometimes pushing "national states to go against the interests of national capital" (p. 388). This can happen, for instance, when the largest firms are allowed to purchase cheaper labour from abroad while smaller businesses operating at only the national or local scale have to rely on higher-paid domestic labour, thereby reducing one aspect of their competitiveness.

Escape from the national can also be seen in the increasingly illicit activities that have become a normal part of the workings of the global financial system. In 2012, for instance, RBC was accused by U.S. regulators of orchestrating a complex 'wash and trade' scheme that allowed them to earn Canadian tax credits by purchasing dividendpaying stocks in the United States and Canada (Robertson \& Kiladze, 2012). That same year, $\mathrm{RBC}$ was also charged with manipulating interest rates as part of the London Interbank Offered Rate (LIBOR) scandal (“RBC among nine,” 2012). This manipulation enabled RBC, along with other global banks, to make millions from financial derivatives. Derivatives are a complex form of debt that derives its value from another source, "ranging from other types of debt to material buildings such as buildings and crops" (Sassen, 2014b, p. 117). Since the value of a derivative depends on the prevailing rate of interest, which is commonly calculated on the basis of the LIBOR (Lapavitsas, 2013, p. 9), the conflict of interest should be clear. At almost every turn, the tendency today is toward escaping national restrictions on their accumulation activities; that is, unless they are able 
to restrict the nation-state from having the ability to do so. Enter the new free trade agreements.

\subsection{The New Free Trade Agreements}

The astute reader will note that I have been somewhat reticent to talk specifically about the ways in which Canada fits into or is effected by this emerging centrifugal dynamic. While I have certainly been clear that this movement increasingly reduces the meaning and efficacy of Canadian liberal democracy, I have said less about where Canada is going and what we might expect of the country in the years to come. To explore those questions, let us begin by reflecting on some of the larger shifts from the political economy of Canada's past. This will help make clearer some of the epochal-level changes that are occurring today by way of the new free trade agreements.

While foreign direct investment (FDI) and Canadian direct investment abroad (CDIA) have long been a barometer of Canada's 'location' in the global political economy, theories of Canadian imperialism and dependency have said far less about the qualitatively different nature of these flows today. Not only have FDI and CDIA tripled since 1996, but the main sectors for investment both abroad and in Canada are in finance, insurance, and management, not branch-plant manufacturing, as was the case historically. In 2012, for instance, $52.9 \%$ of total CDIA was in the finance, insurance, and management industries, followed by the mining, oil, and gas extraction sector at $18.8 \%$ :

Meanwhile, the share of investment in manufacturing fell below $10 \%$ for the first time, continuing a decline which has seen that sector's share of Canadian 
investment abroad decline from a peak of $31.9 \%$ in 2000 . The finance, insurance and management industries also accounted for a significant share of foreign direct investment in Canada with 32.6\% of total investment in 2012. The manufacturing sector remained a significant destination of foreign direct investment in 2012 with a $28.7 \%$ share, while the mining and oil and gas extraction industry accounted for a further 19\% (Statistics Canada, 2013, May 9).

While direct investment (in and out) remains tied to the United States, the United Kingdom, and Europe, it is important to note that the next highest amount of outgoing FDI is invested in known tax havens. These transformations certainly lend credibility to Klassen's (2009) argument that the circuits of capital in Canada mirror the wider globalization and financialization of the circuitry of capital at the world scale. His claim that foreign ownership of Canadian assets and revenues remains low by both historical and comparative standards also holds true: in 2009, foreign ownership of Canadian assets and revenues was $19.7 \%$ and $28.9 \%$ respectively (Statistics Canada, 2011, Oct 13). It is not clear, however, how any of these shifts are evidence of Canada's place within the socalled 'new imperialism,' as he suggests. Instead, they seem to indicate that there is a much larger transformation of the global political economy taking place. As such, it might be useful to once again reflect on what RBC has been up to in the years since 2014, the date in which this dissertation ends.

In the years following 2014, RBC has shifted their focus toward "high net worth and ultra-high net worth clients in key areas of expansion, including Canada, the U.S., the British Isles and Asia" (Canadian Press, 2014). The move reflects a more significant 
global shift in class composition as expressed in a 2005 memo from Citibank. In that memo, Citibank argued that the world was being divided into two blocs: "the plutonomies, where economic growth is powered by and largely consumed by the wealthy few, and the rest" (Kapur et al., 2005, p. 1). The memo projected that the key plutonomies — the United States, the United Kingdom, and Canada—would likely see "even more income inequality, disproportionately feeding off a further rise in the profit share of their economies, capitalist-friendly governments, more technology-driven productivity, and globalization" (p. 2). No longer made up of national consumers, plutonomies are divided between the rich, "few in number but disproportionate in the gigantic slice of income and consumption they take" and "the rest, the 'non-rich,' the multitudinous many" that account for "surprisingly small bites of the national pie" (p. 2). Citibank's advice for their wealthy clients was not to worry, since "the plutonomy is here, is going to get stronger, its membership swelling from globalized enclaves in the emerging world" ( $p$. 2). They recommended that "a 'plutonomy basket' of stocks should continue to do well. These toys for the wealthy have pricing power and staying power" (p. 2).

RBCs post-2014 strategy confirms the unfortunate reality of Citibank's memo. Shortly after the bank's official year-end on October 21, 2015-a year in which the Royal earned record profits of $\$ 10$ billion-it took possession of City National, Hollywood's banker to the stars. Well established in New York, Los Angeles, and San Franscisco, the acquisition of City is a hedge against slumping oil prices "in the face of withering growth prospects at home" (Trichur \& Steinberg, 2015, para. 1). Indeed, as Shannon Daub and Bill Carroll (2016) note as part of the Corporate Mapping Project, with the exception of 
the three major private oil companies (Nexen, Talisman/Repsol, Shell Canada), RBC has an ownership stake in every single one of the other 12 publicly-traded companies (all of which are predominantly foreign owned) operating in Alberta's Tar Sands. As such, it's not surprising that $\mathrm{RBC}$ is "anxious for a return to a booming Canadian oil and gas sector" (para. 6).

In referring to the bank's move into the high-end market (a clear hedge against low oil prices at home) RBCs current president and CEO, Dave McKay states: "the combined high-net population of these three markets [New York, Los Angeles, San Franscisco] is over $4 \frac{1}{2}$ times the entire high-net-worth population of Canada (Pittis, 2015, para. 16). $\mathrm{RBC}$ is also looking to move into "other places with a lot of rich people such as Houston and London" (para. 17). Here's the rub, however: at the same time that RBC is betting against the Canadian economy, it is also the largest asset in most Canadian stock portfolios, including the Canadian Pension Plan investment fund (worth over $\$ 1$ billion) and the Quebec Pension Plan (\$1.3 billion worth of RBC shares), meaning that many Canadians are being forced to bet on a similar collapse, albeit, one that will affect them disproportionately, since RBC is now too big to fail. Indeed, at the RBC Capital Markets Canadian Bank CEO Conference in Toronto, RBCs CEO Dave McKay argued that it was unlikely for there to be a housing crisis in Canada similar to that in the United States since "higher interests rates are only likely if the overall economy is doing well [hint: it is not]" (Schecter, 2017, para. 4). Besides, added BMO CEO Bill Downe, people only walked away from their mortgages in 2008 "when they lost their jobs, got a divorce, or if 
the value of their home fell to $60 \%$ or less than the mortgage" (para. 6). Comforting words.

As RBC and the other banks attempt to hedge their bets against a continuously slumping Canadian economy by moving upwards to the rich as well as abroad, we should do well to take note of the new institutional framework that allows them to do so. The emergence of a variety of new free trade agreements represents a significant attempt to restrict the nation-states ability to regulate or constrain globalizing capital. Take, for example, the Comprehensive Economic Trade Agreement (CETA) signed by the Harper government and the European Union in 2013 and passed by the Trudeau administration in 2016 - a process ironically negotiated by then Liberal Minister of Trade Chrystia Freeland, author of Plutocrats: The Rise of the New Global Super-Rich and the Fall of Everyone Else. Supported by the Canadian Bankers Association, and thus, all of Canada's major banks, CETA is similar to NAFTA in that it utilizes existing national legal systems to protect and enforce global corporate private property. It does this by giving European firms operating in Canada (and vice versa) new rights to launch legal challenges against Ottawa over regulatory changes that inhibit their ability to accumulate capital. These challenges not only bypass the legal system of the host country, but are decided by secret tribunals made up of corporate lawyers and judges. Since Canada has already been subject to 35 of these challenges under NAFTA, we should expect this number to rise substantially. 


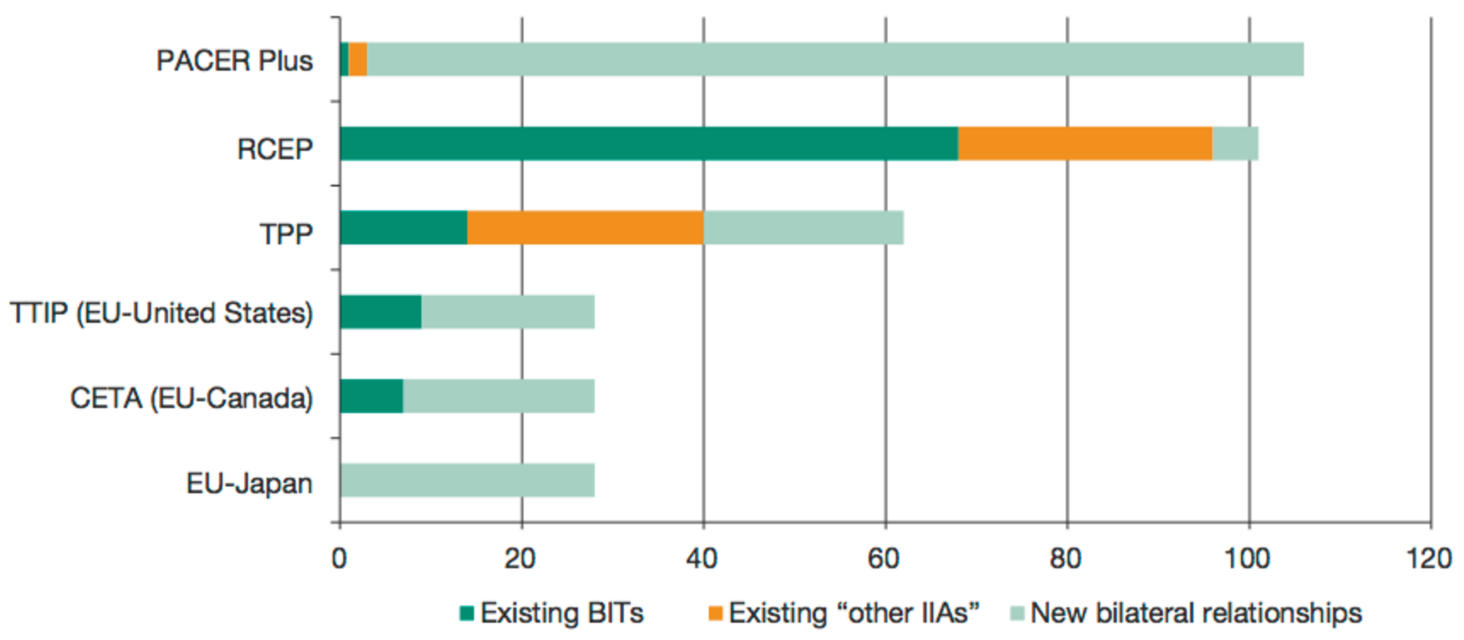

Figure 4. Existing International Investment Agreements and New Bilateral Relationships Created, for Six Megaregional Agreements. BIT refers to Bilateral Investment Treaties. IIA refers to International Investment Agreements. Reprinted from UNCTAD: World Investment Report 2014, 2014. Copyright 2014 by UNCTAD. Reprinted with permission.

We can expect this because CETA goes much further than NAFTA as an instrument of corporate power. Covering a significantly broader range of investor protections, the agreement gives European banks the right to sue the Canadian government if they believe that they are being discriminated against relative to other Canadian or foreign investors. They can also sue on the broader basis of not being offered fair and equitable treatment. With the potential to win millions or even billions, if they succeed, there is little chance that Canada's state managers fail to take account of this when drafting financial policy. As international investment law professor, Gus Van Harten, notes: "with billions of dollars at stake, you're going to think very carefully about what an unknown trio of arbitrators is going to do with the fair and equitable treatment clause as applied to the financial sector" (as cited in Whittington, 2014, para. 15). While the government has so far been able to negotiate a 'carve out' that allows them to preserve the widely-held own- 
ership rule (thus barring direct foreign takeovers of Canada's banks) as well as their ability to regulate the financial sector, this provision only goes so far as is necessary to stabilize the Canadian financial system. To do so, the government must first demonstrate "before a 'financial services committee' that its actions were indeed to reduce risks and contagion, rather than a back-door to restriction competition" (Beltrame \& Blanchfield, 2013, para. 18). Unless that committee comes to a consensus that "the government's use of prudent measures was legitimate and therefore not a breach of the foreign investors' rights (Whittington, 2014, para. 19) then the case moves forward to a secret tribunal.

As instruments of corporate power, so-called free trade agreements like CETA are used to restrict the ability of nation-states to regulate the activities of TNCs, no matter where they are based. Although these agreements have so far been limited to regional blocs, larger more wide-ranging agreements such as the now-stalled Trans-Pacific Partnership (TPP) and the Trade in Services Agreement (TiSA) seek to continue the trend of creating megaregions, but on a much larger scale. ${ }^{142}$ Put simply, these agreements are the institutional and political mechanisms to consolidate a system of global corporate private property. They essentially function as a supra-constitution to defend the freedom of corporate actors against democratic attempts to challenge their right to devastate the environment and privatize social services. Given the claims made in her recent book, Mrs.

142 The countries involved with the now-stalled TPP are: Australia, Brunei, Canada, Chile, Japan, Malaysia, Mexico, New Zealand, Peru, Singapore, the United States, and Vietnam; although the United States has recently withdrawn. The countries involved with TiSA are: Australia, Canada, Chile, Taiwan, Colombia, Costa Rica, Hong Kong, Iceland, Israel, Japan, Liechtenstein, Mexico, New Zealand, Norway, Pakistan, Panama, Paraguay, Peru, South Korea, Switzerland, Turkey, the United States, and the European Union, which includes its 28 member states Austria, Belgium, Bulgaria, Cyprus, Croatia, Czech Republic, Denmark, Estonia, Finland, France, Germany, Greece, Hungary, Ireland, Italy, Latvia, Lithuania, Luxembourg, Malta, Netherlands, Poland, Portugal, Romania, Slovakia, Slovenia, Spain, Sweden, and the United Kingdom. China and Uruguay have also expressed interest in joining, but have so far not been included in negotiations. 
Freeland (2012) should be well aware that these agreements are how the plutocrats secure their power and wealth. The TiSA, for instance, would not only prohibit any restrictions on the size, expansion, or entry of financial companies, but would also ban any new regulations, including a specific ban on any law that separates commercial and investment banking (Dolack, 2017). The agreement also bans restrictions on the cross-border transfer of personal and financial data.

It is little surprise that Canada's chartered banks support such agreements. Indeed, a report from the Bank of Montreal notes that if the TPP were to go forward it would not only improve their access to high-growth markets in Asia such as Malaysia, Vietnam, and Singapore, but "temper the dominance of state-owned enterprises in banking and insurance" (Chen et al., 2015, p. 9). In combination with NAFTA and CETA, this would mean that Canada's corporations would enjoy preferential access to almost $90 \%$ of its export markets and be the only G7 country to have free trade access to the United States, Europe, and the Asia-Pacific region. This is no small matter given that the export of Canadian financial services has more than doubled over the past decade (Sutherland, 2014). While the new American President, Donald Trump, has proclaimed the TPP dead, it remains to be seen whether it will remain dead; especially given the gains to be had by the world's corporate sector. As should be clear, however, these agreements do nothing other than move the rights of capital to the transnational level; in doing so, they reduce the means by which the nation-state can be used to challenge capital's inherent drive to turn the entire world into a single, unified market. 


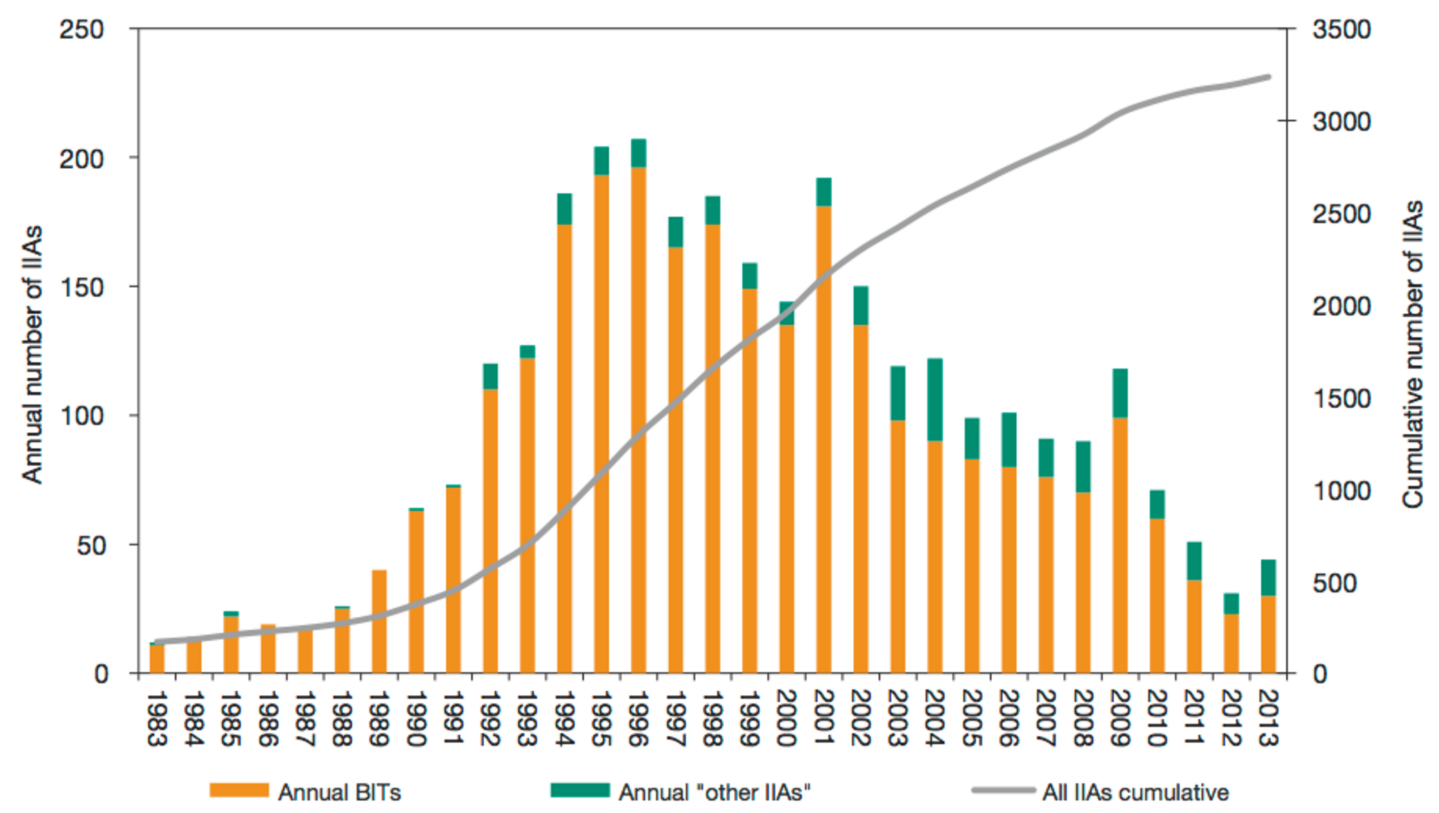

Figure 5. Trends in International Investment Agreements Signed, 1983-2013. BIT refers to Bilateral Investment Treaties. IIA refers to International Investment Agreements. Reprinted from UNCTAD: World Investment Report 2014, 2014. Copyright 2014 by UNCTAD. Reprinted with permission.

\subsection{The Blockchain: An Institutional Technology}

A further example of the centrifugal dynamic of our epoch can be seen in some of the new technologies being developed and used by the financial sector; in particular, the blockchain, which has the potential to transform not only the financial system, but the entire global political economy as well. Indeed, in a private report, Goldman Sachs claims that "the blockchain could disrupt everything" (Boroujerdi \& Wolf, 2015, p. 3). Some economists have even started to refer to it as a "new 'institutional technology' that enables a new social order to unfold" (Tasca \& Ulieru, 2016, p. 10).

At its simplest, the blockchain is a digital ledger of transactions that is distributed and verified by an entire network of decentralized computers. First emerging in the wake of the 2008 financial crisis as the software underpinning the cryptocurrency Bitcoin, the 
blockchain's fundamental innovation is that it allows for 'trust-less' transactions; that is, it records and stores every transaction on the network itself, eliminating the need for a trusted third party such as a bank to verify a successful transaction. While the simplest use for the blockchain is for peer-to-peer (P2P) transactions of data, when combined with 'smart,' automatically-enforced contracts, the potential uses expand exponentially. Now, two or more parties can make agreements, with funds paid out automatically after the terms are met. After buying a stock, for instance, the trade could be settled and the shares instantly transferred. Or, when a contractor delivers a product that meets specifications, they are paid automatically. The latter is the basis for the Ethereum Project's attempt to re-architect the corporate form through the decentralized autonomous organization (DAO), which is essentially a digital corporation owned by its shareholders who vote on proposals as to how its funds are spent. As a result, firms both large and small have rushed into blockchain technology, with investment increasing from $\$ 3$ million U.S. in 2011 to $\$ 474$ million in 2015 (Smith, 2016b).

For many, the blockchain represents the beginning of a technological revolution in which self-driving cars own themselves (Vigna \& Casey, 2015), homes are equipped with blockchain-powered 'smart locks' (Buterin, 2015), and semi-autonomous devices order 
their own supplies and perform their own maintenance (Higgins, 2015). ${ }^{143}$ Some have

even gone so far as to suggest that the blockchain could free humanity from the power of

large centralized institutions such as the corporation and the nation-state (Frank, 2015).

As I note elsewhere, however, these claims are problematized by the fact that the world's

largest financial firms are some of the biggest investors in blockchain technology (Gar-

rod, 2016). RBC, for instance, is part of a group called R3CEV that now includes 75 of

the world's largest banks working to bring the blockchain to global financial markets

(Kelly, 2015). They are also working on a new proof of concept for a blockchain-based

remittance system (Rizzo, 2016). These developments would essentially allow the banks

to replace their old, legacy IT structures that have been cobbled together over the last few

143 Vitalik Buterin (2015), the founder of Ethereum, gave an example of what this future might look like at a talk at the Swiss Institute of New York: "You wake up, and see that \$17.27 was automatically deducted from your primary wallet, as you had authorized to happen every day, to pay the rent for your apartment; if you canceled the authorization, then, after a warning period, ownership in the land-registry contract would automatically transfer back to the landlord, and the door lock would no longer recognize signatures signed by your smartphone's private key as valid for letting you in. Of course, your landlord is bound by the same restrictions. If he shuts off his account that pays the local government \$6.60 land-value tax per day, then he loses ownership and the contract automatically switches over so you are renting from the government instead. The government itself is simply a large decentralized organization, and you can see in real time the $\$ 6.60$ moving on the blockchain and eventually getting into an account to pay for a medical-research program trying to extend the human lifespan from 170 years to 230 . The Internet that you are using to access this information is based on a decentralized and incentivized mesh-networking platform; you paid $\$ 0.0009$ to access the information, but your laptop also earned \$0.0014 transmitting other people's packets at the same time. You get into your Mastercar self-driving car to go to work (originally, all self-driving cars were made by Google, but Master Corporation, a decentralized autonomous entity that automatically uses a combination of futarchy and liquid democracy to determine how the company should spend its funds each day, proved that its governance mechanism was so efficient that it overtook Google on some core services within three years, and alt-Mastercorps took over most of its other operations). You get in, and Mastercar runs a optimized version of the A* search algorithm (for which James Wilbur automatically got a bounty of \$782,228 worth of MSC from the Master Contract) to determine the optimal path to your primary workplace. Given that your self-tracking app has detected that you value your own time (or, rather, the delta between time spent in a car versus time spent at home or work) at an average of \$14.18 per hour, the Mastercar's algorithm chooses a route that takes an extra eleven minutes in order to avoid road tolls and also on the way moves a shipment from one side of the city to the other. You drive out, and thirty minutes later you have spent \$1.04 on electricity for your car, \$1.39 on road tolls, but receive a reward of \$2.60 for moving the shipment over. You arrive at work - a location which is a hybrid living/working space where 'employees' of five different alt-versions of Master Corporation are spending most of their time, ex- cept that you chose to live at home because you have a family. You then get to work, running simulations of a proposed new scalability algorithm for the now community/DAO-driven Ethereum 6.0." 
decades with new platforms that would enable them to exchange assets automatically and instantaneously. At present there are already 400 blockchain start-ups working on products for the financial service sector, with $\$ 290$ million (U.S.) invested in the first six months of 2016 alone (Wild, 2017). What this means is that we might soon live in a world in which the property relations of capitalism are supported by digital, automatically-enforced contracts.

Using language similar to their earlier conflict with the near-banks, RBCs CEO Dave McKay (2015) defends their investments in these new technologies as a means of repositioning themselves in a mobile society, enabling them to "compete with technology firms that have expanded into the money moving business, and yet who do not bear the financial and social costs of a deposit-taking organization — or the obligations of financial regulation" (para. 88). McKay continues noting that while "many of these new entrants are excellent competitors-innovative, driven, and responsive to their clients," that they may also "distort the financial system with unintended risks that regulators cannot clearly see" (para. 88). McKay's comments are fairly ironic given the extent to which dark pools have been proven to significantly distort markets.

As business journalist Tim Kiladze (2014) notes, the real reason why technology firms are moving into the money moving business is because they are struggling to make money: "Amazon, for instance, lost \$437-million (U.S.) last quarter, despite having a reputation as a digital-retailing genius (para. 8). In contrast, Canada's chartered banks collectively earned $\$ 33$ billion in 2014, "making financial services seem like a profit oasis" (para. 8). The move into new technologies like the blockchain is thus less a means of 
positioning the bank in a mobile society, and more a means of massively reducing their overhead through the automation of a number of different social processes relating to the exchange of money and other assets across national borders. By automating contracts related to the sale and exchange of assets, financial institutions will be able to layoff a significant portion of their employees. 
Table 11

World's Largest 25 Banks, 2015 (composite score of revenues, profits, assets, and market value)

\begin{tabular}{|c|c|}
\hline Bank & Country \\
\hline 1. ICBC & China \\
\hline 2. China Construction Bank & China \\
\hline 3. Agricultural Bank of China & China \\
\hline 4. Bank of China & China \\
\hline 5. JP Morgan Chase & U.S. \\
\hline 6. Wells Fargo & U.S. \\
\hline 7. HSBC Holdings & U.K. \\
\hline 8. Citigroup & U.S. \\
\hline 9. Bank of America & U.S. \\
\hline 10. Banco Santander & Spain \\
\hline 11. Mistubishi UFJ Financial & Japan \\
\hline 12. Bank of Communications & China \\
\hline 13. Itaú Unibanco Holdings & Brazil \\
\hline 14. Commonwealth Bank & Australia \\
\hline 15. Royal Bank of Canada & Canada \\
\hline 16. China Merchants Bank & China \\
\hline 17. Westpac Banking Group & Australia \\
\hline 18. Banco Bradesco & Brazil \\
\hline 19. TD Bank Group & Canada \\
\hline 20. UBS & Switzerland \\
\hline 21. Industrial Bank & China \\
\hline 22. ANZ & Australia \\
\hline 23. Sumitomo Mitsui Financial & Japan \\
\hline 24. China Misheng Banking & China \\
\hline 25. National Australia Bank & Australia \\
\hline
\end{tabular}

Note. Reprinted from Forbes 2015 Global 2000: The World's Largest Banks, by Liyan Chen, 2015. 
The importance of this shift, of course, has to do with the implications for the rest of us, the multitudinous many. As Kiladze (2014) notes, Canada's banks are crucial to Canada's stock market, with the six largest lenders constituting " $22 \%$ of the entire S\&P/ TSX Composite Index — more than all the energy companies combined — and our financial institutions are widely held in everything from pension funds to RRSP accounts" (para. 15). Their move into new technologies like the blockchain is therefore likely to have a great effect on all of us; and it might not be very pretty. Some legal scholars note, for instance, that if blockchain technology was taken over by big corporations, financial institutions, or the nation-state, that it might "lead to the establishment of a totalitarian society that is (almost exclusively) regulated by self-enforcing contracts, which establish the rules that everyone must abide by without any constitutional constraints" (De Filippi, 2014, para. 35). It is in this sense that some legal scholars have referred to the blockchain as a regulatory technology "that can be used to both define and incorporate legal or contractual provisions into code, and to enforce them irrespectively of whether or not there subsists an underlying legal rule" (De Filippi \& Hassen, 2016, p. 9).

The problem, however, is that much of this is already happening. Rather than creating a large public blockchain (which was the initial purpose of the software as it exists in Bitcoin) the world's largest banks have been working to create their own private blockchains that will allow them to reduce their costs while retaining control over the financial system-remember, that the blockchain essentially removes the need for banks and other financial institutions at all. While it still remains to be seen how all this will 
play out, the influence of globalizing capital on these developments is a worrying trend to say the least. Insofar as this technology increases the mobility of capital across borders, it will therefore continue to change the relationship between capital and the nation-state; in particular, the ability for the nation-state to restrict the accumulation of capital. The blockchain might not only make possible a world of instant and automatic borderless transactions, but one in which the very means of enforcing those contracts is done automatically via code (whether legal or not). As capital increasingly gains the means to enforce and protect the very property relations that sustain it through the blockchain, we might be forced to ask in the near future whether this so-called institutional technology represents the emergence of a digital state. For now, however, this is speculation. In any case, the shift in rights that the blockchain represents (from rights enforced by governments to rights enforced by code) signifies an important development that may soon come to represent one of the most elemental features of our epoch.

\subsection{Conclusion}

In this chapter, I explored some of the emergent trends and implications of ongoing shifts to TAR that are representative of the centrifugal dynamic of our age; in particular, new forms of escape from the nation-state such as dark pools and temporary foreign worker programs; new free trade agreements, as as CETA, the TPP, and the TiSA; and the blockchain. While capital's attempts to escape and evade national restrictions have real world consequences for billions of people, they are mirrored by a larger attempt to move the rights of capital upward, away from the reach of national politics. In this context, we 
are forced to ask, as Deneault (2011) does: "who leads? Who decides?" (p. vii). Much of the regulation of Canadian banking, for instance, exists at the supranational level, the result of private negotiations between governments, supranational institutions, and the chartered banks. There is little, if any, input from the public into these rules and regulations that end up working to support and reproduce the accumulation of capital on an ever-increasing scale. If something is not done to restrict the rights of capital, we are asking for the further subjugation of our civil, political, and social rights, not to mention, the potential for total and utter ecological collapse.

While there is an overwhelming sentiment today that technology will be able to save us from ourselves, it would be wise to be critical of this utopian narrative, especially insofar as those technologies, like the blockchain, are utilized for the purpose of accumulating capital. But they need not be, necessarily. Indeed, as Ursula Franklin (1990/1999) notes: "what turns the promised liberation into enslavement are not the products of technology per se ... but the structure and infrastructures that are put in place to facilitate the use of these products and to develop dependency on them" (p. 100). As an increasing number of scholars, activists, and technologists point out, the blockchain could also be used to leapfrog over many of the problems rife in contemporary institutions by enabling new incentive systems that differ significantly from today's market-based mechanisms (e.g., Bauwens \& Kostakis, 2016; Bollier, 2015). Primaverra de Filippi (2015) notes, for example, that new blockchain-based forms of organization, like the DAO, could enable decision-making procedures that are entirely crowdsourced, "delegating to the community's collective intelligence the responsibility to monitor and evaluate its own achieve- 
ments" (para. 5). Indeed, the blockchain could just as easily be used to create communitybased mutual-aid societies, digital community currencies, voting systems, basic income schemes, public insurance systems, and any other form of social contract that one can think of (e.g., Frank, 2015). Even business scholars agree that the technology has the potential to transform firms like Airbnb, Uber, and Facebook into digital co-operatives owned by their users (Tapscott \& Tapscott, 2016). This technology therefore has the potential within it to provide the institutional basis for a far more sustainable, post-capitalist future for all of us. Whether that happens, of course, is the real question. It is in this sense that we must, as Franklin (1990/1999) writes: "protest until there is change in the structures and practices of the real world of technology, for only then can we hope to survive as a global community" (p. 133). 


\section{Conclusion}

Corporate power is not tangential to Canadian society. Corporate power is Canadian society.

—James Eayrs, Political Scientist, 1979.

\subsection{Reflections}

In the following section, I want to reflect back on the methodology and approach used in this dissertation. My goal, here, is to inform the reader as to my thought process in crafting this study. I also aim to highlight what this process revealed over time; in other words, what was once concealed, but became revealed after undertaking this study.

When I first came to Carleton in the Fall of 2011 my intent was to study the history of the Canadian corporation. I wanted to make a relatively simple argument: that since capital was becoming global, so too was the state. At our introductory wine and cheese, I cheekily toasted that I planned to study 'the end of Canada.' While that toast got a lot of laughs, and immediately endeared me to some of the more critical members of the department, the actual effort involved in such a study turned out to be much more difficult than I originally anticipated. I recall an early meeting with Bruce Curtis where he asked me if my argument would make sense if capital was still national, and, if not, how I planned to prove that capital was global. I didn't have any good answers for Bruce, so that set me out on my initial journey to discover how one might go about labelling capital either national or global (or transnational, to use a less ambitious adjective), and which of those was a more accurate description of the type of capital that exists today in the form 
of the transnational corporation. That task led me through an analysis of the more traditional indicators of corporate nationality (and became the substance of my second comprehensive exam), as well as the many theoretical debates on the periodization of globalization. Was globalization something new, or something inherent to capitalism itself? Merely a part of the endless part of the process of self-expansion?

As I worked through those debates— tumbled, more like—one thing became very clear: by any traditional indicator, it was very difficult to label the largest Canadian corporations today (and indeed, all of the world's largest corporations) as explicitly national. The meaning of what was still national (e.g., corporate networks) was not clear either. As I argued in the first chapter, the inability to label the nationality of capital fundamentally confounds theories of Canadian imperialism and dependency, which remain tied to a conceptual framework in which nation-states act on behalf of their national capitals. In that framework, if something is nominally national, it is national; there is never any examination as to whether the term obscures more than it reveals, or what the term even refers to when put into a larger historical perspective. What makes a nation-state national?

Furthermore, as I continued my research, it was clear that there had been a number of qualitative changes that had transformed capitalism far beyond what it was when many of these theories were initially constructed. As I noted in the first chapter, today's form of global capitalism is characterized by an exponential leap in the scale of transnational corporate activity, lubricated by newly deregulated national financial systems whose almost instantaneous flows of capital make corporate nationality ambiguous at best, even in the simplest of cases. Moreover, the so-called free trade agreements that 
seemed to multiply in numbers over the last 30 years continue to provide foreign corporations the right to sue national governments for policy decisions that constrain the accumulation of capital.

Taken together, these developments seemed to indicate a very different organizing logic than that which had characterized the earlier national epoch of capitalism. I had a hard time, however, squaring my own understanding of globalization with the alternative theories of global capitalism. While I more or less agreed with their claim that globalization was a novel phase in the history of world capitalism, I was far less convinced by the evidence used to support this claim, as well as some of the conclusions drawn from it. Most of this evidence consists of attempts to demonstrate that the accumulation of capital has moved to the transnational level, and that this is the result of a transnational capitalist class (TCC) that has "directly instrumentalized" (Robinson, 2004, p. 88) supranational institutions and nation-states. This neglects, of course, that the process of capital accumulation has always been somewhat transnational (especially when one's vantage point is from Canada, a former colony) and that capitalists today remain fairly national in their networks (Carroll and Klassen, 2011). Furthermore, these theories seemed to provide very little explanation as to how previously national institutions had actually become reoriented toward global interests in the last 40 years, or how they worked together with the various supranational institutions to constitute a transnational state. The answers in this literature seemed to be that which I started with: as capital goes global, so too the state.

It was at this point in my research that it became clear that both sides of the debate were using the status of capital to make their point: if capital was proven to be na- 
tional, then contemporary events and interstate relations could be explained by theories of imperialism; if capital was proven to be transnational, then the relationship between capital and the nation-state system (i.e., the boundaries and meaning of political space) needed to be rethought. The inevitable result was that both sides simply went back and forth trying to demonstrate that production, accumulation, and class, among other categories, were more or less national, more or less transnational. In doing so, neither came close to transcending the basic antagonism between continuity or change that sits at the heart of the recent phenomenon we refer to as globalization. My objective in this dissertation was thus to set out an alternative way of conceptualizing globalization that could account for the fact that the ascendance of a new order does not necessarily mean an end to the old, but rather, a reconfiguration.

It was here that I happened to stumble across Saskia Sassen's (2006) Territory, Authority, Rights. While I knew of her work on globalization, I had read very little of it during my studies. Well, that's not entirely true. I had actually read a chapter of that book in an earlier seminar, but for whatever reason, the significance of the research didn't sink in at the time. Given my thinking then, I likely hand-waved it away as being Weberian and mumbled something about property relations. Luckily, Janet Siltanen recommended that it might be useful to start thinking in terms of assemblages and, as a result, I became reacquainted with Sassen's work, which now provided me with an alternative way of conceptualizing what these various debates seemed to be about.

As I pointed out in the second chapter, theories of imperialism and global capitalism all derive from the work of Marx, and Marx's entire theoretical and conceptual 
framework — that is, historical materialism—depends on the prevailing property relations of a social formation, which then determine the relationship between different groups (or classes) of people, the nature of their struggle over the surplus, as well as the role of political institutions, forms of authority, territorial boundaries, and so on. For Marx, property relations are simply a universal feature of social life that can be configured in different ways; as such, they express themselves in very specific, historically unique ways that have very real material consequences for the actual people living in those societies. Understood in such way, Marx saw the coming of capitalism as the long process whereby private property came to be the predominant property form, encompassing the means of production (most significantly, land). As such, those without independent sources of wealth were forced to sell their labour power to survive.

The problem with Marx's theory, however, is that he says very little about how these relationships are actually organized; in other words, why capitalism came to be organized in a system of mainly national states. Using Sassen's framework allowed me to conceptualize property regimes as assemblages of territory, authority, and rights, since any system of property relations implies a territory over which rights apply, an authority to enforce them, and a particular form of claim, entitlement, or right. And since rights are the result of social and political struggle between organized groups, which ultimately reorient the role and nature of political institutions, it followed that any examination of the largest and most powerful Canadian corporations was likely to shed some light on the ways in which globalization was transforming the role and nature of the Canadian nationstate. I could simply use Sassen's framework to compare periods within Canadian history 
in order to explore the question of whether our present epoch consists of a fundamentally different organizing logic of TAR than earlier periods, and, if so, how that might impact existing interpretations of Canadian political economy.

It was at this point that I made the decision to examine the transformation of the three largest, widely-held corporations in Canadian history, the "Canadian-owned strongholds" (Clement, 1992, p. 67) of the finance, transportation, and utilities sectors: the Royal Bank of Canada, Bell Canada Enterprises, and Canadian Pacific Railway. My initial reasoning was based not only on their historical dominance, but on the fact that their mutual histories spanned the entire length of Canadian history since Confederation. Furthermore, they continued to be at, or near the top, of their respective sectors, securing their status as national capitals. I decided to choose the case study method, rather than a more general analysis, because of the depth that case studies provide. By focusing on both the actor level and the structural level, as well as on the relation between the two, I felt that the case study method was able to transcend some of the traditional actor/structure debates that persist in Marxist thinking, as well as the social sciences more generally. Furthermore, I figured that this method would allow me to get much closer to my subject matter in such a way as to demonstrate to the reader the extent to which property relations shape and structure all manner of personal and societal interactions.

As the research went forward, however, it slowly became clear that the other cases (Bell and CPR) were not really necessary to make the argument that I sought to make. As compared with the Royal Bank, they seemed to be merely holding on against the forces of globalization, doing their best to keep their grasp on the national market as more 
mobile rivals knocked at the door (Netflix, to give but one example). As such, the project quickly shifted toward a single case study of the Royal Bank of Canada after a well-timed discussion with Janet Siltanen. To Janet's credit, that decision made more and more sense as I discovered not only the extent to which banking had transformed over the course of the last 40 years, but that this transformation was directly a result of the changing property relations of capitalism. As I demonstrated over chapters four, five, and six, the organizing dynamic of TAR that characterized the activities of the Royal were clearly changing from a centripetal dynamic that drew TAR into the national level, to a centrifugal dynamic that increasingly moves the rights of capital and the authority over those rights to the transnational level, outside the grasp of national politics. In the seventh chapter, I explored some of the emergent trends that will continue to shape capitalism for years to come and their likely implications, a point I will return to shortly in the section on future research. For now, let us examine some of the limitations of this study.

\subsection{Limitations}

The primary limitation of this study was one of data. Given the secretive nature of large corporate enterprise, getting enough data from one firm was incredibly difficult; especially when considering that I was trying to study a bank, which are not known as the most forthcoming of institutions. As I mentioned in the introduction to this study, this reality forced me to rely heavily on a number of secondary sources, such as Duncan McDowall's (1993) official history of the bank, Quick to the Frontier. I was also forced to rely on a number of secondary statistics because I was either not able to find similar data 
myself, or did not have access to it (increasingly, data on corporations is held in databases owned by large financial firms; according to the Carleton librarians I spoke to, access to some of these databases is so expensive that not even the largest Canadian universities can afford them). That said, as I also pointed out in the introduction, this reality is one shared by all contemporary studies of the Royal Bank of Canada. Despite the outcome, it was nice to know that I was not alone in my struggle to gain access to this type of data. I should also mention, here, that while I understand that statistics help the reader to situate the size and growth of the Royal over time, I had initially made a conscious choice not to include any statistics so as to force the reader to focus more closely on the qualitative changes that were constituting our emerging global epoch. I now realize, however, that these statistics are helpful for those readers that do not share a historical understanding of the subject matter at hand and plan to include them in future studies insofar as they are relevant.

A secondary limitation of this study is one shared by all single case studies; that is, the extent to which one can make generalizable claims on the basis of a single case. This reality is compounded by the fact that much of what I discuss in the dissertation is specific to Canada; for example, particular legislation. Single case studies therefore run the risk of missing other things in the landscape; their focus on depth comes at the expense of breadth. That said, as I mentioned above, this dissertation initially consisted of three cases (which I plan to return to in the future) whose inclusion eventually seemed unnecessary to make the theoretical argument I sought to make (that globalization is a novel epoch). There is no doubt, however, that the general claim that I am making will 
look different from the perspective of other countries. One clearly cannot make the claim that China, for example, is undergoing the exact same transformation of TAR as is Canada at this moment. The benefit of my approach, however, is that it can be applied to any period of time and any particular place. While some of the shifts I mention may not be occurring elsewhere, which ones are? And why? Just as the emergence of the nation-state was an uneven development across the world, research seems to indicate that the emerging centrifugal dynamic of our epoch extends far beyond Canada, alone. Further research will need to be done to examine just how far it goes and what role certain events might play in returning us to a centripetal logic.

A third limitation of this study is the level of analysis. While case studies can do well to transcend some of the more significant debates about actor/structure, my analysis only went low enough to examine the corporation as an 'actor.' As stated earlier, the purpose was to understand how the social relations on which corporate activity occurs have changed over time. Here, though, we run into that nasty sociological issue of cause and effect. Since corporations are institutions populated with living people that actually do things (because a corporation cannot act by itself) any study of globalization would be incomplete without taking into account a wide variety of 'causes,' including the ideational level through which people come to understand their own reality. The historian Marc Bloch (1961/1993) captures this notion when he writes:

The framework of institutions which governs a society can in the last resort be understood only through a knowledge of the whole human environment. For though the artificial conception of man's activities which prompts us to carve up 
the creature of flesh and blood into the phantoms of homo oeconomicus, philosophicus, juridicus is doubtless necessary, it is tolerable only if we refuse to be deceived by it ... When it is a question of comparing two particular phenomena belonging to a separate series - a certain distribution of population, for example, with certain forms of legal groups - the delicate problem of cause and effect undoubtedly arises. On the other hand, to contrast two sets of dissimilar phenomena over a period of several centuries, and then say: 'Here on this side are all the causes; there on that are all the effects,' would be to construct the most pointless of dichotomies. A society, like a mind, is woven of perpetual interaction. For other researches, differently oriented, the analysis of the economy or the mental climate are culminating points; for the historian of the social structure they are a starting-point (p. 59).

What this means is that this dissertation is, in many ways, an ongoing project. To adequately account for the change in social structure that globalization represents, we would also have to provide an analysis of the changing mental climates of these different periods of time. Why, for instance, could an assistant manager of the Royal Bank of Canada proclaim in 1944 that he disagrees with the "theory that the rehabilitation of the world can be left to the haggling of the market" (McDowall, 1993, p. 302), while two decades later, the same tier of managers could express the view that "it is better to extend freedom than to proliferate controls" (Royal Bank of Canada, 1966, p. 15)? Is this not a total reversal of opinion? In order to limit the scope of the dissertation, I have therefore focused on the basic 'cause' found in capital's inherent need to self-expand; that is, the endless 
drive to accumulate more capital and thus, the inborn tendency toward centralization and concentration. This basic reduction allowed me to demonstrate that as capital grows over time, it eventually runs up against the very property relations (or rights) that were once central to its earlier development. In my view, this basic reality of the capitalist mode of production 'causes' many of the 'effects' that characterize our current epoch (even though the process itself is not so linear, and relies on a significant amount of contingency). That said, one area of future study might be a comparative-historical sociology of the relationship between the transformation of property relations that sustain capitalism and the changing views of Canada's corporate sector towards the workings of capitalism itself. Such a study could provide an important analysis of the changing mental climate in which such changes have occurred and are no doubt part of the results.

\subsection{Future Research}

As I noted in the last chapter, there are a few areas that are ripe for future research on the changing property relations of global capitalism. The first area is how capital is able to escape national regulations today. While I pointed to dark pools and temporary foreign worker programs as indicative of a more general trend, there needs to be more research into these means of escape so that we can better understand the implications; especially insofar as many of these means of escape are located deep within national domains even as they support a global organizing dynamic.

A second area of research is the continuous attempt by capital to create a global system of civil rights for transnational corporations by way of free trade agreements. The 
analysis of these agreements is important for anyone concerned about rising corporate power. Further analysis needs to be done on exactly how these agreements are able to limit the actions of nation-states, and the implications of those limits for the world's subordinate classes. Future research could also examine how these agreements differ from one another (i.e., is the difference significant?) and why national governments all over the world continue to sign them, even as they surrender important aspects of sovereignty. These agreements also raise important questions about how the future of the global political economy is to be organized. As it stands, these agreements only apply to a limited amount of the world's countries. One might therefore ask whether these agreements will end up pushing the global political economy toward a more unitary structure, or whether the future will consist of multiple, partial, and sometimes overlapping, normative orders that apply to different actors in different ways. Although our present period differs starkly from the medieval epoch, there is good reason that Sassen (2006) writes that, "in an abstract sense, the multifaceted political geography of the feudal order resembles today's emerging overlapping jurisdictions of national states, supranational institutions, and novel private global regimes" (p. 27).

I believe that the most significant area for future research, however, lies in the significant change in property relations that the blockchain represents. While it is clear that this emerging technology poses significant legal, social, and political challenges to existing institutions, especially traditional law and regulation authorities, there has been very little research as to how this technology is being developed and used. As it stands, there are limited engagements with the blockchain in respect to the political economy of 
Bitcoin (Karlstrøm, 2014; Kostakis \& Giotitsas, 2014) and business scholars are only just beginning to explore the various ways in which the blockchain might transform commercial activity (Tapscott \& Tapscott, 2016). Legal scholars have been the most active, exploring what types of law the blockchain should fall under and which governmental bodies should regulate it (De Filippi, 2014; De Filippi \& Mauro, 2014; Wright \& De Filippi, 2015). Outside of my own research (Garrod, 2016), however, there has been almost no empirical research as to how global financial institutions are planning to use the blockchain and the implications of this use. While the IMF suggests that the blockchain "could portend important structural shifts in the financial industry" (He et al., 2016, p. 23) there is currently no research on how these shifts might impact existing markets, nor what sort of new markets might be created as a result of this technology. What will happen when smart contracts are combined with high-frequency trading? If the blockchain can enable self-driving cars to own themselves, what will happen when autonomous selftrading financial firms have the capacity to own entire sectors of the global economy?

Since the blockchain is essentially a new means of enforcing property relations via code, future research should focus on how the blockchain is being used to automate the governance of property, and the wider social implications of this development. Research could focus, for instance, on the way in which the blockchain might change the way in which ownership rights are enforced (e.g., by governments or by code) and where they are 'located' in space (e.g., at the national or transnational level). Research might also focus on whether the blockchain constitutes the emergence of a digital state. Above all, researchers should pay attention to the ways in which this technology might alter the 
distribution of social power. Since the future is not determined, it is important for researchers to interject early in order to explore whether the blockchain could be leveraged for more socially beneficial uses than simply as a means to transport complex financial products for the world's largest banks. As I noted in the last chapter, there are a variety of ways in which the blockchain could be used to challenge the supremacy of private property. Will anything come from these developments? We will have to wait and see. What is clear, however, is that the blockchain represents a significant transformation of property relations; as such, it will need to be monitored closely.

\subsection{Practical Implications}

Before concluding, I would like to take a moment to discuss the practical implications of this dissertation. At the outset, I began with a simply question: why is it so hard to reform or challenge capitalism today? Over the course of this dissertation, I have attempted to demonstrate that the reason why is because the rights of capital are being moved to the transnational level, a process that works to limit the extent to which the nation-state can be used to legislate against corporate interests. I argued that this process should ultimately be taken as the basis of an emerging transnational state. That claim is one that is often accompanied by a sense of despair since it removes the nation-state as a site of struggle (e.g., Aronowitz, 2004; Barrow, 2005; Panitch \& Gindin, 2012). "By depicting capitalism as a globally unified system that cannot possibly be reformed," writes Fred Block (2001), theorists of the transnational state "make challenging capitalist rule seem impossibly difficult" (p. 217). This ends up "disempowering the very people who 
are supposed to challenge capitalist rule" (p. 217). While this might be true in the sense that, yes, such a thesis is rather depressing, I would rather make sure that those struggling against global capitalism (wherever they are) know exactly what it is that they are up against. In making clearer some of the qualitative changes that have accompanied globalization, my goal has been to demonstrate that there are fewer mechanisms by which noncorporate interests are able to mitigate the economic, social, and ecological crises generated by the preeminence of corporate rights.

The attempt has thus been to redirect class struggle away from the nation-state and back toward the more important issue of property itself. As the philosopher Slavoj Žižek (2012) notes, for Marx, the question of freedom was never located in the political sphere proper:

the key to actual freedom rather resides in the 'apolitical' network of social relations, from the market to the family, where the change needed if we want an actual improvement is not a political reform, but a change in the 'apolitical' social relations of production. We do not vote about who owns what, about relations in a factory, etc. - all this is left to processes outside the sphere of the political. It is illusory to expect that one can effectively change things by 'extending' democracy into this sphere, say, by organizing 'democratic' banks under people's control. In such 'democratic' procedures (which, of course, can have a positive role to play), no matter how radical our anti-capitalism is, the solution is sought in applying the democratic mechanisms - which, one should 
never forget, are part of the state apparatuses of the 'bourgeois' state that

guarantees undisturbed functioning of the capitalist reproduction (para. 15).

As such, we need to get away from the idea that our desire for democracy can only be fulfilled by the nation-state; in other words, that by somehow taking over the nation-state, or nationalizing certain industries that we can achieve a post-capitalist order. While the nation-state was certainly able to provide a high standard of living in many countries, it's ability to do so rested on a number of historical preconditions that are no longer with us.

Consequently, for us, the multitudinous many, it means that our struggle against capitalism must also go beyond the nation-state and focus more clearly on the widespread protection of common properties. This is, no doubt, a utopian proposal. There are no local, regional, or global institutions, as of yet, that are able to do this, and there are incredibly powerful interests that stand in the way. In the face of an increasingly dire future, however, it seems to necessary to acknowledge that the basic realities of our shared existence know no boundaries; as such, neither should our struggles. This means coming into confrontation with a capitalist class that not only views the entire world as a site of accumulation, but is actively attempting to transform it into one. This is the challenge for present and future generations, no matter where they reside. My hope is that this dissertation has provided some of those people with a better knowledge of what is happening, so that they might be able to come up with new institutions to bring us into a more positive future. 


\subsection{Conclusion}

In this dissertation, I have attempted to provide an alternative interpretation of globalization as a period of time beginning in the mid-1970s in which the rights of capital and the authority over those rights started to be moved to the transnational level. My purpose was to provide greater nuance to the longstanding debate over whether Canada is a dependency or an imperialist power. Rather than engaging in this debate head on, however, I wanted to demonstrate that the global political economy is changing in ways that confound the conceptual framework on which these existing interpretations rely-and with important consequences.

At a greater level, however, my purpose was also to draw our attention back to property. As the great Canadian political economist C.B. Macpherson (1978) pointed out many years ago, capitalism tends to reify property as private property, making it difficult to speak about the concept and the different ways in which property relations can be configured. The significance of noting these different configurations is at once historical, and at once practical. Historical, because changes to property are reflected in all sorts of different institutional configurations that reach down to the level of the person (and indeed, far beyond). Practical, because different configurations of property have very different outcomes for the ways in which real people are able to live their lives and reproduce themselves socially. Understanding that property relations can be configured in different ways is therefore a significant part of changing and shaping our contemporary circumstances. We can use property to evaluate whether or not our current social order is just and, if it isn't, explore how we might better reconfigure these relations to make them 
more equitable. We can also use property to judge whether particular social actors have too much power and whether or not they should. Assessing the outcome of any system of property relations is therefore to make a judgement call on one of the most fundamental aspects of living together as social beings. It means having the ability to see where we are going, and to ask whether this is a direction we want to go.

Philip Abrams (1972) once wrote that the point of historical sociology was not "to focus investigation on the social organization of historical processes but to set up a frame of reference for research on a thing called the social structure of the present" (p. 31). In this dissertation, with the aid of Marx, Sassen, and numerous others, I have attempted to create such a frame of reference by examining the transformation of the Royal Bank of Canada over 150 years. The goal of this research was to provide a closer look at globalization so that we might glimpse the extent to which liberal democracy is fading away before our very eyes (for an unfortunate, albeit humorous, view, see Figure 4). In my coming research, I will attempt to extend this view further into the future by attempting to grasp how blockchain technology might transform our existing political, economic, and social institutions; in other words, the ways in which our modern societies are organized. In attempting to look ahead at some of the prospects of what may come, I am reminded of the famous quote by Oscar Wilde (1891/1981) that "a dreamer is one who can only find his way by moonlight, and his punishment is that he sees the dawn before the rest of the world" (p. 136). For the present time, however, my thoughts go to Gilbert's far less quoted response to Earnest when asked, "his punishment?": 
And his reward. But see, it is dawn already. Draw back the curtains and open the windows wide. How cool the morning air is! Piccadilly lies at our feet like a long riband of silver. A faint purple mist hangs over the Park, and the shadows of the white houses are purple. It is too late to sleep. Let us go down to Covent Garden and look at the roses. Come! I am tired of thought (pp. 136-137). 


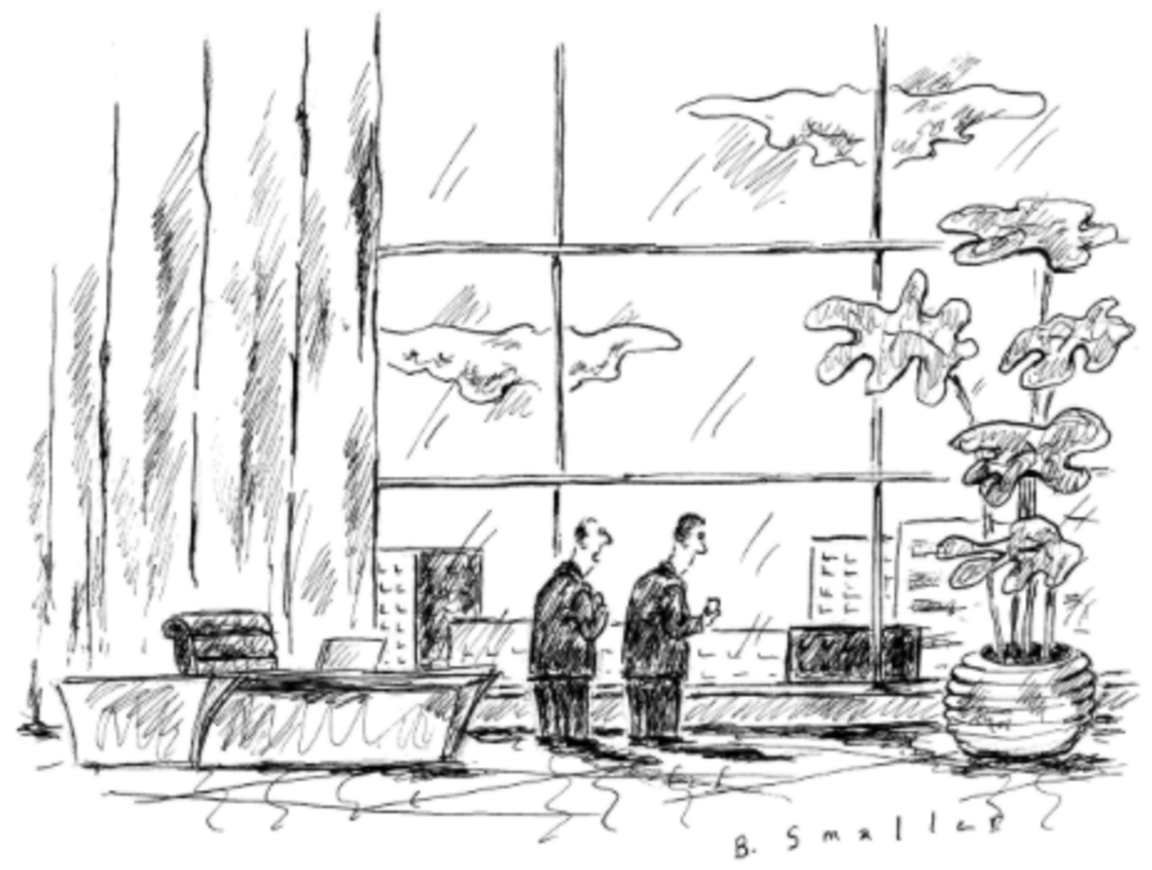

"Part of me is going to miss liberal democracy."

Figure 6. Part of me is going to miss liberal democracy. Reprinted from the New York Times, 2017, retrieved from http://www.newyorker.com/cartoons/a20660. Copyright 2017 by Barbara Smaller. Reprinted with permission. 


\section{Bibliography}

\section{Sources}

Newspapers:

The Globe and Mail from 1844

Financial Times from 1888

New York Times from 1851

\section{Government Reports:}

Report of the Royal Commission on Banking and Finance 1933

Report of the Royal Commission on Banking and Finance 1965

Report of the Royal Commission on Corporate Concentration 1978

$\underline{\text { Royal Bank of Canada: }}$

Royal Bank of Canada Annual Reports (1966-2014)

Royal Bank of Canada: Fiftieth Anniversary, 1869-1919 (1920)

Royal Bank of Canada Monthly Letters (1943-2008)

Royal Bank of Canada Newsletter and Interim Report 1976

\section{Works Cited}

Abrams, P. (1982). Historical sociology. Somerset, England: Open Books.

Ackerman, S. (2012, December). The red and the black. Jacobin. Retrieved from https:// www.jacobinmag.com/2012/12/the-red-and-the-black/ 
Albo, G., \& Klassen, J. (Eds.). (2013). Empire's ally: Canada and the war in Afghanistan. Toronto: University of Toronto Press.

Alden, E. (1999a, February 26). Canada change of strategy: Frustrated banks aim for cost cuts. Financial Times.

Alden, E. (1999b, October 4). RBC on lookout for American pie: Canada's largest bank thinks it would be a hit in the US. Financial Times.

Amelio, W. J. (2007, August 17). Worldsource or perish. Forbes. Retrieved February 8 , 2016, from http://www.forbes.com/2007/08/16/lenovo-world-sourcing-opedcx_wja_0817lenovo.html

Amin, S. (1974). Accumulation on a world scale: A critique of the theory of underdevelopment. New York: Monthly Review Press.

Anievas, A. (2008). Theories of a global state: A critique. Historical Materialism, 16(2), 190-206.

Armstrong, C., \& Nelles, H. V. (1988). Southern exposure: Canadian promoters in Latin America and the Caribbean, 1896-1930. Toronto: University of Toronto Press.

Armstrong, F. (1967). Approaches to business history in Canada: The historian's approach. In Proceedings of the Fourteenth Annual Meeting of the Business History Conference (pp. 16-33). University of Western Ontario, London, Ontario.

Aronowitz, S., \& Bratsis, P. (2002). Paradigm lost: State theory reconsidered. Minneapolis: University of Minnesota Press.

Arrighi, G. (2005). Hegemony Unravelling-1. New Left Review, (32), 23-80. 
Arrighi, G. (2010). The long twentieth century: Money, power, and the origins of our times. London : New York, NY: Verso. (Original work published 1994)

Arrighi, G., \& Silver, B. (Eds.). (1999). Chaos and governance in the modern world system. Minneapolis: University of Minnesota Press.

Balakrishnan, G. (2015). The Abolitionist-II. New Left Review, (91), 69-100.

Ban, C., Seabrooke, L., \& Freitas, S. (2016). Grey matter in shadow banking: International organizations and expert strategies in global financial governance. Review of International Political Economy, 1-33.

Banaji, J. (2007). Islam, the Mediterranean and the rise of capitalism. Historical Materialism, 15(1), 47-74.

Baragar, F., \& Seccareccia, M. (2008). Financial restructuring: Implications of recent Canadian macroeconomic developments. Studies in Political Economy, 82.

Baran, P. A. (1962). The political economy of growth. New York: Penguin Books. (Original work published 1957)

Baran, P. A., \& Sweezy, P. M. (1966). Monopoly capital: An essay on the American economic and social order. NYU Press.

Barrow, C. W. (2005). The return of the state: Globalization, state theory, and the new imperialism. New Political Science, 27(2), 123-145.

Baum, D. J. (1974). The banks of Canada in the Commonwealth Caribbean: Economic nationalism and multinational enterprises of a medium power. New York: Praeger. 
Bauwens, M., \& Kostakis, V. (2016). Peer-to-peer: Anew opportunity for the left. ROAR Magazine. Retrieved from https://roarmag.org/essays/peer-to-peer-bauwenskostakis/

Beaulieu, E., \& Cherniwchan, J. (2014). Tariff structure, trade expansion, and Canadian protectionism, 1870-1910. Canadian Journal of Economics/Revue Canadienne D’économique, 47(1), 144-172.

Beck, U. (2000). The cosmopolitan perspective: Sociology of the second age of modernity. The British Journal of Sociology, 51(1), 79-105.

Bederman, D. J. (1988). Bank for International Settlements and the debt crisis: A new role for the central bankers' bank. Int'l Tax \& Bus. Law., 6(1), 92-121.

Beltrame, J., \& Blanchfield, M. (2013, November 1). EU boasts of huge gains in Canadian trade deal. Retrieved December 2, 2015, from http://www.cbc.ca/news/ business/eu-boasts-of-huge-gains-in-canadian-trade-deal-1.2325983

Bennett, R. A. (1979, September 12). Canadian bank's U.S. role grows. New York Times.

Berle, A. A., \& Means, G. C. (1968). The modern corporation and private property. New York: Harcourt, Brace \& World.

Better Late. (1964, June 12). The Globe and Mail.

Bichler, S., \& Nitzan, J. (2012). Imperialism and financialism: A story of a nexus. Journal of Critical Globalization Studies, (5), 42-78.

Bienefeld, M. (1992). Financial deregulation: Disarming the nation state. Studies in Political Economy, 37, 31-58. 
Binhammer, H. H. (1972). Money, banking and the Canadian financial system. Toronto: Methuen Publications. (Original work published 1968)

Blackstone, W. (1893). Commentaries on the laws of England in four books, vol. 1. Philadelphia: J.B. Lippincott Company. (Original work published 1753)

Bliss, M. (2006). Has Canada failed? Literary Review of Canada, 14(2), 3-5.

Bloch, M. (1993). Feudal society, volume 1: The growth of ties of dependence. London: Routledge. (Original work published 1961)

Block, F. (2001). Using social theory to leap over historical contingencies: A comment on Robinson. Theory and Society, 30(2), 215-221.

Block, F., \& Somers, M. R. (2014). The power of market fundamentalism. Cambridge, Mass: Harvard University Press.

Blomley, N. (2011). Cuts, flows, and the geographies of property. Law, Culture and the Humanities, 7(2), 203-216.

Blomley, N. (2015). The territory of property. Progress in Human Geography, 1-17.

Bollier, D. (2015, April 4). The blockchain: A promising new infrastructure for online commons. Retrieved from http://bollier.org/blog/blockchain-promising-newinfrastructure-online-commons

Bonner, R. W. (1970, December 10). Capital has no nationality: The Empire Club addresses. Retrieved January 4, 2015, from http://speeches.empireclub.org/60681/ data 
Boreham, G. F. (1989). The changing landscape of the financial services industry in Canada: Some implications for managers. Service Industries Journal, 9(2), 191204.

Boroujerdi, R. D., \& Wolf, C. (2015). Themes, Dreams and Flying Machines (Emerging Theme Radar). New York: Goldman Sachs.

Bowley, G. (1999, November 22). Canadian banks reveal strong profits. Financial Times.

Boyer, R., \& Drache, D. (1996). States against markets: The limits of globalization. London: Routledge.

Branch, J. (2016). Territory as an institution: Spatial ideas, practices and technologies. Territory, Politics, Governance, 5(2), 131-144.

Braudel, F. (1992a). Civilization and capitalism, 15th-18th century, Volume I: The structures of everyday life (S. Reynolds, Trans.). Berkeley: University of California Press. (Original work published in 1979)

Braudel, F. (1992b). Civilization and capitalism, 15th-18th century, Volume II: The wheels of commerce (S. Reynolds, Trans.). Berkeley: University of California Press. (Original work published in 1979)

Braudel, F. (1992c). Civilization and capitalism, 15th-18th century, Volume III: The perspective of the world (S. Reynolds, Trans.). Berkeley: University of California Press. (Original work published in 1979)

Braudel, F. (1995). The Mediterranean and the Mediterranean world in the age of Philip II, Volume I (S. Reynolds, Trans.). Berkeley: University of California Press. (Original work published in 1949) 
Breckenridge, R. M. (1894). The Canadian banking system, 1817-1890. New York: American Economic Association.

Brennan, J. (2013). The power underpinnings, and some distributional consequences, of trade and investment liberalization in Canada. New Political Economy, 18(5), $715-747$.

Brennan, J. (2015). Ascent of giants: NAFTA, corporate power and the growing income gap. Ottawa: Canadian Centre for Policy Alternatives.

Brenner, N., Peck, J., \& Theodore, N. (2010). Variegated neoliberalization: Geographies, modalities, pathways. Global Networks, 10(2), 182-222.

Brenner, R. (1977). The origins of capitalist development: a critique of neo-Smithian Marxism. New Left Review, 104(1), 25-92.

Brenner, R. (2003). Merchants and revolution: Commercial change, political conflict, and London's overseas traders, 1550-1653. New York: Verso.

Brewer, T. (2002). Marxist theories of imperialism: A critical survey. London: Routledge. (Original work published 1980)

Brodie, M. J. (1990). The political economy of Canadian regionalism. Toronto: Harcourt Brace Jovanovich.

Bromley, S. (2003). Reflections on empire, imperialism and United States hegemony. Historical Materialism, 11(3), 17-68.

Brownlee, J. (2005). Ruling Canada: Corporate cohesion and democracy. Black Point, NS: Fernwood Pub. 
Brummer, C. (2014). Minilateralism: How trade alliances, soft law and financial engineering are redefining economic statecraft. New York: Cambridge University Press.

Bryan, D., Rafferty, M., \& Wigan, D. (2016). Politics, time and space in the era of shadow banking. Review of International Political Economy, 1-26.

Buckley, K. (1974). Capital formation in Canada, 1896-1930. Kingston; Montreal: McGill-Queen's University Press.

Bukharin, N. (1929). Imperialism and world economy. New York: Monthly Review Press. (Original work published 1917)

Burbach, R., \& Robinson, W. (1999). The fin de siecle debate: Globalization as epochal shift. Science \& Society, 63(1).

Burgess, B. (2000). Foreign direct investment: Facts and perceptions about Canada. Canadian Geographer, 44(2), 98-113.

Burgess, W. (2002). Canada's location in the world system: Reworking the debate in Canadian political economy (unpublished doctoral dissertation). The University of British Columbia, Vancouver, Canada.

Buterin, V. (2015, February 24). Triple canopy: Decentralized autonomous society by Vitalik Buterin with Sam Frank. Retrieved May 7, 2015, from http:// www.canopycanopycanopy.com/contents/decentralized-autonomous-societytranscript 
Cain, P. J., \& Hopkins, A. G. (1986). Gentlemanly capitalism and British expansion overseas I. The old colonial system, 1688-1850. The Economic History Review, 39(4), 501-525.

Cain, P. J., \& Hopkins, A. G. (1993). British imperialism: Innovation and expansion, 1688-1914. London: Longman.

Callinicos, A. (2009). Imperialism and global political economy. Cambridge: Polity.

Cameron, D. (1983). Order and disorder in the world economy: International finance in evolution. Studies in Political Economy, 11, 105-126.

Cameron, R. E., Bovykin, V. I., \& Anan'ich, B. V. (Eds.). (1991). International banking, 1870-1914. New York: Oxford University Press.

Cammack, P. (2003). The governance of global capitalism: A new materialist perspective. Historical Materialism, 11(2), 37-59.

Cammack, P. (2009). Forget the transnational state. Geopolitics, History, and International Relations, (2), 79-97.

Canada (1933). The report of the Royal Commission on Banking and Finance 1933. Ottawa.

Canada. (1964). The report of the Royal Commission on Banking and Finance. Ottawa. Canada. (1978). The report of the Royal Commission on Corporate Concentration. Ottawa.

Canada picks head for central bank. (1934, September 6). New York Times. Canadian bank buys 15-story home here. (1919, February 1). New York Times. 
Canadian banks don't need too-big-to-fail reserves. (2012, August 28). The Globe and Mail. Retrieved from http://www.theglobeandmail.com/globe-debate/editorials/ canadian-banks-dont-need-too-big-to-fail-reserves/article4507085/

Canadian banks hold two spots among top 20. (1966, July 26). The Globe and Mail. Canadian explains bank credit curb. (1959, August 18). New York Times.

Canadian law limits foreign bank growth. (1980, December 2). New York Times.

Canadian Press. (2014, November 21). Royal Bank exits Caribbean wealth management business. $C B C$. Retrieved from http://www.cbc.ca/1.2844864

Cardoso, F. H., \& Faletto, E. (1979). Dependency and development in Latin America. Berkeley: University of California Press.

Carr, J., Mathewson, F., \& Quigley, N. (1995). Stability in the absence of deposit insurance: The Canadian banking system, 1890-1966. Journal of Money, Credit and Banking, 27(4), 1137.

Carroll, W. (1982). The Canadian corporate elite: Financiers or finance capitalists. Studies in Political Economy, 8, 89-114.

Carroll, W. (1985). Dependency, imperialism and the Capitalist class in Canada. In R. J. Brym (Ed.), The structure of the Canadian capitalist class. Toronto: Garamond Press.

Carroll, W. (1986). Corporate power and Canadian capitalism. Vancouver: University of British Columbia Press.

Carroll, W. (2012). Global, transnational, regional, national: The need for nuance in theorizing global capitalism. Critical Sociology, 38(3), 365-371. 
Carroll, W. (2013). Global capitalism, American empire, collective imperialism? Studies in Political Economy, 92.

Carroll, W., \& Daub, S. (2016, October 6). Why is the CEO of a big Canadian bank giving speeches about... Retrieved from http://www.corporatemapping.ca/rbc-ceospeech-climate-pipelines/

Carroll, W., \& Klassen, J. (2011). Transnational class formation? Globalization and the Canadian corporate network. Journal of World-Systems Research, 17(2).

Carruthers, B. G. (1996). City of capital: Politics and markets in the English financial revolution. Princeton: Princeton University Press.

Carruthers, B. G., \& Ariovich, L. (2004). The sociology of property rights. Annual Review of Sociology, 30(1), 23-46.

Carruthers, B. G., \& Kim, J.C. (2011). The sociology of finance. Annual Review of Sociology, 37(1), 239-259.

Castells, M. (2000). Materials for an exploratory theory of the network society. British Journal of Sociology, 51(1), 5-24.

Centre for Policy Studies. (2006). Big bang 20 years on: New challenges facing the financial services sector. London.

Chandler, A. D. (1977). Visible hand: The managerial revolution in American business. Cambridge, Mass: Harvard University Press.

Chant, J. (1979). The banks and the concentration of corporate power. In P. K. Gorecki \& W. T. Stanbury (Eds.), Perspectives on the Royal Commission on Corporate Concentration. Montreal: Institute for Research on Public Policy. 
Chen, C., Koustas, A., \& Goertzen, A. (2015). The Trans-Pacific Partnership: A landmark trade deal for Canada. Canada: Bank of Montreal.

Chen, L. (2015). 2015 global 2000: The world's largest banks. Forbes. Retrieved December 9, 2016, from http://www.forbes.com/sites/liyanchen/2015/05/06/2015global-2000-the-worlds-largest-banks/

Chodos, R. (1977). The Caribbean connection. Toronto: James Lorimer \& Company, Publishers.

Christophers, B. (2013). Banking across boundaries: Placing finance in capitalism. Malden, MA: John Wiley \& Sons.

Clarkson, S. (2001). The multi-level state: Canada in the semi-periphery of both continentalism and globalization. Review of International Political Economy, $8(3)$.

Clarkson, S. (2004). Global governance and the semi-peripheral State: The WTO and NAFTA as Canada's external constitution. In S. Clarkson \& M. Cohen (Eds.), Governing under stress: Middle powers and the challenge of globalization. London: Zed Books.

Clarkson, S. (2008). Does North America exist?: Governing the continent after NAFTA and 9/11. Toronto: University of Toronto Press.

Clarkson, S., \& Wood, S. (2010). A perilous imbalance: The globalization of Canadian law and governance. Vancouver: University of British Columbia Press.

Clement, W. (1975). The Canadian corporate elite: An analysis of economic power. Toronto: McClelland and Stewart. 
Clement, W. (1977). Continental corporate power: Economic elite linkages between Canada and the United States. Toronto: McClelland and Stewart.

Clement, W. (1978). Canada and multinational corporations: An overview. In D. Glenday, H. Guindon, \& A. Turowetz (Eds.), Modernization and the Canadian state. Toronto: The Macmillan Company of Canada Limited.

Clement, W. (1979). An exercise in legitimation: Ownership and control in the report of the Royal Commission on Corporate Concentration. In P. K. Gorecki \& W. T. Stanbury (Eds.), Perspectives on the Royal Commission on Corporate Concentration. Montreal: Institute for Research on Public Policy.

Clement, W. (1992). Continentalization and regime change: Labour, capital and the state in Sweden and Canada. In The entry into new economic communities: Swedish and Canadian perspectives on the European Economic Community and North America Free Trade Accord. Toronto: Swedish-Canadian Academic Foundation.

Clement, W. (2006). Corporate power in a globalizing world: A study in elite social organization. Canadian Journal of Sociology/Cahiers Canadiens de Sociologie, $31(1), 146-148$

Cohen, T. (2013, April 30). Temporary foreign worker reforms a political solution that will hurt the economy, business community says. Retrieved from http:// o.canada.com/news/national/temporary-foreign-worker-reforms-a-politicalsolution-that-will-hurt-the-economy-business-community-says 
Coleman, W., \& Porter, T. (2003). “Playin' along”: Canada and global finance. In W. Clement \& L. F. Vosko (Eds.), Changing Canada: Political economy as transformation (pp. 241-264). Kingston; Montreal: McGill-Queen's University Press.

Coleman, W., \& Sajed, A. (2013). Fifty key thinkers on globalization. London: Routledge. Corcoran, T. (2015, June 22). Terence Corcoran: Dark pools vs protectionism. Financial Post. Retrieved from http://business.financialpost.com/fp-comment/terencecorcoran-dark-pools-vs-protectionism

Corrigan, P. R. D., Ramsay, H., \& Sayer, D. (1980). The state as a relation of production. In P. R. D. Corrigan (Ed.), Capitalism, state formation and marxist theory: Historical investigations. London: Quartet Books.

Cox, R. (1981). Social forces, states and world orders: Beyond international relations theory. Millennium - Journal of International Studies, 10(2), 126-155.

Cox, R. (1987). Production, power, and world order: Social forces in the making of history. New York: Columbia University Press.

Creighton, J. H. (1933). Central banking in Canada. Vancouver: Clarke \& Stuart.

Crow, J. W., \& Fischer, S. (2002). Making money: An insider's perspective on finance, politics, and Canada's central bank. Etobicoke, ON: Wiley.

Cuba funds saved by Canadian bank. (1960, December 10). New York Times.

Curtiss, C. A. (1939). Banking. In W. S. Wallace (Ed.), The encyclopedia of Canada (Vol. 1, pp. 151-164). Toronto: University Associates of Canada. 
Cutler, A. C. (2011). The privatization of authority in the global political economy. In S. McBride \& G. Teeple (Eds.), Relations of global power: Neoliberal order and disorder. Toronto: University of Toronto Press.

Daft, D., \& Fitzgerald, N. (2004). Business can help bridge the transatlantic rift. Financial Times.

Daniel, F. (2002). Recent changes to Canada's financial sector legislation. Bank of Canada Review. Retrieved from http://core.kmi.open.ac.uk/download/pdf/ 6504098.pdf

Darroch, J. L. (1992). Global competitiveness and public policy: The case of Canadian multinational banks. Business History, 34(3), 153.

Darroch, J. L. (1994). Canadian banks and global competitiveness. Kingston; Montreal: McGill-Queen's University Press.

Davis, L. E., \& Gallman, R. E. (2001). Evolving financial markets and international capital flows: Britain, the Americas, and Australia, 1865-1914. New York: Cambridge University Press.

De Filippi, P. (2014). Bitcoin: A regulatory nightmare to a libertarian dream. Internet Policy Review, 3(2). Retrieved from http://policyreview.info/articles/analysis/ bitcoin-regulatory-nightmare-libertarian-dream

De Filippi, P. (2014). Ethereum: Freenet or Skynet?. Guerrilla Translation. Retrieved from http://www.guerrillatranslation.org/2014/11/20/ethereum-freenet-or-skynet/ 
De Filippi, P. (2015, March 8). How the blockchain may support and facilitate community governance. Retrieved from https://www.digitalcurrencycouncil.com/ professional/how-the-blockchain-may-support-and-facilitate-communitygovernance/

De Filippi, P., \& Hassan, S. (2016). Blockchain technology as a regulatory technology: From code is law to law is code. First Monday, 21(12). Retrieved from http:// firstmonday.org/ojs/index.php/fm/article/view/7113/5657

De Filippi, P., \& Mauro, R. (2014). Ethereum: The decentralised platform that might displace today's institutions. Internet Policy Review. Retrieved from https:// policyreview.info/articles/news/ethereum-decentralised-platform-might-displacetodays-institutions $/ 318$

DeLanda, M. (2006). A new philosophy of society: Assemblage theory and social complexity. New York: A\&C Black.

Demirović, A. (2011). Materialist state theory and the transnationalization of the capitalist state. Antipode, 43(1), 38-59.

Deneault, A. (2011). Offshore: Tax havens and the rule of global crime. (G. Holoch, Trans.). New York: New Press.

Deneault, A. (2013). Financial secrecy index: Narrative report on Canada. Tax Justice Network.

Deneault, A. (2015). Canada a new tax haven: How the country that shaped Caribbean offshore jurisdictions is becoming one itself. Vancouver: Talonbooks. 
Deneault, A., \& Sacher, W. (2012). Imperial Canada Inc.: Legal haven of choice for the world's mining industries. (R. Philpot \& F. A. Reed, Trans.). Vancouver: Talonbooks.

Denison, M. (1967). Canada's first bank: A history of the Bank of Montreal. Toronto: McClelland \& Stewart.

Desai, R. (2013). Geopolitical economy: After US hegemony, globalization and empire. London: Pluto Press.

Dilley, A. (2012). Finance, politics, and imperialism: Australia, Canada, and the City of London, 1896-1914. London: Palgrave Macmillan UK.

Dodd, N. (2014). The social life of money. Princeton: Princeton University Press.

Dolack, P. (2017, February 10). TPP is not dead: It's now called the Trade In Services Agreement. Retrieved February 12, 2017, from http://www.counterpunch.org/ 2017/02/10/tpp-is-not-dead-its-now-called-the-trade-in-services-agreement/

Dominican Republic Is Lent \$185 Million. (1979, March 20). New York Times.

Dominion Bureau of Statistics. (1927). Canada Year Book 1927-28. Ottawa.

Dominion Bureau of Statistics. (1930). Canada Year Book 1930. Ottawa.

Dominion Bureau of Statistics. (1950). Canada Year Book 1950. Ottawa.

Dominion Bureau of Statistics. (1967). Canada Year Book 1967. Ottawa.

Dow, A., \& Dow, S. (2014). Economic history and economic theory: The staples approach to economic development. Cambridge Journal of Economics, 38(6), 1339-1353. 
Drache, D. (1977). Staple-ization: A theory of Canadian capitalist development. In C. Heron (Ed.), Imperialism, nationalism, and Canada: Essays from the Marxist Institute of Toronto. Toronto: New Hogtown Press.

Draimin, T., \& Swift, J. (1975). What's Canada doing in Brazil? This Magazine.

Drainville, A. C. (1995). Monetarism in Canada and the world economy. Studies in Political Economy, 46, 7-42.

Draper, H. (1977). Karl Marx's theory of revolution, vol. 1: State and bureaucracy. New York: Monthly Review Press.

Drummond, I. (1987). Corporate power and Canadian capitalism by William K. Carroll (review). The Canadian Historical Review, 68(4), 638-639.

Dwyer Jr., G. P. (1996). Wildcat banking, banking panics, and free banking in the United States. Economic Review-Federal Reserve Bank of Atlanta, 81(3-6), 1.

Eckardt, H. M. P. (1914). Manual of Canadian banking. Montreal: Monetary Times. Ehrensaft, P., \& Armstrong, W. (1981). The formation of dominion capitalism: Economic truncation and class structure. In A. Moscovitch \& G. Drover (Eds.), Inequality: Essays on the political economy of social welfare. Toronto: University of Toronto Press.

Eichengreen, B. J. (2008). Globalizing capital: A history of the international monetary system. Princeton: Princeton University Press. (Original work published 1996) Emmanuel, A. (1972). Unequal exchange: A study of the imperialism of trade. New York: Monthly Review Press. 
Erman, B. (2013, June 25). New exchange to take on TSX. The Globe and Mail. Retrieved from http://www.theglobeandmail.com/report-on-business/newexchange-to-take-on-tsx/article12790216/

Fichtner, J. (2016). The anatomy of the Cayman Islands offshore financial center: AngloAmerica, Japan, and the role of hedge funds. Review of International Political Economy, 1-30.

Fligstein, N. (2002). The architecture of markets: An economic sociology of twenty-firstcentury capitalist societies. Princeton: Princeton University Press.

Foreman, L. (2014, October 4). The crazy medieval island of Sark. Retrieved October 10, 2014, from http://www.thedailybeast.com/articles/2014/10/04/the-crazymedieval-island-of-sark.html

Foster, J. B. (2003). Imperialism now. New York: Monthly Review Press.

FP 500: 2008. (2008). Financial Post. Retrieved from http://www.financialpost.com/ news/fp500/2008/index.html

Frank, A. G. (1966). The development of underdevelopment. Monthly Review, 18.

Frank, A. G. (1967). Capitalism and underdevelopment in Latin America. New York: New York University Press.

Frank, S. (2015, January). Come with us if you want to live. Harper's Magazine. Retrieved from http://harpers.org/archive/2015/01/come-with-us-if-you-want-tolive/

Franklin, U. M. (1999). The real world of technology (CBC Massey Lectures series). Toronto: House of Anansi Press. (Original work published 1990) 
Freedman, C. (1998). The Canadian banking system. Ottawa: Bank of Canada.

Freeland, C. (2012). Plutocrats: The rise of the new global super-rich and the fall of everyone else. Toronto: Doubleday Canada.

Fuchs, C. (2010). Critical globalization studies: An empirical and theoretical analysis of the new imperialism. Science \& Society, 74(2), 215-247.

Fullerton, D. H. (1986). Graham Towers and his times: A biography. Toronto: McClelland \& Stewart.

Furtado, C. (1961). Desenvolvimento e subdesenvolvimento. Brazil: Editôra Fundo de Cultura.

Furtado, C. (1967). Teoria e política do desenvolvimento econômico. Brazil: Companhia Editora Nacional.

Galbraith, J. A. (1970). Canadian banking. Toronto: Ryerson Press.

Garrod, J. Z. (2015). A critique of Panitch and Gindin's theory of American empire. Science \& Society, 79(1), 38-62.

Garrod, J. Z. (2016). The real world of the Decentralized Autonomous Society. tripleC: Communication, Capitalism \& Critique. Open Access Journal for a Global Sustainable Information Society, 14(1), 62-77.

Germain, R. (1997). The international organization of credit: States and global finance in the world-economy. New York: Cambridge University Press.

Germain, R. (2010). Global politics and financial governance. New York: Palgrave Macmillan.

Giddens, A. (1990). The consequences of modernity. Stanford: Stanford University Press. 
Gilbert, E. (2003). Forging a national currency: Money, state-making and nation-building in Canada. In E. Gilbert \& E. Helleiner (Eds.), Nation-States and money: The past, present and future of national currencies. New York: Routledge.

Gill, S. (1991). American hegemony and the Trilateral Commission. New York: Cambridge University Press.

Gill, S. (1993). Gramsci, historical materialism and international relations. New York: Cambridge University Press.

Gilman, N. (2014). The twin insurgency. American Interest, 15.

Gindin, S., \& Panitch, L. (2012). The making of global capitalism: The political economy of American empire. New York: Verso.

Global ranking of Canadian banks, 1970-2000. (1970-2000). The Banker.

Glossary of technical terms. (2009). Historical Materialism, 17(2), 109-113.

Glyn, A., \& Sutcliffe, B. (1992). Global but leaderless? The new capitalist order. Socialist Register, 28(28).

Gnodde, R. (2007, November 12). New actors play a vital role in the global economy. Financial Times. Retrieved from http://www.ft.com/cms/s/0/d9c2af2a-90c0-11dca6f2-0000779fd2ac.html\#axzz3yMUNP8pq

Goldstein, J. (2013, October 13). Trading Places. The New York Times.

Gordon, D. (1988). The global economy: New edifice or crumbling foundations? New Left Review, (168), 24-64.

Gordon, T. (2010). Imperialist Canada. Winnipeg: Arbeiter Ring Pub. 
Gorecki, P. K., Stanbury, W. T. (1979). Perspectives on the Royal Commission on Corporate Concentration. Montreal: Institute for Research on Public Policy.

Gould, E. (2010). Nobody's poster child. Canadian Centre for Policy Alternatives. Retrieved from http://www.policyalternatives.ca/sites/default/files/uploads/ publications/reports/docs/Nobodys_Poster_Child.pdf

Government of Canada. (2016). North American Free Trade Agreement (NAFTA).

Retrieved January 6, 2017, from http://www.international.gc.ca/trade-agreementsaccords-commerciaux/agr-acc/nafta-alena/info.aspx?lang=eng

Government of Canada. (1933). Report of the Royal Commission on Banking and Currency in Canada. Retrieved from http://publications.gc.ca/site/ eng/472925/publication.html

Gowan, P. (1999). The global gamble: Washington's Faustian bid for world dominance. New York: Verso.

Graeber, D. (2011). Debt: The first 5000 years. Brooklyn: Melville House Publishing.

Gray, J. N. (1977). On the contestability of social and political concepts. Political Theory, $5(3), 331-348$.

Grossman, R. S. (2010). Unsettled account: The evolution of banking in the industrialized world since 1800. Princeton: Princeton University Press.

Guyana to restructure its Eurocurrency debt. (1980, February 6). American Banker.

Hager, S. B. (2015). Corporate ownership of the public debt: Mapping the new aristocracy of finance. Socio-Economic Review, 13(3), 505-523. 
Hall, C. (2015, September 12). "Liberals in a hurry”? That's Trudeau, not Mulcair's NDP. Retrieved September 14, 2015, from http://www.cbc.ca/news/politics/canadaelection-2015-chris-hall-liberals-ndp-1.3225365

Hall, W. (1982, February 9). Orion's bid for stardom. Financial Times.

Handa, J. (2002). Monetary economics. London: Routledge.

Hann, C. M. (1998). Property relations: Renewing the anthropological tradition. New York: Cambridge University Press.

Hardt, M., \& Negri, A. (2000). Empire. Cambridge, MA.: Harvard University Press.

Hardt, M., \& Negri, A. (2005). Multitude: War and democracy in the age of empire. New York: Penguin.

Hardt, M., \& Negri, A. (2009). Commonwealth. Cambridge, MA.: Harvard University Press.

Harris, J. (2005). To be or not to be: The nation-centric world order under globalization. Science \& Society, 69(3), 329-340.

Harris, J. (2009). Statist globalization in China, Russia and the Gulf States. Science \& Society, 73(1), 6-33.

Harris, J. (2010). The world economic crisis and transnational corporations. Science \& Society, 74(3), 394-409.

Harris, J. (2014). Transnational capitalism and class Formation. Science \& Society, 78(3), 312-333.

Harris, L. (1991). Finance capital. In T. Bottomore (Ed.), A Dictionary of Marxist Thought. London: Wiley. 
Harris, S. (2010). The global financial meltdown and financial regulation: Shirking and learning - Canada in an international context. In G. B. Doern \& C. Stoney (Eds.), How Ottawa spends, 2010-2011: Recession, realignment, and the new deficit era. Kingston; Montreal: McGill-Queen's Press.

Harvey, D. (2000). Spaces of hope. Berkeley: University of California Press.

Harvey, D. (2003a). The new imperialism. New York: Oxford University Press.

Harvey, D. (2003b). The 'new' imperialism: Accumulation by dispossession. In L.

Panitch \& C. Leys (Eds.), The new imperial challenge: Socialist register 2004. London: Merlin Press.

Harvey, D. (2004). The "new" imperialism: Dispossesion by accumulation. Socialist Register, 40.

Harvey, D. (2005). A brief history of neoliberalism. New York: Oxford University Press.

Harvey, D. (2009). The art of rent: Globalization, monopoly and the commodification of culture. Socialist Register, 38(38).

Havana bank is bombed. (1931, September 2). New York Times.

Hayes, S. L., \& Hubbard, P. M. (1990). Investment banking: A tale of three cities. Cambridge, MA: Harvard Business School Press.

He, D., Habermeier, K., Leckow, R., Haksar, V., Almeida, Y., Kashima, M., KyriakosSaad, N., Oura, H., Sedik, T. S., Stetsenko, N. (2016). Virtual currencies and beyond: Initial considerations. New York: International Monetary Fund.

Heilbroner, R. (1986). The nature and logic of capitalism. New York: W.W. Norton \& Company. 
Held, D., McGrew, A., Goldblatt, D., \& Perraton, J. (1999). Global transformations:

Politics, economics and culture. Stanford: Stanford University Press.

Helleiner, E. (1994). States and the reemergence of global finance: From Bretton Woods to the 1990s. Ithaca: Cornell University Press.

Helleiner, E. (1995). Great transformations: A Polanyian perspective on the contemporary global financial order. Studies in Political Economy, 48.

Helleiner, E. (1997). Braudelian reflections on economic globalization: The historian as pioneer. In S. Gill \& J. H. Mittelman (Eds.), Innovation and transformation in international relations theory. New York: Cambridge University Press.

Helleiner, E. (2003). The making of national money: Territorial currencies in historical perspective. Ithaca: Cornell University Press.

Helleiner, E. (2013). Did the financial crisis generate a fourth pillar of global economic architecture? Swiss Political Science Review, 19(4), 558-563.

Heller, H. (2012). Imperialist Canada, Todd Gordon, Winnipeg: Arbeiter Ring Publishing, 2011. Historical Materialism, 20(2), 222-231.

Henwood, D. (1998). Wall Street. New York: Verso.

Heron, J. (1969). The first hundred years : The Royal Bank of Canada, 1869-1969. Montreal: Royal Bank of Canada.

Higgins, S. (2015, January 17). IBM reveals proof of concept for Blockchain-powered Internet of Things. Retrieved from http://www.coindesk.com/ibm-reveals-proofconcept-blockchain-powered-internet-things/ 
Hilferding, R. (1981). Finance capital: A study in the latest phase of capitalist

development. (T. Bottomore, Ed., M. Watnick \& S. Gordon, Trans.). London:

Routledge \& Kegan Paul. (Original work published 1910)

Hirst, P., \& Thompson, G. (2015). Globalization in question. Hoboken: John Wiley \& Sons. (Original work published in 1996)

Hobsbawm, E. (1989). Age of empire: 1875-1914. New York: Vintage.

Hobson, J. A. (2005). Imperialism: A study. New York: Cosimo Classics. (Original work published 1902)

Hudson, G. (1959, June 25). Bank chief says time is nearing to loosen tight money situation. The Globe and Mail.

Hudson, P. J. (2010). Imperial designs: The Royal Bank of Canada in the Caribbean. Race \& Class, 52(1), 33-48.

Hurtig, M. (2003). The vanishing country: Is it too late to save Canada?. Toronto: McClelland \& Stewart.

Hymer, S. (1979). The multinational corporation: A radical approach. New York: Cambridge University Press.

Iacobucci, E., Trebilcock, M. J., \& Winter, R. A. (2006). The Canadian experience with deregulation. University of Toronto Law Journal, 56(1), 1-74.

Ikeda, S. (2004). Zonal structure and the trajectories of Canada, Mexico, Australia, and Norway under neo-liberal globalization. In S. Clarkson \& M. G. Cohen (Eds.), Governing under Stress: Middle Powers and the challenge of globalization. London: Zed Books. 
Ince, C. H. (1970). The Royal Bank of Canada: A chronology, 1864-1969. Montreal: Royal Bank of Canada.

Ingham, G. (1999). Capitalism, money and banking: A critique of recent historical sociology. The British Journal of Sociology, 50(1), 76-96.

Innis, H. A. (1978). The cod fisheries: The history of an international economy. Toronto: University of Toronto Press. (Original work published 1940)

Innis, H. A. (1999). The fur trade in Canada: An introduction to Canadian economic history. Toronto: University of Toronto Press. (Original work published 1927) Jackson, A. (2007). From leaps of faith to hard landings: Fifteen years of "free trade." In R. Grinspun \& Y. Shamsie (Eds.), Whose Canada?: Continental integration, fortress North America, and the corporate agenda. Kingston; Montreal: McGillQueen's University Press.

Jamieson, A. B. (1953). Chartered banking in Canada. Toronto: Ryerson Press.

Jeffees, W. (1952, January 11). Finance at large. The Globe and Mail.

Jenkins, P. (1996). An acre of time. Toronto: Macfarlane Walter \& Ross.

Jenson, J. (1989). "Different" but not "exceptional": Canada's permeable fordism. Canadian Review of Sociology/Revue Canadienne de Sociologie, 26(1), 69-94.

Jenson, J. (1991). All the world's a stage: Ideas, spaces and times in Canadian political economy. Studies in Political Economy, 36.

Jessop, B. (2015, July 19). UK politics and global capitalism. Jacobin. Retrieved October 17, 2016, from https://www.jacobinmag.com/2015/07/cameron-miliband-blairukip/ 
Jones, G. G. (2006). The rise of corporate nationality. Harvard Business Review, 84(10), $20-22$.

Kalecki, M. (1971). Selected essays on the dynamics of the capitalist economy 19331970. New York: Cambridge University Press.

Kapstein, E. B. (1994). Governing the global economy: International finance and the state. Cambridge, MA: Harvard University Press.

Kapur, A., Macleod, N., \& Singh, N. (2005). Plutonomy: Buying luxury, explaining global imbalances. New York: Citigroup Global Markets.

Karlstrøm, H. (2014). Do libertarians dream of electric coins? The material embeddedness of Bitcoin. Distinktion: Scandinavian Journal of Social Theory, 15(1), 23-36.

Kaufman, M. (1985). The internationalization of Canadian bank capital (with a look at bank activity in the Caribbean and Central America). Journal of Canadian Studies, 19(4), 61-81.

Kautsky, K. (1970). Ultra-imperialism. New Left Review, (59), 41-46. (Original work published 1914)

Kay, C. (1989). Latin American theories of development and underdevelopment. New York: Routledge.

Keister, L. A. (2002). Financial markets, money, and banking. Annual Review of Sociology, 28(1), 39-61.

Kellogg, P. (2005). Kari Levitt and the long detour of Canadian political economy. Studies in Political Economy, 76. 
Kellogg, P. (2009). Of nails and needles: A reconsideration of the political economy of Canadian trade. Socialist Studies/Études Socialistes, 4(2), 67-92.

Kellogg, P. (2015). Escape from the staple trap: Canadian political economy after left nationalism. Toronto: University of Toronto Press.

Kelly, J. (2015, September 29). RBC, TD join top banks in using bitcoin technology. The Globe and Mail. Retrieved from http://www.theglobeandmail.com/report-onbusiness/rbc-td-among-top-banks-joining-r3-fintech-consortium/article26590959/

Keynes, J. M. (2016). General theory of employment, interest and money. New Delhi, India: Atlantic Publishers \& Distributors. (Original work published 1936)

Kiladze, T. (2014, December 29). Too big to disrupt? Canada's banks fight back against the likes of Apple, Facebook. The Globe and Mail. Retrieved from http:// www.theglobeandmail.com/report-on-business/feature-too-big-to-disrupt/ article22163574/

Kiladze, T., \& Marotte, B. (2016, April 6). RBC faces tough questions over Panama connections. The Globe and Mail. Retrieved from http:// www.theglobeandmail.com/report-on-business/financial-services-firms-shouldbe-force-for-good-rbc-chief-says/article29537700/

Klassen, J. (2008). Hollowing out? Myth and reality. Relay, 22.

Klassen, J. (2009). Canada and the new imperialism: The economics of a secondary power. Studies in Political Economy, 83, 163-190.

Klassen, J. (2014). Joining empire: The political economy of the new Canadian foreign policy. Toronto: University of Toronto Press. 
Konings, M. (2011). The development of American finance. New York: Cambridge University Press.

Kostakis, V., \& Giotitsas, C. (2014). The (a) political economy of Bitcoin. tripleC: Communication, Capitalism \& Critique. Open Access Journal for a Global Sustainable Information Society, 12(2), 431-440.

Krugman, P. (2012). End this depression now!. New York: W. W. Norton.

Kuczynski, P.-P. (1988). Latin American debt. Baltimore: Johns Hopkins University Press.

Lacher, H. (2006). Beyond globalization: Capitalism, territoriality and the international relations of modernity. London: Routledge.

Lam, E., \& Alexander, D. (2014, April 10). "RBC Nice" pays off amid high-frequencytrading outcry. Bloomberg.com. Retrieved from http://www.bloomberg.com/ news/articles/2014-04-10/-rbc-nice-pays-off-amid-high-frequency-trading-outcry

Langille, D. (1987). The Business Council on National Issues and the Canadian state. Studies in Political Economy, 24, 41-85.

Lapavitsas, C. (2013). Profiting without producing: How finance exploits us all. New York: Verso.

Laxer, J. (1983). Oil and gas: Ottawa, the provinces and the petroleum industry. Toronto: James Lorimer Limited, Publishers.

Lazzarato, M. (2012). The making of the indebted man. Los Angeles: Semiotexte.

Lebel, R. (1968, January 12). Annual meeting: Royal Bank chief says pacts with US undermining Canada's independence. The Globe and Mail. 
Lenin, V. I. (1999). Imperialism: The highest stage of capitalism. Sydney: Resistance Books. (Original work published 1917)

Levitt, K. (1970). Silent surrender. New York: St. Martins Press.

Lew1s, M. (2014). Flash boys: A Wall Street revolt. New York: Simon and Schuster.

Liodakis, G. (2005). The new stage of capitalist development and the prospects of globalization. Science \& Society, 341-366.

Liodakis, G. (2010). Totalitarian capitalism and beyond. Burlington, VT: Ashgate.

Liodakis, G. (2012). Crisis, the emerging new stage of capitalism, and the need of a transnational class strategy for social emancipation. International Critical Thought, 2(1), 7-22.

Lipset, S. M. (1990). Continental divide: The values and institutions of the United States and Canada. London: Routledge.

Little, D. (2016, November 30). DeLanda on historical ontology. Retrieved from http:// understandingsociety.blogspot.com/2016/11/delanda-on-historical-ontology.html

Lower, A. R. M. (1945). Colony to nation: A history of Canada. Toronto: Longmans, Green.

Lower, A. R. M. (1958). Theories of Canadian federalism-yesterday and today. In A.R.M. Lower (Ed.), Evolving Canadian Federalism. Durham, NC: Duke University Press.

Lumsden, I. (Ed.). (1970). Close the 49th parallel etc: The Americanization of Canada. Toronto: University of Toronto Press. 
Luxemburg, R. (2003). The accumulation of capital. London: Routledge. (Original work published 1913)

Lysandrou, P., \& Nesvetailova, A. (2014). The role of shadow banking entities in the financial crisis: A disaggregated view. Review of International Political Economy, $1-23$.

Macdonald, D. (2012). The big banks' big secret: Estimating government support for Canadian banks during the financial crisis. Ottawa: Canadian Centre for Policy Alternatives.

Macdonald, L. (1997). Going global: The politics of Canada's foreign economic relations. In W. Clement (Ed.), Understanding Canada: Building on the new Canadian political economy. Montreal; Kingston: McGill-Queen’s University Press.

MacDonald, L. R. (1975). Merchants against industry: An idea and its origins. The Canadian Historical Review, 56(3), 263-281.

Macpherson, C. B. (1962). The political theory of possessive individualism: Hobbes to Locke. Oxford: Clarendon Press.

Macpherson, C. B. (1978). Property, mainstream and critical positions. Toronto: University of Toronto Press.

Macpherson, C. B. (2013). Democracy in Alberta: Social Credit and the party system. Toronto: University of Toronto Press. (Original work published 1953) Magdoff, H. (1969). The age of imperialism: The economics of U.S. foreign policy. New York: New York University Press. 
Malcolm, A. H. (1980, June 18). Royal Bank outgrows Canada. New York Times.

Marazzi, C. (2010). The violence of financial capitalism. (K. Lebedeva, Trans.). Los Angeles: Semiotexte.

Marchak, P. (1985). Canadian political economy. Canadian Review of Sociology/Revue Canadienne de Sociologie, 22(5), 673-709.

Marchildon, G. P., \& McDowall, D. (1992). Canadian multinationals and international finance. London: Routledge.

Martin, J. (2012). Case study: The Toronto-Dominion Bank and Canada's "Little Bang" of 1987. Rotman School of Management. Retrieved from https:// www.rotman.utoronto.ca/-/media/Files/Programs-and-Areas/ CanadianBusinessHistory/TD\%20Bank\%20and\%20the\%20Little\%20Bang\%20of \%201987_REVISED.pdf

Martin, P. (1998). The Competition Bureau's letter to the Royal Bank and Bank of Montreal. Retrieved June 9, 2015, from http:/www.competitionbureau.gc.ca/eic/ site/cb-bc.nsf/eng/01612.html

Marx, K. (1844). Critical notes on the article: "The King of Prussia and social reform. By a Prussian.” Vorwarts! Berlin.

Marx, K. (1955). The poverty of philosophy. Moscow: Progress Publishers. (Original work published 1847).

Marx, K. (1969). Theories of surplus value. London: Lawrence \& Wishart.

Marx, K. (1978a). Preface to the first German edition. In R. C. Tucker (Ed.), The MarxEngels reader. New York: Norton. (Original work published 1867) 
Marx, K. (1978b). A contribution to the critique of political economy. In R. C. Tucker (Ed.), The Marx-Engels reader. New York: Norton. (Original work published 1859)

Marx, K. (1978c). The economic and philosophical manuscripts of 1844. In R. C. Tucker (Ed.), The Marx-Engels reader. New York: Norton. (Original work published 1844)

Marx, K. (1986). The civil war in France. In J. Elster (Ed.), Karl Marx: A reader. New York: Cambridge University Press. (Original work published 1871)

Marx, K. (1991a). Capital: Volume 3: A critique of political economy. New York: Penguin Classics. (Original work published 1894)

Marx, K. (1991b). Capital: Volume 1: A critique of political economy. New York: Penguin Classics. (Original work published 1867)

Marx, K., \& Engels, F. (1978a). Manifesto of the Communist Party. In R. C. Tucker (Ed.), The Marx-Engels reader. New York: Norton. (Original work published 1848)

Marx, K., \& Engels, F. (1978b). The German ideology. In R. C. Tucker (Ed.), The MarxEngels reader. New York: Norton. (Original work published 1932)

Mason, J. (2013). The illusion of Canadian banks? Retrieved from http:// www.safehaven.com/article/29977/the-illusion-of-canadian-banks

McBride, S. (2005). Paradigm shift: Globalization and the Canadian state. Halifax: Fernwood Publishing Co., Ltd. 
McBride, S. (2011). The new constitutionalism: International and private rule in the new global order. In S. McBride \& G. Teeple (Eds.), Relations of global power: Neoliberal order and disorder. Toronto: University of Toronto Press.

McDowall, D. (1993). Quick to the frontier: Canada's Royal Bank. Toronto: McClelland \& Stewart.

McGregor, R. (2007, October 5). Life and soul for the party. Financial Times. Retrieved from http://www.ft.com/cms/s/0/1a3850ac-7166-11dc-98fc-0000779fd2ac.html \#axzz3zaXFTpEB

McIvor, R. C. (1958). Canadian monetary, banking, and fiscal development. Toronto: Macmillan.

McKay, D. (2015). Address to shareholders. Retrieved from http://www.rbc.com/ newsroom/speeches/20150410-dm-annual-mtg.html

McNally, D. (1981). Staple theory as commodity fetishism: Marx, Innis and Canadian political economy. Studies in Political Economy, 6.

McQuaig, L. (2007). Holding the bully's coat: Canada and the U.S. Empire. Toronto: Doubleday Canada.

Mertins-Kirkwood, H. (2014). Unmasking the Trans-Pacific Partnership: A critical Canadian political-economic analysis (unpublished master's dissertation). Carleton University, Ottawa.

Mills, C. W. (1962). The Marxists. New York: Dell Pub. Co. 
Monbiot, G. (2013, November 4). This transatlantic trade deal is a full-frontal assault on democracy. The Guardian. Retrieved from http://www.theguardian.com/ commentisfree/2013/nov/04/us-trade-deal-full-frontal-assault-on-democracy

Monks, R. A. G., \& Minow, N. (2011). Corporate governance. Chichester: John Wiley \& Sons.

Moore, S., \& Wells, D. (1975). Imperialism and the national question in Canada. Toronto.

Morck, R. K., Percy, M., Tian, G. Y., \& Yeung, B. (2007). A history of corporate governance around the world: Family business groups to professional managers. Chicago: University of Chicago Press.

Morrison, S. (1998a, July 21). RBC to buy Credit Suisse division. Financial Times. Morrison, S. (1998b, July 8). RBC and Koch in strategic alliance. Financial Times. Mozley, H. N. (1977). Mozley and Whiteley's law dictionary. London: Butterworths. Myers, G. (1972). A history of Canadian wealth. Toronto: Lorimer. (Original work published 1914)

National Post Staff. (2011, March 21). WTF: The federal budget and 50 years of Canadian debt. National Post. Retrieved from http://nationalpost.com/news/cana da/canadian-politics/graphic-50-years-of-canadian-debt/

Naylor, R. T. (1972). The rise and fall of the third commercial empire of the St Lawrence. In G. Teeple (Ed.), Capitalism and the national question in Canada. Toronto: University of Toronto Press. 
Naylor, R. T. (1982). Monetarism and Canadian policy alternatives. Ottawa: Canadian Centre for Policy Alternatives.

Naylor, R. T. (1985). Dominion of debt: Centre, periphery and the international economic order. Vancouver: Black Rose Books.

Naylor, R. T. (1994). Hot money and the politics of debt. Vancouver: Black Rose Books. (Original work published 1987)

Naylor, R. T. (1997). The history of Canadian business, 1867-1914. Vancouver: Black Rose Books. (Original work published 1975)

Nerbas, D. (2013). Dominion of capital: The politics of big business and the crisis of the Canadian bourgeoisie, 1914-1947. Toronto: University of Toronto Press.

Neufeld, E. P. (1958). Bank of Canada operations and policy. Toronto: University of Toronto Press.

Neufeld, E. P. (1972). The financial system of Canada, its growth and development. New York: St. Martin's Press.

Newman, P. C. (1979). The Canadian establishment. Toronto: McClelland \& Stewart. Newman, P. C. (1999). Titans: How the new Canadian establishment seized power. New York: Penguin.

Niosi, J. (1985). Canadian multinationals. Toronto: Between the Lines.

Nitzan, J., \& Bichler, S. (2006). New imperialism or new capitalism? Review, XXIX(1), $1-86$.

Norfield, T. (2012). Derivatives and capitalist markets: The speculative heart of capital. Historical Materialism, 20(1), 103-132. 
Norfield, T. (2016). The City: London and the global power of finance. New York: Verso.

Norrie, K. H., \& Owram, D. (1991). A history of the Canadian economy. Toronto: Harcourt Brace.

Ontario Securities Commission. (2010). Dark liquidity in the Canadian market. Toronto.

Palmisano, S. J. (2006). The globally integrated enterprise. Foreign Affairs, 127-136.

Panitch, L. (1981). Dependency and class in Canadian political economy. Studies in Political Economy, 6.

Panitch, L. (1994). Globalization and the state. Socialist Register, 30(30).

Panitch, L., \& Gindin, S. (2004). Global capitalism and American empire. London: Merlin Press.

Panitch, L., \& Gindin, S. (2005). Superintending global capital. New Left Review, 35, $101-123$.

Park, L. C., \& Park, F. W. (1962). Anatomy of big business. Toronto: Progress Books.

Paterson, D. G. (1976). British direct investment in Canada, 1890-1914. Toronto: University of Toronto Press.

Patterson, E. L. S. (1932). Canadian banking. Toronto: Ryerson Press.

Pentland, H. C. (1981). Labour and capital in Canada 1650-1860. Toronto: James Lorimer \& Company.

Pfeffer, A. (2013, April 10). Rise in foreign temp workers questioned by labour groups. $C B C$. Retrieved November 18, 2016, from http://www.cbc.ca/news/politics/risein-foreign-temp-workers-questioned-by-labour-groups-1.1361027 
Piketty, T. (2014). Capital in the twenty-first century. (A. Goldhammer, Trans.).

Cambridge, Mass: Harvard University Press.

Pittis, D. (2015, December 3). Canada's banking bet on the world's 1\%. CBC. Retrieved from http://www.cbc.ca/news/business/rbc-results-city-nationalhollywood-1.3347853

Plumptre, A. F. W. (1977). Three decades of decision: Canada and the world monetary system, 1944-75. Toronto: McClelland and Stewart.

Polanyi, K. (2002). The great transformation: The political and economic origins of our time. Boston: Beacon Press. (Original work published 1944)

Pollard, S. (1974). European economic integration, 1815-1970. London: Thames \& Hudson.

Porter, J. (1965). The vertical mosaic: An analysis of social class and power in Canada. Toronto: University of Toronto Press.

Porter, T. (2005). Globalization and finance. Malden, MA: Polity Press.

Prebisch, R. (1950). The economic development of Latin America and its principal problems. United Nations: Economic Commission for Latin America. Retrieved from http://archivo.cepal.org/pdfs/cdPrebisch/002.pdf

Prudham, S., \& Coleman, W. D. (2011). Introduction: Property, autonomy, territory, and globalization. In W. D. Coleman (Ed.), Property, territory, globalization struggles over autonomy. Vancouver: University of British Columbia Press.

Qualicum Institute. (2014). Canada's federal debt. Qualicum Institute. Retrieved from http://qualicuminstitute.ca/federal-debt/ 
Quigley, N. (1986). The chartered banks and foreign direct investment in Canada. Studies in Political Economy, 19.

Quigley, N. C. (1989). The bank of Nova Scotia in the Caribbean, 1889-1940. Business History Review, 63(4), 797-838.

Raney, T. (2009). As Canadian as possible... Under what circumstances?: Public opinion on national identity in Canada outside Quebec. Journal of Canadian Studies/ Revue D'études Canadiennes, 43(3), 5-29.

Rao, G. C. (2010). The national question in Canadian development: Permeable nationalism and the ideological basis for incorporation into empire. Studies in Political Economy, 85.

RBC among nine subpoenaed in Libor probe. (2012). Retrieved January 2, 2014, from http://www.theglobeandmail.com/globe-investor/rbc-among-nine-subpoenaed-inlibor-probe/article4678432/

Resnick, P. (1982). The maturing of Canadian capitalism. Our Generation, 15(3), 11-24.

Resnick, P. (2005). The European roots of Canadian identity. Toronto: University of Toronto Press.

Richardson, R. J. (1982). "Merchants against industry": An empirical study of the Canadian debate. Canadian Journal of Sociology / Cahiers Canadiens de Sociologie, 7(3), 279.

Rizzo, P. (2016, February 25). Royal Bank of Canada reveals Blockchain trial with Ripple. Retrieved from http://www.coindesk.com/royal-bank-canada-revealsblockchain-remittance-trial-ripple/ 
Robertson, G., Grant, T., Stueck, W., Tait, C., Cryderman, K., \& Curry, B. (2013, April 12). The long list of Canadian firms that have sought temporary foreign workers. The Globe and Mail. Retrieved from http://www.theglobeandmail.com/report-onbusiness/economy/jobs/the-long-list-of-canadian-firms-that-have-soughttemporary-foreign-workers/article11113782/

Robertson, G., \& Kiladze, T. (2012). U.S. regulator accuses Royal Bank of "wash trade” scheme. The Globe and Mail. Retrieved January 2, 2014, from http:// www.theglobeandmail.com/globe-investor/us-regulator-accuses-royal-bank-ofwash-trade-scheme/article4097931/

Robertson, R. (1992). Globalization: social theory and global culture. London: SAGE Publications.

Robinson, W. I. (2001). Global capitalism and nation-state-centric thinking: What we don't see when we do see nation-states: Response to critics. Science \& Society, 65(4), 500-508.

Robinson, W. (2003). The debate on globalization. Science \& Society, 67(3).

Robinson, W. (2004). A theory of global capitalism: Transnational production, transnational capitalists, and the transnational state. Baltimore: Johns Hopkins University Press.

Robinson, W. (2005). Global capitalism: The new transnationalism and the folly of conventional thinking. Science \& Society, 69(3).

Robinson, W. (2007). Beyond the theory of imperialism: Global capitalism and the transnational state. Societies Without Borders, 2(1), 5-26. 
Robinson, W. (2008). Latin America and global capitalism: A critical globalization perspective. Baltimore: Johns Hopkins University Press.

Robinson, W. (2009). Saskia Sassen and the sociology of globalization: A critical appraisal. Sociological Analysis, 3(1), 5-29.

Robinson, W. (2011). Globalization and the sociology of Immanuel Wallerstein: A critical appraisal. International Sociology, 26(6), 723-745.

Robinson, W. (2012). Global capitalism theory and the emergence of transnational elites. Critical Sociology, 38(3), 349-363.

Robinson, W. (2014). Global capitalism and the crisis of humanity. New York: Cambridge University Press.

Robinson, W., \& Harris, J. (2000). Towards a global ruling class? Globalization and the transnational capitalist class. Science \& Society, 64(1).

Roy, W. G. (1997). Socializing capital: The rise of the large industrial corporation in America. Princeton: Princeton University Press.

Royal Bank of Canada. (1948, June). Canada's natural resources. The Royal Bank of Canada Monthly Letter, 29(6).

Royal Bank of Canada. (1966). Annual report. Montreal.

Royal Bank of Canada. (1976a). Newsletter and interim report: First quarter. Montreal.

Royal Bank of Canada. (1976b). Newsletter and interim report: Second quarter. Montreal.

Royal Bank of Canada. (1976c). Newsletter and interim report: Third quarter. Montreal. Royal Bank of Canada. (1992). Annual report. Montreal. 
Russia Sells Banker On Trade as Peace Key. (1956, June 27). The Globe and Mail.

Samman, A., Coombs, N., \& Cameron, A. (2015). For a post-disciplinary study of finance and society. Finance and Society, 1(1), 1-5.

Sassen, S. (2003). Globalization or denationalization? Review of International Political Economy, 10(1), 1-22.

Sassen, S. (2006). Territory, authority, rights: From medieval to global assemblages. Princeton: Princeton University Press.

Sassen, S. (2007). A sociology of globalization. New York: W. W. Norton \& Company.

Sassen, S. (2012). Global finance and its institutional spaces. In K. K. Cetina \& A. Preda (Eds.), The Oxford handbook of the sociology of finance. Oxford: Oxford University Press.

Sassen, S. (2013). When territory deborders territoriality. Territory, Politics, Governance, $1(1), 21-45$.

Sassen, S. (2014a). Finance as capability: Good, bad, dangerous. Occasion, 7.

Sassen, S. (2014b). Expulsions: Brutality and complexity in the global economy. Cambridge, MA: Belknap Press.

Schmidt, R. (1981). Canadian political economy: A critique. Studies in Political Economy, 6.

Scholte, J. A. (2004). Globalization: Prospects for a paradigm shift. In M. Shaw (Ed.), Politics and globalization: Knowledge, ethics and agency. New York: Taylor \& Francis. 
Schrauwers, A. (2008). Revolutions without a revolutionary moment: Joint stock democracy \& the transition to capitalism in Upper Canada. Canadian Historical Review, 89(2), 223-225.

Schrauwers, A. (2010). The gentlemanly order \& the politics of production in the transition to capitalism in Upper Canada. Labour/Le Travail, 65, 9-45.

Seccareccia, M. (2007). Critical macroeconomic aspects of economic integration. In R. Grinspun \& Y. Shamsie (Eds.), Whose Canada?: Continental integration, fortress North America, and the corporate agenda. Kingston; Montreal: McGill-Queen's University Press.

Sewell, Jr., W. H. (1996). Historical events as transformations of structures: Inventing revolution at the Bastille. Theory and Society, 25(6), 841-881.

Shecter, B. (2017, January 10). Canada's banks won't see big mortgage losses when interest rates rise, says RBC CEO Dave McKay. Financial Post. Retrieved from http://business.financialpost.com/news/fp-street/canadas-banks-wont-see-bigmortgage-losses-when-interest-rates-rise-says-rbc-ceo-dave-mckay

Siltanen, J. (2002). Paradise paved? Reflections on the fate of social citizenship in Canada. Citizenship Studies, 6(4), 395-414.

Sinclair, S. (2015). NAFTA Chapter 11 investor-state disputes to January 1, 2015. Canadian Centre for Policy Alternatives. Retrieved from https:// www.policyalternatives.ca/publications/reports/nafta-chapter-11-investor-statedisputes-january-1-2015 
Singer, H. W. (1950). The distribution of gains between investing and borrowing countries. The American Economic Review, 40(2), 473-485.

Sirota, D. (2015, June 23). Trade pact: How the Trans-Pacific Partnership gives corporations special legal rights. Retrieved June 23, 2015, from http:// www.ibtimes.com/trade-pact-how-trans-pacific-partnership-gives-corporationsspecial-legal-rights-1975817

Sklair, L. (1997). Social movements for global capitalism: The transnational capitalist class in action. Review of International Political Economy, 4(3), 514-538.

Sklair, L. (2001). The transnational capitalist class. Oxford: Blackwell.

Sklair, L. (2002). The transnational capitalist class and global politics: Deconstructing the corporate-state connection. International Political Science Review, 23(2), 159174.

Sklair, L., \& Robbins, P. T. (2002). Global capitalism and major corporations from the Third World. Third World Quarterly, 23(1), 81-100.

Skocpol, T. (1994). Wallerstein's world capitalist system: A theoretical and historical critique. In T. Skocpol (Ed.), Social revolutions in the modern world. New York: Cambridge University Press.

Smaller, B. (2017). Part of me is going to miss liberal democracy. The New Yorker.

Smardon, B. (2010). Rethinking Canadian economic development: The political economy of Canadian fordism, 1880-1914. Studies in Political Economy, 85.

Smardon, B. (2011). Shifting terrains of accumulation: Canadian industry in three eras of development. Studies in Political Economy, 87. 
Smith, J. (2016). Imperialism in the twenty-first century: Globalization, superexploitation, and capitalism's final crisis. New York: New York University Press.

Smith, M. (2016, March 29). From fine wine to lotteries: Blockchain tech takes off. $B B C$ News. Retrieved March 29, 2016, from http://www.bbc.com/news/ business-35890616

So, A. Y. (1990). Social change and development: Modernization, dependency, and world-systems theories. Newbury Park: Sage Publications.

Soederberg, S. (2000). Political restructuring of exploitation: An historical materialist account of the emergence of neoliberalism in Canada. Cultural Logic, 3(2).

Soederberg, S. (2004). The politics of the new international financial architecture: Reimposing neoliberal domination in the global south. New York: Zed Books.

Soederberg, S. (2010). Corporate power and ownership in contemporary capitalism: The politics of resistance and domination. New York: Routledge.

Stanford, J. (2008). Staples, deindustrialization, and foreign investment: Canada's economic journey back to the future. Studies in Political Economy, 82.

Stanford, J. (Ed.). (2014). The staple theory@ 50: Reflections on the lasting significance of Mel Watkins' "A staples theory of economic growth". Ottawa: Canadian Centre for Policy Alternatives.

Statistics Canada (2011, October 13). Foreign control in the Canadian economy. The Daily. Retrieved from http://www.statcan.gc.ca/daily-quotidien/111013/ dq111013b-eng.htm 
Statistics Canada (2013, March 28). Gross domestic product by industry, January 2013. The Daily. Statistics Canada Catalogue no. 11-001-X, 1-5. Retrieved from http:// www.statcan.gc.ca/daily-quotidien/130328/dq130328a-eng.pdf

Statistics Canada (2013, May 9). Foreign direct investment, 2012. The Daily. Statistics Canada Catalogue no. 11-001-X, 1-4. Retrieved from http://www.statcan.gc.ca/ daily-quotidien/130509/dq130509a-eng.pdf

Statistics Canada (2017, March 29). Federal net debt per capita since 1867. The Daily. Statistics Canada Catalogue no. 11-001-X, 1-3. Retrieved from http://www.stat can.gc.ca/daily-quotidien/170329/dq170329h-eng.pdf

Steindl, J. (1952). Maturity and stagnation in American capitalism. New York: New York University Press.

Stiglitz, J. (2008, December 5). Getting bang for your buck. The Guardian. Retrieved from https:/www.theguardian.com/commentisfree/cifamerica/2008/dec/05/useconomy-keynesian-economic-theory

Stiglitz, J. (2009, April 11). A global crisis requires global solutions. The Guardian. Retrieved from http://www.theguardian.com/commentisfree/2009/apr/09/globaleconomy-development

Strange, S. (1997). Casino capitalism. Manchester: Manchester University Press.

Strange, S. (2015). Mad money. Manchester: Manchester University Press.

Sutherland, G. (2014). Performance and potential: Toronto's financial services sector, 2014. Canada: The Conference Board of Canada. 
Swedberg, R. (2003). Principles of economic sociology. Princeton: Princeton University Press.

Sweeny, R. (1997). Banking as class action: Social and national struggles in the history of Canadian banking. In A. Teichova, G. K. Hentenryk, \& D. Ziegler (Eds.), Banking, trade and industry: Europe, America and Asia from the thirteenth to the twentieth Century. New York: Cambridge University Press.

Sweezy, P. M., \& Magdoff, H. (1972). Dynamics of U.S. Capitalism. New York: Monthly Review Press.

Tabb, W. (2009). Globalization today: At the borders of class and state theory. Perspectives on Global Development and Technology, 8(2), 121-138.

Tapscott, D., \& Tapscott, A. (2016). Blockchain revolution: How the technology behind Bitcoin is changing money, business, and the world. New York: Penguin.

Tasca, P., \& Ulieru, M. (2016). Blockchain as an institutional technology spearheading an equitable exchange economy. Retrieved from https://papers.ssrn.com/sol3/ papers.cfm?abstract_id $=2872916$

Taylor, F. W. (1911). Canada and Canadian banking. Journal of the Royal Society of the Arts, 59(3053), 714-727.

Teeple, G. (Ed.). (1972). Capitalism and the national question in Canada. Toronto: University of Toronto Press.

Teeple, G. (2000). Globalization and the decline of social reform: Into the twenty-first century. Aurora, ON: Garamond Press. 
Teeple, G. (2005). A Commentary on Joel Bakan's “The corporation, the pathological pursuit of profit and power". Socialist Studies/Études Socialistes, 1(2).

Teeple, G. (2007). Honoured in the breach: Human rights as principles of a past age. Studies in Social Justice, 1(2), 136-145.

Teeple, G. (2011). Notes on the continuing economic crisis. In S. McBride \& G. Teeple (Eds.), Relations of global power: Neoliberal order and disorder. Toronto: University of Toronto Press.

Teles, N. (2016, April 27). Socialize the banks. Jacobin. Retrieved from https:// www.jacobinmag.com/2016/04/banks-credit-recession-finance-socialism/

Teschke, B. (2003). The myth of 1648: Class, geopolitics, and the making of modern international relations. New York: Verso.

Teschke, B. (2006). Debating "The myth of 1648": State formation, the interstate system and the emergence of capitalism in Europe — a rejoinder. International Politics, $43(5), 531-573$.

Teschke, B., \& Lacher, H. (2007). The changing "logics” of capitalist competition. Cambridge Review of International Affairs, 20(4), 565-580.

The Royal Bank of Canada: Address made at the annual meeting of shareholders. (1953, January 9). The Globe and Mail.

The Royal Bank of Canada: Fiftieth Anniversary, 1869-1919. (1920). Montreal: The Ronalds Press and Advertising Agency Limited. 
Thelen, K. A. (2004). How institutions evolve: The political economy of skills in Germany, Britain, the United States, and Japan. New York: Cambridge University Press.

Therborn, G. (1984). Classes and states: Welfare state developments, 1881-1981. Studies in Political Economy, 14(1), 7-41.

Thomas, G., \& Morgan-Witts, M. (1979). The day the bubble burst: A social history of the Wall Street crash. London: Hamish Hamilton.

Tilly, C. (1984). Big structures, large processes, huge comparisons. New York: Russell Sage.

Tomba, M. (2013). Accumulation and time: Marx's historiography from the Grundrisse to Capital. Capital \& Class, 37(3), 355-372.

Tomlinson, J. (1999). Globalization and culture. Cambridge: Polity Press.

Tomlinson, K. (2013, April 6). RBC replaces Canadian staff with foreign workers. $C B C$. Retrieved November 18, 2016, from http://www.cbc.ca/news/canada/britishcolumbia/rbc-replaces-canadian-staff-with-foreign-workers-1.1315008

“Too big to fail" bank rules unveiled. (2014, November 10). BBC News. Retrieved from http://www.bbc.com/news/business-29982181

Trichur, R., \& Steinberg, J. (2015, January 22). Royal Bank of Canada to buy City National for \$5.4 Billion. Wall Street Journal. Retrieved from http:// www.wsj.com/articles/royal-bank-of-canada-to-buy-city-national-for-5-4billion-1421930814 
United Nations Conference on Trade and Development. (2007). The universe of the largest transnational corporations. New York: United Nations.

United Nations Conference on Trade and Development. (2012). World investment report 2012: Towards a new generation of investment policies. New York: United Nations.

United Nations Conference on Trade and Development. (2013). Recent developments in investor-state dispute settlement. New York: United Nations.

United Nations Conference on Trade and Development. (2014). World investment report 2014: Investing in the SDGs: An action plan. New York: United Nations.

Van Houten, G. (1991). Corporate Canada: An historical outline. Toronto: Progress Books.

Varoufakis, Y. (2011). The global minotaur: America, the true origins of the financial crisis and the future of the world economy. London: Zed Books Ltd.

Veblen, T. (2005). The theory of business enterprise. New York: Cosimo Classics. (Original work published 1904)

Veltmeyer, H. (1987). Canadian corporate power. Aurora, ON: Garamond Press.

Vigna, P., \& Casey, M. J. (2015). The age of cryptocurrency: How Bitcoin and digital money are challenging the global economic order. New York: St. Martin's Press.

Vitali, S., Glattfelder, J. B., \& Battiston, S. (2011). The network of global corporate control. PLoS ONE, 6(10).

Wachtel, H. M. (1990). The money mandarins: The making of a supranational economic order. New York: Routledge. 
Wallerstein, I. (1984). The politics of the world-economy: The states, the movements and the civilizations. New York: Cambridge University Press.

Wallerstein, I. (2000). Globalization or the age of transition? A long-term view of the trajectory of the world-system. International Sociology, 15(2), 249-265.

Wallerstein, I. (2004). World-systems Analysis: An Introduction. Durham, NC: Duke University Press.

Wallerstein, I. (2010). A world-system perspective on the social sciences. The British Journal of Sociology, 61, 167-176.

Wallerstein, I. (2011). The modern world-system: Capitalist agriculture and the origins of the European world-economy in the sixteenth century. Berkeley: University of California Press. (Original work published 1974)

Watkins, M. (1968). Foreign ownership and the structure of Canadian industry: Report of the Task Force on the Structure of Canadian Industry, January 1968. Ottawa: Privy Council Office.

Watkins, M. (1984). A staple theory of economic growth. In W.T. Easterbrook \& M. Watkins (Eds.), Approaches to Canadian economic history: A selection of essays. Kingston; Montreal: McGill-Queen's Press. (Original work published 1963) Watkins, M. (1989). The political economy of growth. In W. Clement \& G. Williams (Eds.), The new Canadian political economy. Kingston; Montreal: McGillQueen's Press.

Watkins, M. (2007). Staples redux. Studies in Political Economy, 79. 
Weber, M. (2014). The agrarian sociology of ancient civilizations. New York: Verso. (Original work published 1976)

Weeks, J. (1991). Imperialism. In T. Bottomore (Ed.), A dictionary of Marxist thought. London: Wiley.

Weiss, L. (1997). Globalization and the myth of the powerless state. New Left Review, (225), 3-27.

Whiteside, H. (2012). Crisis of capital and the logic of dispossesion and repossesion. Studies in Political Economy, 89, 59-78.

Whittington, L. (1999). The banks: The ongoing battle for control of Canada's richest business. Toronto: Stoddart.

Whittington, L. (2014, September 7). Canada-EU free-trade pact would give foreign banks wider scope to sue Canadian regulators. The Toronto Star. Retrieved from http://www.thestar.com/news/canada/2014/09/07/eu_trade_pact_could_weaken _ottawas_power_to_regulate_banks.html

Wild, J. (2017, January 26). Blockchain believers hold fast to a utopian vision. Financial Times. Retrieved January 26, 2017, from https://www.ft.com/content/a12d7476bc6a-11e6-8b45-b8b81dd5d080

Wilde, O. (1981). The critic as artist. In R. Aldington \& S. Weintraub (Eds.), The portable Oscar Wilde. New York: Penguin Books. (Original work published 1891)

Williams, G. (1983). Not for export: Toward a political economy of Canada's arrested industrialization. Toronto: McClelland and Stewart. 
Williams, G. (1988). On determining Canada's location within the international political economy. Studies in Political Economy, 25.

Williams, G. (1994). Not for export: The international competitiveness of Canadian manufacturing. Toronto: McClelland \& Stewart.

Willoughby, J. (1995). Evaluating the Leninist theory of Imperialism. Science \& Society, 59(3), 320-338.

Wilson, K. G. (2000). Deregulating telecommunications: U.S. and Canadian telecommunications, 1840-1997. Lanham, MD: Rowman \& Littlefield.

Wimmer, A., \& Feinstein, Y. (2010). The rise of the nation-state across the world, 1816 to 2001. American Sociological Review, 75(5), 764-790.

Wingrove, J. (2014, January 27). Ottawa to revise foreign-worker rules as employers complain of delays. The Globe and Mail. Retrieved November 18, 2016, from http://www.theglobeandmail.com/news/politics/ottawa-to-revise-foreign-workerrules-as-employers-complain-of-delays/article16510288/

Winters, J. A. (2011). Oligarchy. New York: Cambridge University Press.

Wolf, E. R. (1982). Europe and the people without history. Berkeley: University of California Press.

Wood, E. M. (1998). Capitalist change and generational shifts. Monthly Review. Retrieved from http://monthlyreview.org/1998/10/01/capitalist-change-andgenerational-shifts/ 
Wood, E. M. (1999). Unhappy families: Global capitalism in a world of nation-states. Monthly Review, 51(3). Retrieved from https://monthlyreview.org/1999/07/01/ unhappy-families/

Wood, E. M. (2002a). Global capital, national states. In M. Rupert \& H. Smith (Eds.), Historical materialism and globalization. London: Routledge.

Wood, E. M. (2002b). Infinite War. Historical Materialism, 10(1), 7-27.

Wood, E. M. (2002c). The origin of capitalism: A longer view. New York: Verso.

Wood, E. M. (2003). Empire of capital. New York: Verso.

Wood, E. M. (2007). A reply to critics. Historical Materialism, 15(3), 143-170.

Woodcock, G. (1989). A social history of Canada. Markham, ON: Penguin Books.

Young, K., Banerjee, T., \& Schwartz, M. (2017, February 3). When capitalists go on strike. Jacobin. Retrieved from https://www.jacobinmag.com/2017/02/capitalstrike-regulations-lending-productivity-economy-banks-bailout/

Žižek, S. (2012, April 24). Occupy Wall Street: What is to be done next? The Guardian. Retrieved from http://www.theguardian.com/commentisfree/cifamerica/2012/apr/ 24/occupy-wall-street-what-is-to-be-done-next 